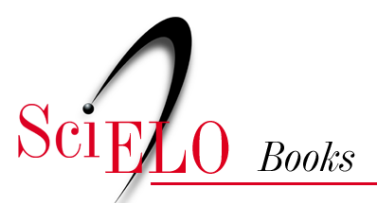

\title{
Identidades emergentes, genética e saúde perspectivas antropológicas
}

\author{
Ricardo Ventura Santos \\ Sahra Gibbon \\ Jane Beltrão \\ (orgs.)
}

SANTOS, R.V., GIBBON, S., and BILTRÃO, J. comps. Identidades emergentes, genética e saúde: perspectivas antropológicas [online]. Rio de Janeiro: Garamond; Editora FIOCRUZ, 2012, 271 p. ISBN: 978-85-7541-518-4. https://doi.org/10.7476/9788575415184.

\section{International license.}

Todo o conteúdo deste trabalho, exceto quando houver ressalva, é publicado sob a licença Creative Commons Atribição 4.0. 


\section{Identidades Emergentes, Genética e Saude Perspectivas antropológicas}


Garamond

UNIVERBITAHIA

Coordenação

Maria Alzira Brum Lemos

CONSELHO EDITORIAL

Bertha K. Becker

Candido Mendes

Cristovam Buarque

Ignacy Sachs

Jurandir Freire Costa

Ladislau Dowbor

Pierre Salama

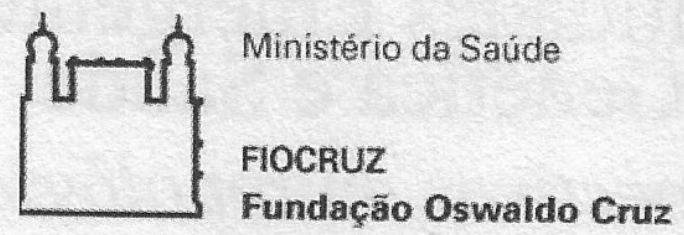

Presidente

Paulo Gadelha

Vice-Presidente de Ensino, Informação e Comunicação

Nisia Trindade Lima

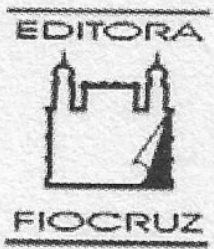

DiRETORA

Nisia Trindade Lima

EDITOR EXECUTIVO

João Carlos Canossa Mendes

Editores Científicos

Gilberto Hochman e Ricardo Ventura Santos

Conselho EdTorial

Ana Lúcia Teles Rabello

Armando de Oliveira Schubach

Carlos E. A. Coimbra Jr.

Gerson Oliveira Penna

Joseli Lannes Vieira

Ligia Vieira da Silva

Maria Cecilia de Souza Minayo 
Organizadores

Ricardo Ventura Santos

Sahra Gibbon

Jane Beltrão

\section{Identidades Emergentes, Genética e Saude Perspectivas antropológicas}


Direitos cedidos para esta edição:

\title{
Fundação Oswaldo Cruz/Editora Editora Garamond Ltda.
}

\author{
Diagramação \\ Luiz Oliveira \\ Capa \\ Estúdio Garamond \\ Revisão \\ Carmem Cacciacarro
}

\author{
Editora Fiocruz \\ Av. Brasil, 4036 - 1ㅇ andar - sala 112 \\ 21040-361 - Rio de Janeiro - RJ \\ Tels: (21) 3882-9039 e 3882-9041 \\ Fax: (21) 3882-9007 \\ e-mail: editora@fiocruz.br \\ http://www.fiocruz.br/editora
}

\section{Editora Garamond Ltda.}

Caixa Postal 16.230

22.222-970 - Rio de Janeiro - RJ

Tel: (21) 2504-9211

e-mail:editora@garamond.com.br

http://www.garamond.com.br

\section{CIP-BRASIL. CATALOGAÇÃO NA FONTE \\ SINDICATO NACIONAL DOS EDITORES DE LIVROS, RJ.}

\section{I22}

Identidades emergentes, genética e saúde : perspectivas antropológicas / organizadores, Ricardo Ventura Santos, Sahra Gibbon, Jane Beltrão. - Rio de Janeiro : Garamond; Rio de Janeiro : Editora Fiocruz, 2012.

272 p. $14: 21 \mathrm{~cm}$

ISBN 978-85-7617-257-4

ISBN 978-85-7541-297-8

1. Antropologia. I. Santos, Ricardo V. (Ricardo Ventura), 1964-. II. Gibbon, Sahra. III. Beltrão, Jane Felipe.

12-2907.

Todos os direitos reservados. A reprodução não-autorizada desta publicação, por qualquer meio, seja total ou parcial, constitui violação da Lei nº 9.610/98. 


\section{SUMÁRIO}

\section{Apresentação}

Ricardo Ventura Santos, Sahra Gibbon e Jane Felipe Beltrão

\section{Parte I: Saúde, genética e sociedade:}

\section{novas/velhas questões, novas/velhas configurações}

Degeneração e eugenia na história da psiquiatria moderna

Sandra Caponi

"Agressividade" e "violência": a difícil tarefa de conceituar no

diálogo entre geneticistas e cientistas sociais

Gláucia Silva

Saúde, longevidade e genética: um olhar biopolítico

Luis David Castiel.

Parte II: Reprodução, molecularização e biopolítica da vida em si

Doação de sêmen e classificação étnico-racial no Brasil

Rosely Gomes Costa

Identidade genética no debate sobre o estatuto de fetos e embriões

Naara Luna

A "molecularização" do câncer de próstata:

reflexões sobre o chip de DNA

Marko Monteiro, Ricardo Z. N. Vêncio

\section{Parte III: Tecnologias genéticas e identidades} étnico-raciais emergentes

Usos políticos da leucopenia e diferença racial no Brasil contemporâneo Elena Calvo-Gonzáles 
A importância de ser uro: movimentos indígenas, políticas

de identidade e pesquisa genética nos Andes peruanos

Michael Kent

Biorrevelações: testes de ancestralidade genética

em perspectiva antropológica comparada

Verlan Valle Gaspar Neto, Ricardo Ventura Santos, Michael Kent ...... 233

Sobre os autores

269 


\section{APRESENTAÇÃo}

Ricardo Ventura Santos, Sahra Gibbon e Jane Felipe Beltrão

Alguns anos atrás, em 2007, um jornal de Salvador, Bahia, publicou uma criativa charge do artista e cartunista Cau Gomez. Esta charge foi simultaneamente inspirada no conhecido desenho "homem vitruviano", do artista renascentista italiano Leonardo da Vinci, e nos debates sobre raça, genética e ancestralidade que se tornaram frequentes no Brasil ao longo de toda a primeira década do século XXI. ${ }^{1}$ Como em outros países do mundo, a partir da aplicação de sofisticadas tecnologias genômicas, têm ocorrido discussões acerca de aspectos da história da formação da sociedade brasileira e da construção da sua identidade. Como veremos ao longo deste livro, esses debates, que em muito transcendem as fronteiras dos laboratórios, interagem com percepções e discursos sociais mais amplos, além de influenciarem práticas com consequências as mais diversas.

Se o homem concebido por da Vinci é um cânone da beleza clássica, com proporções perfeitas entre as diversas partes do corpo, na versão brasileira, concebida por Cau Gomez, o que está em jogo não são somente as relações geométricas do corpo humano. Com o título "composição genética (o DNA do povo brasileiro)", o foco está, ao contrário da proporcionalidade perfeita de Vinci, nas "imperfeições" de um corpo que, para utilizar uma expressão de grande peso histórico, é quase "degenerado". As partes do corpo deste "homem vitruviano brasileiro" são desproporcionais, como se resultando de más condições de saúde, incluindo sequelas de desnutrição, tuberculose,

1 Gostaríamos de agradecer a Elena Calvo-Gonzáles, que foi quem primeiro chamou nossa atenção para a charge de Cau Gomez. 
verminose e raquitismo: cabeça desproporcionalmente grande, um peito no qual se veem as marcas das costelas sob a pele, uma barriga volumosa talvez devido à infecção por vermes e pernas finas e secas. A mensagem é a de que os genes (ou a biologia, de uma maneira geral) não explicam a totalidade e a complexidade do que é esse ser humano: as porcentagens de ancestralidade genético-geográfica, por si, não atingem os $100 \%$, somente lá chegando quando somadas à fome, ao desemprego e ao analfabetismo.

Mais africano que europeu, com algumas pitadas de genes ameríndios, o "homem vitruaniano brasileiro" é um mestiço, com uma "composição genética" eminentemente biossocial, incluindo simultaneamente ancestralidade biológica e um "DNA socioeconômico-político". Seria difícil localizar uma imagem mais apropriada que aquela concebida por Cau Gomez para abrir este livro. É uma alegoria que remete a alguns dos debates mais candentes no campo da biopolítica no início do século XXI, no Brasil e no mundo.

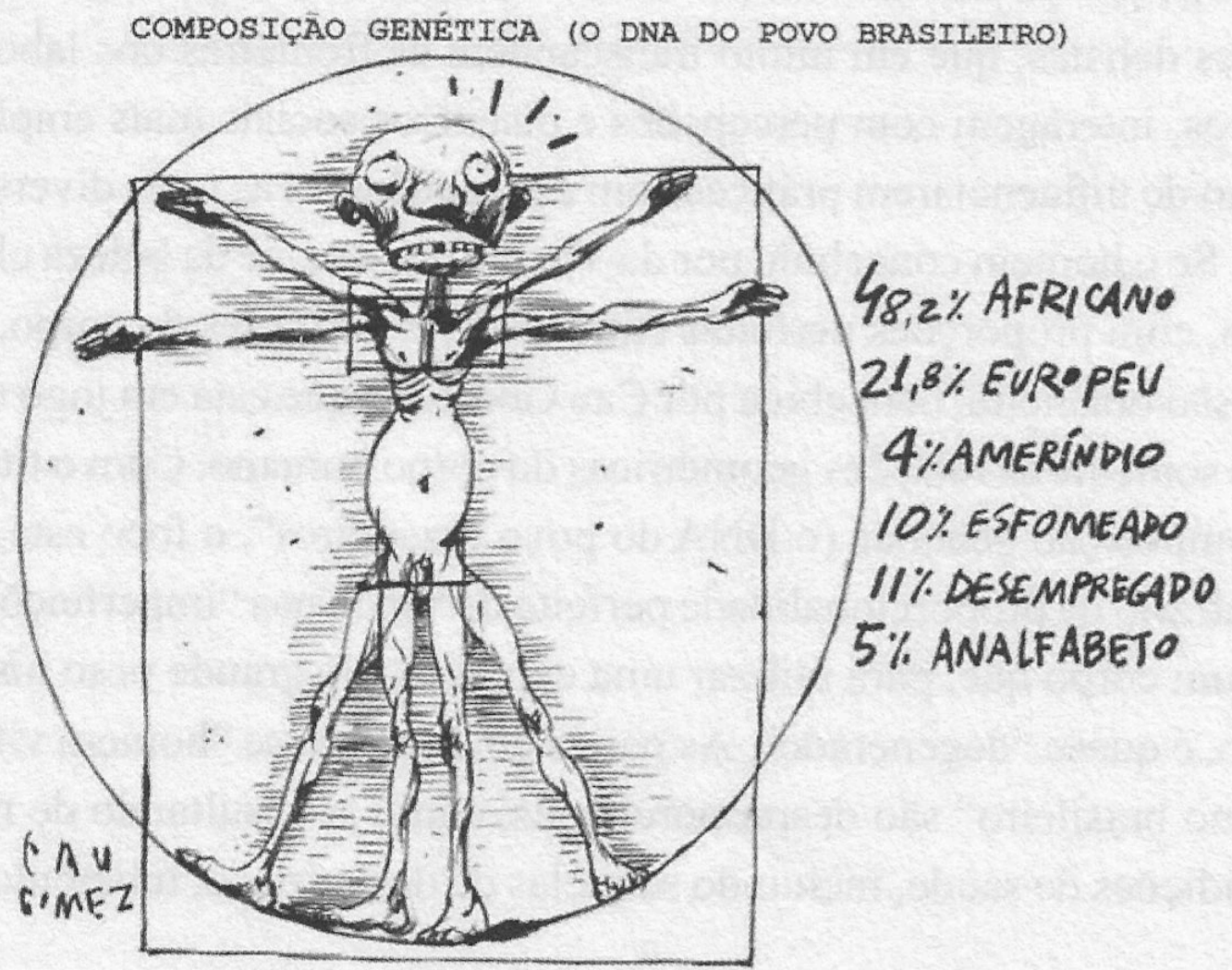

Figura 1. Charge "Composição genética (o DNA do povo brasileiro)", de autoria de Cau Gomez (reproduzida com permissão). 
De um ponto de vista teórico mais amplo, há um crescente interesse por parte das ciências humanas e sociais no que Rose (2007) e outros têm denominado como "política da vida em si" ou "as formas emergentes de vida" (ver também Fischer, 2003; Franklin, 2002; Gibbon \& Novas, 2008; Lock, 2002; Inda, 2005; Pálsson, 2007; Wade, 2002 , entre outros). Um aspecto central nessas discussões é analisar como as novas tecnologias biológicas estão reconfigurando (ou não) as noções de humano, assim como as implicações socioculturais, políticas e éticas decorrentes dessas transformações. As possibilidades contemporâneas de "engenharia dos processos vitais", que incluem a aplicação de técnicas em áreas tão diversas (e ao mesmo tempo afins) como sequenciamento genômico (incluindo testes de ancestralidade), células-tronco, tecnologias reprodutivas (com foco em gametas e embriões), fabricação e regeneração de órgãos in vitro, desenvolvimento de novos fármacos (em particular no campo da psiquiatria), entre outros, estariam moldando "novas práticas de vida". Inda (2005: 14) comenta que, no presente, as possibilidades de aplicação tecnológica fazem com que a ciência se torne, crescentemente, "não somente contemplação, mas prática e intervencionista". Para vários analistas, o aumento exponencial nas possibilidades de intervenção sobre processos vitais a nível molecular está fazendo com que, em uma escala talvez sem precedentes na história, a vida humana esteja se tornando passível de inesperadas e surpreendentes reformulações.

A partir de uma posição de ceticismo, poder-se-ia indagar: será que os atuais debates sobre as "políticas da vida" envolvem dimensões tão radicalmente novas que, de fato, representariam descontinuidades com trajetórias pregressas? Inspirado na perspectiva foucaultiana, Rose (2007: 5) situa o que denomina de "cartografias do presente" como parte de processos de "continuidades ao mesmo tempo que de mudanças". Para esse autor, ainda que o que experimentamos hoje em termos de usos e implicações do conhecimento biológico se insira em processos de longa duração, há indícios de que os processos atuais 
envolvem transformações qualitativas (ou de escala) que não devem ser desconsideradas (ver também Atkinson, Glasner \& Lock, 2009; Fischer, 2003; Franklin, 2002; Gibbon \& Novas, 2008; Lock, 2002; Inda, 2005; Pálsson, 2007; Wade, 2002, entre outros).

Gerações de historiadores, filósofos, antropólogos e sociológicos têm produzido vasta documentação sobre as formas de controle, manejo e intervenção sobre as capacidades vitais dos seres humanos. Ao longo dos séculos, tais processos têm se manifestado, por exemplo, em diversas "práticas de governança" da vida, como exemplificado pelo manejo das questões demográficas (nascimento, vida e morte) e de saúde pública por parte dos governos. Para os estudiosos da biopolítica contemporânea, se há algo novo no horizonte, é a combinação entre aumento da capacidade de intervenção (decorrente das transformações técnico-científicas), associada a um crescente foco no âmbito individual. No atual século biotecnológico, conforme indica Rose (2007: 253), “diversos aspectos de nossa vitalidade humana já se tornaram tecnificados, e assim abertos para manipulação e modificação". Assim, somando-se às práticas biopolíticas centradas nas coletividades (com seus recortes de gênero, idade, classe, raça, nacionalidade etc.), a tecnociência trouxe para a arena da vida cotidiana, de uma maneira possivelmente sem precedentes, o foco nos indivíduos. Dentre as múltiplas maneiras, isso se manifesta na possibilidade de seleção de características genéticas de óvulos e embriões (o que seria uma das novas faces da eugenia - ver Taussig, Rapp \& Heath, 2003), na reconfiguração dos corpos através de transplantes e das terapias gênicas, na produção de novas genealogias individuais e coletivas (como a inserção de indivíduos na macro-história evolutiva humana através dos testes de ancestralidade genômica), e assim por diante.

Visando compreender a modernidade como um momento "no cruzamento de múltiplas histórias” (p. 5), Rose destaca cinco dimensões que, em sua visão, marcam a biopolítica contemporânea (p. 5-7; 
ver também, p. 9-40). A primeira vertente diz respeito à crescente molecularização dos loci de conhecimento e intervenção, o que se manifesta de forma contundente na disseminação de tecnologias de manipulação do DNA e em todas suas implicações socioculturais, políticas e éticas. A segunda é o que o autor chama de "otimização", isto é, nos dias atuais, as tecnologias de intervenção nos processos vitais potencializam outras situações que não somente, por exemplo, os extremos da saúde e da doença (ou do normal e do patológico). Assim, a tecnociência biomédica contemporânea tem o potencial de produzir "pacientes em espera", isto é, ainda que não clinicamente enfermos, a identificação de predisposições genéticas, por exemplo, tornam sujeitos "doentes por antecipação". O terceiro aspecto é o da intensa produção de processos de "subjetivação". Esse ponto, que ressoa perspectivas como a de biossocialidade de Paul Rabinow (ver Rabinow, 1992; também Gibbon \& Novas, 2008) ou de "cidadania genética" de Heath, Rapp e Taussig (2007), diz respeito à emergência de padrões de relações socioculturais a partir da capilarização, na sociedade, dos empregos das tecnologias biológicas. O quarto ponto se relaciona à proliferação de arranjos profissionais e institucionais vinculados à governança das "políticas da vida". Tal aspecto envolve não somente uma crescente complexificação de especialidades profissionais voltadas para a produção e aplicação do conhecimento biológico, como também a crescente diversificação dos aparatos de regulação (comitês de ética, por exemplo). O quinto e último aspecto vincula-se à dimensão de mercado, que Rose chama de "economias da vitalidade". As imbricações entre tecnologias biológicas, biopolítica e mercado constituem um recorte de crescente interesse por parte dos analistas, como é o caso da noção de "biocapital", proposta por Rajan (2006).

\section{***}

Esta coletânea reúne um conjunto de trabalhos que, através de diferentes focos de análise e de perspectivas teórico-conceituais, 
se debruça sobre questões da biopolítica contemporânea, sobretudo com foco no Brasil. As contribuições foram originalmente apresentadas em um seminário realizado nos dias 31 de junho e 1 de julho de 2010, em Belém, como atividade associada à $27^{\text {a }}$. Reunião da Associação Brasileira de Antropologia, em Belém, Pará. O evento reuniu antropólogos, historiadores, geneticistas e pesquisadores da área da saúde coletiva e partiu do reconhecimento de que a complexa problemática decorrente das biopolíticas requer crescente esforço reflexivo, em particular aqueles de ordem multi e interdisciplinar.

Como exporemos mais detalhadamente adiante, os textos aqui reunidos estão em sua totalidade voltados para as vinculações entre produção de conhecimento científico sobre a biologia humana e seus desdobramentos socioculturais e políticos. Mas, antes de apresentarmos os capítulos especificamente, cabe uma breve contextualização sobre uma arena específica que é o foco de interesse de um expressivo conjunto de colaboradores deste livro (e que também foi o tema central do seminário que resultou nesta coletânea). Estamos nos referindo às interfaces entre raça, saúde/doença e tecnologias genéticas emergentes.

\section{$* * *$}

Vejamos duas afirmações que são, no mínimo, contundentes, extraídas de livros recentes que, com foco em estudos sociais da ciência e antropologia, abordam as interfaces entre raça e genética no mundo contemporâneo. A primeira, do livro Revisiting race in a genomic age, é a seguinte: "ao contrário... de expectativas e esperanças, a ciência pós-genômica tem revivido a noção de categoria racial como indicativa de diferenças biológicas" (Koenig, Lee \& Richardson, 2008: xx); na segunda, do livro What's the use of race? Modern governance and the biology of difference, lê-se: "o que é inesperado é a maneira como raça tem sido revigorada como categoria social, legal e médica pela ciência, em particular 
pela genética" (Whitmarsh \& Jones, 2010: 2, ver também Abu El-Haj, 2007). ${ }^{2}$

Tomando os dois volumes acima mencionados como referência, as novas perspectivas sobre raça no contexto das tecnologias genéticas emergentes têm se concentrado em um diversificado conjunto de temas. Em uma vertente que ressoa os interesses de reflexão sobre a "política da vida em si" (Rose, 2007), as formas através das quais raça tem sido ser utilizada para fins de governança constituem o foco da coletânea de Whitmarsh e Jones (2010). Enfatizando tanto "promessas" como "perigos" envolvidos, os organizadores analisam as formas como raça e genética, no presente, têm sido incorporadas em três esferas (regulamentação, conhecimento e cuidado). Torna-se evidente que velhas e recentes categorias, práticas políticas e instituições adquirem novas ênfases e significados no contexto de emergência das atuais tecnologias genéticas. Koenig, Lee e Richardson (2008), por sua vez, identificam quatro temas que, segundo as autoras, refletiriam as especificidades e configurações atuais das interfaces entre raça e genética na contemporaneidade.

O primeiro tema destacado por Koenig, Lee e Richardson (2008) se relaciona à conclusão do sequenciamento do genoma humano nos primeiros anos do século XXI. Tal marco tem sido apontado como o início da "era genômica", em particular, por estabelecer uma mudança desde pesquisas relativamente concentradas na identificação de genes particulares ("gene hunting") para análises enfocando o genoma como um todo. Nesse âmbito, a despeito dos antigos e longos debates sobre a aplicabilidade do conceito de raça para descrever a variabilidade biológica humana (Duster, 2005; REGWG, 2005), raça e ancestralidade se tornaram aspectos centrais na pesquisa genômica contemporânea (Bolnick, 2008; Nelson, 2008; Pállson, 2007; Santos

2 Além dessas coletâneas, há diversos outros trabalhos recentes que analisam o que tem sido chamado de "reinscrições", assim como suas variações, de raça na era da genômica (ver, entre outros, Abu El-Haj, 2007; Bliss, 2009; Browdin, 2005; Fujimura, Duster \& Rajagopalan, 2008; Fujimura \& Rajagopalan, 2011; Krimsy \& Sloan, 2011, entre outros). 
et al., 2009). Com muitas (e talvez infinitas) vidas, e ao contrário dos prognósticos a partir do pós-II Guerra Mundial, raça permanece viva e vivaz mesmo após o sequenciamento do genoma humano, quando se revelou que as diferenças entre as populações, do ponto de vista do DNA, são ínfimas (para essa discussão no caso brasileiro, ver, entre outros, Maio \& Santos, 2010).

O segundo tema diz respeito às maneiras como raça e tecnologias genéticas estão entrando no mercado. ${ }^{3}$ Esse aspecto talvez tenha sua maior expressão nos investimentos comerciais feitos no campo da farmacogenômica (Ashcroft, 2006; Fullwiley, 2007; Suarez-Kurtz, 2005) e na expansão no número de empresas que oferecem testes genéticos para averiguar a ancestralidade biológica das pessoas (Bolnick, 2008; Nelson, 2008).

Estreitamente vinculado ao tema acima, está o terceiro destacado por Koenig, Lee e Richardson (2008), qual seja, a estreita associação entre raça, novas tecnologias genéticas e políticas de identidade. ${ }^{4}$ No campo da farmacogenômica, um dos debates de destaque é aquele do desenvolvimento de medicamentos voltados para segmentos étnico-raciais específicos, como é o caso do medicamento Bidil, o primeiro voltado para "afro-americanos" a ser aprovado pela agência de regulamentação sanitária norte-americana (Fullwiley, 2007; Kahn, 2005; Suarez-Kurtz, 2005). No caso dos testes genéticos voltados para ancestralidade, tem havido uma proliferação destes nos últimos anos, os quais têm como público-alvo segmentos sociais os mais diversos, mas com destaque para afro-americanos, populações indígenas e judeus (Bolnick, 2008; Nelson, 2008; Maio \& Santos, 2010).

Finalmente, o quarto tema destacado por Koenig, Lee e Richardson (2008) é o de que as pesquisas genéticas atuais tendem, de forma crescente, a se concentrar em contextos médicos que abordam grupos

3 Esse ponto se remete diretamente à perspectiva da "economia da vitalidade" de Rose (2007).

4 Ver comentário anterior sobre os "processos de subjetivação" em Rose (2007). 
populacionais específicos. Se no âmbito individual há a ênfase na "medicina personalizada", que levaria em consideração o perfil genético dos indivíduos, em uma escala mais ampla a pesquisa genética passa a se ocupar crescentemente, sobretudo nos EUA, de grupos como os afro-americanos e latinos, apenas para citar dois exemplos (Kittles \& Weiss, 2003; Montoya, 2011).

Tanto os volumes editados por Koenig, Lee e Richardson (2008) como Whitmarsh \& Jones (2010) enfocam, sobretudo, estudos de caso referentes aos contextos norte-americanos e europeus. Uma indagação pertinente é como se colocam os mesmos conjuntos de questões na interface entre produção de identidades sociais (e raciais especificamente) e tecnologias genéticas emergentes em outros contextos históricos e sociopolíticos.

$\mathrm{Na}$ Introdução de seu conhecido livro sobre a história da eugenia na América Latina, Nancy Stepan (1991) analisa por que, até a década de 1980, havia poucas investigações voltadas para a América Latina. Segundo ela, nas correntes historiográficas da época predominava uma perspectiva de desinteresse pelo tema, percebido "como não mais que pálido reflexo do pensamento europeu” (p. 10). Se para os contextos norte-americanos e europeus havia uma rica e vibrante literatura em história da ciência sobre a eugenia, segundo ela, "a premissa implícita é que os estudiosos que se dedicam à história intelectual da América Latina analisam uma tentativa de imitar ou reproduzir uma atividade européia em um contexto estranho e não científico" (p. 10-11).

Desde que foi publicado, no início da década de 1990, The hour of eugenics teve um importante papel na redefinição dos estudos históricos e antropológicos sobre a eugenia na América Latina. As análises de Stepan sobre a trajetória da eugenia no México, Brasil e Argentina estimularam novas gerações de pesquisadores a se dedicarem ao tema na região (ver, por exemplo, Hochman, Lima \& Maio, 2010). O que vem sendo demonstrado é que, embora tenha 
sido lugar-comum no pensamento ocidental, os historiadores têm destacado também que a história da eugenia não pode ser apreendida como um conhecimento científico homogêneo e unitário, definido a partir de interesses e objetivos comuns. Estudos comparativos sobre a história da eugenia apontam para uma diversidade de ideias e para a implantação de diferentes políticas eugênicas. Conforme destaca o historiador Mark Adams (1990: 226), a eugenia foi um movimento de ideias que se reconfigurou de acordo com os diferentes contextos nacionais, conformados pelas tradições culturais específicas de cada região do mundo.

Excelentes trabalhos, como os já citados volumes editados por Koenig, Lee e Richardson (2008) e Whitmarsh e Jones (2010), trazem importantes análises sobre as atuais configurações e interfaces de raça no âmbito da ciência genômica contemporânea. Os focos de ambos os livros estão em contextos históricos, geográficos, culturais e políticos particulares, sobretudo América do Norte e Europa. À semelhança da trajetória percorrida pelos estudos sobre história da eugenia, nos quais os olhares sobre outros contextos ajudaram a melhor compreender o panorama global, através dos textos desta coletânea, com sua ênfase no caso brasileiro, almeja-se contribuir com os debates sobre as dimensões socioculturais e políticas atreladas à produção de conhecimento sobre as coletividades humanas através da aplicação das tecnologias genéticas. Os trabalhos configuram, em seu conjunto, uma janela que permite melhor compreender alguns dos principais contextos históricos, sociais e políticos no âmbito dos quais estão se desenvolvendo os debates em torno da genética, cultura e sociedade no Brasil de hoje. Se a concepção da genômica atual enquanto uma ciência global que envolve complexas articulações transnacionais ao longo de cadeia de produção do conhecimento técnico-científico (Ong \& Collier, 2005) é algo inquestionável, é também evidente que tais dinâmicas interagem com parâmetros culturais e políticos locais que são historicamente definidos. No caso brasileiro, por exemplo, de 
maneira mais próxima ou distante, os debates sobre o perfil genômico da população, como os leitores terão oportunidade de ver, passam, necessariamente, pela questão racial e pelo tema da mestiçagem em particular (ver Maio \& Santos, 2010).

$* * *$

Os capítulos desta coletânea estão organizados em três seções. Através de diferentes enfoques, os textos abordam as múltiplas formas pelas quais a ciência (em especial a tecnociência contemporânea) contribui para moldar o mundo social em domínios como identificação pessoal, identidades nacionais e ações coletivas, inclusive na área da saúde. Além disso, os autores apresentam análises acerca de como a sociedade questiona e se envolve com as emergentes conceitualizações, sobretudo de ordem identitária (cor, raça, etnia), derivadas do conhecimento e das práticas engendradas pela ciência.

A primeira parte, intitulada "Saúde, genética e sociedade: novas/ velhas questões, novas/velhas configurações" reúne três capítulos, de autoria de Sandra Caponi, Glaucia Silva e Luis David Castiel.

Com um enfoque histórico no campo da psiquiatria, Sandra Caponi analisa as transformações sofridas pelo conceito de degeneração e sua vinculação com as estratégias eugênicas iniciadas nas últimas décadas do século XIX e nas primeiras do XX. Seu ponto de partida é uma análise do Tratado de degeneração física, moral e mental, de Morel, publicado em 1857. A autora enfatiza que, se degeneracionistas e eugenistas compartilhavam um interesse por identificar as características físicas e comportamentais consideradas indesejáveis, havia diferenças significativas nas abordagens e nas intervenções preconizadas, o que incluiu uma maior ênfase não somente na dimensão da hereditariedade como também da raça, no caso dos eugenistas. Estabelecendo pontes com o presente, Caponi afirma que, "sem pretender negar as profundas transformações introduzidas na percepção e na gestão dos fatos psíquicos e sociais nos anos posteriores à Segunda Guerra Mundial", a ciência contemporânea 
continua a compartilhar com os precursores da psiquiatria a busca por "explicações neurogenéticas precisas para cada um de nossos comportamentos, aflições e sofrimentos".

Gláucia Silva aborda em seu texto um debate travado entre a biologia e as ciências sociais no Brasil, mais especificamente entre o geneticista Renato Flores (da Universidade Federal do Rio Grande do Sul) e a socióloga Maria Cecília Minayo (da Fundação Oswaldo Cruz) em torno de um tema de grande relevância para a sociedade brasileira, qual seja, os fatores envolvidos naa gênese e na expressão da agressividade/delinquência/violência. Enquanto Flores situa os determinantes últimos desses fenômenos na dimensão evolutivo-biológica, a ênfase de Minayo está em questões sociopolíticas contemporâneas. Se Caponi parte de um contexto histórico e tece uma narrativa que chega ao presente, de certo modo Silva percorre um caminho inverso: toma um estudo de caso contemporâneo e, através de sua argumentação, mostra suas íntimas vinculações com contextos históricos e epistemológicos de longa duração. Apontando para as necessidades e dificuldades conceituais e argumentativas envolvidas no diálogo entre diferentes áreas do conhecimento, a autora mostra como as alegações biológicas contemporâneas sobre violência podem ser situadas na extensa trajetória de debates sobre a dicotomia natureza/cultura, tão cara ao desenvolvimento da antropologia.

Fechando o primeiro bloco, Luis David Castiel também aborda as imbricações entre ciência, cultura e sociedade, debruçando-se sobre outra categoria de "predisposição", qual seja, a longevidade da vida humana. Assim como os dois primeiros capítulos, sua análise enfoca como um processo eminentemente complexo, decorrente de múltiplas interfaces entre biologia e dimensões individuais e coletivas no plano sociocultural, não somente se torna "biologizado" pela tecnociência, como também passível de intervenção. Inspirando-se no conceito de biopoder, de Foucault, Castiel propõe o de epidemiopoder, o qual, 
segundo ele, "consistiria em idiomas/vocabulários e aspectos morais sustentados pelos conhecimentos produzidos pela epidemiologia enquanto um dispositivo de técnicas e práticas de investigação cujos resultados 'revelam' as condições de saúde (riscos e agravos) de grupos humanos". Explicitamente lançando mão das proposições de Rose (2007), e mostrando o papel das tecnologias modernas de comunicação (como a internet), o autor argumenta que o "epidemiopoder" está associado a dimensões como molecularização, bioeconomia e o desenvolvimento de novas comunidades de especialistas.

A segunda seção, denominada "Reprodução, molecularização e biopolítica da vida em si", reúne três capítulos, de autoria de Rosely Gomes da Costa, Naara Luna e, em parceria, Marko Monteiro e Ricardo Vêncio.

$\mathrm{Na}$ interface entre os campos da bioética e da socioantropologia das relações raciais no Brasil, o texto de Rosely Costa ${ }^{5}$ centra-se no tema da doação de sêmen. A autora analisa as tensões decorrentes do fato de que a legislação brasileira determina que o doador deve permanecer anônimo, ao mesmo tempo em que há interesse, por parte dos casais que buscam inseminação artificial, em conhecer suas características. Nesse processo, equipes médicas passam a ser intermediários no que diz respeito aos critérios de classificação racial. Os dados apresentados por Costa, que se baseiam em pesquisa etnográfica realizada em clínicas de reprodução em Campinas, no Estado de São Paulo, não somente explicitam as questões ligadas ao uso de tecnologias reprodutivas, tema que tem sido central na literatura sobre biopolíticas, como também nos mostra os complexos processos de subjetivação envolvidos na caracterização dos doadores de sêmen, incluindo atributos físicos e comportamentais. O texto deixa evidente que a aplicação de tecnologias reprodutivas precisa ser compreendida à luz de contextos socioculturais particulares os quais,

5 No final de 2011, quando estávamos redigindo esta Apresentação, recebemos a triste notícia do falecimento de nossa colega Rosely Costa, ocorrido em 4 de dezembro de 2011. 
no caso analisado, envolvem, em larga medida, questões associadas à dimensão étnico-racial brasileira.

O capítulo de Naara Luna explora o debate público sobre o estatuto de fetos e embriões no tocante ao uso de argumentos fundamentados em dados genéticos para descrever a condição desses entes, e em particular como a genética é acionada tanto para fundamentar posições pró-vida quanto para descartá-las. Além da questão mais direta da reprodução, o trabalho de Luna compartilha com o de Gomes o interesse em analisar como o conhecimento científico alcança a sociedade, o que ocorre através dos discursos de especialistas e de intervenções de representantes de movimentos sociais. A partir de uma perspectiva etnográfica, a pesquisa de Luna centra-se em dados coletados a partir de audiências públicas com especialistas, convocadas pelo Supremo Tribunal Federal (STF), para discutir um "conceito operacional jurídico para vida humana". Como nos mostra a autora, independente da posição defendida, os diversos atores engajados nas discussões abordam, em suas intervenções, questões ligadas a identidades, mais especificamente ao que se entende como início da vida. Luna mostra ainda como em debates públicos as tecnologias biológicas podem ajudar a reforçar a "genetização do ser humano e das relações familiares".

Tomando como estudo de caso as aplicações de uma tecnologia de ponta (biomarcadores moleculares para o câncer de próstata), o texto de Marko Monteiro e Ricardo Vêncio é uma análise acerca de como as práticas científicas contemporâneas vêm produzindo uma "molecularização" da vida e do corpo a partir de uma diversidade de perspectivas. O interesse dos autores está em refletir sobre mudanças nas formas como o câncer de próstata vem sendo classificado, ou seja, a passagem de um momento em que as descrições eram originalmente baseadas na anátomo-patologia e fisiologia, para outro no qual há o predomínio de características moleculares ou genéticas, além de envolver processos de digita- 
lização do corpo. Conforme indicado por Monteiro \& Vêncio, no caso em apreço, o conceito de representação finda por não descrever "adequadamente as emergentes formas moleculares de definição de doenças, pois, nesse caso, os mesmos conceitos que são usados para 'representar' aspectos do corpo transformam-se em formas de manipular e interferir nesse mesmo corpo". Ao enfocar a questão da "molecularização", tanto no âmbito da descrição científica quanto da manipulação da matéria, os autores abordam um tema central da biopolítica no início do século XXI.

A terceira parte do volume tem como título "Tecnologias genéticas e identidades étnico-raciais emergentes" e traz três contribuições, de autoria de Elena Calvo-Gonzáles, Michael Kent e, em parceria, Verlan Valle Gaspar Neto, Ricardo Ventura Santos e Michael Kent.

Tendo como pano de fundo a dimensão étnico-racial, Elena Calvo-Gonzáles analisa os discursos relacionados a uma condição denominada leucopenia (baixa contagem de leucócitos no sangue) no contexto da luta sindicalista e das discussões contemporâneas sobre a chamada "saúde da população negra". A autora compara perspectivas sobre como diferenças inscritas nos corpos são reinterpretadas com base em transformações do contexto sociopolítico brasileiro. Além de se remeter ao fundamental debate sobre a qualidade híbrida do conceito de raça, Elena Calvo-Gonzáles dialoga com a literatura contemporânea sobre raça e saúde, que tem na anemia falciforme um caso emblemático de discussão sobre a saúde da população negra, tanto no Brasil como nos Estados Unidos. Se, por um lado, a leucopenia foi e, em alguns contextos, continua a ser vista como condição "natural" associada a características biológicas do corpo negro, em outros não o é. A análise, como coloca a autora, "nos remete a noções sobre desigualdade e posição social que não necessariamente concebem a diferença em termos biológicos". Os argumentos desenvolvidos no texto mostram as íntimas vinculações entre identidades étnico-raciais, conhecimento genético, saúde e políticas públicas. 
O texto de Michael Kent analisa, com base em um estudo de caso sobre o povo indígena Uro, dos Andes bolivianos, como a genética tem sido acionada em debates correntes sobre identidade étnica diferenciada, com expressivas implicações sobre a dinâmica dos movimentos sociais indígenas. Como indica o próprio Kent, seu intuito é "contribuir para um entendimento maior das condições sociais que possam levar à aceitação ou rejeição desse tipo de pesquisa por parte das populações que constituem seu objeto". A partir de informações etno-históricas, pesquisa etnográfica nos Andes bolivianos e análise da literatura científica sobre genética dos Uro, o autor mostra que, a depender do contexto, explicações baseadas em ancestralidade genética podem vir a ser acionadas em políticas de identidade e em lutas políticas pelo reconhecimento de direitos. Trata-se de um tema importante na reflexão da agenda antropológica, uma vez que as tecnologias genéticas podem estimular a produção de identidades essencializadas. Uma dimensão de particular relevância no capítulo de Kent é o fato de que a pesquisa genética sobre os Uros faz parte de iniciativas de abrangência global, no caso o chamado projeto Genográfico, o que aponta para as dimensões transnacionais das investigações sobre a genética dos povos indígenas. ${ }^{6}$

Os complexos processos de ordem social e política envolvidos no que poderíamos chamar de "etnogênese" de identidades coletivas via genética é também o tema do último capítulo da coletânea. O foco do texto de Gaspar Neto, Santos \& Kent está na análise comparativa de três empresas que comercializam teste de ancestralidade genética, African Ancestry, nos EUA, Oxford Ancestors, na Inglaterra,

6 Ainda que o trabalho de Kent diga respeito ao contexto etnográfico andino, as questões que levanta sobre as relações entre pesquisas genéticas e identidades sociais indígenas são extrapoláveis para outros contextos etnográficos, incluindo o brasileiro. O próprio Kent tem realizado investigações em antropologia da ciência no sul do Brasil voltadas para uma melhor compreensão das complexas relações entre pesquisas genéticas, identidades indígenas e movimentos sociais (Kent \& Santos 2012). 
Laboratório GENE, no Brasil. Os autores utilizam as duas empresas estrangeiras como contraponto analítico para a brasileira a fim de avaliar o que as aproxima e distancia no tocante ao trato concedido ao potencial revelador de seus respectivos testes e, também, com que teor questões como pertença étnica/racial perpassam o merchandising de seus produtos e a sua postura pública. Eles argumentam que contextos sociopolíticos específicos influenciam as formas como os testes de ancestralidade genética são apresentados e justificados para seus respectivos públicos de consumidores. Em particular, no caso da empresa brasileira, a questão da miscigenação, tão central no panorama histórico-antropológico mais amplo sobre "raça" e relações raciais, ajuda a compreender como os testes de ancestralidade são justificados e apresentados à sociedade.

\section{***}

As reflexões sobre o que tem sido denominado "formas emergentes de vida", como já tivemos a oportunidade de comentar, tem nas dimensões de continuidade/descontinuidade, tanto no plano epistemológico como da intervenção, uma importante questão de debate. Mencionamos também que, em sua caracterização da "cartografia do presente", Rose (2007: 5) vê o atual "século biotecnológico" como o de "cruzamento de múltiplas histórias". Especificamente sobre a relação entre raça, identidades e genética no Brasil, aqui cabe lembrar um comentário de Luiz Fernando Dias Duarte sobre o que, afinal, constitui a "antropologia na era da genética" (ver Santos \& Maio, 2005). Será que, nos dias atuais, estamos diante de uma situação de novas tecnologias biológicas alimentando, direta ou indiretamente, a emergência de novas configurações ideológicas? Vários capítulos desta coletânea, de diferentes maneiras, sinalizam em suas análises que, menos que uma combinação entre "novas tecnologias biológicas e novas configurações ideológicas", o que persistentemente se insinua no horizonte, parafraseando Duarte, são "novas tecnologias biológicas e velhas configurações ideológicas". 
Em suas análises, os autores aqui reunidos sinalizam que questões e práticas tão diversificadas como eugenia, tecnologias de visualização e reprodução, risco e saúde, etnicidade e identidades sociais e processo saúde/doença experimentam ressignificações através da linguagem e das tecnologias genéticas. Mas tais ressignificações não significam, necessariamente, ruptura - no mais das vezes, o que se nota são continuidades com configurações presentes desde longa data. Ao mesmo tempo em que as continuidades são mais que evidentes, a partir das ricas análises empreendidas neste volume, os leitores poderão identificar algumas diversas dimensões estruturantes da biopolítica contemporânea, cujos contornos não se faziam tão recorrentes. Essas dimensões incluem a ênfase na molecularização, profusa produção de significados socioculturais (subjetivação) a partir das tecnologias genéticas e uma crescente vinculação entre essas tecnologias e o mercado (Rose, 2007; Koenig, Lee \& Richardson, 2008; Whitmarsh \& Jones, 2010).

Temperadas com aspectos locais relacionados a raça, tipologias biológicas, mercado e nacionalismos, os temas tratados nesta coletânea, ao mesmo tempo que adquirem tonalidades (em geral brasileiras) específicas, como a ênfase na miscigenação, certamente transcendem fronteiras nacionais e refletem configurações internacionais de amplo alcance. Essa dupla e íntima vinculação local/transnacional ganha contornos bastante nítidos não somente através do uso da clássica imagem do "homem vitruviano" reconfigurada para o contexto local brasileiro, com a qual abrimos esta apresentação. Manifesta-se também no fato de que, recuperando Rose (2007) e Whitmarsh e Jones (2010), as "reinscrições" moleculares dos processos analisados neste volume envolvem práticas de governança, nos planos da regulamentação, conhecimento e cuidado, desde o âmbito individual ao coletivo (ver também Abu El-Haj, 2007). Essa governança, como nos lembra Koenig, Lee e Richardson (2008), para muito além das fronteiras dos laboratórios, articula-se com o desenvolvimento e aplicação de tecnologias genômicas, mercado e novas (ou velhas) expressões identitárias. 


\section{Agradecimentos}

Agradecemos às pessoas e instituições que tornaram essa publicação possível. O seminário realizado em Belém contou com a participação de Ândrea Kely Campos Ribeiro dos Santos, Luiz Fernando Dias Duarte, Michael Montoya e Peter Fry como debatedores das sessões. Verlan Valle Gaspar Neto e Juliana Kabad proveram importante apoio durante a fase de organização do evento. O seminário, que foi possível a partir de financiamento do Conselho Nacional de Desenvolvimento Científico e Tecnológico (CNPq) e da British Academy, fez parte das atividades do recém-implantado Programa de Pós-graduação em Antropologia da Universidade Federal do Pará (PPGA - UFPA). ${ }^{7}$ Agradecemos os comentários que Gláucia Silva e Verlan Valle Gaspar Neto fizeram acerca de uma versão prévia desta Apresentação. Para a publicação desta coletânea foi fundamental o apoio da Fundação Carlos Chagas de Amparo à Pesquisa do Estado do Rio de Janeiro (Faperj), através de auxílio à editoração (processo no. E26-111.211/2011).

\section{Referências}

ABU EL-HAJ, N. The genetic reinscription of race. Annual Review of Anthropology, 36: 283-300, 2007.

ADAMS, M. B. Toward a comparative history of eugenics. In: ADAMS, M. (org.). The Wellborn Science: eugenics in Germany, France, Brazil and Russia. New York: Oxford University Press, 1990.

ASCHROFT, R. Race in medicine: from probability to categorical practice. In:

7 A presente coletânea faz parte do mesmo esforço reflexivo que também gerou, recentemente, o livro Racial identities, genetic ancestry, and health in South America, organizado por Sahra Gibbon, Ricardo Ventura Santos e Monica Sans (Gibbon, Santos \& Sans, 2011). Ambos derivaram de iniciativas que visaram primordialmente considerar questôes referentes à identidade racial e novas tecnologias genéticas tomando como foco de análise o contexto sul-americano. Decorrente dessa proximidade temática e conceitual, alguns dos pontos desenvolvidos ao longo desta apresentação também foram abordados na Introdução do volume organizado por Gibbon, Santos e Sans (2011). 
ELLISON, G. \& GOODMAN, A. H. (orgs.). The Nature of Difference: science, society and human biology. Boca Raton: CRC Press, Taylor \& Francis Group, 2006. ATKINSON, P.; GLASNER, P. \& LOCK, M. (orgs.). Handbook of genetics and society: mapping the new genomic era. London: Routledge, 2009.

BAUMAN, Z. Modernity and ambivalence. Cambridge: Polity Press, 1991. BLISS, C. Racial taxonomy in genomics. Social Science \& Medicine, 73:

BOLNICK, D. A. Individual ancestry inference and the reification of race as a biological phenomenon. In: KOENIG, B. A.; LEE, S. S. J. \& RICHARDSON, S. S. (orgs.). Revisiting race in a genomic age. Piscataway: Rutgers University Press, 2008.

BROWDIN, P. 'Bio-ethics in action' and human population genetic research. Culture, Medicine and Psychiatry, 29: 145-178, 2005.

DUSTER, T. Race and reification in science. Science, 307: 1.050-1.051, 2005. FISCHER, M. J. J. Emergent forms of life and the anthropological voice. Durham: Duke University Press, 2003.

FRANKLIN, S. The anthropology of science. In: MACLANCY, J. (Org.). Exotic no more: anthropology and the front lines. Chicago: University of Chicago Press, 2002.

FUJIMURA, J. H. \& RAJAGOPALAN, R. Different differences: the use of 'genetic ancestry' versus race in biomedical human genetic research. Social Studies of Science, 41: 5-30, 2011.

FUJIMURA, J. H.; DUSTER, T. \& RAJAGOPALAN, R. (orgs.). Introduction: race, genetics, and disease: questions of evidence, matters of consequence. Social Studies of Science, 38, p. 643-656, 2008.

FULLWILEY, D. The molecularization of race: institutionalizing human difference in pharmacogenetics practice. Science as Culture, 16: 1-30, 2007. GIBBON, S. \& NOVAS, C. (orgs.). Biosocialities, identity and the social sciences. London: Routledge, 2008.

GIBBON, S.; SANTOS, R. V. \& SANS, M. (orgs.). Racial identities, genetic ancestry, and health in South America: Argentina, Brazil, Colombia, and Uruguay. New York, London: Palgrave MacMillan, 2011.

HEATH, D.; RAPP, R. \& TAUSSIG, K. S. Genetic citizenship. In: NUGENT, 
D. \& VINCENT, J. (orgs.). A companion to the anthropology of politics. Malden: Blackwell, 2007.

HOCHMAN, G.; LIMA, N. T. \& MAIO, M. C. Paths of eugenics in Brazil: dilemmas of miscegenation. In: ALISON, B. \& PHILIPPA, L. (orgs.). The Oxford handbook of the history of eugenics. New York: Oxford University Press, 2010. INDA, J. X. (org.). Anthropologies of modernity: Foucault, government ability and life politics. London: Blackwell Publishing, 2005. KAHN, J. Misreading race and genomics after BiDil. Nature Genetics, 37:
$655-656,2005$.

KENT, M. \& SANTOS, R.V. "Os charruas vivem" nos Gaúchos: a vida social de uma pesquisa de "resgate" genético de uma etnia indígena extinta no Sul do Brasil. Horizontes Antropológicos, 18(1), 2012 (em publicação).

KITTLES, R. A. \& WEISS, K. M. Race, ancestry and genes: implications for defining disease risk. Annual Review of Genomics and Human Genetics, 4: 33-67, 2003.

KOENIG, B. A; LEE, S. S. J. \& RICHARDSON, S. S. (orgs.). Revisiting race in a genomic age. Piscataway: Rutgers University Press, 2008.

KRIMSKY, S. \& SLOAN, K. (orgs.). Race and the genetic revolution: science, myth, and culture. New York: Columbia University Press, 2011.

LOCK, M. Medical knowledge and body politics. In: MACLANCY, J. (org.). Exotic no more: anthropology and the front lines. Chicago: University of Chicago Press, 2002.

MAIO, M. C. \& SANTOS, R. V. (orgs.). Raça como questão: história, ciência e identidades no Brasil. Rio de Janeiro: Fiocruz, 2010.

MONTOYA, M. Making the Mexican diabetic: race, science, and the genetics of inequality. Berkeley: University of California Press, 2011.

NELSON, A. Bio science: genetic ancestry testing and the pursuit of African ancestry. Social Studies of Science, 38: 759-783, 2008.

ONG, A. \& COLLIER, S. J. (orgs.). Global assemblages: technology, politics, and ethics as anthropological problems. Malden, Oxford: Blackwell Publishing, 2005. PÁLSSON, G. Anthropology and the new genetics. New York: Cambridge University Press, 2007.

RABINOW, P. Artificiality and enlightenment: from sociobiology to biosocia- 
lity. In: CRARY, J. \& KWINTER, S. (orgs.). Incorporations. New York: Zone Books, 1992.

RACE, ETHNICITY, AND GENETICS WORKING GROUP (REGWG).

The use of racial, ethnic, and ancestral categories in human genetics research. American Journal of Human Genetics, 77: 519-532, 2005.

RAJAN, K. S. Biocapital: the constitution of post-genomic life. Durham: Duke University Press, 2006.

ROSE, N. The politics of life itself: biomedicine, power and subjectivity in the twenty-first century. Princeton: Princeton University Press, 2007.

SANTOS, R. V. \& MAIO, M. C. Antropologia, raça e os dilemas das identidades na era da genômica. História Ciência Saúde-Manguinhos, 12: 447-468, 2006. SANTOS, R. V. et al. Color, race and genomic ancestry in Brazil: dialogues between anthropology and genetics. Current Anthropology, 50: 787-819, 2009. STEPAN, N. L. The hour of eugenics: race, gender and nation in Latin America. Ithaca, London: Cornell University Press, 1991.

SUAREZ-KURTZ, G. Pharmacogenomics in admixed populations. Trends in Pharmacological Sciences, 26: 196-201, 2005.

TAUSSIG, K. S.; RAPP, R. \& HEATH, D. Flexible eugenics: technologies of the self in the age of genetics. In: GOODMAN, A.; HEATH, D. \& LINDEE, S. (orgs.). Genetic nature/culture: anthropology and science beyond the two-culture divide. Berkeley: University of California Press, 2003.

WADE, P. Race, nature, culture: an anthropological approach. London: Pluto Press, 2002.

WHITMARSH, I. \& JONES, D. S. (orgs.). What's the use of race: modern governance and the biology of difference. Cambridge: MIT Press, 2010. 


\section{PARTE I}

SAÚDE, GENÉTICA E SOCIEDADE: NOVAS/VELHAS QUESTÕES, NOVAS/VELHAS CONFIGURAÇÕES 


\section{DEGENERAÇÃO E EUGENIA NA HISTÓRIA DA PSIQUIATRIA MODERNA}

Sandra Caponi

Na segunda metade do século XIX articula-se um novo modo de entender as doenças mentais que já não estará relacionado exclusivamente a delírios, alucinações, atos violentos ou paixões irrefreáveis, fatos que até então concentravam a preocupação dos alienistas e psiquiatras. Esse deslocamento possibilitou que um conjunto cada vez mais amplo de condutas e comportamentos cotidianos passasse a fazer parte das classificações de patologias psíquicas que demandam intervenções terapêuticas. Emerge assim um novo campo de saber, onde fatos simples, como a tristeza profunda, a sexualidade da infância, o alcoolismo e os mais diversos desvios de comportamento passam a ser, pouco a pouco, objeto de discursos e intervenções médicas.

Assistimos, assim, à crescente consolidação desse espaço de saber e de intervenção que Michel Foucault (1999) denominou "medicina do não patológico". Nesse marco surge uma psiquiatria ampliada, interessada em definir e classificar as doenças do homem normal (Le Blanc, 2007), que parece ter tornado cada vez mais imprecisas e ambíguas as fronteiras entre o normal e o patológico. Atualmente existe uma imensa literatura dedicada a estudar os limites e as dificuldades dessa proliferação de diagnósticos ${ }^{1}$ que redefine quase todos os nossos sofrimentos e condutas em termos médicos (Camargo

\footnotetext{
1 As diversas edições do Diagnostic and Statistical of Mental Disorders (DSM) que se sucederam a partir de 1980 multiplicaram o número de diagnósticos psiquiátricos de acordo com sintomas clínicos bastante ambíguos, supostas etiologias e novas terapêuticas, que podem ser ou não farmacológicas (Conrad, 2007).
} 
Jr. \& Nogueira, 2009; Horwitz \& Wakefield, 2007; Conrad, 2007; Martinez Hernáez, 2008).

Pretendo analisar as condições históricas que possibilitaram o surgimento dessa nova configuração epistemológica pela qual a psiquiatria se tornou, ao mesmo tempo, intra e extra-asilar, capaz de se referir tanto aos delírios e alucinações, como aos sofrimentos que fazem parte da condição humana.

Claude Olivier Doron (2008) formula algumas perguntas sobre os transtornos de personalidade que permitem resumir as principais questões que nortearam esta exposição:

Como se construiu essa idéia pela qual existe certo tipo de loucura - ou melhor, de "transtorno" - que já não se caracteriza por idéias delirantes, dificuldades de imaginação, mas por atos e comportamentos considerados socialmente aberrantes? Como surge essa figura da personalidade anormal que reagrupa todos os pequenos desvios de conduta de um indivíduo desde sua infância? Quem vai se ocupar da reparação, da recuperação, para evitar um perigo social? Questões foucaultianas, sem dúvida. (Doron, 2008:11)

Essas perguntas nos levam a indagar, por exemplo, como surge, como se valida e como se difunde esse saber médico relacionado ao não patológico. Isto é, a compreender a partir de que marco epistemológico, de que saberes e de que estratégias discursivas se consolidou essa psiquiatria ampliada que surge na segunda metade do século XIX e que hoje parece ter renascido com força inesperada. Para responder a essas questões deveremos analisar as estratégias que foram construídas ao longo da história da psiquiatria para administrar essas patologias e reparar esses desvios.

Tomando como ponto de partida a análise que Foucault realiza em seu curso no Collège de France entre 1974 e 1975, é possível afirmar que o surgimento dessa nova psiquiatria ampliada decorre da aparição de uma nova figura que concentrará as atenções dos psiquiatras da segunda metade do século XIX: a figura dos dege- 
nerados. Para Foucault (1999: 298) “a degeneração é a peça teórica maior que permite a medicalização do anormal. O degenerado é o anormal miticamente - ou se vocês preferem, cientificamente medicalizado".

Situamos, assim, a origem da psiquiatria ampliada no Tratado de degeneração física, moral e mental, publicado por Benedict August Morel em 1857. Ali, Morel define o que será considerado o princípio geral da teoria da degeneração: "Os seres degenerados formam grupos e famílias com elementos distintivos relacionados invariavelmente às causas que os transformaram em isso que eles são: um desvio mórbido do tipo normal da humanidade" (Morel, 1857: 75). Tomando como ponto de partida essa afirmação, pretendo analisar as transformações sofridas pelo conceito de degeneração e sua vinculação com as estratégias eugênicas iniciadas nas últimas décadas do século XIX.

\section{Psiquiatria e degeneração}

No momento em que a teoria da degeneração se consolida como programa de pesquisa, a psiquiatria poderá começar a estabelecer vínculos diretos entre um desvio de conduta e um estado anormal (herdado, mas definitivo) que reclama uma intervenção psiquiátrica. Desse modo, essa longa série de pequenas condutas anormais, aberrantes, desviantes, que se sucedem nos Anais médico-psicológicos, passará a se transformar no eixo articulador da nova psiquiatria. Esse fato pode ser observado pela permanência de textos que vinculam o problema da degeneração com condutas cotidianas publicados nos Anais médico-psicológicos e nos Anais de higiene e medicina legal entre os anos 1860 e 1926.

Para compreender a teoria da degeneração, é preciso falar de um tipo particular de hereditariedade, uma herança não definida, em que toda e qualquer anomalia pode surgir e se espalhar a partir de um sujeito identificado como anormal. "O estudo da hereditariedade, 
ou a localização da herança na origem das anormalidades, constitui essa 'meta-somatização' que foi necessária para construir o edifício da degeneração" (Foucault, 1999: 296).

Para Morel e seus seguidores, os anormais levam inscrita em seus corpos sua própria inviabilidade. "A hereditariedade é veículo de transmissão progressiva de toda forma de degeneração adquirida ao longo de quatro gerações, até a esterilidade dessa última" (Serpa, 2006: 129). A partir das árvores genealógicas construídas para determinar a hereditariedade dos degenerados, a psiquiatria delimitará um novo campo de ação e construirá novas estratégias de poder. "Com efeito, a partir do momento em que a psiquiatria adquire a possibilidade de relacionar qualquer desvio, irregularidade, retardo, a um estado de degeneração, daí em diante ela conquistará uma possibilidade de ingerência indefinida sobre os comportamentos humanos" (Foucault, 1999: 298).

Na segunda metade do século XIX e nas primeiras décadas do século XX a degeneração se transformou em um novo paradigma de análise social. Todos os fenômenos aos quais a sociedade devia confrontar-se eram interrogados a partir dessa perspectiva sombria. A natalidade baixa? É a confirmação da degradação biológica da raça francesa. O número de alcoólatras aumenta? Representa uma França que degenerará no futuro. Os escritores já não sabem escrever? Seu estado mental os faz ineficientes para a produção artística. Os exemplos podiam multiplicar-se ao infinito. (Coffin, 2003: 191)

O conceito de degeneração ingressará no âmbito da psiquiatria como saber legítimo e consolidado com Valentin Magnan (1893), nos anos 1880, tendo continuidade com os estudos de seus seguidores (ver Quadro a seguir). Todos eles conservavam a ideia, já esboçada por Cabanis (1802) no fim do século XVIII, da necessidade de realizar estudos de anatomopatologia cerebral para explicar as patologias mentais. Magnan (1893) ampliará a classificação de patologias 

logias mentais ou síndromes.

Quadro sinótico das degenerações mentais - Os heredodege-
ados (Magnan, 1893: 150)

1- Idiotismo, imbecilidade e debilidade mental.

2- (Desequilibrados) Anomalias cerebrais: defeito no equilíbrio das faculdades morais e intelectuais.

3- Síndromes episódicas hereditárias

(a) Loucura de dúvida

(b) Medo de tocar

(c) Onomatomania: 1) busca angustiosa de uma palavra, 2) impulso irresistível de repetir uma palavra, 3) medo de usar palavras comprometedoras etc.

(d) Aritmetomania

(e) Amor exagerado pelos animais: loucuras dos antivivissecionistas

(f) Cleptomania, dipsomania, oniomania (mania de com-

(g) Mania de jogar

(h) Piromania e pirofobia

(i) Impulsos homicidas e suicidas

(j) Aberrações sexuais, perversões, anomalias: reflexo cortical posterior, refiexo cortical anterior, erotomanias,

(k) Agorafobia, claustrofobia, topofobia

(l) Abulia

4- (a) Mania de raciocínio, loucura moral (persecutórios)

(b) Delírios múltiplos: delírio ambicioso, religioso, de per- 
(c) Delírio sistemático único.

(d) Ideias obsessivas

(e) Excitação maníaca, depressão melancólica

Esse quadro de Magnan sintetiza um imenso conjunto de síndromes que foram descritas e definidas nos Anais médico-psicológicos, publicação da Associação Médico-Psicológica, da qual foi presidente. Os Anais evidenciam a existência de uma longa dinastia dessas "síndromes". Como afirma Foucault: inicialmente aparece a agorafobia; logo a seguir, as claustrofobias; as doenças incendiárias surgem em 1867; a cleptomania é descrita pela primeira vez em 1879; os exibicionismos, em 1877; o masoquismo, em 1875; a homossexualidade é enunciada como síndrome pela primeira vez em 1870, nos arquivos de neurologia. Esse somatório de desvios pode ser indefinidamente ampliado, podem ser sempre adicionadas novas condutas que reclamam intervenção psiquiátrica. Assim, perante um fato social como o surgimento de ligas de proteção de animais ou de ligas antivivisseção, Magnan descobrirá essas síndromes bizarras, que denomina "síndrome de antivivisseção" (Foucault, 1999: 293) e "vegetarianismo".

A teoria da degeneração não permaneceu nos limites de França, estendeu-se por diversos locais da Europa (particularmente Itália e Alemanha) e pela América Latina (Brasil, Argentina, México e Colômbia). De modo que, cinquenta anos após a publicação do tratado de Morel, um psiquiatra alemão, considerado até hoje como o pai da psiquiatria moderna, Emil Kraepelin (1907), retoma e tematiza o conceito de degeneração em diversos estudos (Kraepelin, 1917; 2007; 2009). Apesar de existirem inúmeras diferenças que o separam dos estudos dos degeneracionistas clássicos, Kraepelin dedica-se a analisar a relevância e pertinência que esse conceito tem para os estudos psiquiátricos. Publica, em 1908, um texto denominado Sobre a degeneração, onde reaparecem muitas das premissas defi- 
nidas por Morel e Magnan para classificar as patologias mentais. O quadro de doenças psiquiátricas elaborado por Kraepelin mantém certas semelhanças sugestivas com a classificação defendida pelos discípulos de Magnan. No Manual de psiquiatria para médicos e estudantes (Kraepelin, 1907), onde se enuncia a clássica distinção entre demência precoce e psicose maníaco-depressiva, permanecem muitas síndromes de degeneração com denominações idênticas, como a onomatomania, descrita e enunciada por Magnan.

Algumas dessas ideias serão retomadas mais tarde, nos anos 1970 e 1980, por um grupo de médicos da Universidade de Washington, Eli Robins (1921-1994), Samuel Guze (1924-2000) e George Winokur (1925-1996), que se definem e reconhecem como neokraepelinianos (Decker, 2007). Claro que, nesse momento, o conceito de degeneração será substituído ou transvertido por denominações modernas, tais como a constituição psíquica ou a predisposição patológica, termos cuja conotação política e epistemológica não pareceria carregar o peso das críticas dirigidas a essa velha teoria.

No entanto, o velho discurso da degeneração, livre de todos os elementos metafísicos presentes em Morel, assim como dos quadros bizarros definidos por Magnan, reaparece com Kraepelin como um marco de referência que legitima muitas das certezas da psiquiatria moderna. Entre essas certezas podemos destacar as afirmações referentes ao caráter hereditário das patologias mentais, a impossibilidade de cura ou reversibilidade da loucura, a origem biológica e a localização cerebral dos transtornos psiquiátricos, a introdução do discurso sobre a prevenção e o risco no âmbito da saúde mental, assim como a insistência em definir comportamentos desviados ou anomalias em termos médicos.

\section{Degeneração e eugenia}

Nem Kraepelin nem Morel se limitaram a utilizar a teoria da degeneração exclusivamente com a finalidade de classificar doenças 
psiquiátricas ou de estabelecer uma nosologia e uma terapêutica cada vez mais precisas. Ambos pretendiam criar intervenções concretas no espaço social capazes de antecipar e prevenir desvios de comportamentos e patologias mentais. Essas estratégias de intervenção social, que são denominadas por Morel de "tratamento moral" (Morel, 1857) e por Kraepelin, de "psiquiatria preventiva" (Kraepelin, 1907), representam dois modos diferentes de compreender as intervenções sociais preventivas no campo da saúde mental.

Para poder compreender essa diferença devemos analisar os vínculos existentes entre a teoria da degeneração e o discurso dos eugenistas. Pois, nos cinquenta anos que separam o Tratado de Morel do texto que, em 1908, Kraepelin dedica à questão da degeneração, o discurso eugênico foi ganhando terreno como um modo de controlar a ameaça representada pelas doenças mentais e pela criminalidade. Devemos lembrar que já em 1907 foi promulgada, no estado americano de Indiana, a legislação que permitia a esterilização dos criminosos e de doentes mentais. Em 1909 a mesma legislação será aprovada para os estados de Washington, Connecticut e Califórnia, até que, no ano 1950, serão 33 os estados da América do Norte que possuem essa legislação. O mesmo acontecerá entre os anos 1920 e 1935 na Suécia, Dinamarca, Finlândia, Noruega e Alemanha (Pichot, 1995). ${ }^{2}$

Em sentido estrito, existem diferenças significativas entre os teóricos da degeneração e os eugenistas que podem ser observadas na diversidade de intervenções defendidas por uns e outros. Em 1857 Morel defendia como estratégias de regeneração e prevenção das patologias mentais intervenções sociais higiênicas sobre o meio ambiente, tais como o controle das intoxicações provocadas pelas condições insalubres de existência, a melhoria das condições de trabalho ou o controle da miséria urbana. Kraepelin, ao contrário,

2 Com características diferentes, o discurso eugênico também ganhou terreno na América Latina, como pode ser observado no caso concreto do Brasilo a partir dos estudos de Stepan (2005) e Souza et al. (2009), entre outros. ] 
não compartilhava do otimismo de Morel. Para ele, as estratégias de proteção social aos indivíduos mais vulneráveis representavam um obstáculo para a purificação eugênica da raça:

Em todo caso, é impossível saber quantos imbecis, epiléticos, psicopatas, criminosos, prostitutas e vagabundos são filhos de pais alcoólicos ou sifilíticos e herdaram a inferioridade de seus pais. É óbvio que o dano será em parte compensado por sua menor capacidade para sobreviver. Mas, infelizmente, a extensão de nossos programas de assistência social tem o efeito de impedir a autopurificação natural de nosso povo. Temos pouca razão para esperar que, em longo prazo, nossa capacidade de regeneração possa ser suficientemente forte para neutralizar os perigos cada vez maiores que ameaçam a nossas células germinais. (Kraepelin, 1907: 400)

Kraepelin se aproximava assim das ideias eugênicas defendidas pelos seguidores de Galton (1988), fundamentalmente nos Estados Unidos, Inglaterra e Alemanha, distanciando-se das teses defendidas pelos teóricos da degeneração da segunda metade do século XIX, que, como Morel ou Magnan, confiavam na regeneração e na "moralização das massas" (Morel, 1857: 687).

Mas, por que razão falar de eugenia na França de 1857 se "somente em 1883 Galton (1988) funda o neologismo que definirá em 1904 como: o estudo dos fatores socialmente controláveis que podem elevar ou diminuir as qualidades raciais das gerações futuras tanto físicas quanto mentais" (Carol, 1995: 9)?

Tudo parecia indicar que a medicina francesa pré-galtoniana permanecia alheia aos postulados eugênicos, e essas ideias somente seriam aceitas depois que um pequeno grupo de representantes franceses participou do I Congresso Internacional de Eugenia realizado em Londres em 1912. Foram a esse encontro aproximadamente vinte representantes franceses, demógrafos, estatísticos, homens políticos e antropólogos, sendo o grupo mais numeroso o dos médicos, especialistas em puericultura, em venereologia e medicina mental. 
Faziam parte deste último subgrupo os psiquiatras Fillassier, Marie e Magnan. Ainda que esse dado pareça indicar uma aproximação entre a teoria da degeneração e a eugenia, eles se limitaram a apresentar no congresso estudos centrados na problemática da degeneração. No caso de Magnan, um trabalho relativo à luta contra o alcoolismo. Um ano mais tarde, em 1913, será criada a Sociedade Francesa de Eugenia, porém nessa sociedade Magnan não terá nenhuma participação. Ainda que com algumas exceções, como Charles Richet (1850-1935 - Nobel de medicina em 1913), o discurso eugênico não parecia ter cativado as mentes dos médicos e psiquiatras franceses. Já no II Congresso Internacional de Eugenia, realizado em Nova Iorque no ano 1921, a delegação francesa ficou reduzida a três membros, sendo: um estatístico (e membro da Sociedade Francesa de Eugenia), um biólogo, um sociólogo, e nenhum médico. ${ }^{3}$

Ocorre que as preocupações dos teóricos da degeneração e dos eugenistas não eram idênticas, ainda que em muitos pontos pudessem se aproximar. No entanto, a teoria da degeneração parecia ter criado a condição de possibilidade para a emergência do eugenismo. Se as raças se degradam, se elas degeneram e se esse processo ocorre pela transmissão hereditária de estigmas de degeneração que se agravam a cada geração, então seria possível dar um passo a mais para deter a progressiva patologização dos povos, utilizando estratégias eugênicas. Esse passo a mais não foi dado pelos teóricos da degeneração: nenhuma defesa de esterilização de certos grupos, nem de políticas genocidas, como as defendidas pelos eugenistas alemães. Ao contrário, a única estratégia eugênica defendida pelos degeneracionistas foi o controle dos matrimônios disgênicos, inicialmente destinado ao controle de filhos de sujeitos com sífilis terciária. Essa iniciativa, que surge nas últimas décadas

\footnotetext{
3 Para compreender a abrangência internacional do movimento eugenista, lembremos que o Primeiro Congresso Brasileiro de Eugenia foi realizado em 30 de junho de 1929, tendo como eixo de preocupação o problema da imigração (Souza et al. 2009: 772).
} 
do século XIX, resulta na "tardia e anódina legislação de exame pré-nupcial instaurada somente no ano 1942” (Carol, 1995: 11), numa França ocupada pelo nazismo.

Ainda que a preocupação pela qualidade da raça francesa perpassasse o discurso dos degeneracionistas, seria possível adivinhar ali, como afirma Foucault, algo assim como um racismo sem raça. Os teóricos da degeneração, à semelhança de Morel e Magnan, estavam preocupados com a medicina mental - a conservação ou degradação da raça estaria diretamente associada ao par normal patológico, e não, como era o caso de Gobineau ou Richet (1922), à diferenciação de povos superiores ou inferiores.

Morel considerava que "entre o estado intelectual de um bosquímano selvagem e do europeu mais avançado de sua civilização, existe menos diferença da que existe entre o estado intelectual desse mesmo europeu e o de um ser degenerado" (Morel, 1857: 46). Para ele, a população que de modo mais claro parecia estar condenada à degradação e à extinção não fazia parte dos chamados povos primitivos de pele mais escura. Era entre os suecos que podia se prever a maior degradação, pois era ali que se registrava o maior nível de consumo de álcool. No entanto, a associação entre degeneração e raça (no sentido que hoje damos a essa noção) aparece de modo mais evidente em outros degeneracionistas, como é o caso de Kraepelin, cujas afirmações racistas e eugênicas têm como alvo privilegiado o que ele denominava a "degeneração do povo judeu".

Existe outra diferença entre os teóricos da degeneração e os eugenistas: o modo como ambos pensam os vínculos entre indivíduo, meio e hereditariedade. Como vimos, as intervenções no meio, pela mediação da higiene física e moral, foram consideradas por Morel como o instrumento chave de regeneração. Apesar de acreditar na gravidade crescente das degenerações que se sucedem nas diversas gerações até a esterilidade da última, ele compartilhava também do otimismo dos higienistas. Acreditava que as intervenções no 
ambiente permitiriam reduzir os elementos tóxicos e as condutas imorais. De acordo com os princípios neolamarkianos da herança dos caracteres adquiridos, essas alterações provocariam mudanças na célula germinal, que, independentemente de serem degenerativas ou regeneradoras, seriam transmitidas aos descendentes. Essas ideias tendem a desaparecer na lógica da ideologia eugênica. Para Galton (1988) e seus seguidores, o controle da herança independe das intervenções no meio, e, como vimos no caso de Kraepelin, eram comuns as afirmações herdeiras do darwinismo social que falam do caráter nocivo dessas intervenções e programas de assistência social argumentando que eles impediriam a eliminação dos menos aptos na luta pela vida.

Os teóricos da degeneração posteriores a Morel, que, como Magnan, não aceitaram as hipóteses de inviabilidade e autopurificação dos anormais, apresentaram propostas de intervenção social semelhantes àquelas defendidas por Morel: controle do alcoolismo, asilos para doentes psiquiátricos, higiene física e moral, reivindicação do exame pré-nupcial para sifilíticos e alcoólatras. A isso se limitavam as estratégias biopolíticas defendidas pela maior parte dos degeneracionistas franceses.

Desde a criação da Sociedade Francesa de Eugenia em 1913, cada vez ganhará mais força a puericultura, fazendo que, a partir dos anos 1920, o discurso médico se distancie das ideias eugênicas, reivindicando para si a originalidade dos estudos dedicados à procriação de indivíduos fortes e saudáveis. ${ }^{4}$ A puericultura considerava fundamental conhecer as anomalias hereditárias tanto como definir estratégias de higiene física e moral, consideradas regeneradoras da espécie.

4 Assim, em 1927, Pinard afirmou: "Tomamos o termo eugenia por respeito ao nome de seu precursor, que era um parente de Darwin: Sir Francis Galton. Mas, foi na França que se deu a seguinte definição para a puericultura: 'Ciência que tem como objetivo a pesquisa, o estudo e a aplicação de todos os conhecimentos relativos à conservação e melhoramento da espécie humana"' (apud Carol, 1995: 143). 
Tudo pareceria indicar que degeneração e eugenia se movem por caminhos diferentes. Porém, como já foi dito, será no marco teórico iniciado pelos degeneracionistas, que aborda a degradação progressiva de indivíduos e raças, que encontram sua legitimidade as estratégias para limitar (pelo controle de matrimônios, castração, esterilização ou genocídio) a proliferação de sujeitos condenados à herança mórbida. Assim, pode-se dizer que ambos os discursos compartilham um mesmo ponto de partida: o "mito da normalidade hereditária".

O fato que preocupava tanto degeneracionistas quanto eugenistas era identificar uma série de características físicas e comportamentais consideradas indesejáveis, que deviam ser pensadas como desvio da normalidade. Assim, os discursos elaborados pelos degeneracionistas e pelos eugenistas se inscrevem num mesmo eixo: o delimitado pelo par normal/patológico.

A caça dos estigmas (Carol, 1995) será inaugurada, em 1857, com o Tratado de Morel e se multiplicará ao longo da segunda metade do século XIX. Desde então, nunca deixarão de aparecer novos estigmas que permitirão ampliar, cada vez mais, a margem de intervenção dos degeneracionistas. Em 1907, Kraepelin prolongará essas preocupações ao afirmar, lembrando Morel, que para reconhecer patologias mentais hereditárias era necessário identificar "estigmatas físicos, como malformações do paladar ou dos órgãos sexuais, estrabismo congênito, albinismo, posição errada dos dentes, dos olhos, etc." (Kraepelin, 1907: 99). As medidas do crânio indicavam o desenvolvimento do córtex cerebral, a posição dos olhos podia revelar doenças e "um cuidadoso exame das orelhas podia revelar uma causa suficiente para alucinações" (Kraepelin, 1907: 99).

No ano 1893, Magnan já tinha ampliado os estigmas físicos e morais descritos por Morel, adicionando comportamentos como roubar, ter medo de sair da casa, limpar obsessivamente as mãos, consumir abusivamente álcool ou outros tóxicos (como cocaína ou absinto). Os estigmas físicos e morais podiam estender-se ao infi- 
nito, incluindo tiques, manias, comportamentos bizarros, além de características físicas, como a baixa ou alta estatura, o excesso de gordura ou a fealdade. O agrupamento de estigmas constituía, para Magnan, patologias ou síndromes de degeneração. Assim, para os degeneracionistas, todo comportamento ou conformação física poderia passar a ser considerado, em algum momento, como uma anomalia. Criava-se assim uma confusa associação de estigmas e patologias, que passaram a ser considerados como signos de degeneração: "microcefalia, nanismo, alcoolismo, idiotismo, cretinismo, gota, paludismo, epilepsia, tuberculose, raquitismo" (Carol, 1995: 10).

Essa confusa associação de características físicas, patologias e comportamentos somente pode ser compreendida tendo como referência o mito de origem, que é a normalidade e o desvio hereditário. Ele se inicia com a teoria da degeneração, mas se mantém inalterado no discurso dos eugenistas, legitimando a construção de estratégias destinadas a garantir a reprodução da normalidade e a eliminar desvios hereditários. Um dos mais reputados eugenistas franceses, membro da Sociedade Eugênica de França e Prêmio Nobel de Medicina, Charles Richet, em um escrito publicado em 1922, denominado A seleção humana, indica quais eram os sujeitos portadores de estigmas que deveriam ser considerados genitores ruins, susceptíveis de interdição e repressão. A lista apresenta mais de 60 indicações, dentre elas: ser muito grande ou muito pequeno; doente mental; contrafeitos; doentes em geral; alcoólicos; sifilíticos; epilépticos; tuberculosos; degenerados; idiotas; muito gordos; malignos; rebeldes a toda disciplina; muito feios; criminosos; proxenetas etc.

Da mesma maneira que ocorre com a inumerável lista de estigmas físicos e psíquicos definidos pelos degeneracionistas, a única lógica que permitia unificar essa diversidade era a identificação entre normalidade e saúde e, correlativamente, entre desvios e patologia. Os eugenistas, do mesmo modo que Morel, identificavam a normalidade com o tipo médio da humanidade, já não com a explicação religiosa 
do ser que constituía o ponto mais alto da criação divina, mas com o tipo médio constituído matematicamente a partir da frequência (Carol, 1995).

No texto, repleto de afirmações racistas e defendendo a castração de doentes e anormais, Richet afirma: “As virtudes que devem considerar-se indispensáveis podem ser resumidas em uma palavra: a de normalidade. É preciso que os progenitores não se desviem da média geral do tipo humano" (Richet, 1922: 150). É essa ideia de normalidade que permite compreender a diversidade de estigmas apresentados em sua lista. Em contrapartida, as condições exigidas para o progenitor ideal não se vinculavam com a ideia de perfeição, mas com a ideia de normalidade como padrão. Na caracterização da normalidade transparece o ideal do justo médio: "nem muito grande nem muito pequeno, o homem não deve ter os cabelos muito lisos nem cacheados, o ventre deve ser reto, mas ligeiramente arredondado, deve ter músculos, mas sem exageração" (Richet, 1922: 151).

Se a ideia de normalidade como tipo médio da humanidade aproxima o discurso dos eugenistas e dos teóricos da degeneração, algo semelhante ocorrerá com o modo como se determina o caráter hereditário dos estigmas morais. O uso de árvores genealógicas aparece como uma estratégia analítica em Magnan, e mais tarde aparecerá nos eugenistas com o objetivo de justificar as intervenções eugênicas sobre famílias e populações.

Assim, em Hereditariedade e alcoolismo, publicado por Legrain (1889), que foi um discípulo direto de Magnan (1893), é apresentado um quadro demonstrativo da sucessão de patologias de gravidade crescente que caracteriza as famílias de alcoólicos. Define um esquema que se repete, sendo a primeira geração de alcoólico simples, a segunda de alcoólicos com acidente cerebral e a terceira de sujeitos com acidentes convulsivos na primeira infância, sucedidos pela aparição de fenômenos complexos. As tabelas expostas mostram a evolução de diversas famílias de alcoólicos por três ou mais ge- 
rações, apresentando invariavelmente degenerações cada vez mais graves. Magnan conclui que se deve intervir, em casos extremos de alcoolismo, com o internamento asilar.

Quadros semelhantes de genealogias familiares se multiplicarão entre os eugenistas, porém com um objetivo biopolítico diferente, qual seja, a esterilização. É possível encontrar, ainda nos anos 1920 e 30, genealogias semelhantes apresentadas em publicações científicas e jornais de circulação massiva como modo de divulgar a importância da eugenia. No Sunday Oregonian podemos ler, por exemplo, o caso de Ada Jukes, nascida em 1740, que estaria na origem de uma árvore genealógica trágica: entre seus descendentes aparecem 64 débeis mentais, 174 perversos sexuais, 196 ilegítimos, 77 criminosos e assassinos e, representando um estigma moral, 147 pobres. O quadro se inicia com a seguinte afirmação: "sua esterilização teria custado 150 dólares", e conclui com a seguinte pergunta: "deixaremos que as Adas Jukes de hoje continuem multiplicando a pobreza e a criminalidade?" (Gouyon \& Henry, 1997: 93). As árvores genealógicas possuem uma dupla utilidade: representam um marco explicativo para os teóricos da degeneração e possibilitam a validação e legitimação de estratégias de controle e intervenção para os defensores do eugenismo.

\section{À guisa de conclusão}

Do dito até aqui, pode-se afirmar que degeneração e eugenia seguiram caminhos e lógicas diferentes e produziram estratégias biopolíticas distintas. No entanto, tudo parece indicar que a condição de possibilidade da eugenia deve ser procurada nos temores instalados pela teoria da degeneração. Tanto os degeneracionistas quanto os eugenistas construíram seus argumentos adotando como estratégia explicativa para todos os males sociais o que podemos denominar de "o mito da degeneração hereditária". Ambos identificaram saúde com normalidade, e esta com o tipo médio da humanidade, asso- 
ciando todo e qualquer desvio a processos hereditários patológicos, degenerativos ou disgênicos.

Em ambos os casos e perante a impossibilidade de construir explicações hereditárias bem fundadas, limitaram-se a descrever estigmas físicos e morais, a construir árvores genealógicas e a multiplicar os temores vinculados com novas patologias e novas ameaças que deveriam ser antecipadas e evitadas, seja pelas estratégias eugênicas ou pelos controles e intervenções dos alienistas no campo social.

Sabemos que hoje, como nos tempos de Morel, Magnan ou Kraepelin, são poucas as certezas que os estudos de anatomopatologia, de genética ou neurofisiologia cerebral podem aportar para a compreensão dos processos biológicos das patologias mentais ou dos comportamentos. Diferentemente da medicina clínica, que conta com "marcadores biológicos" (Pignarre, 2001), isto é, com parâmetros mais ou menos objetivos que permitem identificar certas patologias a partir da articulação entre determinados sintomas clínicos e determinadas lesões orgânicas, os parâmetros biológicos das condutas e das doenças mentais permanecem como um grande mistério. O que ocorre no campo da localização cerebral reaparece no campo das explicações hereditárias ainda que as "mitologias da herança" (Coffin, 2003: 255), que fizeram parte da história da degeneração e da eugenia ao longo do século XIX, tenham sido reforçadas e aprofundadas na era da genética.

Porém, algo desse passado remoto e esquecido parece que, ainda hoje, se obstina em aparecer. Sem pretender negar as profundas transformações introduzidas na percepção e na gestão dos fatos psíquicos e sociais nos anos posteriores à Segunda Guerra Mundial, ainda vemos reaparecer, tanto no âmbito das pesquisas científicas, quanto no espaço da mídia destinada ao grande público, esses velhos mitos da herança mórbida como marco explicativo privilegiado para uma imensa variedade de situações que nossa sociedade considera indesejáveis. Muitas das teses defendidas pelos teóricos da degeneração e logo retomadas pelos eugenistas parecem ter se prolongado até hoje, ainda que apa- 
reçam com novas roupagens. O que permanece inalterado é o sonho determinista de achar explicações neurogenéticas precisas para cada um de nossos comportamentos, aflições e sofrimentos.

Por esse motivo o biólogo e geneticista Steven Rose (2001) inicia seu livro de filosofia da biologia, denominado Trajetórias de vida: biologia, liberdade e determinismo, com a seguinte afirmação:

$\mathrm{O}$ atual entusiasmo pelas explicações biológicas deterministas da condição humana remonta-se a fins da década de 1960. Ele não foi impulsionado por alguma descoberta particular das ciências biológicas, nem por uma teoria nova e influente. Sua ascensão decorre de uma tradição anterior que é a do pensamento eugênico que, depois de conhecer um grande avanço em Estados Unidos na década de 1930, ficou eclipsada como conseqüência do Holocausto inspirado por idéias racistas. (Rose, 2001: 10)

Como resposta aos horrores da Segunda Guerra, criou-se, por algumas décadas, um consenso segundo o qual as raízes da desigualdade humana, seja de raça, de gênero, de etnia, não deviam ser procuradas em nossos genes, mas sim na distribuição desigual de riqueza e de poder entre grupos humanos.

Esse consenso parece ter-se quebrado nos últimos trinta anos, destinando-se cada vez maiores recursos e esforços à procura de explicações biológicas para os comportamentos, as desigualdades sociais, as mais variadas debilidades do caráter, as pequenas escolhas cotidianas, as exclusões e os conflitos urbanos. Esses fatos, entre muitos outros, parecem ter ingressado novamente no território das explicações médicas e psiquiátricas, repetindo esse estranho processo, iniciado por Morel e Magnan, de classificar fatos sociais como patologias psiquiátricas que reclamam uma intervenção terapêutica. Para cada um desses fatos, os defensores do reducionismo prometem a descoberta de alguma explicação neurogenética que possibilitaria a definição de intervenções eficazes e definitivas, uma terapêtica farmacológica ou uma estratégia preventiva que permitam substi- 
tuir a complexidade das explicações sociológicas ou psicológicas existentes.

O certo é que novas vozes aparecem a cada dia, seja nas mais prestigiosas publicações científicas ou no meio de comunicação mais popular, em defesa de alguma nova descoberta que possa permitir, finalmente, comprovar a veracidade do determinismo neurogenético de nossas escolhas e condutas. Assim,

[...] afirma-se que foram descobertos, não somente os genes de uma doença como o câncer de seio, mas também da homossexualidade, do alcoolismo (que tanto preocupara aos degeneracionistas), da criminalidade, chegando até a célebre especulação de Daniel Koshland, nesse momento diretor da revista Science, de que poderiam existir genes dos sem teto. (Rose, 2001: 313)

Em cada um desses casos, os defensores das explicações neurogenéticas serão cautelosos em afirmar que os fatos sociais também têm sua importância. Porém, perante o que consideram uma sucessão de medidas sociais pouco eficazes e pouco frutíferas, eles parecem reclamar para si o poder de descobrir as intervenções precisas, efetivas e definitivas para cada um dos problemas que tanto angustiam as nossas sociedades contemporâneas: a violência urbana, os sofrimentos psíquicos, as dificuldades de aprendizagem escolar, os sem-teto etc. Para essa ambição explicativa dos neurogeneticistas de hoje pode ser repetida a mesma advertência que Charpentier enunciou em 1893 para Magnan:

Tenhamos cuidado com essa tendência (da psiquiatria), ou então as pequenas loucuras da infância, as da adolescência, os tiques, todas as perturbações mais ou menos conhecidas da vontade, os estados emocionais, os defeitos de equilíbrio, as perturbações menores, poderão atingir o estatuto de doença mental. (Charpentier apud Magnan, 1893: 130)

O "triunfalismo arrogante" (Rose, 2001) das explicações neurogenéticas para comportamentos e sofrimentos parece ser tão sedutor 
para nossas sociedades contemporâneas, caracterizadas pela precariedade dos laços sociais, pela fragilidade laboral, pelos processos migratórios e pela violência urbana, como já foram as propostas dos degeneracionistas na conservadora sociedade europeia da segunda metade do século XIX, ou as intervenções racistas dos eugenistas nos Estados Unidos da década de 1930. Em cada um desses momentos históricos, as explicações biológicas parecem concentrar poderes reveladores capazes de ocupar o lugar abandonado perante a renúncia coletiva a procurar soluções sociais para problemas sociais.

\section{Referências}

CABANIS, P. Rapports du physique et du moral de l'homme. Paris: Bailliére, 1802. CAMARGO JR., K. \& NOGUEIRA, M. I. (orgs.). Por uma filosofia empírica da atenção à saúde: olhares sobre o campo biomédico. Rio de Janeiro: Fiocruz, 2009.

CAROL, A. Histoire de l'eugenisme en France. Paris: Seuil, 1995.

CONRAD, P. The medicalization of society. Baltimore: The Johns Hopkins University Press, 2007.

COFFIN, J. La transmission de la folie - 1850-1914. Paris: Harmattan, 2003. DECKER, H. How Kraepelinian was Kraepelin? How Kraepelinian are the neo-kraepelinians? From Emil Kraepelin to DSM-III. History of Psychiatry, 18: 337-361, 2007.

DORON, C.O. La maladie mental em question. In: MISSA, J., Les Maladies Mentales. Paris: PUF, 2008.

DORON, C. O. Archéologie des troubles de la personnalité. Seminaires $d u$ Centre Georges Canguilhem, 2009. Disponível em: <http://centrecanguilhem. net>. Acesso em: 15 maio 2009.

FOUCAULT, M. Les anormaux. Paris: Seuil, 1999.

GALTON, F. Herencia y eugenesia. Madrid : Alianza, 1988.

GOUYON, P. \& HENRY, J. Les Avatars du gene. Paris: Belin, 1997.

LE BLANC, G. Les maladies de l'homme normal. Paris: VRIN, 2007.

HORWITZ, A. \& WAKEFIELD, J. The loss of sadness. Oxford: Oxford University Press, 2007. 
KRAEPELIN, E. Clinical psychiatry: a textbook for students and physicians. New York: Macmillan Company, 1907. 1917. One hundred years of psychiatry. New York: Philosophical Library, On the question of degeneration. History of Psychiatry, 18: 398-404, 2007.

As formas de manifestação da insanidade. Revista Latino-Americana de Psicopatologia Fundamental, 12: 167-194, 2009.

LE BLANC, G. Les maladies de l'homme normal. Paris: VRIN, 2007.

LEGRAIN, P. Hérédité et alcoolisme. Paris : Octave Doin, 1889.

MAGNAN, V. Recherches sur les centres nerveux : alcoolisme, folie des héréditaires dégénérés. Paris: Masson, 1893.

MARTINEZ HERNÁEZ, A. Antropología médica: teorías sobre la cultura, el poder y la enfermedad. Barcelona: Anthropos, 2008.

MOREL, B. A. Rapport fait à la societe medico-psicologique sur le Traité de Dégénérescence. Annales Médico-Psicologiques, 3: 4, 1857.

PICHOT, A. L'eugenisme. Paris: Hatler, 1995.

PIGNARRE, P. Comment la depression est devenue une epidemie. Paris: Hachette, 2001.

RICHET, C. La selection humaine. Paris: Baliere, 1922.

ROSE, S. Trayectorias de vida: biologia, libertad y determinismo. México: Granica, 2001.

SERPA, O. D. Dégénérescence. In: ANDRIEU, B. (org.). Dictionaire de corps dans les sciences humaines et sociales. Paris: CNRS, 2006.

SOUZA, V. S. et al. Arquivo de antropologia física do Museu Nacional: fontes para a história da eugenia no Brasil. História, Ciências, Saúde-Manguinhos, 16(3): 763-777, 2009.

STEPAN, N. L. "A hora da eugenia”": raça, gênero e nação na América Latina.

Rio de Janeiro: Fiocruz, 2005. 


\section{"AgressividAdE" E "VIOLÊNCIA": A DIFÍCIL TAREFA DE CONCEITUAR NO DIÁLOGO ENTRE GENETICISTAS E CIENTISTAS SOCIAIS}

Gláucia Silva

\section{Introdução}

A existência de uma visão sobre o Homem, denominada de "estratigráfica" por Clifford Geertz, parece ser um dos entraves para a possibilidade de diálogo entre a biologia e as ciências sociais, como a análise aqui esboçada pretende evidenciar. Geertz (1978), utilizando a metáfora de um Homem formado por estratos, sistematizou os impasses da interdisciplinaridade de forma bastante clara:

As tentativas de localizar o homem no conjunto dos seus costumes assumiram diversas direções, adotaram táticas diversas; mas todas elas, ou virtualmente todas, agiram em termos de uma única estratégia intelectual ampla: a que eu chamarei, de forma a ter uma arma a brandir contra ela, de concepção "estratigráfica" das relações entre os fatores biológico, psicológico, social e cultural na vida humana. De acordo com essa concepção, o homem é composto de "níveis", cada um deles superposto aos inferiores e reforçando os que estão acima dele. À medida que se analisa o homem, retira-se camada após camada, sendo cada uma dessas camadas completa e irredutível em si mesma, e revelando uma outra espécie de camada muito diferente embaixo dela. Retiram-se as variegadas formas de cultura e se encontram as regularidades estruturais e funcionais da organização social. Descascam-se estas, por sua vez, e se encontram debaixo os fatores psicológicos. 
[...] Retiram-se os fatores psicológicos e surgem então os fundamentos biológicos - anatômicos, fisiológicos, neurológicos - de todo o edifício da vida humana. [...] O atrativo dessa espécie de conceitualização, além do fato de ter garantido a independência e soberania das disciplinas acadêmicas estabelecidas, era parecer tornar possível ter o bolo e comê-lo. (Geertz, 1978: 49)

A "violência" é um desses temas que, tendo um equivalente no comportamento de animais - a "agressividade" -, se torna objeto de pesquisa de cientistas da sociedade e da natureza. Para lidar com esse problema optei, acolhendo a gentil sugestão de Ricardo Ventura Santos, a quem muito agradeço por isso, por me referir basicamente a dois artigos sobre a violência: A biologia na violência, do médico Renato Zamora Flores, e $A$ violência dramatiza causas, da socióloga Maria Cecília de Souza Minayo. A escolha dos textos se explica porque, dialogando ao enfrentarem o tema da violência, eles evidenciam ao mesmo tempo a importância da interlocução entre ciências sociais e ciências naturais e a sua impossibilidade, já que partem de premissas tão díspares entre si.

A questão central no presente trabalho diz respeito a um vastíssimo espectro de questionamentos identificado pela dicotomia natureza/cultura, que funda a disciplina antropológica e, ao contrário de mostrar evidências de fadiga ou extinção, se multiplica em infinitas novas questões afins. Escolher dois artigos para discuti-la é uma maneira de circunscrevê-la e torná-la manuseável. Mas a grande desvantagem é que se corre o risco de pessoalizar a discussão. Não tenho a pretensão de me posicionar de forma "neutra" pois, sendo uma cientista social, tendo a endossar os argumentos desenvolvidos no artigo de Minayo. Entretanto, considero o de Flores extremamente instigante, uma vez que abre espaço para a interlocução com os cientistas sociais. As considerações críticas, aqui orientadas para o artigo A biologia na violência, nada têm de pessoal já que, em trabalho de maior fôlego, poderiam ser endereçadas às disciplinas das 
quais o autor, no Brasil, se tornou um representante. Além disso, fica evidente o louvável intento do autor em contribuir para soluções de problemas sociais agravados em tempos recentes.

\section{1 - As premissas de cada artigo}

Para Minayo (2003), qualquer esforço de compreensão sobre o fenômeno da "violência" exige inicialmente sua qualificação perante a pluralidade de sentidos que um ato de violência pode assumir no contexto em que acontece. Assim - como Héritier (1996) -, prefere falar de "violências", cuja multiplicidade de significados impossibilita sua equivalência estrita à "delinquência", preocupação central do trabalho de Flores (2002).

A autora reconhece que atualmente o tipo de violência que atinge a sensibilidade da opinião pública dos brasileiros é aquela produzida pela conjunção entre criminalidade e delinquência social. Minayo considera que uma importante característica desse tipo de violência no Brasil é "seu caráter infrapolítico ou apolítico", por se tratar de uma violência sem ideologia (Minayo, 2003: 33). Concorda com a ideia de que tais "crimes são fruto da velocidade da circulação financeira e que a delinqüência pós-moderna segue a mesma lógica da globalização, realizando-se em conluio com a legalidade" (Minayo, 2003: 33). Conclui que uma importante condição para o aumento desse tipo de violência é "a promiscuidade entre legalidade e ilegalidade" (Minayo, 2003: 33). Minayo, apoiando-se em Hannah Arendt, entende a violência como um veículo, um sintoma, uma manifestação de alguma causa que só pode ser estudada no contexto de casos específicos, já que se nutre de fatos políticos, econômicos e sociais, ligando aspectos subjetivos com históricos. A diversidade de sua expressão, entretanto, não impede que propriedades comuns a toda forma de violência possam ser reconhecidas. Assim, esta revela conflitos de autoridade, luta pelo poder ou ainda domínio e aniquilamento do outro. 
Para Flores (2002), o fundamental para o entendimento da violência como fenômeno não é qualificá-la ou contextualizá-la, mas compreendê-la como uma resposta adaptativa da espécie humana; admitindo, com a psicologia evolutiva, o funcionamento da cognição humana como análogo ao de um computador, o autor considera que os seres humanos não são dotados, entretanto, de uma capacidade geral para o processamento de qualquer tipo informação. Flores acredita que o cérebro humano teria sido moldado seletivamente num tipo de sociedade, presumivelmente existente no pleistoceno, formada por um restrito número de pessoas reunidas em diversos bandos. Nem todo cérebro humano estaria pronto a processar informações atuais, isto é, adaptado às exigências da sociedade contemporânea, o que gera, a seu ver, um descompasso entre realidade social e comportamento esperado.

Assim, o que Flores denomina de "violência", "agressividade", "comportamento violento", "delinquência", "criminalidade violenta", "comportamento criminal" ou ainda "comportamento criminalizável" seria, em grande parte dos casos, uma "doença mental" causada por essa dificuldade em processar informações características da "sociedade contemporânea" por um cérebro ainda adaptado a uma "sociedade mais simples". Argumenta que, embora exista uma predisposição genética para a "violência", sua existência não acarreta, por si só, sua manifestação. Flores salienta que não há uma relação causal entre genes e comportamento, porque os genes não são a matéria bruta da evolução e sim os comportamentos, por serem fenótipos.

Na visão de Flores, a "doença mental", denominada "transtorno de personalidade antissocial", pode resultar então de uma anomalia no processamento de informações, já que frequentemente acomete pessoas que foram, em algum momento de suas vidas, agredidas e, graças à combinação disso com tal herança genética outrora adaptativa, tendem a dar respostas violentas ("agressão defensiva") como resultado de uma percepção exagerada desenvolvida a partir 
da agressão antes sofrida (Flores, 2002: 201). Em outras palavras, essas pessoas exibem uma excessiva sensibilidade a situações em que se sentem ameaçadas não porque exista, necessariamente, algum risco, mas processam as informações como se ele fosse real e reagem defensivamente com agressividade. Então, a interação entre genética e meio desfavorável aumenta a chance de se desencadear o "transtorno de personalidade antissocial".

Além das diferentes maneiras de definirem o fenômeno da violência, a falta de precisão conceitual, observável na franca utilização de expressões como "instintos sociais" e "tendências mentais", é outra diferença notável entre os dois artigos, já que Minayo mantém constante vigilância no sentido de definir os conceitos utilizados no desenvolvimento de sua análise.

A diversidade do fenômeno da violência não tem para Flores uma importância heurística, embora em dada altura de seu texto se refira à existência de "formas de violência". Para ele, a pluralidade de formas constitui-se de uma única realidade, que é a encontrada nos mecanismos cerebrais; a polissemia do termo fica reduzida a um efeito secundário.

\section{2 - A definição do que seja "fenômeno complexo"}

A complexidade de um sistema deve-se à emergência de novas propriedades não encontradas em suas partes. Assim, Minayo não está preocupada em detectar uma ou várias causas da violência. Ao contrário, mostra como é uma tentativa fadada ao fracasso se a violência não for entendida como um fenômeno extremamente variado, produzido no encontro de diversas dimensões, que vão das mais subjetivas e individuais às mais gerais, de ordem histórica, social, política e econômica. Por isso, a violência é ao mesmo tempo específica e complexa. A especificidade diz respeito ao acontecimento concreto e sua temporalidade: a violência só pode ser estudada se relacionada ao(s) contexto(s) em que seu processo se desenrola. Sua 
complexidade se deve ao fato de não ser explicada por uma relação causa/efeito.

Para Flores, a complexidade, mesmo não estando totalmente ausente da dimensão biológica, é, sobretudo, uma propriedade da sociedade. A complexidade inerente ao "comportamento violento" é devida à mediação de um ambiente social que atua como um provocador do mecanismo de funcionamento cerebral: "a violência familiar aumenta o risco de doença mental na família" (Flores, 2002: 200). A predisposição genética para a doença mental que desencadeia a violência, sob influência de meio desfavorável, seria uma de suas causas primárias. Atribuindo, conforme acabou de ser dito, um menor nível de complexidade aos fenômenos biológicos do que aos fenômenos sociais, considera então que aqueles constituem as causas primárias destes; conclui, pois, que, sendo os fenômenos sociais dependentes dos biológicos, devem ser explicados por estes últimos.

Flores, então, admite que considerar causas primárias ou hierarquicamente mais relevantes no desencadeamento do comportamento violento não é contraditório com o fato de concordar com Minayo que "a violência" é um fenômeno complexo. Afinal, a "mente", a "cognição", os "instintos sociais", independentemente de suas definições, existiriam graças ao funcionamento cerebral. Flores sustenta que o que aparenta ser reducionismo aos olhos dos cientistas sociais é, na verdade, um modo hierárquico e "não reducionista" de lidar com sistemas complexos. $\mathrm{O}$ autor persevera em uma argumentação, a meu ver, ambígua, na qual, ao mesmo tempo que defende o caráter científico tanto do reducionismo metodológico quanto do determinismo, refuta que essas características possam ser atribuídas ao seu trabalho. Ele acredita que considerar o cérebro como mediador do processo de desencadeamento de um "comportamento violento" seja suficiente para a superação das explicações fundamentadas num determinismo genético mais elementar. 
Mas, se, por um lado, o reducionismo pode ser eventualmente adotado como método, a simplificação e a utilização fluida de conceitos servem apenas para frustrar qualquer tentativa de diálogo interdisciplinar. O que se depreende da argumentação de Flores é que a violência como objeto de pesquisa pode ser totalmente explicada no âmbito de sua área de atuação, dispensando a contribuição das ciências sociais.

\section{3-A difícil tarefa de conceituar: a natureza da natureza humana, o evolucionismo e o atavismo}

Chama a atenção, no texto de Flores, a valorização de temas que, podendo ter raízes ainda mais antigas, ganharam uma feição característica no cenário intelectual do século XIX, tais como "natureza humana", "evolucionismo social" e "atavismo". Isso pode ser explicado, pelo menos em parte, pela hegemonia do darwinismo nas ciências biológicas, graças ao grande sucesso explicativo que a ideia de seleção natural (Darwin, 2004a) alcançou, tendo sido aplicada, desde seu surgimento, aos vários níveis biológicos: molecular, citológico e ecológico.

(a) Embora Flores afirme não acreditar na existência de uma "natureza humana imutável", crê na existência de instintos humanos (ou instintos sociais), o que pode ser entendido como uma natureza humana que passou por um processo de seleção natural. A nova natureza humana é passível de transformação na medida em que responde a esse processo seletivo, e alguns de seus aspectos, tal como a "agressividade", são encontrados em outras espécies sociais (as de primatas, por exemplo). Assim, o autor muda a natureza dessa natureza, mas ela permanece como substrato orgânico da vida social.

É a crença nessa natureza humana, o nosso "estrato mais interior", ao mesmo tempo "animal" e "social", que permite que Flores torne equivalentes os termos violência e agressividade, tema importante para os estudiosos da área "psi", a etologia estando aí compreendida. 
A leitura do artigo de Flores convida à pergunta: se a agressividade é um comportamento selecionado naturalmente, estaria a sociedade indo contra sua própria natureza ao condenar, por exemplo, os menores infratores que vivem em regime de restrição de liberdade por ele ${ }^{1}$ estudados? É possível depreender do texto que o que fez com que certos "comportamentos", outrora adaptativos, se tornassem atualmente desajustados e "doentios" foi a evolução social (ou civilização), desdobramento natural do processo de hominização. ${ }^{2}$

(b) Conforme já foi dito, para Flores, a "doença mental" que desencadeia a delinquência é o resultado de uma predisposição genética "selecionada" na época em que o "comportamento agressivo/ violento" foi adaptativo, porque era uma maneira adequada ao processamento do conjunto de informações daquele contexto da história evolutiva humana. No pleistoceno, teria sido uma vantagem evolutiva a capacidade de os indivíduos discriminarem entre "nós" e "eles", devido à alta frequência de supostas disputas por território, alimento e mulheres. Atualmente, entretanto, tal "conduta" passa a ser vista como uma incapacidade de processamento adequado dos novos dados porque reproduz, em área urbana e "civilizada", o que teria ocorrido em um contexto possivelmente bastante próximo daquele que foi, na filosofia, denominado de "estado de natureza". Para Flores, essa tendência de separar "nós" e "eles" foi certamente adaptativa nos primórdios do Homo sapiens porque o grupo era defendido por uma espécie de instinto coletivo presente em cada indivíduo: "É bastante mais fácil odiar os inimigos do que amá-los ou de perdoá-los, e isto, independentemente da opção moral de cada um, é uma realidade decorrente da seleção natural" (Flores, 2002: 201).

\footnotetext{
1 Como médico, Flores dirigiu um projeto sobre "criminalidade violenta" e realizou uma pesquisa com menores infratores que vivem em regime de restrição de liberdade em uma instituição do Rio Grande do Sul (Flores, 2002: 199).

2 Para uma excelente crítica a essa visão, ver Ingold (2006).
} 
A seleção natural atuaria também na sociedade, ou através dela; por isso, Flores alerta os cientistas sociais de que "nada faz sentido em sociologia, senão à luz da evolução" (Flores, 2002: 202), mostrando-se um franco adepto do evolucionismo social, ou falso evolucionismo, nas palavras de Lévi-Strauss (1976a; 1976b).

A ideia de que há uma permanência de disposições cognitivas selecionadas em épocas primitivas da humanidade parece aproximar Flores de pensadores vitorianos que consideravam "sobrevivências" aquelas práticas sociais "exóticas" cujo significado desconheciam. Imaginavam que, embora tivessem perdido sua função social ao longo do tempo, tais práticas se mantinham pela força do hábito. No século XIX, essa era uma visão importada por pensadores - alguns deles hoje reconhecidos como fundadores da antropologia social/ cultural - dos estudos comparados de embriologia e anatomia, que embasavam a afirmação de que a existência de estruturas orgânicas vestigiais, tais como apêndice e os últimos molares, ilustravam, como se lê no primeiro capítulo de $A$ origem do homem (Darwin, 2004b: 13-51), a evidência de uma origem comum das espécies e, portanto, do surgimento de uma espécie mais apta a partir de outra.

(c) Flores, ao biologizar as causas do que denomina comportamento criminal/criminalizável ou delinquente, reedita, embora de forma mais refinada, facetas do atavismo, teoria de Cesare Lombroso, médico italiano criador da antropologia criminal que tentou mudar o pensamento jurídico de seu tempo afirmando que o "caráter hereditário do crime" deveria embasar sentenças que levassem em conta o criminoso e não o ato em si. Em um dos trabalhos extremamente valiosos de Stephen Jay Gould (2003), há uma excelente análise a esse respeito, na qual me baseio a seguir, embora de forma sucinta.

Tratava-se de uma teoria evolucionista, já que os criminosos seriam tipos atávicos, do ponto de vista da evolução, que perdurariam entre nós tais como as "sobrevivências" dos evolucionistas vitorianos. Segundo Lombroso, em nossa hereditariedade, permaneceriam ger- 
mes em estado letárgico provénientes de um passado ancestral. Em alguns indivíduos - humanos ou não (formigas e castores poderiam integrar a lista) -, esse passado poderia "vir à tona". Para Lombroso, um criminoso seria comparável a um selvagem que surgisse na sociedade moderna; assim, em 1887, concluiu que atavismos equiparavam o criminoso europeu aos indivíduos - não criminosos - de origem australiana e mongólica (Gould, 2003: 41). O atavismo, dessa forma, apoia-se em um argumento bastante próximo ao da recapitulação (Gould, 2003: 126), teoria amplamente aceita e também trabalhada por Darwin (2004b: 13-28).

Lombroso nunca atribuiu todos os atos criminosos a pessoas com estigmas atávicos. Estimou que uns $40 \%$ dos criminosos obedeciam a uma compulsão hereditária, enquanto outros atuavam movidos pela paixão, pela fúria ou pelo desespero. Um homem com estigmas comete crimes movido por sua natureza inata; outro, sem estigmas, pela força das circunstâncias (Gould, 2003: 130). Também Flores não diagnosticou, em sua pesquisa, como portadores do transtorno de personalidade antissocial, mais que $40 \%$ dos 560 adolescentes incluídos em sua amostra (Flores, 2002: 198). Acreditando que um diagnóstico precoce de um estigma poderia evitar o surgimento de um "criminoso", Lombroso sugeria que um isolamento prematuro em lugares bucólicos poderia mitigar essa tendência inata e assegurar uma vida útil sob contínua supervisão (Gould, 2003: 140). Comparavelmente, o interesse de Flores é mostrar que, sendo a violência um problema médico, tratado como doença na origem, não se transforma em problema social.

A ideia de Stephen Jay Gould, em seu magistral $A$ falsa medida do homem, é discutir o bias que sustenta os experimentos científicos que objetivam evidenciar a superioridade de uns em relação a outros. Esse foi o caso da craniometria, que tentou provar a superioridade da "raça branca" e dos testes de quociente de inteligência, pilares de um grande movimento de reificação de características humanas que 
impregnaram fartamente o pensamento científico do século XIX, e com o qual ainda se convive, como se lê no trecho abaixo:

Vivemos num século mais sutil, mas os argumentos básicos parecem nunca mudar. As toscas avaliações do índice craniano foram substituídas pela complexidade dos testes de inteligência. Os sinais de criminalidade inata não são mais procurados em estigmas anatômicos, mas em critérios próprios do século XX: nos genes e nas delicadas estruturas cerebrais. (Gould, 2003: 144)

Mas o intuito de Flores está longe de ser o de distinguir hierarquicamente contingentes humanos superiores de inferiores. Seu intuito é o de tentar provar que o fenômeno da violência pode ser explicado pelo reconhecimento de patologias. Com relação a essa questão, Gould, paleontólogo e importante divulgador do darwinismo, considerou:

As populações humanas apresentam uma grande variedade de comportamentos; o simples fato de alguns manifestarem certa conduta e outros não, não constitui prova alguma de que o cérebro dos primeiros padeça de alguma patologia específica. (Gould, 2003: 146)

É ainda possível encontrar no artigo em foco outro ponto de contato com a obra de Lombroso. Flores também considera que a biologia pode contribuir, via evolução, para as teorias jurídicas:

O conhecimento biológico trará profundas mudanças ao pensamento jurídico, quando puder alcançá-lo. Por exemplo: como os instintos sociais humanos não foram desenvolvidos para uma sociedade como a nossa e sim, para a convivência com pequenos bandos, o direito deve levar em conta que a estrutura mental humana predispõe os indivíduos a certas regras epigenéticas de pensamento. Por exemplo: a grande maioria das agressões humanas ocorre em um contexto mental no qual o indivíduo que agride sentiu-se previamente agredido. Das diferentes formas de 
agressão interespecífica que ocorrem entre animais, a mais relevante para o entendimento da violência é a agressão defensiva, modulada positivamente pela amígdala e, negativamente, por regiões do hipotálamo. (Flores, 2002: 201)

Acredito ter ficado claro que parte da incompatibilidade entre os instrumentais teóricos das ciências naturais e sociais se deve à permanência, no debate acerca das sociedades humanas, de ideias que, tendo integrado um dia o arcabouço conceitual da antropologia e da sociologia, para estas não mais conservam, hoje, seu valor explicativo; já as ciências biológicas, percorrendo caminho distinto, podem dispor da convivência de seu grande desenvolvimento tecnológico com a ideia vitoriana - e vitoriosa - de seleção natural. Parafraseando Marshall Sahlins (1980), o problema está no abuso do conceito.

\section{4 - Antropologia e genômica}

A dificuldade de diálogo entre a biologia e as ciências sociais, observada por Ingold, se amplia quando o diálogo é tentado entre um cientista social e um representante da aplicação do darwinismo na sociedade. Isso desestimulou os cientistas sociais a buscar uma interlocução, quadro que vem se revertendo com o surgimento da nova genética ou genômica, designação dada para o ramo de estudos que geneticistas e bioquímicos vêm desenvolvendo sobre o código genético e que traz expectativas sobre a possibilidade de uma imensa gama de inovações tecnológicas. Rabinow (1999) acredita que a genômica venha a ocasionar uma completa mudança na maneira de se pensar limites entre natureza e cultura. Também para Gisli Palsson (2007), ela se apresenta como um desafio para a antropologia que, segundo o autor, deve:

[...] se engajar criticamente nos estudos da Genética e refletir sobre o conhecimento histórico e comparativo da disciplina, sua compreensão das espécies, e as implicações da genômica sobre o que significa ser humano na idade moderna. (Palsson, 2007: 208) 
Ao reconhecer com justeza que a genômica confronta antigas dualidades, Palsson (2007) é entretanto excessivamente otimista com relação ao poder de previsão das ciências sociais:

No futuro, a nova genética cessará de ser uma metáfora para a sociedade moderna e se transformará numa rede de circulação de termos de identidade e lugares restritos, ao redor do qual e através do qual um verdadeiro novo tipo de autoprodução emergirá e que eu chamo de biossocialidade. (Palsson, 2007: 212)

O que o futuro reserva em termos de mudanças sociais é sempre um enigma. O presente da genômica é certamente rico com a multiplicidade de áreas que abrange. Conforme Santos observa com outros autores (Santos et al., 2009), essa nova frente de pesquisa ganha crescente influência nas áreas da saúde e das tecnologias voltadas para a reprodução, adquirindo também importância em contextos nos quais movimentos sociais voltados para construções identitárias interagem com informações biológicas que ora reafirmam ora contradizem suas próprias concepções.

Concordando com Palsson, a crítica dos cientistas sociais pode ser bem-vinda ao empreendimento genômico no sentido de, por exemplo, explicitar a subjetividade presente na construção de amostras por parte dos geneticistas, ou analisar a prática desses cientistas cujas descobertas intentam muitas vezes alterar a forma como grupos sociais se pensam, se definem e se comportam, ou ainda, na adoção de noções tais como "miscigenação".

A ideia de miscigenação subsistir à de raça no seio da genética é um interessante ponto de reflexão para antropólogos e sociólogos. Há povos mais endogâmicos que outros, há aqueles que cultivam a xenofobia e há os que não marcam ou valoram o fato de serem "misturados". A "mistura" parece ser um valor positivo para os brasileiros em diversos contextos, e a percepção da existência dessa "mistura" parece ser uma característica claramente cultural. Os antropólogos podem se perguntar em que medida os geneticistas, cuja tendência tem 
sido a de dissolver noções substantivas como "raça", ao manterem em seu ideário a noção de "miscigenação", tomam traços culturais como parâmetros genéticos. Por que privilegiar a "miscigenação" moderna, oriunda de casamentos, possíveis apenas num contexto de colonização, como um marco especial de miscigenação genética?

Uma outra contribuição inovadora trazida pela genômica é a possibilidade de questionar as bases do darwinismo embutido na teoria sintética. A genômica, indo além de se restringir a responder, com incremento de tecnologia, questões formuladas ainda no quadro conceitual do século XIX, como parece fazer a psicologia evolutiva, reacende o debate acerca da herança dos caracteres adquiridos, com novo enfoque, ao estudar mutações no DNA denominadas epigenéticas. ${ }^{3}$ Estas não só ocorrem de forma orientada por um mecanismo de retroalimentação entre núcleo das células e meio externo, como são, ainda, passadas à descendência. Abrir espaço para verificar a importância desse tipo de mutação para os mecanismos de evolução e seleção natural constitui um afastamento do que veio sendo admitido ser o legado de Darwin ao longo do século passado; ou, pelo menos, a contribuição darwinista assumida pela teoria sintética.

Embora isso seja menosprezado pela teoria sintética, Darwin concebia a evolução como um processo que combina mutação ao acaso com as duas leis conhecidas como lamarckistas - "uso e desuso" e "herança dos caracteres adquiridos" -, como escreve em seu livro A origem do homem e a seleção sexual, do qual foram extraídos os dois trechos abaixo:

Para poder compreender a origem de órgãos rudimentares, não caberia supor senão que os antepassados primitivos da espécie deviam possuir partes em questão num estado perfeito, e que, com a mudança dos hábitos e costumes, estes se foram reduzindo pouco a pouco, seja pelo simples desuso, seja pela seleção

3 As interações epigenéticas são estudadas por um ramo da biologia de mesmo nome e são constituídas por um processo de metilação do DNA. 
natural, dos espécimes dotados de menor quantidade de partes supérfluas somadas ao concurso de outros agentes mencionados anteriormente. (Darwin, 2004b: 28)

$[\ldots]$ certas ações inteligentes - como as das aves que vivem nas ilhas oceânicas e que aprendem a fugir dos homens - depois de ser executadas durante muitas gerações, acabam convertendo-se em instintivas ou hereditárias. (Darwin, 2004b: 31)

A genômica traz então a possibilidade de se pensar que a teoria sintética fechou em sua caixa preta (para usarmos um termo trabalhado por Latour (2000) uma interpretação de Darwin, dentre várias possíveis. Parece que o campo da biologia tem se unificado sob um rótulo que vai ficando cada vez mais vestigial: a ideia de seleção natural permanece, porém, despida de algumas de suas marcas originais.

\section{5 - Considerações finais ${ }^{4}$}

Pode-se afirmar que mesmo que as conclusões por demais simplificadoras dos biólogos que se voltam para o entendimento das sociedades - humanas - não convençam - com razão - os cientistas sociais, elas não deixam de apontar para uma questão imensamente importante, que é a da dupla classificação humana: animal e social. Como todas as taxonomias, essas categorias classificatórias - social, animal - são sistematizadas a partir de valores (Dummont, 1966), e a radicalidade da especificidade humana, que é sua duplicidade, depende dos valores/critérios que informam a classificação. Darwin (2004a, $2004 b, 2009)$ teve que fazer um grande esforço para enfrentar a ideia de criação especial e mostrar que a espécie humana descende de outras menos evoluídas, inserindo-se assim numa série natural. ${ }^{5}$ Seu intento era mostrar que a distância entre a humanidade e a animalidade era de grau. As ciências sociais foram então assumindo a posição de herdeiras

\footnotetext{
4 As considerações expostas nessa seção também podem ser encontradas em Silva (1993
e 2006).

5 Lineu já havia classificado, mas Darwin teorizou sobre o processo.
} 
da visão antropocêntrica que o cristianismo, como bem mostra Keith Thomas (1988), cultivou; as ciências sociais trabalham assim com uma distinção de natureza entre homens e demais animais.

Recentemente, o antropocentrismo da antropologia, que tanto incomoda os biólogos, começou a soar estranho também para os próprios antropólogos porque nele reconheceram um traço que, como o etnocentrismo que informou o surgimento da disciplina, pode estar emperrando seu refinamento. Como exemplo desse estranhamento há os trabalhos de Tim Ingold, antropólogo britânico, que levanta a questão da animalidade do Homem de uma forma bastante pertinente $(1995,2006,2007)$. Ele afirma que enfatizar a singularidade da condição humana não é por si só uma postura antropocêntrica. É a radicalidade da distinção que manifesta um antropocentrismo, e não a distinção em si.

Os antropólogos nem sempre se preocuparam com contribuições externas à disciplina. A relação das ciências sociais com as da natureza já foi marcada pela importação de modelos explicativos da matemática, da física e da biologia, numa tentativa de legitimação perante estas últimas, como analisa Philippe Descola (1988), sem que, entretanto, fosse criado um diálogo. Mesmo que a importação parcial desses modelos pareça já ter dado todos os frutos ou que a imposição de seus próprios modelos e termos, por parte dos biólogos, para a explicação de fenômenos sociais mostre-se reducionista e essencializadora, a reflexão sobre a "animalidade do Homem" (ou a natureza humana), como nos ensina o já mencionado Tim Ingold, continua atual.

Apoiado em outros autores, Ingold sustenta que assim como os habitantes das sociedades tribais da África, Américas e Oceania tiveram, no passado, seu pertencimento à humanidade questionado pelos primeiros estudiosos do assunto, os animais podem estar sendo vítimas de um movimento análogo. No primeiro caso tratava-se de etnocentrismo, mas no segundo trata-se de antropocentrismo, que, 
criando uma descontinuidade entre os humanos e os não humanos, não admite a existência de atributos humanos - tais como formas de linguagem, engenhosidade e inteligência - em outros animais.

Para Ingold, poderíamos trocar a fratura que separa radicalmente a humanidade da animalidade por uma escala que gradualmente as ligasse. E se pergunta: "a natureza humana reside em nossa animalidade ou em nossa humanidade?". Insistir em responder à pergunta é recusar-se a superar a dicotomia. Para ele nem as ciências humanas são as únicas que podem explicar as culturas, nem as ciências naturais sozinhas podem dar conta de compreender as outras formas de vida e os universos dos animais não humanos.

\section{Referências}

DARWIN, C. A origem das espécies. São Paulo: Martin Claret, 2004a. A origem do homem e a seleção sexual. Belo Horizonte: Itatiaia, 2004b. A expressão das emoções no homem e nos animais. São Paulo: Cia das Letras, 2009.

DESCOLA, P. 'L'explication causale'. In: DESCOLA, P. et al. Les idées de l'anthropologie. Paris: Armand Colin, 1998.

DUMMONT, L. Homo hierarchicus. Paris: Gallimard, 1966.

FLORES, R. Z. A biologia na violência. Ciência \& Saúde Coletiva, 7: 197202, 2002.

GEERTZ, C. A interpretação das culturas. Rio de Janeiro: Zahar, 1978.

GOULD, S. J. A falsa medida do homem. São Paulo: Martins Fontes, 2003. HERITIER, F. De la violence. Paris: Odile Jacob, 1996.

LATOUR, B. Ciência em ação: como seguir cientistas e engenheiros sociedade afora. São Paulo: Unesp, 2000.

LÉVI-STRAUSS, C. O pensamento selvagem. São Paulo: Nacional, 1976a. . Antropologia estrutural dois. Rio de Janeiro: Tempo Brasileiro, 1976b. MINAYO, M. C. S. A violência dramatiza causas. In: MINAYO, M. C. S. (org.). Violência sob o olhar da saúde: a infrapolítica da contemporaneidade brasileira. Rio de Janeiro: Fiocruz, 2003. 
INGOLD, T. Humanidade e animalidade. Revista Brasileira de Ciências Sociais, 28: 39-54, 1995.

Sobre a distinção entre evolução e história. Antropolítica: Revista Contemporânea de Antropologia, 20: 17-36, 2006.

. Introdução. O que é um animal? Revista Contemporânea de Antropologia, 22: 129-150, 2007.

PALSSON, G. Anthropology and the new genetics. Cambridge: Cambridge University Press, 2007.

RABINOW, P. Antropologia da razão. Rio de Janeiro: Relume Dumará, 1999.

SAHLINS, M. Critique de la sociobiologie: aspects anthropologiques. Paris:

Gallimard, 1980.

SANTOS, R. V. et al. Color, race and genomic ancestry in Brazil: dialogues between anthropology and genetics. Current Anthropology, 50: 787-820, 2009. SILVA, G. O que é sociobiologia. São Paulo: Brasiliense, 1993. (Coleção Primeiros Passos)

A sociobiologia e a crítica dos antropólogos. ComCiência, Revista Eletrônica de Jornalismo Científico, 80: 3, 2006.

THOMAS, K. O homem e o mundo natural. São Paulo: Cia das Letras, 1988. 


\section{SAÚDE, LONGEVIDADE E GENÉTICA: UM OLHAR BIOPOLÍTICO}

Luis David Castiel

\section{Apresentação}

Diante da crucial pergunta acerca de qual é a receita para uma longa vida não faltam respostas e fórmulas originárias dos saberes populares. Uma variedade de práticas alimentares e atividades físicas são consideradas, sem a autoridade do dispositivo empírico-lógico científico para sustentá-las em termos de uma suposta efetividade. Ainda assim, há algo de pertinência que inclui aspectos de hereditariedade parental nos julgamentos de longevidade dentro da respectiva família.

Por sua vez, os saberes científicos trazem respostas a esta pergunta a partir da operação de tal dispositivo - como não poderia deixar de ser, por meio de achados de pesquisas realizadas sobretudo pelas ciências epidemiológicas e biomédicas (onde se incluem as abordagens genéticas).

Tais resultados, uma vez corroborados, assumem o lugar de evidências que devem ser incorporadas aos modos de vida das pessoas tendo em vista a promoção da saúde. Sua meta, a rigor, é alcançar a máxima longevidade possível, com vitalidade passível de ser mantida. E também consumida, pois, inevitavelmente, também se trata de uma faixa de mercadorias no âmbito dos produtos, serviços, tecnologias no campo da atenção curativa e preventiva à saúde, portanto acessível seletivamente aos que possuem poder aquisitivo para o consumo. Brevemente, esta é a paisagem apresentada de modo bastante esquemático de como a questão da longevidade pode ser considerada na época atual. 


\section{Saúde, longevidade e genética}

Se, por exemplo, colocarmos a expressão "longevity" no buscador Google, teremos 75.200 .000 resultados (em 30/08/2010). Ainda que tosco, não deixa de ser um indicador do alcance de como a questão se apresenta na grande rede em sua relação com a atenção social representada pela oferta e procura daqueles com acesso à internet.

Um dos portais que aparecem na primeira página dessa busca é o http://www.longevitymeme.org (Portal Fight Aging, 2011). Desde logo se destaca a discutível noção de meme criada em 1976 por Richard Dawkins (1976) como unidade de herança cultural que reside no cérebro, como circuitos neurais. $\mathrm{O}$ conceito proliferou e atualmente há livros, portais de internet e conferências acadêmicas dedicadas ao tema. Todas tratam de um novo replicador que mimetiza os genes - "velhos replicadores" que se constituem como um padrão de informação transmissível ou copiado da memória de uma pessoa a outra, podendo até assumir aspectos epidêmicos.

Jablonka e Lamb (2005) consideram seus pressupostos equivocados em função da confusão feita entre replicadores e seus veículos - os cérebros humanos, artefatos humanos ou os próprios humanos -, que não podem transmitir as variações adquiridas de geração a geração.

Aqui, importa enfatizar que o portal assume a noção "científica" de "meme da longevidade" como a "coleção de ideias, pontos de vista e comportamentos que irão capacitar a pessoas a levar vidas longas, saudáveis e estendidas" (Portal Fight Aging, 2010a).

Isto está de acordo com a proposta de replicação e difusão da noção de longevidade tal como apresentada no portal. Ou seja, mediante uma retórica triunfalista científico-religiosa que comodifica o produto saúde e visa ser a dominante no campo das práticas preventivas de saúde. Nesse sentido, destaca-se um texto que representa, sem meias palavras, o processo de envelhecimento sob um ponto de vista próprio de muitas proposições de promoção de saúde bélica- 
-persecutórias que, de certa forma, apresentam traços compatíveis com uma guerra santa:

Envelhecer é um inimigo. Sabota nossa força e capacidade de desfrutar a vida, nos torna deficientes e finalmente nos mata. Dezenas de milhares morrem de condições relacionadas ao envelhecimento cada ano. Comparativamente poucas pessoas sabem que o envelhecimento degenerativo pode ser modestamente desacelerado com escolhas de dieta e estilo de vida, como é o caso de muitas condições médicas. Comparativamente, poucas pessoas estão conscientes de que sérios esforços científicos estão sendo realizados atualmente com vistas a entender e intervir no processo de envelhecimento - com o propósito de reverter seus efeitos.

Um dia, cientistas irão encontrar um modo de derrotar o envelhecimento. Gostaríamos que esta descoberta acontecesse enquanto estivéssemos vivos e em boa saúde para que nos beneficiássemos disto. Como alcançaríamos esta meta? Leia a seguir para descobrir. Então, temos 3 passos que são explicados com mais detalhes, mas cujos títulos permitem entrever os respectivos conteúdos: 1) pare de prejudicar sua saúde; 2) adote melhores dietas e estilo de vida; 3 ) apoie e advogue a ciência da longevidade. (Portal Fight Aging, 2010b)

Estes passos irão conduzir seus adeptos à “extensão saudável da vida" - ou seja,

[...] o uso da ciência e da tecnologia para aumentar o tempo de vida e reduzir o risco de sofrer condições relacionadas ao envelhecimento nessa fase da vida avançada. E empregar os melhores e mais provados métodos da atualidade, enquanto se apóia a pesquisa para desenvolver métodos mais efetivos para o amanhã. (...) Há muito mais do que simplesmente cuidar de sua saúde aqui e agora. A medicina de hoje pode fazer pouco em comparação com o que os cientistas sabem que é possível e portanto precisamos garantir que o público seja educado, a pesquisa financiada e a medicina do futuro desenvolvida. (Portal Fight Aging, 2010b) 
Mesmo se apresentando como uma instância sem fins lucrativos (Portal Fight Aging, 2010c), o link "resources" indica várias possibilidades de doação. Um deles é a Methuselah Foundation, que emprega uma retórica nitidamente utilizada por igrejas evangélicas que infestam os meios de comunicação, e a promessa, ancorada na luz da ciência, é a... vida mais eterna possível para mortais:

Imagine-se vivendo 120 anos saudáveis. Somente 73 lugares dos 300 que restam. Junte-se aos 300: o movimento para terminar com as doenças relacionadas ao envelhecimento de uma vez por todas. Sua doação livre de impostos irá ajudar a garantir que seus amigos e entes queridos, seus filhos e netos nunca irão conhecer o sofrimento das doenças relacionadas ao envelhecimento. Junte-se aos 300 agora e compartilhe um legado imortal. Seu nome e imagem gravados em um monumento de aço e mármore e seus desejos de um amanhã saudável serão mostrados para sempre. (Portal Methuselah Foundation, 2010)

Além de colaborador para o setor de artigos científicos do portal, Nick Bostrom é o diretor do Instituto para o Futuro da Humanidade da Universidade de Oxford, Inglaterra. Faz menção aos desafios da terapia genética somática para insertar genes benéficos nas células de adultos não apenas para curar doenças hereditárias, mas também para potencialmente compensar as mudanças que ocorrem com o envelhecimento (Portal Fight Aging, 2010d).

Para isso, propõe uma perspectiva ética transumanista em relação a tais aperfeiçoamentos genéticos que irão ampliar a extensão da vida humana, ou seja, promove um enfoque interdisciplinar apara entender e avaliar as oportunidades de aperfeiçoamento da condição humana e do organismo humano abertas pelo avanço da tecnologia. Transumanistas têm a esperança de que, pelo uso responsável da ciência, tecnologia e outros meios racionais, chegaremos finalmente a nos tornar pós-humanos, seres com muito mais recursos que os atuais seres humanos. 
Também colaboradora do portal, a dupla Ray Kurzweil e Terry Grossman produziu um livro lançado em 2005 onde mostra o que deve ser feito e seguido para se obter a longevidade. O título em inglês, Fantastic voyage. Live long enough to live forever (Viagem fantástica - viver muito o suficiente para se viver para sempre), se baseava na obra de ficção científica de Isaac Asimov (que depois se tornou um filme de mesmo nome), na qual ocorre uma viagem, por meio de um microssubmarino tripulado por uma equipe de cinco experts miniaturizados, ao interior do corpo de um homem que estava ameaçado por um coágulo. Há uma edição em português, intitulada A medicina da imortalidade: as dietas, os programas e as inovações tecnológicas que prometem revolucionar nosso processo
de envelhecimento.

Além de reiterarem a mesma expectativa genômica de Bostrom (2003) sobre a disponibilidade de ferramentas para se alcançar a terapia genética somática, os autores declaram que a prioridade atual da genética é alterar a expressão de genes assassinos através do controle dos caminhos metabólicos que afetam nossas proteínas, enzimas e hormônios. A linguagem guerreira não cessa.

$\mathrm{Na}$ atualidade, há serviços oferecidos pela internet cuja finalidade é proporcionar o acesso a informações relativas à longevidade. Pode ser através do preenchimento de questionários, como no caso do site $\mathrm{http} / /$ calculator.livingto100.com/calculator (Living to 100 , 2010), que traz o calculador de expectativa de vida "vivendo até os
100", do Dr. Thomas Perls, professor associado do Centro do Mal de Alzheimer da Universidade de Boston e fundador e diretor do Estudo de Centenários da Nova Inglaterra. Segundo o portal, usam-se dados atualizados provenientes de pesquisas cuidadosas com o propósito
de estimar até que idade o cliente vai viver.

Para isso, o calculador faz 40 perguntas rápidas sobre estilo de vida, doenças existentes, exposição a riscos e história familiar. Posteriormente, o consulente recebe um feedback personalizado, um guia 
de recomendações a serem seguidas com orientações para o clínico do entrevistado e uma lista de indicações que podem ser feitas para alterar hábitos e comportamentos do interessado e a recompensa de quantos anos serão acrescentados uma vez adotadas as medidas. No caso pessoal do autor deste texto, o resultado foi a expectativa de atingir a idade de 88 anos, com a recomendação de associar-se a uma rede social "EONS", de pessoas de idade equivalente, no portal https://www.eons.com.

Outra forma de acesso a informações (genéticas) dirige os interessados para exames de DNA da saliva, viabilizados por uma empresa que envia um kit pelo correio. Há indicações de que esse tipo de empresa de genômica pessoal tem sofrido dificuldades financeiras, com o encerramento de atividades de uma delas - www.decode.com. (Portal Wired, 2010). Mas permanecem os serviços da http://www.navigenics.com/, que oferece análise genética para descobrir predisposições genéticas para condições importantes de saúde e suscetibilidades medicamentosas e provê recursos para auxiliar o cliente e seu médico a entender suas informações genéticas na medida em que desenvolve estratégias personalizadas de saúde (Navigenics, 2010).

Mas, saindo da seara futurológica, o que há, de fato, sobre as possibilidades da genética atual em termos de longevidade?

Antes, porém, cabe mencionar, esquematicamente, enunciados biológicos a respeito das teorias do envelhecimento humano. Todas preconizam correspondentes formas distintas de tratamento para lidar com o processo. Tais teorias, de alguma forma, descendem de outras, e algumas apresentam evidentes interseções entre si:

- Neuroendócrina: focaliza a perda da capacidade regulatória da rede hormonal comandada pelo eixo hipotálamo/hipófise à medida que os anos de vida passam. Os receptores que capturam hormônios específicos se tornariam menos sensíveis a eles. Isto seria compatível com o declínio dos seus níveis secretórios. Essa redução de desempenho hipotalâmico seria atribuída aos efeitos do cortisol, que costuma 
se elevar com a idade e está vinculado aos estados de estresse.

- Radicais livres: postula que qualquer molécula com elétron

extra e, portanto, com maior carga negativa é capaz de ligar-se e reagir com moléculas saudáveis de modo destrutivo, tornando-a também radical livre. Tanto fatores extrínsecos (como dieta, tabagismo, ingestão de álcool, radiação etc.) e intrínsecos (os ciclos produtores de energia, ATP - Adenosina trifosfato, especialmente mitocondriais) interferem neste processo. Os radicais livres são conhecidos por atacar a estrutura das membranas celulares, produzindo resíduos tóxicos que interferem com a comunicação celular e danificam o e prejudicando processos químicos vitais.

- Envelhecimento da membrana: propõe que as alterações celulares que ocorrem com o passar do tempo comprometem a capacidade da célula de transferir substâncias químicas, calor e processos elétricos, com efeitos deletérios para o seu funcionamento. Com o envelhecimento, há perda lipídica das membranas, com aumento de sua solidez e diminuição de suas propriedades de permeabilidade regulatória, dando margem a acumulações de toxinas, chamadas lipofuscinas. Isso ocorre especialmente no cérebro, no coração e também na pele, onde, com a idade, se manifestam como pigmentos compostos por lipofuscina. Sabe-se que pacientes com mal de Alzheimer apresentam depósitos mais elevados deste pigmento se
comparados com grupos controle

- Limite da divisão celular: estabelece o número de vezes que as células poderão se dividir (ao redor de 50 vezes), comprometendo a longevidade celular. Isto ocorreria em função do aumento de resíduos tóxicos intracelulares e dos desequilíbrios nutricionais das células, com estas apresentando uma capacidade de divisão proporcional à sua nutrição.

- Declínio mitocondrial: como brevemente mencionado antes, formula que a função primordial das mitocôndrias é fazer vários 
ciclos químicos para a produção de energia sob a forma de ATP (Adenosina Trifosfato). Diante das necessidades de energia para as ações humanas, a mitocôndria precisa ser bastante eficiente e saudável para manter um fluxo apropriado de ATP, necessário para a manutenção dos processos de reparação e regeneração dos órgãos corporais. Com a idade, as mitocôndrias tornam-se menos eficientes, diminuem em número e aumentam de tamanho, com a queda da produção de ATP, e os órgãos vão perdendo suas capacidades funcionais.

- Glicosilação (também denominada teoria da ligação cruzada - cross linking): veicula a proposição de que a ligação da glicose à proteína (processo que sucede na presença de oxigênio) causa vários problemas. Uma vez que tal ligação aconteceu, a proteína se torna prejudicada e incapaz de desempenhar suas funções eficientemente. Com o passar dos anos, estes eventos seriam capazes de gerar desordens como catarata senil, espessamento e amarelamento da pele, diabetes senil, aumento cardíaco, endurecimento do colágeno e distúrbios renais. Açúcares se ligando ao DNA poderiam causar malformações celulares e, consequentemente, câncer.

Dentre as teorias genéticas, destaca-se a recente teoria do envelhecimento baseada na telomerase, que ressalta, por exemplo, o papel dos telômeros - sequências de ácidos nucleicos estendendo-se nas extremidades dos cromossomas que encurtam a cada divisão celular. Este encurtamento conduziria a danos celulares devido à incapacidade progressiva de a célula se duplicar corretamente, levando a disfunção celular, envelhecimento e morte. A enzima telomerase parece ter a capacidade de reparar e substituir os telômeros ajudando a regular o relógio que controla o período de vida vinculado às divisões celulares (Antiaging-Systems.com, 2010).

Há enunciados biológicos a respeito da longevidade humana, do envelhecimento, das doenças associadas ao envelhecimento e da morte cuja teoria se baseia na centralidade teleológica da ideia de maturação sexual com fins reprodutivos. Assim, sob esta perspectiva, 
as mudanças etárias resultam do aumento da taxa de desordem biomolecular que, após a maturação sexual, ultrapassam a capacidade de renovação e reparação. Isso consiste em eventos estocásticos ou aleatórios ordenados pela entropia, quando não há obstáculos a ela. Os obstáculos são constituídos pela força relativa das ligações químicas, cuja manutenção até a maturação reprodutiva é necessária para a sobrevivência da espécie.

Os genes não causam envelhecimento, mas indiretamente governam a longevidade ao determinarem o status da energia das biomoléculas antes que as mudanças etárias ocorram, ou para a maturação reprodutiva. A longevidade é indiretamente governada pelos genes em função da suposta estratégia de produzir capacidade fisiológica em excesso para melhor assegurar a sobrevivência para a maturação reprodutiva.

Dos quatro aspectos da finitude da vida, o único aspecto operado pelos humanos é a doença ou patologia, e isso apresenta um importante limite, pois, hipoteticamente, caso resolvêssemos essa dimensão, a expectativa de vida média ao nascer não ultrapassaria os 93 anos. A única forma de superar esse número aconteceria se fosse possível intervir no processo de senescência em si ou nos determinantes de longevidade.

O que parece importar, sob esta perspectiva, seria determinar as alterações nas biomoléculas que levam às manifestações do envelhecimento em outros níveis de complexidade, aumentando a vulnerabilidade a todas as doenças associadas a ele (Hayflick, 2008).

Em uma revisão de 2004, Browner et al. (2004) consideram que a longevidade humana é parcialmente herdada e que as síndromes de aceleração do envelhecimento (progeroides) que afetam a regulação da reparação do DNA, estrutura e função nuclear têm causas genéticas. Ademais, há homólogos humanos para os muitos genes que afetam o tempo de vida em modelos animais Nos seres humanos, os genes da longevidade podem desacelerar a taxa de mudanças 
vinculadas ao envelhecimento em células, aumentar a resistência a estresses ambientais, como infecção e outros agravos, e reduzir o risco de muitas condições relacionadas ao envelhecimento.

Mais recentemente, o grupo do professor Thomas Perls - o mesmo do calculador da expectativa de vida "vivendo até os 100 " - realizou uma análise genética de 1.055 idosos entre 95 e 119 anos em Boston, fazendo a comparação dos genes encontrados neste grupo com os genes de filhos de pessoas que morreram com menos de 73 anos. Os resultados mostraram que os centenários apresentam cerca de 150 polimorfismos nucleotídicos únicos (single nucleotide polymorphisms), que seriam responsáveis pela longevidade excepcional; há 19 "clusters", caracterizados por diferentes genótipos de SNP (assinaturas genéticas), que parecem anular a ação de genes responsáveis por doenças. Segundo os autores, infelizmente, isso não significa que quem não tenha esse perfil genético possa se descuidar...

Em suma, considerando as precariedades de uma busca simplória, sem qualquer ambição de revisão bibliográfica, há indícios de que o campo de hipóteses de pesquisa é bastante complexo, e não há lugar nem para conclusões categóricas nem para garantias alvissareiras de retorno para as apostas futurológicas. A redução do otimismo relativo às expectativas quanto à decodificação do DNA para ampliar o alcance dos conhecimentos genômicos acerca da saúde em geral e da longevidade em particular na virada do milênio parece ter deixado suas marcas.

\section{O olhar biopolítico}

Como tratar analiticamente a constelação díspar de elementos descritos anteriormente? Um dos encaminhamentos aqui sugeridos é partir das consagradas contribuições acerca do conceito de "biopolítica", tal como é conhecido, provenientes de Foucault (1979). Ele foi introduzido na acepção crítica atual em 1974, numa conferência no Instituto de Medicina Social da Universidade Estadual de Rio de 
Janeiro, publicada em 1979, sobre as origens da medicina social. ${ }^{4}$ Foucault elabora uma importante transição nas estratégias de poder, que passam a operar no âmbito biológico (biopoder), de tal modo que as dimensões de controle social da sociedade capitalista sobre as pessoas não atuam meramente no registro da consciência ou da ideologia, mas incidem diretamente no âmbito somático, corporal, biológico.

Ainda vale salientar que biopoder e biopolítica estão vinculados à ideia de governamentalidade. Com esta designação, Foucault compreende: a) o conjunto de instituições, processos, análises, cálculos e táticas que permitem exercer o poder sobre a população, expressos pela economia e que se produzem pelas técnicas de segurança; b) a inclinação que leva à predominância deste tipo de poder e, juntamente com ele, à sobredeterminação de técnicas de poder e de saber; c) o processo que leva do estado jurídico e administrativo ao estado de controle da população e de segurança.

No volume 1 da História da sexualidade, Foucault (1977) considera a transição da ordem disciplinar de corpos individualizados no séc. XVIII (soberania) para o controle do conjunto dos indivíduos como "população" no século XIX (biopolítica da população). Dessa forma, o liberalismo dessa época, fundamental para o desenvolvimento do capitalismo, gera uma metamorfose do poder, que se torna biopoder e se modaliza especificadamente em termos de, por exemplo, planejamento e gestão de saúde, enfocando higiene, alimentação, controle de natalidade, regulação da sexualidade.

Segundo Negri (2008), a biopolítica se institui sobre pressupostos que produzem as tecnologias do capitalismo e da soberania. Esses pressupostos vão se transformando ao longo do tempo, desenvolvendo-se, primeiramente, de forma disciplinar e depois juntando à biopolítica os dispositivos de controle. Se a disciplina se dava como uma "anátomo-política" dos corpos aplicada sobretudo aos indivíduos, a biopolítica se coloca como uma espécie de grande 
"medicina social", que se aplica ao controle das populações com a finalidade de governar a vida.

Nikolas Rose (2007) entende pela expressão "biopolítica" o feixe de estratégias específicas que envolvem questões relativas aos modos como a vitalidade humana, a morbidade e a mortalidade devem ser tratadas quanto ao nível desejável e à forma das intervenções, sobre o estabelecimento de autoridades e das intervenções que são definidas e legitimadas como as mais eficazes, e, portanto, melhores,

Para Rose (2007), hoje, a biopolítica também se relaciona ao labor de laboratórios biotecnológicos na criação de novos fenômenos (e patologias), ao poder computacional dos dispositivos que vinculam histórias clínicas com sequências genômicas, aos poderes mercadológicos das empresas farmacêuticas, às estratégias regulatórias de comitês de pesquisa, de bioética e de vigilância de drogas e alimentos e, também, à busca de lucros envolvendo todas essas instâncias.

Já o biopoder deve ser encarado mais como uma perspectiva que um conceito, no sentido de se constituir como um espectro de iniciativas mais ou menos racionalizadas, desenvolvidas por autoridades no sentido intervir no âmbito da vitalidade humana - seu nascimento, desenvolvimento, adoecimento e morte.

Não seria despropositado dizer-se epidemiopoder, se considerarmos as características básicas que definem o objeto deste campo do conhecimento - saúde e vida nas populações. Mais: na atualidade, é a normatividade de base epidemiológica que rege os preceitos e recomendações que pretendem disciplinar as populações humanas no interior dos discursos de promoção da saúde centrados no comportamento saudável que, inclusive, ajuda a nos proteger das manifestações genéricas indesejadas.

Em termos esquemáticos, consumidores das sociedades modernas são condicionados com a possibilidade de obter o produto "vitalidade". Para tanto, devem se apoiar em produtos tecnológicos e em práticas de saúde sustentadas o mais possível pelo epidemiopoder, que 
produz provas científicas com a chancela de resultados oriundos de estudos empíricos considerados robustos e de revisões sistemáticas e meta-análises. Assim se encaminha a resposta para a pergunta: quem define os riscos de situações ameaçadoras, tecnologias, produtos, "estilos de vida", propensões genéticas? Mais: é bastante incerto definir neste contexto algo como "evidência" sólida, indiscutível em um mundo em que o que se sabe e o que não se sabe sobre os riscos está inevitavelmente misturado e todo o conhecimento probabilístico pode dar margem a controvérsias. (Beck, 2008)

O epidemiopoder ocupa um lugar hegemônico no confronto das definições que se autorizam para estabelecer as decisões quanto ao rumo "correto" das políticas, dos arcabouços administrativos, legais e institucionais e das ações, baseados nos padrões ditados pela expertise técnica vigente. Mais ainda, o epidemiopoder participa ativamente na geração de uma cultura científica que configura nosso pensamento e a ideia que a sociedade moderna tem a seu respeito com base em distribuições de normalidade sustentadas pela curva normal gaussiana (Beck, 2008).

Em outras palavras, o epidemiopoder consistiria em idiomas/ vocabulários e aspectos morais sustentados pelos conhecimentos produzidos pela epidemiologia como um dispositivo de técnicas e práticas de investigação cujos resultados "revelam" as condições de saúde (riscos e agravos) de grupos humanos. Isto se dá mediante procedimentos e estratégias estatísticas logicamente integradas em termos de variáveis de tempo, local e dimensões biológicas, ecológicas, psicológicas, sociológicas, demográficas, econômicas, entre outras. Pretende constituir processos cognoscíveis com suas leis e variações com vistas a instituir racionalidades, tecnologias e programas de intervenção no âmbito da governamentalidade.

Mas, a pretendida garantia de segurança proporcionada pela perspectiva de expertise técnica vinculada ao epidemiopoder, ancorada nas noções probabilísticas de risco, se fragiliza, pois se vê obrigada 
a se afastar da lógica da segurança ao assumir a possibilidade de ocorrências desastrosas no horizonte, sem possibilidade de cálculos de risco, sem a capacidade de assegurar incondicionalmente a segurança almejada (Beck, 2008). Não é possível antecipar o que não pode ser antecipado. Nem mesmo a responsabilidade das instâncias de controle em relação aos riscos globais se mantêm, como nos casos das alterações climáticas, dos acidentes industriais com grandes efeitos ecológicos, da megacrise financeira de 2008/2009.

O princípio da prevenção torna-se montagem hiperpreventiva ao englobar o princípio da precaução, mas também a dimensão da proteção. Sobretudo ao incluir as estratégias designadas pela expressão inglesa "safety", que se refere à dimensão de segurança das pessoas vinculada à integridade corporal, seja em termos de quantidade e qualidade de alimentos, água, saneamento, moradias, espaços urbanos etc.

Admitindo a pertinência da expertise técnica em determinadas situações no campo da saúde (como na erradicação da varíola e da poliomielite), não é desprezível a possibilidade de sua aliança com o dispositivo higioterapêutico. Higioterapia, como a expressão indica, é o emprego dos recursos higiênicos na cura de doenças (Houaiss, 2008: 1.532). No caso, simultaneamente higiênica - na promoção de hábitos de vida saudável, terapêutica -, ao enfrentar as doenças civilizatórias (mesmo descurando de grandes grupos populacionais que não têm acesso à assistência médica efetiva) e também utilizando a higiene como tratamento ao estimular práticas ditadas pela medicina em função de uma postura de hiperprevenção em relação aos supostos riscos à saúde (como no caso do uso de hipocolesterolemiantes).

Assim, tais indivíduos se veem compelidos a seguir instruções para adotar comportamentos saudáveis virtuosos e a consumir produtos e expedientes preventivos como fórmula para a desejada vitalidade longeva. Em outras palavras, a promoção da saúde pos- 
sui inegáveis elementos biopolíticos imunitários. O epidemiopoder alia-se ao dispositivo higioterapêutico, naturaliza as precariedades e produz um deslocamento para riscos preveníveis e patologias tratáveis. O epidemiopoder e o dispositivo higioterapêutico atuam sobre os indivíduos fazendo com que a vida se confunda com uma série de prevenções e terapêuticas. E as terapias genéticas possuem um papel preponderante aqui.

Rose (2007) enfoca dois importantes aspectos importantes para o epidemiopoder conjugado ao poder terapêutico na biopolítica atual: 1) a molecularização biologicista dos fenômenos humanos - a vida passa a ser compreendida e abordada em termos das propriedades funcionais das sequências de codificação das bases nucleotídicas e suas variantes, dos mecanismos moleculares que controlam a expressão e transcrição gênica, das conexões entre propriedades funcionais das proteínas e sua forma constitutiva, da geração de elementos intracelulares como canais iônicos, enzimas, genes transportadores, potenciais de membrana; 2) o foco central na ideia de vitalidade - algo que pode ser abordado por distintos tipos de experts, gerar múltiplos níveis de bens e serviços, ser dividida em diversos componentes que podem ser definidos, guardados, intercambiados, comercializados em termos de tempo, espaço, órgãos, espécies, conforme diferentes contextos, instituições e grandes empreendimentos bioeconômicos. A biopolítica se converte cada vez mais em bioeconomia.

\section{Em busca de conclusão}

No momento em que a vida assume a dimensão política essencial que se torna passível de gestão, administração, cálculos, regras e normas por intermédio de políticas públicas e de vigorosas ações bioeconômicas de empreendimentos privados no mercado globalizado, fica patente que os benefícios que isto traz para alguns impõem a falta de acesso destas benesses para outros, que podem, inclusive, 
desaparecer, sem trazer danos à ordem jurídica vigente, pois esta passa a admitir estados de exceção (Agamben, 2004).

Neste ponto, ainda cabe assinalar uma passagem relevante de Foucault sobre o risco genético, elaborada há cerca de três décadas, já intuindo os rumos biopolíticos sob a égide neoliberal na qual o mercado seria o núcleo de onde emanariam as decisões de manipulação genômica. Segundo ele, seria possível, com "bons equipamentos genéticos" (sic), identificar riscos, "indivíduos de risco" (sic), conforme o perfil genético dos progenitores, e com isso estabelecer quais são aqueles dotados de capacidade de produzir indivíduos protegidos da doença ou de baixo risco, tanto para si como para a sociedade. Tais equipamentos irão fazer parte dos cálculos e circuitos econômicos. Os pedigrees genéticos entram em questão na hora de se escolher cônjuges e produzir filhos dotados de bons equipamentos genéticos, ou seja, "capital humano". Para se ter acesso a essas benesses, será necessário investir economicamente para se dispor de recursos para tanto (Duarte, 2010).

Rose (2007), ao discutir a noção de suscetibilidade na atual medicina genômica, afirma que ela escapa ao modelo do normal e do patológico ao incluir um terceiro termo entre os dois: o da pré-doença, que transforma o indivíduo em um pré-paciente. Isto é, se examinada geneticamente, a pessoa apresenta sinais genômicos potenciais de risco considerável de adoecer, ocupa o lugar de não sadio, não doente. Da mesma forma, o discurso das predisposições cria a "pessoa predisposta".

Do século XIX em diante, as predisposições eram localizadas em termos de linhagem e dispostas em termos de constituição herdada. Se esta constituição é débil ou afetada de algum modo por uma vida licenciosa, imoral, dissoluta - pecaminosa sob a ótica cristã -, pode predispor a pessoa a várias doenças, como tuberculose, escrófula, sífilis, neuropatias, epilepsia, loucura, e também a vícios como o jogo, o alcoolismo. Isso pode, inclusive, ocorrer 
uterinamente, pela conduta desregrada da mãe, de modo a atingir a constituição do feto.

Esta configuração de constituição, predisposição e causa desencadeante não é nova, mas permanece, ainda que com alterações, até os dias de hoje. Maus hábitos da mãe grávida afetam o embrião tanto pelos componentes genéticos como pelos ditos comportamentais como, por exemplo, se a mãe é usuária de drogas ou mesmo tabagista. A lógica atual do controle comportamental dos riscos do "estilo de vida" à saúde apresenta pontos de conexão com a dimensão moral ligada à etiopatogenia, por sua vez vinculada à ideia de predisposição do século XIX.

Como diz Rose (2007), nos últimos 150 anos, as elaborações sobre o risco têm sido cruciais à biopolítica, e, no interior dos contextos sociopolíticos liberais avançados, as interações entre a dimensão biológica individual e a saúde e bem-estar coletivos não consiste mais em questões de classificação, identificação, restrição, eliminação de indivíduos deficientes ou de promoção eugênica de traços esperados em função da aptidão geral seja da população, da nação ou da raça, mas, sim, de estratégias biopolíticas que identificam, gerenciam e prescrevem ações preventivas e curativas para indivíduos, grupos e locais com altos níveis de risco.

De todas as formas, é evidente a dimensão de moral e bons costumes que prevalece nesse discurso, mesmo incluindo as dimensões genéticas que podem se manifestar pelas exposições não virtuosas das pessoas. Pode surgir uma atitude de missão responsável que pode chegar às raias de uma rígida postura missionária consigo mesmo. Parafraseando Rose, trata-se de assumir a posição de um fiel cidadão, epidemiologicamente ativo, que tem a tarefa de controlar sua vida segundo atos de cálculo e escolha racionais, aberto ao aconselhamento genético-epidemiológico que sustenta a promoção de saúde que nos chega pelo discurso dos muitos expertos que normatizam as questões de saúde. 
As decisões de saúde ocorrem no interior de um contexto de relações de poder pastorais - uma estratégia de poder dirigida a indivíduos e grupos de modo a atingir o bem do "rebanho" de modo inter-relacional. Isso envolve a dimensão das organizações profissionais e dos comitês de ética, resultados de pesquisa biomédica e epidemiológica, condutas de empregadores e instâncias securitárias, testagens psicológicas e genéticas, aconselhamento por parte de organizações civis especializadas em determinadas enfermidades, incluindo aportes de instâncias religiosas propriamente ditas (Rose, 2007).

Assim, deve-se estar atento a enfermidades existentes, suscetibilidades e propensões; deve-se buscar informações baseadas em evidências para que se cumpra com o ajuste do "estilo de vida" e das propensões genéticas para minimizar a doença e otimizar a saúde; deve-se conduzir a própria vida de modo estratégico e responsável em relação aos outros de modo a ponderar decisões sobre empregos, casamentos, reprodução, à luz de elementos biomédicos e epidemiológicos. A saúde pública atual parece esperar isso de cada um de nós... Difícil é aceitar estas proposições sem ao menos discutir seus pressupostos.

É preciso convocar dois artistas para trazer outra perspectiva ao afã de longevidade vigente no âmbito das práticas sanitárias dominantes, não somente aquelas de cunho genético. Um deles é o cineasta Woody Allen, que diz: "Você pode viver para chegar aos cem anos de idade se você desistir de todas as coisas que fizeram você querer viver até os cem anos" (The Quotations Page, 2010).

O outro é o compositor e cantor espanhol Joaquin Sabina. Em um disco sintomaticamente chamado Física y química, de 1992, ele gravou uma canção intitulada Pastillas para no soñar (Comprimidos para não sonhar), cuja letra (em tradução nossa do castelhano para o português), com a qual encerramos este texto, diz (Joaquín Sabina. net, 2010): 
Se o que você quer é viver 100 anos,

Não prove os licores do prazer.

Se tem alergia aos desenganos,

Esqueça essa mulher.

Compra uma máscara antigás,

Mantenha-se dentro da lei.

Se o que você quer é viver 100 anos,

Faça exercícios todos os dias.

Ponha gel no cabelo, para que não te despenteie a brisa da liberdade.

Construa um lar onde nunca reine algo mais que a segurança. Evite o fumo dos bares,

Reduza a velocidade.

Se o que você quer é viver 100 anos

Vacine-se contra o acaso,

Diga a essa mulher que não te procure mais

e se reclama o coração, na farmácia pode pedir: tem remédio para não sonhar?

Se você quer ser Matusalém, vigia teu colesterol,

Se sua meta é viver 100 anos, nunca faça sem camisinha.

E perigoso que sua pele nua roce outra pele sem estar esterilizada.

Que não se infiltre o virus da dúvida no leito conjugal.

E se em suas noites falta sal, para isso existe a televisão.

Se o que você quer é chegar aos 100 anos,

não viva como eu, deixe passar a tentação,

diga a esta mulher que não te procure mais

E se reclama o coração, na farmácia, pode pedir: tem remédio 


\section{Referências}

AGAMBEN, G. Homo sacer: o poder soberano e a vida nua. Belo Horizonte: UFMG, 2004.

BECK, U. La sociedad del riesgo mundial: en busca de la seguridad perdida. Buenos Aires: Paidós, 2008.

BOSTROM, N. Human genetic enhancements: a transhumanist perspective. Journal of Value Inquiry, 37(4): 493-506, 2003.

BROWNER, W. S. et al. The genetics of human longevity. American Journal of Medicine,117(11): 851-860, 2004.

DAWKINS, R. The selfish gene. Oxford: Oxford University Press, 1976.

DUARTE, A. Sobre a biopolítica: de Foucault ao século XXI. Revista Cinética. Disponível em: <http://www.revistacinetica.com.br/cep/andre_duarte.pdf>. Acesso em: 07 set. 2010.

ESTANQUEIRO-ROCHA, A. S. Biopolítica. Disponível em: <http://www. scribd.com/doc/7392949/Biopolitica>. Acesso em: 7 ago. 2010.

FOUCAULT, M. História da sexualidade: a vontade de saber. Rio de Janeiro: Graal, 1977. v. 1.

FOUCAULT, M. O nascimento da medicina social. In: FOUCAULT, M. Microfisica do poder. Rio de Janeiro: Graal, 1979.

HAYFLICK, L. The biology of human longevity, aging and age-associated diseases. In: BEYOND SYMPOSIUM ORLANDO, Orlando, 7-9 jan. 2008. Disponível em: <http://www.soa.org/library/monographs/retirement-systems/ living-to-100-and-beyond/2008/january/mono-li08-03-hayflick-abstract.pdf>. Acesso em: 01 set. 2010.

HOUAISS, A. Dicionário Houaiss da língua brasileira. Rio de Janeiro: Objetiva, 2001.

JABLONKA, E. \& LAMB, M. J. Evolution in four dimensions: genetic, epigenetic, behavioral, and symbolic variation in the history of life: Cambridge: MIT Press, 2005.

NEGRI, A. La fabrica de porcelana: una nueva gramática de la política. Buenos Aires: Paidós, 2008.

ROSE, N. The politics of life itself: biomedicine, power and subjectivity in the twenty-first century. Princeton: Princeton University Press, 2007. 
SEBASTIANI, P. et al. Genetic signatures of exceptional longevity in humans. Science, 2010. Disponível em: <http://www.sciencemag.org/cgi/rapidpdf/ science.1190532v1.pdf>. Acesso em: 02 set. 2010.

\section{Internet:}

ANTIAGING-SYSTEMS.COM. Site. Disponível em: <http://www.antiaging-systems.com/ARTICLE-613/theories-of-aging.htm>. Acesso em: 31 ago. 2010. JOAQUÍN SABINA.NET. Site. Disponível em: <http://www.joaquinsabina. net/2005/11/06/pastillas-para-no-sonar>. Acesso em: 07 set. 2010.

LIVING TO 100. Site. Disponível em: <http:/calculator.livingto100.com/ calculator>. Acesso em: 30 ago. 2010.

NAVIGENICS. Site. Disponível em: <http://www.navigenics.com>. Acesso em: 30 ago. 2010.

PORTAL FIGHT AGING. Site. Disponível em: $<$ http://www.longevitymeme. org/about_definitions.cfm>. Acesso em: 30 ago. 2010a.

. Site. Disponível em: $<\mathrm{http}: / / \mathrm{www}$. longevitymeme.org/start_on_healthy_life_extension.cfm>. Acesso em: 30 ago. 2010b.

. Site. Disponível em: <http://www.longevitymeme.org/about.cfm>. Acesso em: 30 ago. 2010c.

. Site. Disponível em: <http://www.longevitymeme.org/articles/viewarticle.cfm?article_id=3>. Acesso em: 30 ago. 2010 d.

. Site. Disponível em: <www.longevitymeme.org>. Acesso em: 27 out. 2011.

PORTAL METHUSELAH FOUNDATION. Site. Disponível em: $<$ http://www. mfoundation.org/?pn=mj_donations_the300>. Acesso em: 30 ago. 2010. PORTAL WIRED. Site. Disponível em: $<$ http://scienceblogs.com/geneticfuture/2010/02/the_end_for_the_decodeme_perso.php>. Acesso em: 30 ago. 2010. THE QUOTATIONS PAGE. Site. Disponível em: <http://www.quotationspage. com/quote/27633.html>. Acesso em: 03 set. 2010. 
PARTE II

REPRODUÇÃO, MOLECULARIZAÇÃO E BIOPOLÍTICA DA VIDA EM SI 


\title{
DOAÇÃO DE SÊMEN E CLASSIFICAÇÃO ÉTNICO-RACIAL NO BRASIL
}

\author{
Rosely Gomes Costa
}

\section{Introdução}

No Brasil ainda não foram aprovadas leis relativas à reprodução assistida. Há alguns projetos de lei que estão tramitando no Congresso Nacional e serão mencionados mais adiante. Por esse motivo, as clínicas, hospitais e bancos de sêmen que trabalham com reprodução assistida seguem a resolução 1.358/92, do Conselho Federal de Medicina, de 30 de setembro de 1992. Em relação à doação de sêmen, objeto deste texto, a resolução reza que a doação de gametas deve ser anônima, ou seja, o doador não deve conhecer o casal ao qual o sêmen for doado, nem as possíveis crianças geradas, assim como estas e o casal não terão acesso à identidade do doador. Assim, uma vez que o casal receptor não pode ter acesso à identidade do doador, os bancos de sêmen e a equipe médica envolvida passam a ser intermediários nesse processo.

O que este capítulo pretende mostrar é que na prática isso significa um desrespeito aos princípios éticos de autonomia, privacidade e igualdade. Também pretende enfatizar o problema levantado pela questão racial. Em um país como o Brasil, com uma classificação racial tão flexível, que caminha lado a lado com posturas racistas, a intermediação feita pelos bancos de sêmen e pelas equipes médicas passam pelos critérios de classificação racial próprios de cada um 1 Texto publicado anteriormente em Physis - Revista de Saúde Coletiva, 14(2): 235-255,
2004 (reproduzido com permissão). 
deles, que nem sempre são os mesmos dos doadores e receptores de sêmen.

\section{Metodologia}

Este texto foi extraído de uma pesquisa maior, realizada no Brasil e na Catalunha (Espanha), que visava o tema da reprodução entrelaçando questões relativas a racialização, etnia, identidade coletiva e tecnologias reprodutivas. A intenção era pesquisar quais características físicas e morais as pessoas que procuram reprodução assistida $^{2}$ desejam ver reproduzidas em seus filhos e como, e em que medida, estas características apontam para noções referentes a raça, etnia e identidade coletiva. Objetivava-se entrevistar pessoas que utilizassem as técnicas de doação de gametas (óvulos e esperma) e barriga de aluguel porque estas envolvem a participação e a seleção de uma terceira pessoa no processo reprodutivo. Tais tecnologias estariam ou não sendo usadas para afirmar ou negar características tidas como raciais/étnicas/coletivas? A proposta era entrevistar clientes/ pacientes e médicos de clínicas públicas e privadas de reprodução assistida nas cidades de Campinas (São Paulo, Brasil) e Barcelona (Catalunha, Espanha), de bancos de sêmen da cidade de São Paulo (Brasil) e Barcelona, para realizar uma pesquisa comparativa. ${ }^{3}$

Os dados apresentados a seguir referem-se a dois bancos de sêmen que fizeram parte de meu estudo, situados na cidade de São Paulo (Brasil). Eram os dois únicos bancos de sêmen existentes no Estado de São Paulo na época da pesquisa, e forneciam sêmen para

2 Os termos "reprodução assistida" e "tecnologias reprodutivas" dizem respeito aos procedimentos relativos à inseminação artificial, fertilização in vitro, congelamento de sêmen e embriões, doação de material reprodutivo, seleção sexual e diagnóstico pré-implantatório, pesquisas com células e embriões humanos e clonagem (embora esta última não tenha sido colocada em disponibilidade no mercado de serviços médicos) (ver Corrêa \& Loyola, 1999).

3 O Relatório Final referente a essa pesquisa, intitulado Concebendo filhos, concebendo idéias: reprodução assistida, raça, etnia e identidades coletivas, foi enviado à Fundação de Amparo à Pesquisa do Estado de São Paulo (Fapesp), financiadora da investigação que resultou em meu pós-doutorado em Antropologia. 
a capital, para todo o interior do estado e também para cidades de outros estados do país que não possuíam banco de sêmen.

Foram entrevistadas as médicas responsáveis por esses bancos de sêmen, sendo indagadas sobre os critérios dos bancos, seu funcionamento etc.

\section{A questão racial no Brasil}

Procurarei resumir uma discussão muito extensa realizada pela academia e pelos movimentos sociais relativa à classificação racial no Brasil.

Nos anos de 1950, comparando a sociedade brasileira com a norte-americana, Oracy Nogueira (1955b) já enfatizava que no Brasil prevalece o preconceito de marca, enquanto em países como os Estados Unidos prevalece o preconceito de origem. Isto é, no Brasil prevaleceria o preconceito de raça exercido em relação à aparência, quando se toma por pretexto para as suas manifestações os traços físicos do indivíduo, a fisionomia, os gestos, o sotaque, enquanto nos Estados Unidos prevaleceria um preconceito racial de origem, quando basta a suposição de que o indivíduo descende de certo grupo étnico para que ele sofra as consequências do preconceito.

Este tipo de preconceito de marca dá origem a uma flexibilidade muito grande na classificação racial, que passa a depender de outros fatores. Em um texto de 1954, escrevia Oracy Nogueira em relação ao Brasil:

Os limites entre as diversas categorias - brancos, mulatos claros, mulatos escuros, pretos - são indefinidos, possibilitando casos de aparecimento de identificação controversa, podendo, além disso, a identificação de um indivíduo quanto à cor ser influenciada pela associação com outras características de status, como o grau de instrução, a ocupação e hábitos pessoais, com tendência a se atenuar a cor de indivíduos socialmente bem-sucedidos. De outro lado, a maleabilidade de critérios, juntamente com a resis- 
tência à identificação da própria cor como escura, faz com que o limiar entre o branco e o não branco varie com a cor do próprio observador [...]. (Nogueira, 1955a: 460)

No Brasil atual ainda prevalece uma lógica segundo a qual o outro racial e culturalmente marcado é o não branco, contraposto a uma brancura normativa e dominante. As várias vertentes do movimento negro enfatizam a importância de se trabalhar com a autoestima negra, com os valores e a estética que consideram próprios dos negros, com o intuito de romper com a lógica da dominação da valorização do mundo branco.

Há muitas discussões, dentro e fora da academia, sobre qual seria a melhor forma de se combater a discriminação racial. Uma das principais questões colocadas em relação ao tema refere-se à pertinência ou não de se realçar ${ }^{4}$ as diferenças denominadas raciais na construção de uma identidade negra para o combate da discriminação racial.

Por um lado, considera-se que o realce propicia a consciência da raça, conduz às políticas de ação afirmativa, ao reconhecimento e respeito das diferenças. Essa é a postura de grande parte dos movimentos negros no Brasil e de autores como Rosa-Ribeiro (2000), que considera que o racismo brasileiro se caracteriza por sua pretensão universalista e inclusiva, que acaba por ignorar ou negar as diferenças (mito da democracia racial), tornando os negros e seus problemas (preconceitos, desigualdades) invisíveis. Esta pretensão universalista estaria atrelada à formação do Estado moderno, que tende a apresentar uma visão inclusiva que tudo abarca, obscurecendo as exclusões.

De maneira oposta, considera-se que o realce conduz a uma segregação racial e a uma explicitação do conflito racial. Ainda nesta última posição, considera-se que o realce da noção de raça conduz ao cerceamento da possibilidade de que as diferenças possam se

4 Utilizo o termo "realçar" como proposto por Barth (1969) no estudo de grupos étnicos. 
manifestar de maneiras as mais variadas e ao cerceamento da liberdade de escolha e diferenciação, que repousa no indivíduo e não em grupos fechados (Appiah, 1997).

É nesse debate que se insere a discussão a respeito da pertinência ou não da introdução, no país, de políticas de ação afirmativa para a população negra. Em relação a essa pertinência, várias posições podem ser encontradas, ${ }^{5}$ mas não é o caso de serem discutidas aqui.

No desenvolvimento de minhas pesquisas e reflexões, considerei que "raça" é uma noção em que características fenotípicas como cor da pele, tipo de cabelo, formato do nariz, espessura dos lábios, entre outros são utilizadas como parâmetros para classificação. Porém, tais características só possuem significado no interior de uma ideologia preexistente, de uma ideologia que cria os fatos ao relacioná-los uns aos outros. Apenas por causa e dentro dessa relação estabelecida é que tais características funcionam como critérios e marcas de classificação (Guimarães, 1995). Assim, as marcas importam justamente na medida em que representam diferenças em relação a outras pessoas, diferenças que se traduzem, sobretudo, em desigualdades sociais (Appiah, 1997). A noção de raça aponta para a crença de que os corpos são espaços privilegiados de inscrições e sentidos (Kofes, 1996; Piscitelli, 1996), e por isso seu estudo é fundamental.

No Brasil encontramos situações tanto de uma identidade racial negra positiva, compartilhada por brancos e não brancos, como a de uma identidade racial negra negativa, compartilhada por brancos e não brancos. Enquanto a primeira certamente é fruto da mobilização da população negra em movimentos sociais que lutam por justiça, equidade, elevação da autoestima, valorização e respeito, a segunda parece advir da qualificação da brancura como norma e valor.

A discussão sobre relações raciais vem apontando que, no Bra-

5 Estas posições se referem àquelas apresentadas em um seminário promovido pelo Governo Federal em 1996, em Brasília, que reuniu intelectuais brasileiros e brasilianistas para debater sobre a viabilidade da introdução no país de um modelo de engenharia social baseado nas chamadas "políticas de ação afirmativa" norte-americanas (ver Grin, 2001). 
sil, mais que uma definição fenotípica ou de origem, as definições de cor e de "raça" dependem do lugar social ocupado em relação a contextos específicos referidos a classe, gênero, prestígio, proximidade/intimidade, e relativos a quem pergunta e a quem responde. A cor é um atributo a ser negociado nos diversos contextos e relações que se estabelecem entre pessoas, entidades, movimentos sociais, programas políticos etc. (Maggie, 1991).

Dessa forma, a categorização dos bancos de sêmen e das equipes médicas sobre cor e "raça" estão também informadas pela relação que se estabelece entre o médico que entrevista e o candidato a doador; entre a posição de status/poder do médico e a do candidato a doador, estabelecida pela sua idade, escolaridade, profissão etc.

Assim, a classificação de cor e "raça" dos bancos de sêmen já é um filtro realizado pelas instituições médicas que define quem é e $O$ que é ser branco, negro, mulato, mulato claro, mulato escuro, ter a pele branca clara ou média etc.

\section{Os bancos de sêmen}

A escolha do doador por parte do médico/equipe médica tem como critério a semelhança imunológica (avaliada pela tipagem sanguínea) e fenotípica entre doadores e receptores, independentemente do desejo expresso por cada casal em particular em relação a essa semelhança. Assim, ainda que houvesse um desejo de branquear ou enegrecer através do uso desse tipo de tecnologia, esse desejo seria barrado pelas instituições médicas, que tomam para si a responsabilidade de garantir que a reprodução seja feita entre "semelhantes".

Um dos bancos de sêmen estudados (banco n. 1) afirma, em relação à escolha do doador: "Para que o futuro bebê seja parecido com o 'pai', o sêmen é selecionado de um doador semelhante ao mesmo, inclusive com grupo sanguíneo compatível". Assim, é oferecida ao casal uma lista de possíveis doadores que sejam "parecidos com o "pai" e que tenham o mesmo tipo sanguíneo. Nessa lista, devido 
ao sigilo, não consta o nome do doador, mas são encontrados os seguintes itens: número do doador, tipo de sangue, $\mathrm{Rh}$, raça, origem étnica, religião, cor da pele, cor e textura dos cabelos, cor dos olhos, altura, peso, constituição óssea, ocupação e hobby.

Segundo a médica responsável pelo banco, não há informação sobre a idade nem sobre o estado civil do doador porque isso não importa para o casal receptor; o que importa são as características físicas hereditárias. Sendo assim, perguntei por que há informação sobre religião, hobby e ocupação do doador se estas não são características físicas hereditárias, e a resposta foi de que, na dúvida entre dois ou três doadores, o casal escolhe aquele com o qual se identifica mais. Por exemplo: se o doador veleja ${ }^{6}$ e o receptor também, cria-se uma identificação entre eles. Portanto, enquanto idade e estado civil não aparecem associados à hereditariedade (o que parece óbvio), religião, ocupação e hobby - que dizem respeito aos gostos e às inclinações pessoais - aparecem a ela associados, e procura-se, nestes casos, toda identificação possível entre doador e receptor.

A coleta dessas informações se realiza da seguinte maneira: os itens "tipo de sangue" e "Rh" são anotados do resultado do exame de sangue; os itens "religião", "altura", "peso", "ocupação" e "hobby" são perguntados ao doador. Sobre o item "origem étnica", pergunta-se ao doador de onde são seus pais. Os itens "cor da pele", "cor dos olhos", "cor e textura do cabelo", "constituição óssea" e "raça" são observados e anotados pela equipe médica do banco de sêmen. Perguntei à médica se não surgiam dúvidas quanto à anotação dos itens "raça" e "cor da pele", e ela me respondeu que, pela fisionomia, dá para ver se a origem étnica é árabe, mesmo se a raça é caucasiana. Disse que, se vê que é mulato, nem pergunta, já anota "mulato". Ela olha, por exemplo, se a pessoa tem "fisionomia negroide" verificando

6 É interessante atentar para o exemplo oferecido pela médica, já que, no Brasil, velejar é
um esporte de elite. 
o nariz, se é moreno mais escuro. Considera que não dá para dizer direito o que ela olha, que só olhando mesmo para saber.

Assim, raça, cor da pele, cor dos olhos, cor e textura dos cabelos e constituição óssea são consideradas como dados óbvios que podem ser anotados diretamente pela equipe médica e não precisam ser perguntados ao doador. Diferentemente da origem étnica, religião, altura, peso, ocupação e hobby, que precisam ser perguntados. ${ }^{7} \mathrm{De}$ qualquer maneira, todas essas características aparecem como podendo ser transmitidas hereditariamente (inclusive, em alguma medida, a religião, o hobby e a ocupação) e por isso fazem parte das informações sobre o doador.

As categorias possíveis para a informação sobre raça são: caucasiana, negra, oriental, hispânica (doadores oriundos de outros países da América Latina) e índia. Para cor da pele, são: a) se doador caucasiano: branca ou morena; b) se negro: negra ou mulata; c) se oriental: branca ou morena. ${ }^{8}$

Segundo a médica, o casal quer sempre que o doador seja parecido com o marido/companheiro. Mas já houve uns três ou quatro casos em que a pessoa dizia que, apesar de ser morena, a irmã era loira de olho azul, e queria um doador mais claro. Não houve nenhum caso em que se desejava um doador mais escuro. Apesar de ser o casal a escolher o doador, a médica já fornece a ele uma lista pré-selecionada de doadores considerados pelo banco de sêmen como parecidos com o receptor.

No outro banco de sêmen estudado (banco n. 2), o candidato a doador passa por uma entrevista com o médico e preenche uma ficha. Nesta ficha constam: tipo sanguíneo; estado civil; número de filhos (se tiver); local de nascimento; religião; país de origem dos pais, dos avós paternos e maternos; altura; peso; escolaridade; profissão;

7 A origem étnica é perguntada ainda que a médica considere que "pela fisionomia dá pra ver se a origem étnica é árabe, mesmo se a raça é caucasiana".

8 Segundo a médica, "Tem oriental que toma sol e fica preto". 
hobbies, além de perguntas sobre a saúde do candidato. Constam ainda, da ficha, os itens:

- raça, que deve ser selecionada entre as opções: branca, negra, amarela, indígena e parda;

- cor do cabelo, que deve ser selecionada entre as opções: preto, ruivo, loiro, loiro médio, castanho, castanho-escuro, castanho-claro e castanho-avermelhado;

- textura do cabelo, que deve ser selecionada entre as opções: liso, crespo, ondulado, calvo e careca;

- cor dos olhos, que deve ser selecionada entre as opções: pretos, azuis, verdes, violetas, castanhos e castanhos-claros;

- cor da pele, que deve ser selecionada entre as opções: branca clara, branca média, morena, mulata, oliva e negra;

- constituição óssea, que deve ser selecionada entre as opções: grande, média e pequena.

Diferentemente do banco de sêmen n. 1, aqui é o próprio candidato a doador quem preenche a ficha; porém, a médica responsável pelo banco ressaltou que, se o médico achar que o candidato está preenchendo algum dado de forma incorreta, ele o corrige.

Também diferentemente do banco de sêmen $\mathrm{n}$. 1, aqui é a equipe médica do banco que seleciona os doadores com características semelhantes aos receptores, abalizadas pela compatibilidade imunológica e por semelhanças fenotípicas entre ambos. Alguns médicos oferecem cinco ou seis possíveis doadores para que o casal receptor faça a escolha, enquanto outros já chegam para o casal com um doador previamente selecionado como o mais apropriado, mais parecido com o receptor ou, às vezes, parecido com o casal. Pois, segundo a médica, são as características do casal que são avaliadas.

As características do casal receptor são coletadas pelo médico, que preenche uma ficha que contém os seguintes dados: tipo sanguíneo, raça, origem étnica, religião, altura, peso, cor e textura dos cabelos, cor dos olhos, cor da pele, constituição óssea, seguindo a 
mesma seleção de opções dos doadores apresentada acima. Após comparação entre as fichas, o médico seleciona o doador que julga adequado.

Segundo a médica responsável, o banco tem sêmen de todas as raças, mas o mais procurado é o do doador branco de cabelo liso, escuro, porque esse é o biótipo do brasileiro. Sêmen de doadores negros e amarelos tem pouca procura.

A médica afirmou que nunca nenhum casal escolheu um doador de sêmen que fosse diferente fisicamente do receptor; todos desejam doadores parecidos consigo próprios.

No hospital público estudado, é o casal que compra o sêmen, sem interferência da clínica. Porém, a compra é feita no banco de sêmen n. 2, que fornece para a escolha do casal uma lista de possíveis doadores selecionados previamente pelo próprio banco, segundo sua semelhança imunológica e fenotípica com o casal receptor. Somente nos casos das clínicas privadas estudadas que recorrem ao banco de sêmen n. 1 o casal pode escolher o doador que deseja. Mas, ainda nesses casos, as instituições médicas atuam novamente como mediadoras e reguladoras das relações referentes ao processo reprodutivo.

\section{Discussão}

Este segundo nível de regulação das instituições médicas citado acima se refere ao fato de que, nos bancos de sêmen pesquisados, são os médicos/equipes médicas os responsáveis por categorizar os doadores segundo seus próprios critérios. Assim, toda discussão existente dentro e fora da academia sobre classificação racial no Brasil parece passar ao largo das instituições médicas que classificam os candidatos a doadores, que vão aos bancos de sêmen sem grandes problemas. O banco tem sêmen de todas as raças, mas o mais procurado é o do doador branco de cabelo liso, escuro, porque esse é o biótipo do brasileiro. 
$\mathrm{Na}$ classificação realizada pelos bancos de sêmen, há que se considerar que é a população do próprio banco que serve como paradigma para a elaboração dos critérios de classificação, isto é, os doadores e receptores de esperma. Nos dois bancos, segundo as médicas, a maioria dos doadores é composta por "caucasianos", e o sêmen mais procurado é o do doador "branco". Os doadores "negros" são poucos porque há pouca procura por seu sêmen.

Portanto, é a partir da generalização da população do banco que uma das médicas caracteriza como "biótipo do brasileiro" o "branco de cabelo escuro e liso", visto ser esse o tipo de sêmen mais procurado no banco. Neste caso, não se considerou o custo elevado de cada dose inseminante, que restringe $o$ acesso ao banco da parcela da população mais desfavorecida economicamente. Ao contrário dela, a médica do outro banco considerou que o sêmen de doador "negro" é menos requisitado porque as pessoas "negras" têm um nível socioeconômico mais baixo, não tendo, portanto, acesso à compra de sêmen por causa de seu alto custo.

Nesse sentido, torna-se perfeitamente justa a afirmação da médica do banco de sêmen, em relação à "raça" do doador, de que só olhando mesmo para saber. Pois essa afirmação aponta justamente para a necessidade de estabelecimento de uma relação para realizar a classificação.

Dessa forma, a categorização das instituições médicas sobre cor e "raça" estão também informadas pela relação que se estabelece entre o médico que entrevista o candidato a doador e o candidato; entre a posição de status/poder do médico e a do candidato a doador, estabelecida pela sua idade, escolaridade, profissão etc.

Assim, a classificação de cor e "raça" dos bancos de sêmen já é um filtro realizado pelas instituições médicas que define quem é e $o$ que é ser branco, negro, mulato, mulato claro, mulato escuro; ter a pele branca clara ou média etc.

Quando é o médico/equipe médica que realiza a escolha do doador, o que se observa é que institucionalmente já está prescrita 
a necessidade de semelhança tanto imunológica quanto fenotípica entre doadores e receptores. Ainda que o critério de semelhança imunológica se justifique por uma necessidade estritamente médica e o critério de semelhança fenotípica vise evitar problemas familiares, há que se considerar que a não mistura de "raças", a impossibilidade de branqueamento ou enegrecimento, já se encontra prescrita e controlada pelas instituições médicas, independentemente do desejo dos casais.

$O$ fato de o médico corrigir (em um dos bancos de sêmen) a informação dada pelo doador em relação às suas características físicas aparece como garantindo a uniformidade de critérios por parte do banco, e garantindo, também, que os doadores não "passem pelo que não são", isto é, "não enganem ou não passem adiante o engano em que se encontram" sobre suas próprias características. Esse tipo de "engano" pode dizer respeito tanto a se fazer "passar por branco" como a "querer afirmar-se como negro". O primeiro caso relaciona-se ao ideal de branqueamento que leva a autodeclarações que tendem a "atenuar" a cor, enquanto o segundo associa-se com a reivindicação política da identidade negra, que leva a autodeclarações que tendem a acentuar a cor.

Esse controle exercido pelo banco de sêmen em relação à declaração sobre a cor/raça parece inserir-se em um panorama geral de vigilância sobre classificação racial no Brasil.

O projeto de lei que se encontra em estágio mais avançado de tramitação é o 1.184/2003, de autoria do Senado Federal (Diniz, 2003). A ele foram apensados outros três projetos de lei: o 2.855/1997, de autoria do deputado Confúcio Moura (PMDB/RO), o 120/2003, do deputado Roberto Pessoa (PFL/CE), e o 2.061/2003, da deputada Maninha (PT/DF). Estar apensado significa que a tramitação legislativa será realizada em conjunto e que qualquer discussão sobre o projeto do Senado será feita junto com a dos demais.

Todos os projetos convergem para a autorização da doação de gametas, mas divergem quanto à manutenção do sigilo da identidade 
do doador. Enquanto o primeiro e o terceiro projeto preveem a possibilidade de quebra do sigilo da identidade do doador, o segundo considera apenas a filiação social e o quarto sugere ainda o não reconhecimento da identidade biológica. No caso da possibilidade da quebra de sigilo, o argumento reside no direito dos nascidos de conhecer a identidade dos pais biológicos e na importância desse conhecimento na constituição da identidade da criança, ainda que tal quebra não implique direitos sucessórios. No caso da manutenção do anonimato, o argumento baseia-se no direito de privacidade e sigilo de doadores e receptores.

Todos os projetos preveem, ainda, que a escolha do doador é de responsabilidade do serviço médico, que deverá buscar a maior semelhança possível entre as características fenotípicas e imunológicas de doadores com receptores.

As propostas dos projetos de lei, ao alocarem no serviço médico a responsabilidade pela escolha do doador, reforçam o poder das instituições médicas de controlar e classificar a cor e a raça dos doadores e receptores.

\section{Conclusão}

Assim, os serviços médicos tornam-se responsáveis por decisões que não são (ou não deveriam ser) de sua alçada, como é o caso de decidir sobre a classificação racial de doadores e receptores e de decidir e garantir que não sejam introduzidas na descendência características físicas ou genéticas estranhas aos cônjuges.

Dessa forma, pelo menos três dos princípios éticos básicos de autonomia, privacidade, justiça, igualdade e qualidade são desrespeitados: o da autonomia, o da privacidade e o da igualdade. $\mathrm{O}$ da autonomia porque a decisão sobre a escolha do doador de sêmen não é do casal receptor e sim das equipes médicas, assim como a decisão sobre a classificação racial dos casais receptores e do doador do sêmen que será recebido também não é do casal nem do doador. O da privacidade porque as equipes médicas buscam garantir que não sejam 
introduzidas na descendência dos casais receptores características físicas ou genéticas estranhas aos cônjuges, queiram eles ou não. E de igualdade porque os bancos de sêmen e as equipes médicas retêm o poder de realizar a classificação racial de doadores e receptores de sêmen segundo seus próprios critérios, desconsiderando os critérios dos casais receptores e dos doadores de sêmen.

Portanto, buscando evitar futuros problemas para doadores e receptores, tanto a resolução do Conselho Federal de Medicina quanto as propostas dos projetos de lei que recomendam que a doação de sêmen seja anônima acabam por engendrar problemas de ordem ética.

Esta questão não é de fácil resolução por vários motivos. $\mathrm{O}$ primeiro deles é que as opiniões divergem em relação a como proceder em relação à classificação racial no Brasil. O segundo é que o anonimato na doação exige que as instituições médicas sirvam de intermediárias entre doadores e receptores. Porém, a ausência de anonimato leva a outros problemas que não cabem ser discutidos aqui. ${ }^{9}$ O terceiro é que respeitar a autoclassificação de doadores e receptores também pode gerar problemas referentes ao desejo de compatibilidade fenotípica do receptor em relação ao doador.

Ainda que seja um problema de difícil resolução (ou por isso mesmo), ele deve ser apontado e levado em consideração nas discussões sobre ética na saúde reprodutiva.

\section{Referências}

APPIAH, K. A. Na casa de meu pai: a África na filosofia da cultura. Rio de Janeiro: Contraponto, 1997.

BARTH, F. (org.). Ethnic groups and boundaries. London, Oslo: George Allen \& Unwin, Universitets Forlaget, 1969.

CORREA, M. \& LOYOLA, M. A. Novas tecnologias reprodutivas: novas estratégias de reprodução? Physis - Revista de Saúde Coletiva, 9(1): 209-234, 1999. DINIZ, D. Tecnologias reprodutivas conceptivas: o estado da arte do debate

9 Para uma discussão a esse respeito, consultar Salem (1995). 
legislativo. Jornal Brasileiro de Reprodução Assistida, 7(3): 10-19, 2003.

GRIN, M. Políticas de ação afirmativa e ajustes normativos: o Seminário de Brasília. Novos Estudos Cebrap, 59: 172-192, 2001.

GUIMARÃES, A. S. A. Racismo e anti-racismo no Brasil. Novos Estudos Cebrap, 43: 26-44, 1995.

KOFES, S. Apresentação. Cadernos Pagu, 6/7: 1-2, 1996.

MAGGIE, Y. A ilusão do concreto: análise do sistema de classificação racial no Brasil, 1991. Tese para professor titular de Antropologia do Departamento de Ciências Sociais da UFRJ, Rio de Janeiro: Universidade Federal do Rio de Janeiro.

NOGUEIRA, O. Relações raciais em Itapetininga. In: FERNADES, F. \& BASTIDE, R. Relações raciais entre negros e brancos em São Paulo. São Paulo: Anhembi, 1955a.

. Preconceito racial de marca e preconceito racial de origem: sugestão de um quadro de referência para a interpretação do material sobre relações raciais no Brasil. Revista Anhembi, abril 1955b.

PISCITELLI, A. "Sexo tropical”: comentários sobre gênero e "raça" em alguns textos da mídia brasileira. Cadernos Pagu, 6/7: 9-34, 1996.

ROSA-RIBEIRO, F. Racism, mimesis and anthropology in Brazil. Critique of Anthropology, 20(3): 221-241, 2000.

SALEM, T. O princípio do anonimato na inseminação artificial com doador (IAD): das tensões entre natureza e cultura. Physis-Revista de Saúde Coletiva, 5(1): 60, 1995. 


\section{IDENTIDADE GENÉTICA NO DEBATE SO- BRE O ESTATUTO DE FETOS E EMBRIÕES}

Naara Luna

\section{Introdução}

Este capítulo aborda o debate público sobre o estatuto de fetos e embriões no tocante ao uso de argumentos fundamentados em dados genéticos para descrever a condição desses entes. Para tanto, a investigação se apoia na documentação referente a duas ações no Supremo Tribunal Federal (STF): a Ação de Inconstitucionalidade 3.510 (ADI 3.510) e a Arguição de Descumprimento de Preceito Fundamental (ADPF) n. 54 (ADPF 54). A ADI 3.510 questiona o artigo $5^{\circ}$ da Lei de Biossegurança, que autorizou o uso de embriões restantes de reprodução assistida para a produção de células-tronco embrionárias. Já a ADPF 54 pleiteia a autorização para a antecipação de parto de anencéfalo sem necessidade de recurso na Justiça. Embora as ações sejam referentes a contextos distintos, a pesquisa com células-tronco e o aborto, especificamente a ampliação dos permissivos para tal intervenção, a oposição a essas práticas remete ao discurso pró-vida segundo o qual a vida se inicia na fecundação, ponto que coincide com o estabelecimento da condição de pessoa.

Este texto explora de que modo dados genéticos são utilizados para fundamentar posições pró-vida ou descartá-las, argumentando contra ou a favor da possibilidade do uso de embriões em pesquisa ou da antecipação do parto de anencéfalos. Trata-se de processos distin-

1 Este capítulo traz conclusões relacionadas ao projeto de pesquisa Do aborto à pesquisa com células-tronco embrionárias: o estatuto de embriões e fetos e o debate sobre direitos humanos no Brasil, financiado pelo Auxílio à Pesquisa APQ1 da Faperj na UFRRJ. 
tos, liderados por diferentes atores sociais - o movimento feminista, no caso do aborto, e a comunidade científica, no tocante à pesquisa com células-tronco - que são unidos no discurso pró-vida. Atribui-se a enunciação desse discurso a atores do campo religioso, mas essa fala também parte de outros setores. A comunidade científica surge como um dos atores principais em ambos os casos, testemunhando acerca do estatuto desses entes, mas também estão presentes juristas (em particular no julgamento da ADI 3.510 no Supremo e na condução da audiência pública da ADPF 54), parlamentares e representantes de movimentos sociais.

\section{A ADI 3.510}

A Lei de Biossegurança, em seu artigo $5^{\circ}$, autorizou a extração de células-tronco de embriões humanos produzidos para reprodução assistida que fossem inviáveis ou que estivessem congelados há três anos ou mais no momento de aprovação da lei, sempre com autorização dos "genitores". A lei foi aprovada pelo Congresso Nacional em março de 2005 e sancionada pelo presidente Lula em outubro do mesmo ano. Antes da sanção, no mês de maio, o então Procurador-geral da República Cláudio Fonteles ajuizou a Ação de Inconstitucionalidade 3.510 (ADI 3.510), questionando a constitucionalidade do artigo $5^{\circ}$ da Lei de Biossegurança com o argumento de que este feriria a inviolabilidade do direito à vida (artigo $5^{\circ}$ da Constituição) e a dignidade humana, fundamento do estado democrático de direito (artigo $1^{\circ}$, inciso III). O autor da ação foi constantemente acusado na imprensa de ter sido motivado por ser católico. A Igreja Católica desde o início entrou como parte interessada do processo.

\section{A petição inicial da ADI 3.510}

A petição apresenta o questionamento do artigo $5^{\circ}$ da Lei de Biossegurança e mostra a fundamentação constitucional. A tese central da petição afirma que "a vida humana acontece na e a partir da 
fecundação" (p. 2, negrito original). Tal afirmação é fundamentada em várias citações de depoimentos, artigos científicos e mesmo de um livro publicado pela Pastoral Familiar da CNBB, Vida: o primeiro direito da cidadania, em que cientistas defendem a tese do início da vida na fecundação. A petição também salienta os avanços mais promissores com células-tronco adultas e a existência de leis de proteção aos embriões em outros países. Após argumentar sobre a inconstitucionalidade do artigo $5^{\circ}$, a petição propõe a realização de uma audiência pública no STF e sugere o nome de nove cientistas, seis dos quais têm depoimentos integrando a petição. Dos oito cientistas citados diretamente na petição inicial, cinco mencionam a constituição genética própria para definir o embrião como uma vida ou um ser humano em desenvolvimento. Destacam-se alguns exemplos a seguir:

Desde o primeiro momento de sua existência esse novo ser já tem determinado as suas características pessoais fundamentais como sexo, grupo sanguíneo, cor da pele e dos olhos, etc. É o agente de seu próprio desenvolvimento, coordenado de acordo com seu próprio código genético. (Dr. Dernival da Silva Brandão, especialista em ginecologia e professor emérito da UFF, apud petição, p. 3)

Mesmo não sendo possível distinguir nas fases iniciais os formatos humanos, nessa nova vida se encontram todas as informações, que se chama "código genético", suficientes para que o embrião saiba como fazer para se desenvolver. Ninguém mais, mesmo a mãe, vai interferir nesses processos de ampliação do novo ser. (Dr. Dalton Luiz de Paula Ramos, livre docente pela Universidade de São Paulo, professor de bioética da USP, apud petição, p. 3-4)

No momento da fecundação, $[\ldots]$ a nova célula formada, chamada zigoto, $[\ldots .$.$] inicia um novo programa ditado por esta nova com-$ binação de genes, comanda de forma autônoma todas as reações que o levarão a implantar-se no útero materno. [...] Portanto, todo o desenvolvimento humano tem como marco inicial a fe- 
cundação e, após esse evento, tem-se um ser humano em pleno desenvolvimento e não somente um aglomerado de células com vida meramente "celular". (Dra. Claudia M. C. Batista, professora adjunta da UFRJ e pós-doutorada pela Universidade de Toronto, apud petição, p. 10)

Após citar esses depoimentos, a petição conclui:

- que a vida humana acontece na, e a partir da fecundação: o zigoto, gerado pelo encontro dos 23 cromossomos masculinos com os 23 cromossomos femininos;

- partir da fecundação, porque a vida humana é contínuo desenvolver-se;

- contínuo desenvolver-se porque o zigoto, constituído por uma única célula, imediatamente produz proteínas e enzimas humanas, é totipotente, vale dizer, capacita-se, ele próprio, ser humano embrionário, a formar todos os tecidos, que se diferenciam e se auto-renovam, constituindo-se em ser humano único e irrepetível.

- a partir da fecundação, a mãe acolhe o zigoto, desde então propiciando o ambiente a seu desenvolvimento, ambientação que tem sua etapa final na chegada ao útero. Todavia, não é o útero que engravida, mas a mulher, por inteiro, no momento da fecundação. (p. 10-11)

Os argumentos são usados para estabelecer que o embrião é vida humana e que o artigo $5^{\circ}$ da Lei de Biossegurança não observa a inviolabilidade do direito à vida e faz ruir o fundamento do estado democrático de direito que radica na preservação da dignidade da pessoa humana.

Está patente em todo o texto da petição e em sua justificativa a dependência da argumentação fundamentada em dados biológicos para demonstrar o estatuto do embrião humano como pessoa e vida humana. Essa figura de pessoa é o indivíduo descrito por Dumont 
(1992) como ser associal e autônomo, referência de valor na cultura ocidental moderna. A singularidade e a autonomia caracterizam esse

\section{A audiência pública com especialistas}

Em 20 de abril de 2008, ocorreu a primeira audiência pública na história do STF, reunindo especialistas para definir um conceito operacional jurídico para vida humana. A petição já pleiteava a audiência pública e indicava especialistas. Dos 22 expositores, 11 eram contrários à pesquisa com embriões, portanto questionavam a constitucionalidade da lei, e 11 eram favoráveis. Apenas uma expositora não pertencia à área biomédica: uma antropóloga com pós-doutorado em bioética. A CNBB também indicou especialistas. A exposição ocorreu em dois blocos. A transcrição da audiência pública de instrução ao STF é a fonte dos comentários abaixo.

No primeiro bloco (os favoráveis ao uso de embriões em pesquisa), as referências à genética disseram respeito principalmente a doenças genéticas em pacientes, que poderiam ser beneficiados com o desenvolvimento de terapias a partir da pesquisa com células-tronco embrionárias. Também se registrou a menção a alterações genéticas nos embriões congelados, o que diminuiria sua viabilidade para serem implantados e gerarem a gestação.

Gostaria de lembrar que, quando analisamos geneticamente essas células do embrião pré-implante, apenas $20 \%$ dos embriões têm condições totais de higidez para serem implantados. O resto tem algum tipo de anomalia genética que pode trazer danos no futuro. (Professor Ricardo Ribeiro dos Santos, p. 51 transcrição ADI 3.510)

Os favoráveis ao uso de embriões em pesquisa os descrevem no estágio propício para extração de células-tronco como amontoado de células, imagens que contrariam a representação de humanidade apresentada pelo grupo adversário. 
As primeiras menções a DNA e a cromossomos são feitas por opositores ao uso de embriões em pesquisa. O objetivo desse grupo é demonstrar que a vida começa na fecundação, conforme consta na petição que abre o processo de inconstitucionalidade. A professora Lenise Aparecida Martins Garcia, comentando sobre o ciclo de vida dos seres vivos e o Projeto Genoma Humano, afirma:

Ele vai passando pelas diversas fases que a natureza preparou. E onde tudo isso está programado? No DNA de cada um. (p. 59) [...] Sabemos que são cerca de trinta mil genes que vêm no espermatozóide; os correspondentes trinta mil que estão no óvulo e, quando se juntam, esses dois conjuntos de genes formam um ser único e irrepetível. [...] Já estão definidas, aí, as características genéticas desse indivíduo; já está definido se é homem ou mulher nesse primeiro momento. Assim, quando falamos em montinho de células, poderíamos dizer montinho de células masculinas ou montinho de células femininas, porque aquilo já é um menininho ou uma menininha. [...] Tudo isso já está definido, no seu programa genético, neste primeiro momento da fecundação (p. 60). [...] Também já estarão aí as tendências herdadas: o dom para música, pintura, poesia. Tudo isso já está ali na primeira célula formada. O zigoto do Mozart já tinha dom para música e o do Drummond, para poesia. Tudo já está lá. É um ser humano irrepetível. Ejá se pode fazer a "impressão digital" genética, a que se usa nos testes de paternidade. (p. 61)

Após afirmar que a identidade da pessoa permanece ao longo de seu desenvolvimento, a doutora. Cláudia Maria de Castro Batista diz:

E todo o programa de desenvolvimento, então, é disparado a partir da fertilização. É [...] uma célula em que metade dos cromossomas paternos e metade maternos fazem com que essas células se reprogramem no momento da fertilização e recomece todo um projeto de construção de um novo indivíduo da espécie humana" (p. 64). [...] O embrião de três dias já tem uma autonomia funcional, que dá uma unidade a todo um organismo como 
um todo. Esse montinho é um todo que se comporta funcional e metabolicamente como um único ser, um único organismo e que se autodireciona no sentido de gerar um novo indivíduo ( $p$. 67), enquanto se pode deixar uma neuroesfera, um montinho de células, a partir de uma célula-tronco do cérebro, quantos dias quiser. Ela pode se dividir, até determinado ponto, mais de uma vez, até que se esgotem os componentes do meio de cultura, e, aí, ela morrerá (p. 68). [...] Do ponto de vista biológico, a formação e o desenvolvimento do embrião humano é um processo gradual, contínuo e coordenado desde o momento da fertilização, momento em que novo organismo humano está constituído com sua capacidade intrínseca de desenvolver-se, por si só, no indivíduo humano adulto (p. 70s.). [...] Por fim, o respeito ao embrião humano, como pessoa humana, deriva da realidade da força da constatação biológica e da argumentação racional. O direito à vida e à integridade física, desde o primeiro momento da existência, é o princípio de igualdade que deve ser respeitado (p. 71).

A professora Lilian Piñero Eça abordou o diálogo do embrião e sua mãe:

Falamos até agora sobre esse zigoto, em que temos realmente o programa genético de todas as nossas características até o fim da nossa vida. No entanto, considero muito importante falar aqui, hoje, que não só temos um programa desde a primeira divisão do zigoto, como é muito importante lembrar que, além de já termos essa programação, o embrião já se comunica com a sua própria mãe, através daquilo que não se enxerga, macroscopicamente, mas que enxergamos através das nossas moléculas marcadas. (p. 72)

Continuando, Lílian Eça refere-se à genética no tocante à mulher que porta o embrião:

Toda mulher prepara, com essas substâncias, duas a três horas após a fecundação, o ninho para poder receber o embrião que será nidado no décimo quarto dia em seu útero. Desde o primeiro 
momento, ela prepara o seu ninho. Realmente isso é a comunicação humana. Diante disso, essa progesterona altera todo esse programa, todos os genes das 75 trilhões de células dessa mãe, duas a três horas após a fecundação. (p. 73)

O professor Antônio José Eça fala da transcrição gênica no embrião:

Já no início do desenvolvimento, desde o primeiro dia de vida, a célula humana, o zigoto, está pré-programado geneticamente com a programação da qual faz parte a transcrição gênica, que começará no estágio de duas células - talvez tenhamos a oportunidade de falar um pouco da transcrição gênica. Essa célula está determinada a se diferenciar em um tipo particular de célula, por exemplo, a célula nervosa, mesmo que suas características finais ainda não sejam identificáveis (p. 101). [...] A divisão continuará e a progressão será geométrica, e cada uma das vias de sinalização será utilizada repetidamente desde o início do desenvolvimento, ativando, cada uma delas, os grupos de genes-alvo, em cada um dos diferentes objetivos de transformação e formação tecidual. (p. 102)

Dra. Elizabeth Kipman Cerqueira foi uma das expositoras mais incisivas:

A nossa discussão aqui não é o início da vida humana, mas quando a vida de um novo indivíduo tem início. [...] Então, a definição de ser vivo, pela Biologia moderna, é aquele ser que tem um início e, a partir do seu próprio potencial, da sua ipseidade, da sua imanência, daquilo que lhe é próprio, desenvolve-se num programa recebido através de um material genético (p. 108). [...] Começa a vida do novo ser com a fecundação. A gravidez não é um processo essencial da reprodução, embora, até agora, indispensável na mulher, como nos demais mamíferos, para a plenitude do desenvolvimento do concepto. (p. 109)

Após situar a discussão como o início da vida de um ser humano na fecundação, ela rejeita a gravidez como fato essencial na reprodu- 
ção humana. A identidade do embrião vem de um processo intrínseco que demonstra sua essência humana:

Repetimos: a identidade do embrião não provém do observador, vem de um processo de autoconstrução e de autodesenvolvimento, vem de algo que lhe próprio, intrínseco - repito -, imanente, a sua ontogênese pertence a ele mesmo. Assim, ele não pode ser definido - o embrião, a sua vida - por suas propriedades funcionais ou estruturais (p. 112). Ele se torna, na aparência, aquilo que já é desde o início. Portanto, ele traz uma unidade interior, essa unidade que é a vida e que o faz um ser vivo. (p. 113)

Cerqueira continua descartando vários argumentos usados para contestar que o embrião seja uma pessoa ou uma vida. Reproduz-se aqui apenas o que diz respeito à identidade genética como é o caso do surgimento de gêmeos idênticos (monozigóticos):

Os fatores todos que influenciam para aparecer o gêmeo monozigoto. Mas, sem dúvida, a individualidade não quer dizer que é singularidade. O substrato do DNA não quer dizer que é o embrião, mas, a partir dele, pode sair outro semelhante a ele que pode estar determinado desde o início. (p. 120)

Em seguida, ela menciona um quadro de critérios para o início de um novo ser humano, indica a fecundação como o único correto e descarta qualquer noção gradualista do início do ser humano:

Se eu disser que ele vem num determinado momento do seu desenvolvimento, $[\ldots]$ estarei apelando para concepções de Aristóteles, que colocará uma alma $[\ldots]$ no momento em que o embrião estiver com dez semanas. [...] Aristóteles, Tomás de Aquino e Agostinho não conheciam biologia. Estamos falando de início de um novo ser humano a partir daquilo que a biologia e a genética nos ensinam (p. 123). [...] Existe um único critério de referência de certeza. Por que não admitir a coincidência quanto à referência biológica, jurídica e política? (p. 124) 
Seu objetivo é unificar todas as referências do início do ser humano à base biológica ou genética cujo marco é equiparado à fecundação, e daí fazer a correspondência com o plano jurídico e o político.

O professor Rodolfo Acatauassu Nunes cita a definição do início da vida de livros de biologia molecular: "Logo após a fecundação a união da informação genética proveniente dos dois gametas provê ao novo organismo toda a informação genética necessária para a formação dos diferentes tipos celulares que futuramente irão compor o organismo adulto" (p. 127). Ele afirma: "O zigoto, senhores, é uma estrutura extremamente complexa, a síntese do organismo humano dentro de uma célula" (p. 131). Após mencionar diversos estágios do desenvolvimento, ele se pergunta se na fase anterior esses tecidos estariam mortos: "Será que a vida começaria aqui? [...] Mas e tudo o que aconteceu antes? Não era humano? Eram células e tecidos mortos? Onde mais a vida humana começaria?" (p. 131). "O fato é que a vida humana iniciou-se na fecundação" (p. 132). Mais uma vez é descartado o desenvolvimento gradual e se resume a vida humana ao zigoto, formado na fecundação.

O professor Dalton Luiz de Paula Ramos retoma o argumento: "O fato é que, no momento da junção desses dois gametas, uma identidade geneticamente única formou uma nova vida humana" ( $p$. 146). Ele qualifica a vida humana como a vida humana "como um processo contínuo, coordenado e progressivo" (p. 150):

É contínuo porque tem um ponto de início, isto é, o surgimento de uma nova vida humana, um novo ser, com identidade própria, distinto de todos os outros. Contínuo, ainda, porque tem um ponto de fim. [...] É coordenado [...] por ser auto-suficiente no próprio projeto; possuidor de todas as instruções para se realizarem os processos biológicos necessários à continuidade dessa vida. É progressivo porque [...] ultrapassada uma etapa de desenvolvimento, passa, em condições normais, à etapa seguinte, sem regressos; evoluções que vão compor uma biografia. (p. 150) 
Ramos usa o argumento da essência inicial: "se retrocedermos nessa cronologia, chegaremos à constatação de que, já naquele primeiro instante, se configuram todas essas categorias que descrevi" (p. 151). Ele descarta argumentos que questionam o início da vida na fecundação. Serão vistos aqui os relacionados com a genética:

Há vida humana antes dos quinze dias, visto que o cérebro ainda não começou a se formar? [...] há vida humana antes dos quinze dias. Sabemos que o cérebro se desenvolve porque o embrião o faz desenvolver. Não é o inverso. [...] Desenvolve-se por meio dos genes que estão dentro do embrião desde o primeiro momento da fecundação. (p. 152)

Segundo Ramos, o não reconhecimento do embrião como vida humana seria característica de barbárie:

Os bárbaros exigiam que os recém-nascidos demonstrassem ter atributos humanos para serem plenamente reconhecidos no seio da comunidade social (p. 153). [...] a sociedade até poderá assumir um critério de "humanidade" que se baseie na potência e viabilidade do organismo, porém não poderá negar que essa opção: 1 - contraria o dado biológico, que caracteriza o "humano" por seus atributos genéticos e por sua expressão orgânica; 2 - traz o perigo do casuísmo e da própria negação da vida com o direito universal. (p. 154, ênfase acrescentada)

A definição de humanidade fundamentada em dados biológicos, ponto característico da cosmologia ocidental moderna (Laqueur, 1992), é exemplificada na fala acima.

Dr. Rogério Pazetti aborda o tema "Nossa vida começa com a fecundação de um óvulo por um espermatozoide e a formação da primeira célula chamada ovo ou zigoto". Ele projeta na tela citações de diversos cientistas: "Quem é o maestro que está regendo essa fascinante orquestra? É o genoma, que foi constituído no momento da fecundação dentro daquela primeira célula que um dia fomos. 
Nesse momento (fecundação) é formada a receita única, inédita, de uma pessoa" (sublinhado original, p. 156 e ss.). Pazetti contesta o argumento do grupo opositor sobre a forma do embrião: "O e embrião humano NÃO é um AMONTOADO DE CÉLULAS. São células [...] ligadas umas às outras, com informações precisas [...] desde a primeira divisão, cada qual com a sua informação para seguir a própria diferenciação, desde o seu primeiro instante" (ênfase original, p. 157 e ss.).

Todos argumentam sobre o início da vida na fecundação, mas o argumento da individualidade do embrião é bastante repetido, tanto com respeito ao programa de desenvolvimento, ponto ligado à discussão genética e do DNA, mas também com respeito à autonomia diante da mãe. Trata-se de dois indivíduos, conforme essa argumentação, contudo a mulher é subordinada como meio para desenvolvimento do embrião. Outro ponto reiterado é a firme negação do desenvolvimento humano como gradual e em etapas. A defesa da tese que a fecundação é o momento inaugural do estatuto do humano contraria qualquer tese gradualista que supõe a aquisição desse estatuto ao longo do desenvolvimento, posição dos expositores favoráveis ao uso de embriões em pesquisa, e não de uma só vez. ${ }^{2}$ No zigoto, existe desde o princípio a síntese de um ser humano, síntese esta argumentada a partir da existência do genoma ou DNA individual. Na cosmologia ocidental moderna, oriunda do Iluminismo, encara-se o mundo físico ou natural como o fundamento da realidade (cf. Laqueur, 1992). Por isso a ênfase no dado biológico e a correspondência deste com o aspecto político e jurídico, ponto defendido pela Dra Elizabeth Kipman Cerqueira. O dado biológico deve resumir-se à fecundação

2 Nas noções essencialistas da emergência da condição de pessoa, o episódio da concepção geralmente é o marco inicial, e nas noções gradualistas, a condição de pessoa se instala ao longo do desenvolvimento. Segundo Strathern (1992: 174), essas posições se baseariam em uma visão evolucionista do tempo, identificada com a posição gradualista, e em uma visão episódica do tempo, representando um início radical, o que constituiria a visão
essencialista. 
e à constituição genética individual em potência, no entanto.

Os cientistas favoráveis ao uso de embriões para extração de células-tronco apresentam marcos distintos para o início da vida: a formação do primórdio do sistema nervoso (critério simétrico à adoção da morte encefálica como parâmetro para o fim da vida) e a nidação ou presença do embrião no útero materno são os mais citados, além de descrições relativistas em que a vida seria um processo presente desde os gametas. A antropóloga Débora Diniz contesta o argumento principal do grupo contrário à pesquisa com células embrionárias:

Considerar o marco da fecundação como suficiente para o reconhecimento do embrião, como detentor de todas as proteções jurídicas e éticas disponíveis a alguém, após o nascimento, implica assumir que: primeiro, a fecundação expressaria não apenas um marco simbólico na reprodução humana, mas a resumiria euristicamente; uma tese de cunho essencialmente metafísico. (p. 205)

Diniz levanta o problema central concernente ao estatuto do embrião e do feto, cerne do discurso pró-vida que considera o embrião independente de seu contexto:

A refutação da premissa da tese de potencialidade do embrião permite devolver o debate sobre pesquisa com células-tronco para o campo da ética da pesquisa científica, retirando-o da controvérsia moral sobre início da vida. Esse foi um deslocamento argumentativo provocado pela ADI, cujo resultado forçaria o enfrentamento, por esta Corte, de uma questão política fundamental à democracia brasileira, mas desnecessário para avaliação da constitucionalidade da Lei $\mathrm{n}^{0} 11.105$, que é o estatuto do embrião humano e, conseqüentemente, a legislação brasileira sobre aborto. (p. 208)

Ela contrasta a proibição do uso de embriões congelados em experimento com a permissão para pesquisas clínicas em seres humanos que não desfrutarão de seus benefícios: "No entanto, a ADI, ao proibir 
a pesquisa com embriões humanos inviáveis, pressupõe que a vida de embriões congelados deva ser passível de maiores proteções que quaisquer outros grupos, inclusive as crianças com câncer" (p. 211).

A antropóloga explicita o problema religioso que é renegado pelos defensores da vida ao dizerem que argumentam cientificamente sobre o estatuto do embrião:

O julgamento da constitucionalidade do artigo $5^{\circ}$ deve ser avaliado sob o marco ético da pesquisa científica com humanos e partes do corpo humano. O deslocamento do debate da ciência para a reprodução, tal como proposto, impede que se avalie com razoabilidade a ética da pesquisa com embriões inviáveis e congelados, pois o tema do debate moral sobre reprodução humana é objeto de intensa controvérsia religiosa em nossa sociedade. (p. 212)

Afirmando que o problema deve ser tratado como questão de ética de pesquisa com humanos, a antropóloga alerta para a possibilidade de se afetar a legislação sobre aborto no Brasil, caso o Supremo venha a reconhecer o estatuto de pessoa desde a fecundação, concedendo ao embrião todos os direitos:

A pergunta sobre quando a vida humana tem início diz respeito ao debate político sobre aborto e direitos reprodutivos. Uma possível resposta do Supremo Tribunal Federal à tese da ADI poderia trazer implicações para o debate político e sanitário sobre aborto, com repercussões imediatas para a garantia de direitos reprodutivos e promoção de saúde das mulheres. (p. 212)

O debate no Supremo, porém, trilhou outros caminhos, menos afeitos à argumentação biológica do que a audiência com especialistas.

\section{Julgamento no Supremo da ADI 3.510}

O julgamento no STF começou com uma primeira sessão em 5 de março de 2008, na qual se manifestaram apenas o relator do pro- 
cesso, ministro Carlos Ayres Britto, e a ministra Ellen Gracie, então presidente do STF. Nessa sessão, o ministro Carlos Menezes Direito pediu vista do processo. O julgamento foi interrompido e retomado em duas sessões, em 28 e 29 de março de 2008 . Na votação, seis se manifestaram pela constitucionalidade da lei e cinco questionaram parcialmente a constitucionalidade. Desses cinco, três aderiram ao argumento da petição de que o uso de embriões em pesquisa feria o direito à vida, mas dois apenas sugeriram criar outros órgãos de fiscalização e supervisão da pesquisa. A seguir analiso os votos dos ministros que se aprofundaram no problema da identidade do embrião a partir da biologia ou genética. As citações são baseadas nos votos escritos.

O relator, ministro Carlos Ayres Britto, ressalta o caráter interdisciplinar do tema da ADI 3.510, objeto de várias ciências. Comenta que a lei em questão é "um conjunto normativo que parte do pressuposto da intrínseca dignidade de toda forma de vida humana, ou que tenha potencialidade para tanto, ainda que assumida ou configurada do lado de fora do corpo feminino (caso do embrião in vitro)" ( $p$. 19). A maior parte das menções que o relator faz à dimensão genética diz respeito a doenças que poderiam ser alvo de terapias com células-tronco. Britto cita do Código Civil: "A personalidade civil da pessoa começa do nascimento com vida; mas a lei põe a salvo, desde a concepção, os direitos do nascituro", embora saliente que personalidade é predicado da pessoa em "dimensão biográfica, mais do que simplesmente biológica" (p. 22). Britto profere uma definição jurídica provisória: "vida humana já revestida do atributo da personalidade civil é o fenômeno que transcorre entre 0 nascimento com vida e a morte" (p. 24, ênfase original). O relator afirma que a Constituição não diz quando começa a vida humana e quando se reporta a direitos da pessoa humana: "está falando de direitos e garantias do indivíduo-pessoa. Gente. Alguém” (p. 24 , ênfase original). Britto conclui que a Constituição "não faz de todo 
e qualquer estádio da vida humana um autonomizado bem jurídico, mas da vida que já é própria de uma concreta pessoa, porque nativiva e, nessa condição, dotada de compostura física ou natural" (p. 26, ênfase original). Reconhece que o Código Civil põe a salvo os direitos do nascituro desde a concepção, "direitos de quem se encontre a caminho do nascimento" (p. 31, ênfase original). Ressalta que o bem jurídico a tutelar contra o aborto é "um organismo ou entidade pré-natal, quer em estado embrionário, quer em estado fetal, mas sempre no interior do corpo feminino" (p. 32, ênfase original). Com respeito ao aborto: "O que traduz essa vedação do aborto não é outra coisa senão o Direito Penal brasileiro a reconhecer que, apesar de nenhuma realidade ou forma de vida pré-natal ser uma pessoa física ou natural, ainda assim faz-se portadora de uma dignidade que importa reconhecer e proteger" (p. 32, ênfase original). O relator afirma que a realidade de pessoa humana não se antecipa: "Donde não existir pessoa humana embrionária, mas embrião de pessoa humana" (p. 34, ênfase original). Britto reconhece que:

O início da vida humana só pode coincidir com o preciso instante da fecundação de um óvulo feminino por um espermatozóide masculino. Um gameta masculino (com seus 23 cromossomos) a se fundir com um gameta feminino (também portador de igual número de cromossomos) para a formação da unitária célula em que o zigoto consiste. (p. 35, ênfase original)

Mas Britto diferencia o início da vida e a constituição da pessoa: "início de vida é uma realidade distinta daquela constitutiva da pessoa física ou natural; (...) porque assim é que preceitua o Ordenamento Jurídico Brasileiro" (p. 36, ênfase original). Sua justificativa não vem de convicção, mas da lei brasileira.

Com respeito à genética, o relator observa que a "linha de partida genética" do embrião não é suficiente sem a transferência para o útero. Esse embrião, "aprisionado in vitro, empaca nos primeiros degraus do que seria sua evolução genética. Isto por se achar im- 
possibilitado de experimentar as metamorfoses de hominização que adviriam de sua eventual nidação" (p. 42, ênfase original). O relator concebe o embrião como entidade biológica ou material genético: “o tipo de embrião a que se refere a lei não precisa da cópula humana nem do corpo feminino para acontecer como entidade biológica ou material genético" (p. 42). O ministro fala que a viabilidade genética dos embriões não obriga o casal à transferência de todos nos tratamentos de reprodução assistida, reconhecendo que a produção de embriões excedentes é contingência da fertilização in vitro. Britto considera que, inexistindo "o dever legal do casal quanto a esse cabal aproveitamento genético", restariam três alternativas à Lei de Biossegurança: manter os embriões congelados ("pena de prisão em congelados tubos de ensaio"), continuar o descarte pelas clínicas ou seu aproveitamento como autoriza o artigo $5^{\circ}$ da lei (p. 58). O relator usa em seguida a analogia com o parâmetro de morte encefálica e descarta a atribuição de personalidade jurídica ao embrião situado nos marcos da Lei de Biossegurança com base no argumento da ausência de cérebro:

Faltam-lhe todas as possibilidades de ganhar as primeiras terminações nervosas que são o anúncio biológico de um cérebro humano em gestação. [...] Se permanecer assim inescapavelmente confinado é algo que jamais será alguém. Não tem como atrair para sua causa a essencial configuração jurídica da maternidade nem se dotar do substrato neural que, no fundo, é a razão de ser da atribuição de uma personalidade jurídica ao nativivo. (p. 61, ênfase original)

O relator ratifica a afirmação antes provisória: "vida humana já rematadamente adornada com 0 atributo da personalidade civil é o fenômeno que transcorre entre o nascimento com vida e a morte cerebral" (p. 62, ênfase original). E refuta a inconstitucionalidade do artigo $5^{\circ}$ da Lei de Biossegurança. Segundo ele, a lei não desrespeita os embriões, mas valoriza as pessoas doentes potenciais 
beneficiárias da pesquisa. Destinar o embrião para pesquisa consiste em dignidade: "Situação em que se possibilita ao próprio embrião cumprir sua destinação de servir à espécie humana?" (p. 71).

Também a ministra Carmem Lúcia Rocha aborda a genética ao discutir a tese da ADI 3.510. Ela confunde como sinônimos embrião e célula-tronco embrionária. Rocha designa a célula de substância genética:

A substância humana aqui considerada consiste no que se denominou embrião, ou célula-tronco embrionária, que se origina após a fecundação de um óvulo por um espermatozóide com a formação da célula ovo, que contém em seu núcleo 46 cromossomos, sendo 23 originários do espermatozóide e os outros 23 do óvulo. Essa célula, substância genética, é resultado da junção de outras duas células humanas e tem a finalidade de gerar todos os tecidos de um indivíduo adulto devido a sua pluripotencialidade. (p. 20)

Segundo a ministra, a pesquisa e o tratamento devem se basear nos princípios da necessidade do experimento científico, da avaliação dos potenciais e benefícios e do consentimento informado dos envolvidos, além da integridade do patrimônio genético: "integridade do patrimônio genético, proibindo-se a manipulação em genes humanos voltada para mudanças na composição do material genético com o fim de melhorar determinadas características fenotípicas" (p. 21e ss.).

A ministra defende que a utilização de células-tronco embrionárias para pesquisa e tratamentos futuros valoriza a dignidade humana, o que é preferível ao descarte:

Se a célula-tronco embrionária, nas condições previstas nas normas agora analisadas, não vierem a ser implantadas no útero de uma mulher, serão elas descartadas. [...] Estaríamos não apenas criando um lixo genético, como, o que é igualmente gravíssimo, estaríamos negando àqueles embriões a possibilidade de se lhes garantir, hoje, pela pesquisa, o aproveitamento para a dignidade da vida. (p. 26). 
Assim a ministra adota a retórica de que, sem a transferência para o útero, o outro destino possível seria o lixo. Rocha pede mais severidade no regramento da fiscalização das entidades dedicadas à pesquisa e à manipulação de material genético. Nesse sentido, cita o artigo 10 da Declaração dos Direitos sobre o Genoma Humano da Unesco:

Nenhuma pesquisa ou suas aplicações relacionadas ao genoma humano, particularmente nos campos da biologia, da genética e da medicina, deve prevalecer sobre o respeito aos direitos humanos, às liberdades fundamentais e à dignidade humana dos indivíduos ou, quando for aplicável, de grupos humanos. (p. 31)

A ministra questiona que a Constituição impeça os doadores do material genético a disporem de autonomia para consentir sobre o aproveitamento das "células-tronco embrionárias" (sic), referindo-se à autorização para o uso de embriões congelados em pesquisa. Ela adverte para não se exagerar quanto às prerrogativas atribuídas ao embrião:

Também não se pretenda que a "liberdade" daquela substância humana em estado de congelamento seja superior à daqueles que a ele deram origem e que verão, nas condições legalmente estipuladas, uma de duas alternativas: o descarte do material ou a sua utilização para o que poderá vir a ser o bem da vida, por meio da pesquisa e, quando sobrevierem os resultados científicos consolidados, do tratamento que a partir de então se terá. (p. 43-44)

Os embriões seriam "substância humana em forma de congelamento", substância que não possui liberdade superior à daqueles que a geraram. A ministra, portanto, nega a identidade de pessoa ao embrião extracorporal e refere-se à genética no tocante à restrição de manipulação da substância humana. O embrião pode ser substância genética humana, mas isso não lhe confere o estatuto de pessoa. 
Outra contribuição significativa para esse debate vem do ministro Cezar Peluso, que debate a caracterização do embrião como pessoa:

Sua caracterização, em termos absolutos ou relativos, como pessoa, pois, a despeito de o código genético completo, enquanto conjunto das disposições suficientes para, sob certa condição externa, se desenvolver e transformar em ser humano autônomo, já estar inscrito no embrião, não se pode reduzir a complexidade da pessoa humana como organismo vivo e, sobretudo, como sujeito de direito, ao aspecto puramente biológico de sua mera completude ou perfeição genética. (p. 12)

Discordando da argumentação do grupo contrário ao uso de embriões em pesquisa, para Peluso a complexidade da pessoa humana não se reduz à dimensão genética. Segundo o ministro: "embriões isolados, que, posto corporifiquem patrimônio genético humano, não têm vida no sentido e como objeto da tutela constitucional" (p. 13, n. 16). O ministro afirma a tese de que "o reconhecimento da posse desse material genético de pessoa não é suficiente para lhe fundar e estender idêntico valor moral e jurídico" (p. 17).

Peluso destaca a importância da transferência do embrião para o útero:

[...] sem [...] introdução do embrião em útero de mulher, o processo não retoma o curso geneticamente programado e, pois, não chega ao estágio em que pode atualizar-se a potência vital naquele contida. Logo, a fixação do óvulo fecundado na parede uterina é condição sine qua non de seu desenvolvimento ulterior e, como tal, constitui critério de definição do início da vida, concebida como processo ou projeto. (p. 26)

Os embriões excedentes não são sujeitos de direito à vida, nem têm a expectativa desse direito. Independentemente "das aptidões virtuais inscritas no programa genético do embrião" antes que seja implantado, não se pode falar de paternidade, apenas da disponi- 
bilidade jurídica do casal sobre o embrião (p. 27). A doação com fins de pesquisa após consentimento informado implica "autêntica, automática e irrevogável renúncia à faculdade de produzirem vida a partir do material genético de que dispuseram" (p. 32). Peluso diz que a interpretação com respeito ao embrião em laboratório levanta o problema de outras técnicas como o DIU e a pílula do dia seguinte, "que provocam interrupção do fluxo contínuo do ciclo vital, que deixa de seguir o curso autônomo geneticamente predeterminado da evolução de uma subjetividade singular" (p. 34). A identidade se adquire ao longo do ciclo vital; na interrupção, isso não ocorre.

Três ministros do STF acataram a tese da ADI 3.510, segundo a qual a extração de células-tronco de embriões restantes de reprodução assistida feriria o direito à vida e o princípio da dignidade humana. Os três ministros pleiteiam como fonte para células-tronco a extração de um único blastômero, resguardando o embrião restante a fim de evitar a destruição desses entes. Dois ministros se valeram de argumentação genética para fundamentar suas posições: Carlos Menezes Direito e Ricardo Lewandowski. O ministro Eros Grau defende que o embrião em laboratório faz parte do gênero humano, tendo a proteção de sua dignidade garantida pela Constituição, que lhe assegura o direito à vida, e não se estendeu em argumentação biológica nem genética.

O ministro Menezes Direito adverte contra diversos riscos implicados na aplicação das técnicas de reprodução assistida:

Questões como seleção de sexo, comercialização de gametas e embriões, diagnóstico genético pré-implantação, clonagem reprodutiva, aperfeiçoamento genético, cisão de embriões, criação de embriões para fins de pesquisa e experimentos com quimeras mostram que há um universo de possibilidades e riscos que não pode ser desprezado. (p. 42)

Ele denuncia os riscos do diagnóstico genético pré-implantação de embriões (PGD) em particular no tocante às dimensões eugênicas 
dessa técnica "em que se torna possível selecionar geneticamente aqueles que mereçam seguir adiante, descartando os demais porque portadores de defeito genético" (p. 42). O ministro segue falando da importância do tratamento jurídico dos desiguais como iguais: "A busca da eugenia, da raça pura, do ser humano programado em laboratórios, não é, certamente, um ideal para a humanidade. Ao contrário, a diversidade que torna iguais os desiguais e transplanta a noção de igualdade para o tratamento jurídico dos desiguais como iguais na sua diversidade é um valor ético que não pode ser menosprezado" (p. 42).

Carlos Menezes Direito define o embrião como um indivíduo desde a fecundação, argumentando a partir da continuidade da carga
genética:

O embrião é, desde a fecundação, mais precisamente desde a união dos núcleos do óvulo e do espermatozóide, um indivíduo, um representante da espécie humana, com toda a carga genética (DNA) que será a mesma do feto, do recém-nascido, da criança, do adolescente, do adulto, do velho. Não há diferença ontológica entre essas fases que justifique a algumas a proteção de sua continuidade e a outras não. (p. 56). [...] A individualidade decorre de sua distinção com o meio em que vive e de sua autonomia, principalmente de seu projeto de individuação, de seu desenvolvimento, de sua renovação e atualização, através de uma atividade orientada por um programa, o programa genético. (p. 56)

O ministro Direito denuncia a noção de estatuto intermediário baseado em marcos temporais que não a fecundação como instrumental para a violação do embrião:

Há uma dificuldade lógica a desafiar o raciocínio que coloca marcos temporais no desenvolvimento do embrião para fixar o início da vida após a fecundação. É que se de um lado reconhece haver vida no embrião, mas uma vida ainda não humana, para a qual não caberia a proteção do direito constitucional à vida, 
de outro, entende não haver pessoa (personalidade) no embrião, mas the reconhece a proteção da dignidade da pessoa humana. [...] Essa engenhosa solução é compartilhada por boa parte do mundo ocidental para justificar a violação do embrião: um estatuto intermediário, fundado em uma dignidade também intermediária, geralmente associada à ausência de capacidade moral ou racional.

O ministro fundamenta que a personalidade do embrião é um atributo da vida: "É, pois, a vida que regulará a proteção merecida pelo embrião. Não me parece razoável afirmar que a vida sem personalidade não é vida humana, como se a personalidade é que atribuísse a condição de vida e não que fosse um atributo dela" (p. 59). genstituição genética do futuro indivíduo no embrião e do patrimônio
da humanidade:

O embrião é vida humana. Uma vida que se caracteriza pelo movimento de seu próprio e autônomo desenvolvimento [...] O embrião já traz em si toda a carga genética do futuro ser que originará. E mais: traz em si o próprio patrimônio genético da humanidade, toda a sua potencialidade e toda a sua diversidade [...], pelo que sua destruição é muito mais até que a interrupção de uma vida; é o descarte da diversidade, da nossa própria origem, da base que nos sustenta como espécie. (p. 59)

A argumentação do ministro Menezes Direito parte do direito à vida e considera a personalidade um atributo secundário. A constituição genética do embrião e o patrimônio genético da humanidade são os fundamentos para essa definição de vida.

O ministro Ricardo Lewandowski reconhece estarem as pesquisas com células-tronco embrionárias no centro de polêmicas, "porque a obtenção desse material genético exige a destruição de um organismo vivo" (p. 5) e "porque podem levar, se livres de qualquer controle, a resultados desconhecidos, colocando em risco a própria existência da 
espécie humana" (p. 6). Com respeito ao progresso da ciência, Lewandowski cogita direitos de quarta geração na busca pela proteção contra "manipulações genéticas", a invasão de privacidade pelo totalitarismo e a burocracia estatal e privada. Propõe balizas na área de bioética e de direitos humanos sem prejuízo da liberdade de pesquisa (p. 13). Cita documentos internacionais como A declaração universal sobre o genoma humano e os direitos humanos. O artigo 1 dessa declaração da Unesco reivindica o respeito merecido pelo genoma humano, definido como "patrimônio da humanidade", por constituir "a base da unidade fundamental de todos os membros da família humana, bem como de sua inerente dignidade e diversidade" (art. 1) (p. 15).

De modo original em relação a seus colegas e aos especialistas expositores no STF, o ministro Lewandowski defende que a vida começa na concepção, fundamentado nos tratados internacionais em vez da justificativa com base biológica. Ele assinala a variabilidade de posições sobre o começo da vida no campo da ciência. Cita, da Convenção Americana de Direitos Humanos: "Toda a pessoa tem direito que se respeite sua vida. Esse direito deve ser protegido pela lei e, em geral, desde a concepção" (apud voto p. 21, ênfase original). Ele situa o foco do debate no direito à vida: "direito à vida entrevisto como um bem coletivo, pertencente à sociedade ou mesmo à humanidade como um todo, sobretudo tendo em conta os riscos potenciais que decorrem da manipulação do código genético humano" (p. 23, ênfase original). Ao debater o postulado da dignidade da pessoa humana, o enfoque do ministro ultrapassa as pesquisas com células-tronco e o estatuto do embrião para abranger a reprodução assistida e manipulações genéticas de modo amplo: "a disciplina das pesquisas genéticas e das ações de todos os seus protagonistas" (p. 32).

Lewandowski comenta, sobre a indefinição do conceito de inviabilidade dos embriões na Lei de Biossegurança: "a redação do referido dispositivo permite que lhe seja conferida a mais elástica 
das interpretações, ao arbítrio do médico, do biólogo, do geneticista ou mesmo do técnico de laboratório encarregado da realização do diagnóstico pré-implantacional" (p. 43).

$\mathrm{O}$ ministro atribui poderes amplos à técnica do diagnóstico genético pré-implantacional - "detectar a presença de anomalias genéticas ou a possibilidade de desenvolvimento de moléstias graves, incuráveis" - e cita os questionamentos de Renata da Rocha, "tem-se verificado que tal prática vem sendo utilizada como um meio para a escolha de determinados traços genéticos, como por exemplo, a escolha do sexo do bebê, a cor de sua pele, o seu coeficiente intelectual, entre outros atributos" ( $a p u d$, p. 45, ênfase acrescentada). Lewandowski encampa um argumento que atribui poder ao PGD de descobrir características que não são testáveis geneticamente, como o coeficiente intelectual e a cor da pele. O ministro repete a denúncia da eugenia, sendo, o "controle de qualidade dos embriões, incompatível com o Estado Democrático de Direito, cujo cerne é o respeito à dignidade humana, que impede taxativamente todo tipo de discriminação" (p. 45, ênfases originais).

Lewandowski cita legislação internacional que proíbe discriminação pelo patrimônio genético: "Pelos mesmos motivos é que a supra referida Convenção dos Direitos do Homem e da Biomedicina do Conselho da Europa proíbe, no art. 11, qualquer forma de discriminação decorrente do patrimônio genético de uma pessoa" (p. 46). Por fim ele comenta o Decreto 5.591, de 22 de novembro de 2005, que regulamenta dispositivos da Lei de Biossegurança e define os embriões inviáveis. Esse decreto teria sido complementado por instruções normativas das autoridades sanitárias, instruções essas mutáveis e "sem qualquer intervenção dos representantes da cidadania congregados no Parlamento" (p. 46), outro ponto de crítica
para Lewandowski.

O ministro aponta outros problemas referentes à constitucionalidade do artigo $5^{\circ}$ da Lei de Biossegurança: "quando examinado sob 
o prisma do princípio da isonomia, estampado no art. $5^{\circ}$, II, da Carta Magna, o qual se arrima no postulado da dignidade da pessoa humana e tem como uma de suas vertentes o axioma da não-discriminação" (p. 47). Lewandowski acusa de discriminação a permissão de destruir embriões a partir de três anos de congelamento:

O discrímem empregado pelo legislador, para permitir a destruição de embriões a partir dos três anos de congelamento afigura-se infundado, sem sentido e destituído de justificativa razoável, pois não há qualquer explicação lógica para conferir-se tratamento diferenciado aos embriões tendo em conta apenas os distintos estágios de criopreservação em que se encontram. (p. 48)

Coerentemente, os três ministros que acataram a tese da ADI 3.510 tratam dos embriões restantes de reprodução assistida como dotados de personalidade e detentores do direito à vida, bem como de serem protegidos da discriminação.

As referências a dados biológicos se reduziram no debate pelos juízes do STF em contraste com a tônica da audiência pública dos cientistas. Quem argumenta usa termos fortes, inclusive a proteção do genoma humano como patrimônio e a proibição de discriminação com base em características genéticas. Ministros com posições opostas no tocante ao uso de embriões para pesquisa evocaram a proteção do genoma humano como patrimônio, um dado da genética construído como sagrado.

\section{A audiência pública da ADPF 54: antecipação de parto de anencéfalo}

A Arguição de Descumprimento de Preceito Fundamental n. 54 (ADPF 54) foi proposta ao Supremo Tribunal Federal pela Confederação Nacional de Trabalhadores da Saúde. AADPF 54 quer assegurar às gestantes de feto anencefálico o direito de se submeterem à antecipação terapêutica de parto, e garantir aos médicos o direito de realizar 
esse procedimento, uma vez atestada essa anomalia incompatível com a vida, sem necessidade de autorização prévia judicial. O diagnóstico de anencefalia deve ser confirmado por um segundo exame antes da intervenção conforme essa proposta (Fernandes, 2007).

A anencefalia decorre de uma falha no desenvolvimento do embrião quando não se fecha o tudo neural. O feto que venha a se desenvolver não apresenta os hemisférios cerebrais, e a parte remanescente do encéfalo fica exposta, sem a cobertura de ossos ou pele. São conhecidos vulgarmente como bebês sem cérebro. Muitas vezes a gestação não chega a termo, e quando isso ocorre, o bebê na maioria das vezes nasce morto ou tem sobrevida inferior a 24 horas (Fernandes, 2007).

A petição inicial da ADPF 54 diferencia antecipação terapêtica de parto de feto anencefálico de aborto, argumenta a partir da inviabilidade do feto para a vida extrauterina. Com respeito ao mérito, ou seja, os preceitos fundamentais violados, a arguição volta-se para o estado da gestante, cuja situação seria análoga à tortura. A mulher teria violada a sua dignidade de pessoa humana ao ser diagnosticada e impedida de escolher se quer manter a gestação até o final. Outros preceitos violados seriam a autonomia da vontade e o direito à saúde, uma vez que essa gestação implica riscos.

O relator da ADPF 54, ministro Marco Aurélio Mello, em 2004, deferiu medida liminar reconhecendo o direito da gestante à antecipação terapêutica de parto de anencéfalo em $1^{\circ}$ de julho de 2004 , medida que foi revogada pelo plenário do Supremo em 20 de outubro do mesmo ano (Fernandes, 2007). O caso aguarda julgamento. Atribuiu-se a demora do relator para convocar a audiência pública à postura de aguardar a decisão final do STF sobre a ADI 3.510.

A audiência pública ocorreu em quatro sessões: na primeira, em 26 de agosto de 2008, estiveram representantes de movimentos religiosos (CNBB, Associação Nacional Pró-Vida e Pró-Família, Associação Médico-Espírita do Brasil, Católicas pelo Direito de 
Decidir, IURD). Na segunda sessão (em 28/08) houve uma maioria de representantes de associações científicas, mas também esteve presente o deputado Luiz Bassuma, presidente da Frente Parlamentar em Defesa da Vida, e a professora doutora Lenise Aparecida Martins Garcia, presidente do Movimento Nacional da Cidadania em Defesa da Vida - Contra o Aborto. Na terceira (4/09) e quarta sessões (16/09) estiveram presentes, na maioria, representantes da sociedade civil, com destaque para o Ministro da Saúde, José Gomes Temporão, na terceira sessão, e da Ministra da Secretaria Especial de Políticas para as Mulheres, Nilcéa Freire, na quarta sessão. A análise dos depoimentos baseia-se na transcrição da audiência pública, dividida conforme os dias das sessões. ${ }^{3}$

Dos 27 expositores, 11 tinham posições pró-vida, contrárias à antecipação de parto de anencéfalo proposta pela ADPF 54, e 16 assumiram posições pró-escolha. Houve poucas menções diretas a aspectos referentes à genética (genes, cromossomas ou DNA) nas exposições.

Na primeira sessão (26/08), o representante da CNBB, padre Luiz Antônio Bento (Assessor Nacional da Comissão Vida e Família e Comissão de Bioética da CNBB), contestou a tese da ADPF 54 argumentando pela ausência de morte cerebral e pela presença de genoma humano no feto: "como o feto tem o genoma humano, todos os dados genéticos estão presentes na vida desse indivíduo, mas, como o feto pode nascer vivo, mas, como a criança não está em morte encefálica, a premissa da ADPF não tem embasamento" $(26 / 08$, p. 6). O representante da CNBB usa os argumentos mais repetidos com respeito ao estatuto do embrião de laboratório: a presença de DNA humano individual e a definição do termo da vida como a morte encefálica.

O médico e professor Rodolfo Acatauassú Nunes é presidente da Associação Nacional Pró-Vida e Pró-Família e esteve entre os exposi-

3 Agradeço a Debora Diniz e à ONG Anis - Instituto de Bioética, Direitos Humanos e Gênero, por terem me facilitado o acesso à transcrição das quatro sessões da audiência. 
tores na audiência pública da ADI 3.510. Como medida preventiva e de investigação, ele levanta os problemas relacionados ao ácido fólico e sua associação com polimorfismo genético, que pode resultar em anencefalia: "avaliação de polimorfismo genético nas crianças com anencefalia e sua relação com os passos metabólicos do ácido fólico e à verificação do efeito da fortificação do ácido fólico nas formas clínicas dos defeitos de tubos neurais, em especial da anencefalia" (26/08, p. 17). Ele argumenta, a partir de dados filogenéticos, isto é, relativos ao desenvolvimento das espécies animais, que deve existir um grau de consciência primitiva e capacidade de vida relacional
no anencéfalo:

Por uma lógica filogenética desse núcleo da consciência estar situado nas partes mais inferiores, sendo o encéfalo a córtex que enriquece esse "núcleo básico", então não se pode aquilatar com toda certeza o grau de relação dela com a parte mais complexa do mundo exterior, que possivelmente não exista. Mas existe um certo grau de consciência primitiva. $(26 / 08$, p. 19)

A impossibilidade de avaliar com certeza a inexistência de consciência no anencéfalo (um dos pontos que definem a morte encefálica, cf. Penna, 2005), característica que resultaria em impossibilidade de vida relacional, seria o argumento para rejeitar a antecipação de parto proposta pela ADPF 54.

Outra exposição que invoca referentes sobre genes e anencefalia, na sessão com representantes das religiões, parte da médica Irvênia Luíza de Santis Prada (Associação Médico-Espírita do Brasil). Ela cita o biólogo Rupert Sheldrake: "Os genes não dispõem de programas para morfogênese, ou seja, para desenvolvimento das formas ou órgãos que exercem funções biológicas. Em organismos vivos, essa morfogênese é orientada por campos morfogenéticos extrafísicos não-locais" (26/08, p. 27). Ela defende que os genes não dispõem de programas para desenvolvimento dos órgãos que exerçam funções biológicas porque haveria uma dimensão extrafísica: "Essa dimen- 
são extrafísica de atuação no local é chamada [...] de "consciência"" (26/08, p. 27). A consciência seria uma dimensão extrafísica exterior ao córtex: "O indispensável substrato da consciência localiza-se fora do córtex cerebral" (26/08, p. 28). Argumentando de modo semelhante ao Dr. Rodolfo Acatauassú Nunes, ela afirma que a consciência não estaria no córtex, estrutura ausente nos anencéfalos. Para o propósito deste texto, porém, salienta-se o fato de essa expositora afastar a importância dos genes para a morfogênese.

Nesse dia, a última intervenção que relaciona genes no debate sobre aborto de anencéfalo é feita pela médica Marlene Rossi Severino Nobre, presidente da Associação Médico-Espírita Internacional e da Associação Médico-Espírita do Brasil. Citando o livro A caixa preta de Darwin, ela afirma que a célula foi planejada por uma inteligência superior. Essa inteligência superior teria "outorgado" a vida, para tanto a médica cita evidências: "se vamos falar de motivos pelos quais nós encaixamos na vida outorgada, nós temos as ligações covalentes, as ligações gene/proteína, a estruturação topológica de carga, e assim por diante" (26/08, p. 30). A teoria apresentada pela médica espírita é conhecida como teoria do design inteligente. As ligações gene/proteína seriam indícios que provam a concessão da vida por um ser superior, por isso a impossibilidade de fazer cessar a vida com a antecipação do parto de anencéfalo.

Na segunda sessão de 28/08, composta principalmente por representantes de associações científicas, o médico Heverton Neves Pettersen representante da Sociedade Brasileira de Medicina Fetal associa a origem da anencefalia a componentes genéticos: "Por que ocorre esse defeito de fechamento? A questão técnica - se é devido à parte genética ou alimentar - ainda não foi completamente definida" (28/08, p. 14).

Nessa mesma sessão, falou o deputado federal Luiz Bassuma, presidente da Frente Parlamentar em Defesa da Vida - Contra o Aborto, e espírita kardecista. O deputado argumenta pelo direito 
inviolável à vida previsto na Constituição para rejeitar a tese da ADPF 54, usando o argumento da formação do DNA individual na fecundação como marco de início da vida:

Então, no início da formação, porque, hoje, se conhece a respeito desde o momento da fusão do espermatozóide ao óvulo, aquele momento mágico, $[\ldots]$ a mulher $[\ldots]$ passa a ter uma única célula [...] que não é nem o DNA do homem que forneceu o espermatozóide e nem o DNA da mulher que forneceu o óvulo, é o DNA de um novo ser humano que todos os sete bilhões de seres que vivem na terra, hoje, têm o seu DNA específico e nunca se repetiu essa coisa maravilhosa. [...] A vida tem esse princípio exato. $(28 / 08$, p. 29$)$

No argumento do deputado, aparece o DNA como essência da vida e da identidade do ser humano.

Por fim, ainda nessa sessão, o médico geneticista Salmo Raskin representante da Sociedade Brasileira de Genética Médica explica que, na maioria dos casos a origem da anencefalia é multifatorial, com associação de componente genético e componente ambiental. Com respeito ao aspecto genético: "A anencefalia pode estar associada a problemas cromossômicos, como a trissomia do cromossomo 18, 13, triploidias e alterações estruturais. Ela pode estar associada a mais de vinte síndromes genéticas" $(28 / 08$, p. 33-34). Ele salienta a dificuldade em obter órgãos de anencéfalo para transplante, porque estão já estão lesionados pela hipóxia (falta de oxigênio). Por fim, Raskin apresenta o papel do médico geneticista: "É o aconselhamento genético. (...) É um processo de comunicação que lida com os problemas associados à ocorrência ou à possibilidade de ocorrência de um distúrbio genético em uma família" (28/08, p. 35), pois existem riscos desse distúrbio se repetir. No depoimento desse médico, a referência a genética diz respeito exclusivamente ao aspecto clínico e à possibilidade de transmissão hereditária. 
Na terceira sessão da audiência pública (4/09), houve o depoimento do ministro da saúde José Gomes Temporão. Temporão informou as políticas do ministério da saúde acerca dessas doenças, em particular o pré-natal, e comentou sobre a relação entre anencefalia e genética: "para prevenção de distúrbios de fechamento do tubo neural o Ministério da Saúde promove ações eficazes, como a adição de ácido fólico a alimentos da cesta básica. No entanto, mais da metade dos casos de anencefalia apresenta outras causas, que podem ser genéticas, ambientais ou congênitas" (4/09, p. 5).

Nessa mesma sessão, falou Claudia Werneck da ONG Escola de Gente, que se ocupa da inclusão social das pessoas portadoras de deficiência física. Essa ONG se coloca contra o aborto eugênico para impedir o nascimento de pessoas deficientes, e por isso participou de encontros sobre antecipação terapêutica de parto:

Nosso objetivo foi colaborar para que não houvesse o risco de que síndromes genéticas e congênitas, que geram múltiplas malformações consideradas graves [...] fossem incluídas na mesma categoria de incompatibilidade com a vida, a partir da qual se discute, hoje, a antecipação terapêutica do parto. (4/09 p. 13)

Ela não considera a anencefalia uma deficiência física, pois na primeira não há expectativa de vida extrauterina. Nesse sentido, sua posição se confrontou com a de vários expositores pró-vida que qualificavam a anencefalia de deficiência.

Ainda nesse dia, a Dra. Ieda Therezinha do Nascimento Verreschi, médica especialista em endocrinologia, representando a Associação para o Desenvolvimento da Família, abordou fatores epigenéticos - isto é, a ação do meio ambiente sobre o funcionamento genético - que levam à formação de fetos anencefálicos: "O outro fator é a questão do controle do ácido fólico. Ele é essencial para a síntese dos precursores, que fazem a síntese e metilação do DNA" (4/09, p. 25). Ela foi mais uma a lembrar da importância do ácido fólico na prevenção da anencefalia por conta de seu papel na síntese de precur- 
sores do DNA. Embora essa expositora tivesse orientação contrária à tese da ADPF 54, sua referência ao DNA foi clínica, desligada da identidade do feto.

A última referência à genética, nessa sessão, não veio de um especialista, mas do marido de uma gestante de anencéfalo, o genitor desse feto, convidado a falar sobre sua experiência. Ailton Maranhão de Almeida conta da perplexidade diante dessa "tragédia" (sic) e da expectativa de um trauma maior se a esposa "optasse em ficar com a criança". Ele se perguntava pela origem da doença: "será que o defeito está no marido? Será que está na mulher? Será que o defeito é genético? Será que o defeito é no sangue?” (4/09, p. 43). A menção diz respeito à origem da doença e não à identidade do feto.

Na última sessão da audiência, em 16/09, não houve referência explícita a questões genéticas no que tange à anencefalia ou à identidade de fetos.

Considerando as referências à genética que surgem no material analisado da ADPF 54, elas aparecem de forma mais esparsa do que no material da ADI 3.510. São de três tipos basicamente: a maior parte vai abordar genética e referentes correlatos (genes, DNA, cromossomas) com respeito à origem da anencefalia. As diversas referências ao ácido fólico como fator de prevenção vão nesse sentido, bem como a comparação com outras síndromes genéticas, incompatíveis com a vida ou não. O segundo tipo, muito mais reduzido, repete o argumento da fecundação como início da vida e surgimento de um novo indivíduo original por conta de sua constituição genética. O DNA, ou genoma, surge como essência do indivíduo. Apenas dois expositores recorreram a esse tópico, não por acaso um dos representantes da CNBB e o deputado Luiz Bassuma que, além de presidente da Frente Parlamentar em Defesa da Vida - Contra o Aborto, é espírita kardecista. Esse argumento é constantemente invocado por adeptos desses grupos religiosos, porém foi usado por apenas dois expositores dentre os onze de orientação pró-vida que questionaram a ADPF 
54, enquanto foi usado por sete dos onze especialistas pró-vida na audiência pública da ADI 3.510. O terceiro tipo é o mais inusitado e vem das duas representantes da Associação Médico-Espírita do Brasil: nessas exposições os genes são apresentados de forma secundária a elementos do plano espiritual, quando se coloca que a consciência está em uma dimensão extrafísica, ou se evoca a teoria do design inteligente para afirmar que a vida foi outorgada por uma inteligência superior, usando a evidência das ligações gene-proteína. Nos dois últimos tipos, a genética aparece como um dado de reforço a um argumento metafísico anterior sobre a constituição essencial do humano ou sua criação por seres superiores, e menos como ciência da hereditariedade. Na ADPF 54, o ponto-chave para a definição da humanidade do feto era a presença ou não de consciência, um ponto mais associado ao cérebro que ao DNA.

\section{Conclusão}

Quando se compara o material analisado no processo da ADI 3.510 , desde a petição inicial, a audiência com os cientistas e o julgamento no Supremo, com o material da petição e audiência pública da ADPF 54, constatam-se menos referências à genética na última. O que ressalta a diferença de argumentação quando se fala de fetos anencefálicos e de embriões de laboratório é a ênfase nos dados genéticos com respeito aos embriões. No caso da anencefalia, apenas o representante da CNBB e o deputado presidente da Frente Parlamentar em Defesa da Vida - Contra o Aborto evocaram a vida a partir da concepção, quando se forma a constituição genética de um novo indivíduo. Quase todos os outros expositores mencionaram genética e cromossomas para explicar a origem da anencefalia, mas não para assegurar um estatuto de pessoa humana plena. No anencéfalo, há mais elementos caracterizando a forma de pessoa e a capacidade de vida relacional, por isso o dito dado genético perde relevância. Quando o objeto é o embrião extracorporal, os expositores pró-vida 
atribuem a autonomia imediata do embrião à sua constituição genética individual, um programa que permite vida relacional até no sentido de secretar proteínas desde a fecundação.

A consciência como sede da humanidade é o argumento principal no debate sobre a antecipação de parto de anencéfalo, tanto que dois expositores localizaram a sede da consciência em outra parte que não o córtex, ausente nesse caso. Também os favoráveis ao uso de embriões para extração de células-tronco afirmam que o substrato físico da consciência começaria em fase mais avançada. Nessa direção, foi o voto do relator Carlos Ayres Britto, ao dizer que o embrião congelado era algo, mas não alguém.

Os movimentos pró-vida argumentam que a vida se inicia na fecundação, fundamentando o estatuto pleno de pessoa humana na constituição genética específica formada na união dos gametas. Esse argumento remete à ideia de DNA como essência humana, já identificada por Salem em artigo sobre inseminação artificial com doador. Essas técnicas reforçam a genetização do ser humano e das relações familiares. Assim, os genes seriam uma nova metáfora da natureza, corporificando a verdade essencial do ser humano, algo que sobredetermina a sua vontade (Salem, 1995). A referência a um embrião dotado hereditariamente de dons artísticos ou à capacidade de o diagnóstico pré-implantação aferir o coeficiente intelectual exemplifica a noção de destino genético presente no embrião (Strathern, 1992). Com a técnica de identificação de genes, criou-se na imaginação popular a ideia de destino genético para conceitualizar as pessoas: a pessoa marcada por seus genes para desenvolver uma dada potencialidade. Hoje, a busca por origens genéticas visa esclarecer esse destino. As indagações sobre as origens antes dirigidas ao parentesco agora voltam-se para o genoma do indivíduo. Se há um programa genético, elimina-se a ideia do acaso no desenvolvimento pessoal, a essência da individualidade estando aí contida (Strathern, 1992: 177-80). 
Ao argumentar se embriões de laboratório ou fetos anencefálicos teriam o direito à vida, vários marcos biológicos do desenvolvimento são evocados a fim de estabelecer se a condição humana estaria ou não presente. Tal busca de marcos estruturais fixos para a condição de pessoa é própria da cosmologia ocidental (Conklin \& Morgan, 1996), o que mostra o valor da natureza como fundamento da condição de pessoa.

De modo geral, o debate reitera a biologia como base para prescrições de ordem social, aspecto característico da cosmologia ocidental moderna (Laqueur, 1992). Mesmo os que argumentam por um plano extrafísico da consciência remetem a esse referente. Reside aí a importância dos especialistas da biologia em todas as fases de ambos os processos, pois são tomados como especialistas: são porta-vozes da natureza (Latour, 2000). Esse aspecto é parcialmente rompido nos julgamentos, quando outros peritos, agora do Judiciário, entram em cena.

Segundo Salem (1997), a caracterização do embrião como pessoa com base em critérios biológicos oculta relações sociais, particularmente as de parentesco, no caso a relação com a gestante, representando-o em termos do ideal de indivíduo. Isso está explicitado nos exemplos em que o zigoto apresenta capacidade de comunicação através da secreção de proteínas, ou nas provas fisiológicas da capacidade relacional do anencéfalo. Os valores naturalistas na descrição de embriões e fetos como seres humanos essenciais em termos biológicos - conforme se vê em diversas expressões acima, que alegam o caráter de sujeito individual da espécie humana ao zigoto, desde a fecundação até a morte - integram a cosmologia ocidental moderna e são poderosa arma na retórica pró-vida. O debate do aborto é estruturado de forma a opor os direitos de dois ditos indivíduos: o feto e a gestante. Nesse sentido, essa oposição se assemelha ao conceito de cismogênese complementar (Bateson, 1958), pois a atribuição de direitos a um implica a destituição de direitos do outro. 
Vários atores religiosos estão em cena. Estes são os que mais salientam seus dados como científicos a fim de ganhar legitimidade no campo jurídico, o que revela o discurso científico com mais peso no mercado linguístico (cf. Bourdieu, 1996) do que o discurso religioso. Por outro lado, exemplos revelam a sacralização dos dados naturais, como a declaração da Unesco sobre o genoma humano, que propõe a intangibilidade do patrimônio genético humano, e diversas menções espiritualizadas a características de embriões e fetos. Reivindica-se o estatuto de sujeito para tais entes. O relator da ADI 3.510, o ministro Carlos Ayres Britto, já havia observado: “o inviolável é, para o Direito, o que o sagrado é para a religião" (voto, p. 26). No direito, a vida humana deve ser inviolável, portanto sagrada. Noções de vida sagrada no embrião e no feto anencefálico remetem a abordagens de Mauss (2003) e Durkheim (1989) sobre o poder contido em objetos mágicos. Durkheim já havia apontado o indivíduo como o centro da religião moderna, que cultua o ser humano em abstrato nas sociedades ocidentais, hipótese que refletida na afirmação do indivíduo como valor (Dumont, 1992). Se a natureza biológica humana é sacralizada, conforme se depreende na declaração da Unesco do genoma como patrimônio da humanidade, o debate sobre a legalidade da pesquisa com embriões humanos de laboratório e a antecipação de parto de feto anencefálico revelam que esse caráter sagrado advém dos indivíduos humanos.

\section{Referências}

BATESON, G. Naven: a survey of the problems suggested by a composite picture of the culture of a New Guinea tribe drawn from three points of view. Stanford: Stanford University Press, 1958.

BOURDIEU, P. A Economia das Trocas Linguísticas: o que falar quer dizer. São Paulo: Edusp, 1996.

CONKLIN, B. A. \& MORGAN, L. M. Babies bodies and production of personhood in North America and a Native Amazonian society. Ethos, 24: 657-694, 1996. 
DUMONT, L. Ensaios sobre o Individualismo: uma perspectiva antropológica sobre a ideologia moderna. Lisboa: Dom Quixote, 1992.

DURKHEIM, É. La Science Sociale et l'Action. Paris: Presses Universitaires de France, 1970.

DURKHEIM, É. As Formas Elementares de Vida Religiosa. São Paulo: Paulinas, 1989.

FERNANDES, M. C. Interrupção de gravidez de feto anencefálico: uma análise constitucional. In: SARMENTO, D. \& PIOVESAN, F. (Orgs.). Nos Limites da Vida: aborto, clonagem humana, eutanásia sob a perspectiva dos direitos humanos. Rio de Janeiro: Lumen Júris, 2007.

LAQUEUR, T. Making Sex: body and gender from the greeks to freud. Cambridge: Harvard University Press, 1992.

LATOUR, B. Jamais Fomos Modernos: ensaio de antropologia simétrica. São Paulo: Editora 34, 2000.

MAUSS, M. Sociologia e Antropologia. São Paulo: Cosac \& Naify, 2003.

PENNA, M. L. F. Anencefalia e morte cerebral (neurológica). Physis-Revista de Saúde Coletiva, 15: 95-106, 2005.

SALEM, T. O princípio do anonimato na inseminação artificial com doador (IAD). Physis - Revista de Saúde Coletiva, 5: 33-68, 1995.

SALEM, T. As novas tecnologias reprodutivas: o estatuto do embrião e a noção de pessoa. Mana-Estudos de Antropologia Social, 3: 75-94, 1997.

STRATHERN, M. Reproducing the Future: essays on anthropology, kinship and the new reproductive technologies. Manchester: Manchester University Press, 1992.

\section{Fontes:}

BRASIL. Supremo Tribunal Federal. Petição para Ação de Inconstitucionalidade 3510 de 16 de maio de 2005. Procurador-Geral da República Cláudio Fonteles. BRASIL. Supremo Tribunal Federal. Petição para Arguição de Descumprimento de Preceito Fundamental 54 de 16 de junho de 2004. Confederação Nacional dos Trabalhadores na Saúde.

BRASIL. Supremo Tribunal Federal. Transcrição de Audiência Pública de 
Instrução para a Ação Direta de Inconstitucionalidade 3.510, realizada em 20
de abril de 2007. BRASIL. Supremo Tribunal Federal.

rente à Arguição de Descumprimento Transcrição de Audiência Pública referealizada em 26 e 28 de agosto BRASIL. Supremo Tribunal Federal. 4 e 16 de setembro de 2008. tucionalidade $3510 \mathrm{em} 5$ de medal. Votos dos ministros na Ação de InconstiCarlos Britto; Ministra Carmem Peluso; Ministra Ellen Gracie; Ministrinistro Celso de Mello; Ministro Cezar Ministro Joaquim Barbosa; Ministro Ministro Ricardo Lewandowski. 


\section{A “MOleCularizaÇÃo” DO CÂNCER DE PRÓSTATA: REFLEXÕES SOBRE O CHIP DE DNA}

Marko Monteiro Ricardo Z. N. Vêncio

\section{"Molecularizando" o corpo}

Investigações recentes da prática científica, feitas a partir da antropologia, das ciências sociais e dos Estudos Sociais da Ciência e Tecnologia (ESCT), vêm analisando o conceito de "molecularização" da vida e do corpo a partir de uma diversidade de perspectivas (Lynch, 2003; Lynch, 1998; Keating \& Cambrosio, 2004; Shostak, 2005; Sommerlund, 2006; Braun, 2007; Fullwiley, 2007; Rose, 2007a; 2007b). Esses trabalhos começam a delinear uma descrição de uma importante mudança nas formas de classificação científicas: antes baseadas na fisiologia, nomeando e dando sentido ao corpo a partir da sua aparência externa e das suas macroestruturas, essas classificações são cada vez mais baseadas em características moleculares ou genéticas. Este texto ${ }^{1}$ busca ampliar esse debate ao considerar o conceito de representação molecular a partir do exemplo do câncer de próstata.

A partir de uma análise da distinção entre formas fisiológicas e moleculares de representação do câncer de próstata na ciência, nosso objetivo é o de melhor definir o sentido de "molecular" na sua relação com as classificações do câncer. Formas moleculares de represen-

\footnotetext{
Este texto, escrito com base em uma pesquisa financiada pelo Fundo de Amparo à Pesquisa do Estado de São Paulo (Fapesp) realizada entre 2001-2005, é uma versão revisada de artigo previamente publicado em Leonardo Electronic Almanac, v. 16 (4-5): 1-11, 2009.
} 
tação podem ser descritas, para além da sua relação com a biologia molecular (o DNA, o RNA e as proteínas), pelo deslocamento que causam das bases da classificação da fisiologia para a informação, do visual para o numérico e do diagnóstico para a manipulação. O conceito de representação, como é tradicionalmente compreendido, define que algo (por ex., um conceito) substitui ou "representa" outra coisa (por ex., uma parte ou estrutura do corpo humano). Essa definição do conceito não descreve adequadamente as emergentes formas moleculares de definição de doenças, pois, nesse caso, os mesmos conceitos que são usados para "representar" aspectos do corpo se transformam em formas de manipular e interferir nesse mesmo corpo.

A atual bibliografia sobre molecularização analisou as formas complexas a partir das quais as novas tecnologias e formas de classificação que operam na escala molecular vêm impactando as dinâmicas sociais, incluindo: compreensões de saúde e doença (Hedgecoe, 2002; Shaw et al., 2003); o desenvolvimento de novas drogas e tratamentos, ou a chamada "medicina personalizada" (Shostak, 2005); identidades raciais e formas de classificação (Santos \& Maio, 2004; Fullwiley, 2007), e os desafios éticos e políticos que emergem da molecularização da "vida em si" (Rose, 2007b). Recentemente, artistas vêm também explorando o potencial de tecnologias que operam na escala molecular como meio de expressão (Kac, 2007; Monteiro, 2006), sugerindo que tais tecnologias produzem não apenas metáforas a respeito da vida que circulam socialmente, mas configuram novas formas de interação com a natureza que problematizam nossas compreensões tradicionais a respeito dessa relação.

As práticas de construção de novos seres vivos para fins artísticos, como a já bastante debatida coelhinha Alba de Eduardo Kac (Kac, 2003) ou as esculturas semivivas dos artistas australianos Oron Catts e Ionat Zurr (Catts \& Zurr, 2002), são práticas de subversão dos sentidos da tecnologia que, ainda que não diretamente ligados à saúde ou ao corpo diretamente, ajudam a tornar mais clara a importância de se 
discutir a representação de novas formas no contexto atual, marcado pelas possibilidades de manipulação da matéria viva (através das biotecnologias) ou inanimada (pela nanotecnologia). Enquanto alguns autores discutem o fim do conceito de representação (Lynch, 1994), neste capítulo queremos analisá-lo em termos das suas premissas a respeito do que significa descrever o corpo e suas estruturas, e como isso define nossa relação com seu significado e sua materialidade.

Os desafios teóricos relacionados à compreensão das tecnologias ligadas à genética e como estão impactando a sociedade ainda estão sendo esboçados, colocando em xeque inclusive algumas das formas pelas quais nossa visão de mundo "ocidental" opera. Um exemplo importante é a separação entre matéria e significado (Scheper-Hughes \& Lock, 1987) na explicação das práticas de manejo e reconstrução do corpo. Essa perspectiva, ao conceber o corpo como um suporte biológico fixo para representações mentais variáveis, limita o escopo das questões que podemos fazer com relação ao processo de molecularização. O presente texto não busca esboçar todos esses desafios, nem muito menos resolver definitivamente o problema; buscamos, pelo contrário, recolocar algumas questões de forma a redirecionar futuras interpretações de práticas ligadas à molecularização, dentro e fora da prática científica.

Nossas intenções são, assim, bastante modestas: queremos explorar, através de um exemplo bem localizado, no interior de um debate específico a respeito da pesquisa com câncer de próstata, questões mais gerais a respeito da forma pela qual o corpo biológico é "enquadrado" pela tecnologia (Lynch, 2006): uma fisiológica, ou "analógica", e outra molecular, ou "digital". A dualidade entre analógico e digital tal qual utilizada aqui pode gerar certa confusão, na medida em que evoca determinados debates sobre as relações entre corpo e tecnologias digitais que trabalham com a ideia de "desmaterialização" a partir do uso intensivo de informação. Para evitar essa confusão, trabalhamos aqui a partir de um foco no conceito de representação, dando ênfase à materialidade dos corpos em questão. 
A metáfora do DNA como uma molécula informacional aparece em outros debates sobre biotecnologia e genética (Hood et al., 2008, Kay, 2000; Thacker, 2003a), mas nosso objetivo aqui é focar menos na informação, e mais na questão da representação. Desejamos tornar essa aparente dualidade (analógico e digital) menos óbvia e mais problemática, ao menos com relação às formas pelas quais ela tem sido utilizada para descrever a intersecção entre corpos e tecnologias (Hayles, 1999; Waldby, 2000; Dyens, 2001), contextualizando a forma pela qual essa distinção pode ser produtiva para pensar um quadro molecular para a representação.

Outro objetivo é evitar a armadilha colocada por ideias de desmaterialização associadas a um corpo informacional. Tal postura teórica não consegue captar a complexidade dos impactos que a molecularização vem tendo e continuará a ter nas nossas relações com a nossa biologia, nossas identidades e nossas formas de autorrepresentação. Um "corpo digital" evoca ideias de controle irrestrito, uma imagem também usada por alguns cientistas quando descrevem o impacto da genética (Wilmut, Campbell \& Tudge, 2000). Nosso objetivo é discutir como a "matéria" é importante nessas práticas moleculares de representação que fazem mais do que criar e manipular significados, mas operam num nível no qual atos de nomear e classificar servem também para manipular a própria composição biológica dos corpos em questão. Para tanto, o microarray ${ }^{2}$ servirá como ponto de partida para a discussão, sendo o objeto que incorpora os conceitos acima mencionados.

\section{Representações moleculares}

As análises deste capítulo partem de observações etnográficas conduzidas em duas importantes instituições científicas do estado

\footnotetext{
2 Um microarray de DNA, conhecido também como chip de genoma, chip de DNA ou ordenamento de genes, é uma coleção de pontos microscópicos de DNA, geralmente representando genes individuais ordenados sobre uma superfície sólida.
} 
de São Paulo: a Universidade de São Paulo e o Instituto Ludwig de pesquisa sobre o câncer. ${ }^{3}$ A discussão foca, no entanto, principalmente uma análise dos artigos científicos que foram usados no contexto da pesquisa observada, que descrevem o estado da arte naquele momento da pesquisa por um biomarcador molecular para o câncer de próstata, o foco da pesquisa colaborativa sendo desenvolvida entre as instituições mencionadas acima. Esses artigos são originários de diferentes instituições e países, informando não somente os cientistas brasileiros, mas diversos laboratórios ao redor do planeta que trabalham com problemas semelhantes. A molecularização não está, dessa forma, limitada a fronteiras nacionais ou a uma área específica da ciência.

Nosso foco não será, portanto, a descrição etnográfica de como esse grupo específico de cientistas pratica a molecularização da próstata, mas na questão da molecularização em si enquanto um artefato do conhecimento, como uma nova forma de conceituar a natureza. Qual é o significado do enquadramento da biologia tornado possível pela busca por biomarcadores moleculares como parte de um processo mais geral de mudança nas formas de classificação? Quais questões podem ser levantadas a respeito da relação entre classificações científicas e como elas permitem que corpos (ou naturezas) existam de formas específicas (Latour, 1995; Latour \& Woolgar, 1997)?

Analisaremos o microarray na sua relação com a forma pela qual a próstata (e o câncer de próstata) está sendo traduzida para termos moleculares. Essa tradução, mais do que uma mudança na

3 A pesquisa de campo ocorreu entre maio e agosto de 2004. Nesse período, visitas foram feitas ao Instituto de Matemática e Estatística (IME) da USP, onde foi criado um programa de Doutorado em Bioinformática que abrigava diversos projetos nesse campo. No interior da USP, também foram feitas visitas ao Instituto de Química, onde pesquisas importantes na área de câncer de próstata eram conduzidas sob a supervisão do Prof. Sergio Verjovski- Almeida. Entrevistas foram feitas com diversos pesquisadores do Instituto Ludwig de Pesquisa com Câncer e do Hospital de Câncer A. C. Camargo (que na época funcionavam no mesmo prédio, desenvolvendo pesquisas de forma bastante próxima). Nessas instituições, pesquisadores da área médica e da área de bioinformática foram entrevistados. As instituições mencionadas colaboravam, nesse período, com projetos de sequenciamento e pós-genômicos focados na expressão de genes ligados a tumores da próstata. 
modalidade visual ou descritiva, representa um deslocamento de paradigmas na medida em que mudam os elementos representativos e a forma pela qual tais elementos são ligados a projetos de manipulação do corpo. Ainda que se possa argumentar que essa ligação da representação com a manipulação seja talvez típica daquilo que define a ciência moderna (Rabinow, 2000) desde Descartes (Donatelli, 2000; Descartes, [1641]1999) ou Bacon (Bacon, 2000), o nível molecular pode ser analisado em termos da maneira como torna possível essa manipulação de maneiras antes impensadas. Diferentemente de Nikolas Rose e seus debates éticos e filosóficos a respeito da molecularização enquanto uma "política da vida em si" (Rose, 2007b), nosso foco será a relação entre a materialidade do corpo e práticas de representação atualmente desenvolvidas em práticas científicas. A representação em termos moleculares torna-se assim a busca pela reconstrução, minando a oposição entre nomear e intervir (Rheinberger, 2000).

$\mathrm{O}$ argumento baseia-se numa comparação entre o teste de Gleason e os dados dos microarrays, ambos métodos de classificar o câncer de próstata e avaliar as características do tumor. O teste de Gleason, que depende de uma caracterização visual que correlaciona forma e função, é um biomarcador bastante consolidado, tendo sido incorporado às práticas médicas e suas rotinas. O exame de PSA, ${ }^{4}$ também usado como marcador para o câncer de próstata, não conseguiu se estabelecer como método de precisão, sendo utilizado sempre em conjunto com outras formas de diagnóstico (como o exame de toque). O microarray é uma tecnologia emergente que ainda é disputada em termos do seu uso e aplicação (Brown \& Botstein, 1999; Segal et al., 2005), mas é considerada como altamente promissora. Não existem bio-

4 O antígeno prostático específico ou PSA é uma enzima com algumas características de marcador tumoral ideal, sendo utilizado para diagnóstico, monitoramento e controle da evolução do câncer de próstata. 
marcadores moleculares estabelecidos para o câncer de próstata ainda, mas a pesquisa com microarrays tornou-se uma das mais importantes áreas de estudo do câncer atualmente (Segal et al., 2005; Pinkel \& Albertson, 2005).

Microarrays são ao mesmo tempo uma forma de medir a expressão gênica, uma forma de traduzir essa expressão em dados numéricos (compreensíveis por computadores), além de potencialmente mudar drasticamente as nossas formas de classificação e tratamento do câncer e outras doenças. Essa classificação molecular é mais do que simplesmente descritiva: por conta da especificidade da escala molecular na célula, classificações baseadas no DNA tornam possíveis novas formas de interagir e recriar as estruturas descritas (Rajan, 2006; Rheinberger, 2000). Isso sugere a necessidade de reavaliação do sentido da representação na ciência e na arte, na medida em que utilizamos cada vez mais tecnologias moleculares nas nossas práticas de compreensão da biologia, do corpo e da vida.

Os microarrays, no âmbito específico da saúde, permitem a racionalização de desenvolvimentos terapêticos precoces na medida em que permite a definição de "assinaturas" (Keating \& Cambrosio, 2004) ou alvos utilizáveis no diagnóstico (Rajan, 2006). Os chips de DNA podem potencialmente transformar indivíduos em "pacientes em espera" ou "consumidores em espera" (Rajan, 2006): pacientes em espera, pois representações genômicas da vida possuem uma legitimidade adicional enquanto previsões do futuro biológico do indivíduo; e consumidores em espera, pois essas novas condições deixam o indivíduo suscetível a novas formas de tratamento, como os testes de novas drogas, novos tratamentos para doenças etc.

Essa ideia de descrever ao mesmo tempo em que se recria o corpo é um aspecto do que Paul Rabinow chamou de biossocialidade (Rabinow, 1996; 1999). O conceito de Rabinow relaciona-se intimamente com o manejo do risco, ou biopoder (Lash, 1991; 
Foucault, 2007a; 2007b): a vigilância é substituída pelo manejo constante das populações, de acordo com a percepção de predisposições a patologias descritas em termos genéticos. A posse de um ou mais genes associados a uma doença conhecida constitui assim um risco incorporado antes da manifestação de quaisquer sintomas, deslocando nossa percepção da saúde e da doença.

Além disso, Rabinow aponta para a administração do eu a fim de produzir um sujeito eficiente e adaptável. Estamos deixando de lado a vigilância do indivíduo e de grupos sabidamente perigosos e adotando a classificação e o manejo dos fatores de risco que reconstroem indivíduos e grupos de diferentes maneiras, descontextualizando-os da sua experiência social, histórica e corpórea. A molecularização do câncer de próstata, nesse sentido, é uma das tecnologias mais avançadas para operar essa descontextualização, no âmbito específico dessa doença. Ela permite a representação do corpo em termos de conjuntos complexos de dados, que podem ser visualizados e manipulados em diversas modalidades (visual, computacional, biotecnológica). A habilidade de nomear um gene ou grupo de genes enquanto "biomarcadores" do câncer de próstata, assim, opera não somente uma mudança na forma de representação (o câncer classificado em termos genéticos), mas desloca nossa experiência da doença (detecção precoce, manejo constante) e até de nossos corpos. A possibilidade de localizar tais patologias muda a experiência subjetiva do corpo e da doença ali presente, a priori, enquanto potencial inevitável.

\section{Corpo digital, corpo analógico: do teste de Gleason ao mi- croarray}

Algumas das questões colocadas à instrumentalização científica do DNA são: como o corpo é enquadrado pela tecnologia? Como tecnologias específicas criam formas de perceber e relacionar-se com o corpo que são únicas? Como o corpo adapta-se, em toda a sua complexidade, às limitações intrínsecas a cada tecnologia? O corpo 
integra-se totalmente com os coletivos de humanos e máquinas que compõem a ciência contemporânea (Latour, 1994; 2005) ou, pelo contrário, essa complexidade cria problemas para esses sistemas? $\mathrm{O}$ que a atual pesquisa com microarrays tem a ver com nossas representações do corpo?

O DNA tem duas funções básicas, de acordo com o modelo científico mais aceito atualmente: a replicação, que é responsável pela hereditariedade, e a transcrição dos genes, o processo que gera as "mensagens" (Brown \& Botstein, 1999; Duggan et al., 1999; Gopalkrishnan, Kang \& Fisher, 2001; Lacroix et al.; 2002; Mohr et al., 2002). O RNA que resulta da transcrição pode ser RNA mensageiro (mRNA), RNA ribossomal (rRNA) ou RNA de transporte (tRNA). Esses três tipos de RNA juntos são responsáveis pelo processo de tradução que resulta num polipeptídio (uma proteína, ou parte de uma). Esses polipeptídios são partes funcionais e ativas da célula. Nesse modelo tradicional, somente as proteínas são pensadas como parte funcionais da célula, o que tem sido questionado por pesquisas mais recentes, que implicam também o RNA nessas funções (Porkka et al., 2007).

O microarray é uma técnica para a mensuração da expressão gênica de forma comparativa, usando a quantidade de mRNA que foi produzida por cada gene. Dessa forma, a medida é obtida do quão ativo um determinado gene é, dadas as condições celulares/ fisiológicas em que se encontra, na comparação com outra. Ao invés de contar o número de fitas de mRNA, um chip é produzido, e sobre sua superfície são fixadas sequências de DNA para serem testadas. O RNA é extraído durante a circunstância particular que está sob análise (por exemplo, quando determinada droga entra em contato com a célula) e marcado com moléculas fluorescentes, que são então espalhadas na superfície do chip.

Cada sequência de mRNA vai então ligar-se a um lugar específico do chip (uma sequência de DNA relativa a um gene particular), de 
acordo com o princípio de que cadeias de nucleotídeos complementares unem-se de forma estável (o chamado pareamento de Watson-Crick). Após esse processo se completar, o chip é analisado e a luz que emana de cada ponto é mensurada. Através do contraste, tem-se assim uma medida da atividade de cada gene, na comparação com uma situação de controle (por exemplo, a ausência da droga sendo testada).

A importância da pesquisa de microarray relacionada ao câncer tem crescido de forma exponencial, como mostra Mohr et al. (2002). De acordo com os autores, o número de citações na $\mathrm{Me}$ dline contendo as palavras "microarray" e "microarray+câncer" explodiu desde 1998. Esse número vai de 0 a 170 em 1999, 350 em 2000 e 700 em 2001 (Mohr et al., 2002). Aproximadamente $25 \%$ desse total são artigos relacionados com câncer. Esse número não para de crescer: havia mais de 11.300 entradas contendo "microarray+câncer" na Medline até o fim de 2009. Algumas das aplicações mais promissoras dos microarrays são a criação de perfis moleculares para indivíduos, através do que se convencionou chamar de "medicina personalizada". Essas impressões digitais moleculares podem ajudar na compreensão, entre outras coisas, das diferentes reações apresentadas por indivíduos distintos às mesmas drogas e tratamentos, como descreve a recente área da farmacogenômica (Hedgecoe \& Martin, 2003).

Para Mohr et al. (2002), as pesquisas com microarrays podem levar à descoberta de marcadores moleculares para o câncer:

A comparação baseada nos estudos de expressão gênica com microarrays indica uma gama de genes muito ou pouco ativos, que revela uma impressão digital relevante do estado molecular, fornecendo um corpo significativo de candidatos a marcadores moleculares da doença. A análise global das transcrições pode ter, em combinação com o saber a respeito da importância clínica do progresso da doença, aplicações 
poderosas no diagnóstico do câncer e no manejo dos pacientes.

Seu uso do termo "imp

arqueológicas (no sentido fouso digital molecular” sugere ligações tradução do corpo em to foucaultiano) entre o atual processo de lecimento, no século criminal, que também de personalidade. análise das proporções fito a partir da medição do crânio e da era homossexual, "degenorais a fim de determinar se a pessoa tras condições tidas comorada", retardada mental ou possuía oudigitais, descoberta como patológicas. O uso atual de impressões da individualidade bión período, impôs-se como um marcador no entanto, além de magica. Uma impressão digital molecular, todos os outros, permite a especificidade do indivíduo perante características, deslocande potencial manipulação de todas essas do século XIX arqueológica pode ser mais bem compreendida se rays com o teste de Glea contemporânea sobre câncer e microarbaseia-se na análise visual Esse teste, usado ao redor do mundo, patologista, através de um de características morfológicas por um cam agora estabelecer mam microscópio óptico. Pesquisadores busclassificação mais "objetiva" moleculares que permitirão uma genômicos, o que permitiria dos tumores, baseada em elementos tumores durante o tratamento também um ataque mais preciso aos

5

"Microarray-based

genes that reveals a relession comparison indicates a panel of up- or downregulated

large body of candidate molecular mar fingerprint of the cellular state and provides a the clinical importance of disease process, global transe. Combined with knowledge of
ful application in feitas por Marko Monteiro). 
A classificação molecular do câncer: Infelizmente a aparência morfológica do tumor, usada no passado como um marcador da doença, apresenta sérias limitações para a identificação e a classificação do câncer. Dois tumores com uma aparência histológica semelhante podem ter comportamentos clínicos muito diferentes. Essa variabilidade reflete a heterogeneidade molecular do tumor. Como são os distúrbios no programa de transcrição que explicam em grande parte a diversidade biológica do tumor, a construção de perfis de expressão gênica pode ajudar a revelar genes cuja expressão poderia ser considerada ideal para a classificação molecular do câncer. Dentro de cada perfil molecular será relevante individualizar marcadores específicos com valores "taxonômicos" diversos". (Mohr et al., 2002: 3.170) ${ }^{6}$

A busca por marcadores biológicos para o câncer de próstata não é própria do contexto pós-genômico: o teste de PSA já configura um marcador bastante aceito da possibilidade do câncer de próstata. Com o teste de Gleason, um método foi estabelecido para nomear a severidade do tumor de acordo com a malignidade, facilitando o tratamento e o prognóstico.

O teste de Gleason (Gleason, 1966; 1977) é feito a partir da análise visual, feita por um patologista através do microscópio, de fatias de tecido canceroso retiradas da próstata. $O$ teste avalia a capacidade das células cancerígenas de imitar a arquitetura das células normais, especialmente aquelas células que formam as glândulas características desse tecido. A habilidade do tumor de "imitar" o tecido normal é chamada de diferenciação. A experiência mostra que um tumor com

6 "Molecular classification of cancer: Unfortunately, the morphologic appearance of tumor, previously used as one of the cancer markers, presents serious limitations for the identification and classification of cancer. Two tumors with a similar histologic appearance can have very different clinical behavior. This variability reflects the molecular heterogeneity of tumor. Since perturbation in the transcriptional program accounts greatly for the biologic diversity of tumor, gene expression profiling can help to disclose genes whose expression could be considered ideal for molecular classification of cancer. Within each molecular portrait, it will be relevant to individualize specific markers with different "taxonomic" value." 
uma arquitetura altamente diferenciada (ou seja, que imita muito bem o tecido normal) provavelmente agirá como tecido saudável sendo assim menos maligno e agressivo ao organismo. Uma nota de Gleason um significa tecido altamente diferenciado, enquanto uma nota cinco indica pouca diferenciação, portanto maior malignidade.

Enquanto alguns autores (Mohr et al., 2002) demonstram entusiasmo por tais técnicas, outros são bem menos otimistas, levantando diversas questões ao uso generalizado de marcadores moleculares para o diagnóstico e tratamento do câncer. Mesmo dentre aqueles artigos analisados que expressaram uma visão mais positiva houve níveis diferentes de otimismo, denotando um campo ainda indefinido e rico em polêmicas.

Asmann et al. (Assman et al., 2002), por exemplo, argumentam em favor do potencial do gene CRISP-3 (cysteine-rich secretory protein 3) como biomarcador molecular do câncer de próstata. Na sua pesquisa, os autores buscaram identificar, num total de seiscentos genes expressos na próstata, nove que se expressavam diferentemente em tumores. Os resultados obtidos através da análise por microarrays foram comparadas com resultados obtidos via teste de Gleason, tornando possível uma comparação direta de dados obtidos por cada metodologia. Na sua análise, os autores enfatizam a natureza não específica do teste de PSA, além da necessidade de encontrar formas de classificação que tornassem possível formas mais precisas de diagnóstico e tratamento. O artigo compara de forma explícita ambas as formas de classificação do câncer, argumentando em favor de classificações fundamentadas em dados como mais objetivas e específicas do que aquelas obtidas via análise patológica.

Apesar da intensa busca por biomarcadores para o câncer de próstata, experimentos até o momento não mostram resultados conclusivos, para além de modelos estatísticos que sugerem um gene ou grupo de genes como biomarcador em potencial. Singh et al. (Singh et al., 2002) são mais cuidadosos, sugerindo um grupo de genes como 
potencialmente correlacionados com o câncer de próstata (eles não citam a pesquisa com o CRISP-3). Para esses autores, a ausência de especificidade e certeza nos resultados que emergem de pesquisas com expressão gênica não permite uma substituição completa de exames histológicos como o Gleason. Ao mesmo tempo, os autores sugerem o uso combinado de diferentes métodos para ampliar a certeza no diagnóstico:

Nossa análise revelou diferenças globais de expressão gênica significativas o bastante para tornar possível a diferenciação de tecidos normais dos tumorais, tanto nos conjuntos de treino quanto nos de validação. Ainda que o nível de certeza $(82 \%$ $92 \%$ ) não seja satisfatório para possibilitar uma substituição do exame histológico, tais marcadores moleculares podem vir a ser coadjuvantes úteis para o diagnóstico morfológico. Além disso, enquanto alguns genes que são expressos diferentemente em tecidos normais e tumorais têm sido correlacionados com o resultado em grandes conjuntos de dados [...], nos nossos dados tais genes não estavam altamente correlacionados com o resultado. (Singh et al., 2002: 206) $)^{7}$

Outro artigo crítico com relação às possibilidades de modelagem de processos biológicos (Vilar, Guet \& Leibler, 2003) sugere que o presente interesse em modelos numéricos para processos celulares deriva de uma renovação da tecnologia e uma nova onda de dados empíricos brutos (como aqueles derivados do Projeto Genoma Humano), mas sua capacidade de efetivamente explicar esses processos é limitada. De acordo com o artigo, o uso de modelos tem sido bem-

7 "Our analysis revealed global gene expression differences that were sufficiently robust to distinguish tumor from normal in both training and validation sets. While the level of accuracy $(86 \%-92 \%)$ is not sufficient to replace histological examination, these molecular markers may be useful adjuncts to morphology-based diagnostics. In addition, while certain genes differentially expressed between normal and tumor prostate specimens in microarray experiments have been correlated with outcome in large data sets (...), in our data such differentially expressed genes were not highly correlated with outcome." 
-sucedido na física e na engenharia, mas a enorme complexidade de processos biológicos e a falta de dados empíricos suficientes impõem limites a um sucesso semelhante nas ciências da vida. Os autores afirmam que esse tipo de modelagem é necessariamente limitado, fazendo referência à crença atual de que as interações entre os componentes moleculares podem ser compreendidas com modelos matemáticos ou simulações computacionais, chegando à possibilidade de uma possível reprodução:

Por um lado, a célula não é um reator coerentemente organizado. Ela é uma estrutura altamente heterogênea e compartimentalizada, na qual fenômenos como agrupamentos moleculares ou canalizações estão presentes [...], e na qual a natureza discreta dos componentes moleculares não pode ser ignorada [...]. Por outro lado, são tão poucos os detalhes conhecidos sobre os reais processos que ocorrem in vivo que se torna muito difícil avançar sem um grande número de pressuposições, muitas vezes arbitrárias, a respeito da natureza das não-linearidades e dos valores dos parâmetros que governam as reações. Entender essas limitações, buscando maneiras de superá-las, tornar-se-á cada vez mais importante, a fim de integrar de forma definitiva a modelagem como parte da biologia experimental. (Vilar, Guet \& Leibler, 2003: 471) ${ }^{8}$

O debate especializado a respeito da modelagem computacional de processos biológicos pode ser caracterizado como um gradiente contendo otimistas e pessimistas, além de todo tipo de atitude intermediária. $\mathrm{O}$ debate a respeito da possibilidade de modelagem de processos biológicos, e de como melhor utilizar as ferramentas de

8 "On the one hand, the cell is not a well-stirred reactor. It is a highly heterogeneous and compartmentalized structure, in which phenomena like molecular crowding or channeling are present (...), and in which the discrete nature of the molecular components cannot be neglected (...). On the other hand, so few details about the actual in vivo processes are known that it is very difficult to proceed without numerous, and often arbitrary, assumptions about the nature of the nonlinearities and the values of the parameters governing the reactions. Understanding these limitations, and ways to overcome them, will become increasingly important in order to fully integrate modeling into experimental biology." 
modelagem existentes, é uma característica do discurso científico desde sua emergência moderna (Cassirer, 2000; Chene, 2001). A matematização das nossas representações da natureza e do corpo remontam aos autômatos hidráulicos das cortes europeias do século XVII, se formos pensar numa história da explicação científica e modelagem do corpo e de seu funcionamento interno (Channel, 1991).

Mais recentemente, a emergência da biologia molecular como explicação dominante da vida e da biologia (Yoxen, 1982; Kay, 2000) estabeleceu o DNA como a base material para a hereditariedade. Recentemente, muito tem sido escrito por acadêmicos e jornalistas sobre como o Projeto Genoma Humano e outros grandes projetos científicos têm mudado nossas concepções a respeito do significado da vida (Keller, 1995; Doyle, 1997; Palladino, 2003). No entanto, analisar o gene ou "o livro da vida" como uma metáfora, discutindo os diversos significados da vida biológica, não leva em conta o aspecto principal e mais característico das representações moleculares: a de permitir a superação da dualidade entre nomeação e manipulação do corpo através das biotecnologias. A materialidade do corpo se transforma em meio de expressão, ou "biomeio" (biomedia) (Thacker, 2003a; 2003b) de formas não captadas pelas teorias mais correntes sobre genética e biotecnologia.

Pesquisas atuais sobre corpo e ciência indicam que o ímpeto de modelar está ligado à recriação do corpo de maneiras particulares que precisam ser criticamente exploradas pelos estudos sociais da ciência. A ideia de "reescrever" o corpo de forma autoral (Steinberg, 1997) é útil para compreender o que está em jogo no estudo etnográfico de práticas de representação molecular: mais do que o estudo de visões de mundo ou significados da biologia, o que está crescentemente em pauta são as formas pelas quais nossos corpos serão acessados, mantidos, regulados, curados, compreendidos, conhecidos e experimentados ${ }^{9}$ materialmente.

9 Tanto no sentido de experimento (as formas pelas quais o corpo se torna objeto de estudo e experiências científicas) quanto no sentido experiencial, na forma de como experimentamos nosso ser incorporado no mundo. 


\section{Conclusão: confundindo modelos e corpos}

O microarray é a materialização de um projeto emergente de mudança nas representações da próstata, de formas fisiológicas para formas informacionais. Ainda que tais representações matematizadas estejam fundamentadas em projetos maiores para a elaboração de classificações do corpo a partir dos mesmos elementos que permitem o seu controle e manipulação, a natureza contestada desse campo sugere dificuldades inerentes à possibilidade de uma completa instrumentalização da biologia de seres vivos associada às novas representações moleculares. Tais dificuldades sugerem um campo de possibilidades para estudiosos das ciências sociais e dos ESCT que permanece pouco explorado, especialmente no Brasil.

Assim como outras biotecnologias (clonagem, terapia gênica, pesquisas com células-tronco, organismos transgênicos, entre outras), dados de microarrays têm sido comprovadamente inexatos e cheios de "ruídos", na medida em que a pesquisa busca estabelecê-los como uma forma de elaborar classificações objetivas de fenômenos baseados na genética. Esses ruídos, presentes nas tentativas de reduzir o corpo a um substrato informacional, não têm sido adequadamente levados em consideração por análises dos processos sociais de reconstrução das representações do corpo. Tais processos estão também, em muitos casos, intimamente ligados a projetos de reconstrução da materialidade do corpo, ainda que não completamente livre de problemas, como talvez se desejaria que fossem. Práticas externas aos laboratórios, como a implementação clínica de classificações moleculares de doenças (Shaw et al., 2003), representam um campo de pesquisa em potencial para detectar como as tendências aqui discutidas estão se materializando na sociedade em geral.

A busca por biomarcadores moleculares para o câncer de próstata se contextualiza no desejo de estabelecer uma ferramenta para clas- 
sificar o câncer numa forma drasticamente diferente da tradicional, uma maneira de abandonar a suposta subjetividade do olho humano e abraçar a "objetividade mecânica" (Daston \& Galison, 1990) incorporadas nos testes de DNA e nos (potenciais) biomarcadores. Estudos sugerem que essa tradução do corpo para termos moleculares está ocorrendo em outros campos, de forma igualmente conflituosa (Parry \& Gere, 2006; Shostak, 2004).

Outra maneira de interpretar essa questão é através da análise que faz Michel Foucault das formas de classificação do conhecimento na modernidade (Foucault, 1994). Segundo ele, a "epistemé" que fundamenta a epistemologia científica clássica é aquela da "máthêsis", ou da busca pela medida e pela ordem. Diferentemente de outros períodos, nos quais o saber sobre a natureza era construído principalmente por listas de todas as coisas conhecidas, a partir do século XVII, com a emergência da ciência moderna, tornou-se imperativo organizar, buscar conexões e classificar, a fim de ordenar todo o conhecimento coletado. Nesse sentido, a matemática seria a linguagem universal da "objetividade", permitindo a descrição das inter-relações entre os objetos naturais (Cassirer, 2000).

Assim, a epistemé da ciência clássica, de acordo com essa interpretação, motivou e deu sentido à construção de modelos, matemáticos ou não, que poderiam, em teoria, "descrever" a verdade de toda a natureza de uma forma "analógica". A linguagem (da ciência) não se confundia com a materialidade (da natureza), e a verdade nada mais seria do que uma representação conceitual da natureza, derivada do método científico. Atualmente, essa distância entre conceito e realidade parece estar diminuindo, e daí o nosso uso do termo "digital" para descrever essa nova realidade. A descrição do corpo, por exemplo, em termos linguísticos, através do uso da genética, não fornece simplesmente uma representação teórica da verdade do corpo, mas produz também uma série de ferramentas com as quais se pode manipular e mudar a realidade material que tais conceitos buscam explicar. 
Assim como a informação digital, que permite a manipulabilidade e a capacidade de interpelação de quaisquer dos elementos ${ }^{100}$ que compõem um conjunto (Kittler, 2001), além da atualização dessa informação de múltiplas maneiras (como som, imagem, formas $3 \mathrm{D}$, etc.), a tradução do corpo para termos informacionais se fundamenta na busca de abrir possibilidades de manipulação do corpo e seus processos. A descrição da informação genética e suas relações com o funcionamento do corpo é parte de um projeto maior de construir técnicas de intervenção, correção e melhoramento desse mesmo corpo, que precisam ser criticamente avaliadas e compreendidas.

Tais afirmativas devem ser contextualizadas, primeiramente, em termos de onde são produzidas e a quais necessidades elas servem. $\mathrm{O}$ processo de tradução de classificações oriundas da patologia (como o teste de Gleason) para categorias moleculares e informacionais testa os limites impostos pelo corpo material e sua complexidade. Tais limites deverão interferir ainda mais no desenvolvimento futuro de tecnologias associadas a essas representações, o que deve ser objeto de maiores investigações etnográficas no futuro.

A complexidade do nosso corpo biológico, confrontada com nossa vontade de manipulá-la, é mais bem compreendida quando interpretamos as práticas de representação moleculares como parte de uma história do corpo enquanto meio de expressão em geral, especialmente como meio para a arte (Kemp \& Wallace, 2000; Warr \& Jones, 2000). Em muitos trabalhos do que é hoje conhecido como "body art", a materialidade do corpo é destacada como contraponto ao nosso tratamento dela como maleável. Fluidos corporais (sangue, urina), a relação inextricável entre o material e o emocional (a dor de cortar a carne), a fragilidade de nossa constituição incorporada (como mostram as performances de autoflagelo de Bob Flanagan) são todos elementos que emergem da experimentação com o corpo enquanto meio (Ahmed \&

10 Como os pixels de uma imagem digital. 
Stacey, 2001; Wegenstein, 2004). Alguns experimentos mais recentes com vida artificial e arte também demonstram as limitações estéticas das tentativas de criar, no âmbito virtual, uma reprodução completa da realidade (Brown, Aleksander \& Mackenzie, 2001), levantando questões a respeito de como o tema do controle sobre a vida e a biologia não pode ser simplesmente ignorado em favor de discursos que glorificam o controle tecnológico sobre o corpo.

Experimentações atuais com tecnologias moleculares como ferramentas para tornar a biologia um meio expressivo podem ser vistas como mais um capítulo na história do corpo como meio de expressão artística, levantando questões sobre como existiremos num mundo onde novas formas de vida são mais uma das possibilidades que teremos de nos expressar artisticamente (Tomasula, 2002). Ao discutir Alba, o seu coelho fluorescente, $\mathrm{o}$ artista brasileiro radicado em Chicago Eduardo Kac (um dos principais nomes desse novo tipo de arte) torna explícita sua preocupação com as formas pelas quais essas novas formas de vida serão aceitas no nosso mundo, como cuidaremos delas, como interagiremos com elas de forma ética (Kac, 2003).

O tema da subversão de técnicas científicas para fins estéticos, um aspecto crucial do Projeto de Cultura de Tecidos e Arte (Tissue Culture and Art Project) (Catts \& Zurr, 2002), pode também ser interpretado como uma tentativa performática de interagir com o establishment biotecnológico, tornando explícitos significados que permanecem invisíveis nas suas mais tradicionais formas de expressão (por exemplo, a criação de milho ou soja transgênica). As "esculturas semivivas" dos artistas australianos Catts e Zurr podem ser interpretadas, para além dos objetos semivivos que produzem, como performances de criação de novos seres vivos que, por conta da sua condição de ser experimentos estéticos, revelam alguns sentidos instrumentalizantes implicados nas práticas laboratoriais.

O microarray é assim, neste texto, uma maneira de iniciar o debate sobre as representações científicas atuais da matéria 
corpórea, seus significados e seus efeitos. A representação é uma questão em si mesma somente na arte e na ciência (Lynch \& Woolgar, 1990), e a especificidade das representações científicas tem sido definida como a sua suposta capacidade de descrever o funcionamento interno de um objeto, tornando-o passível de manipulação ativa dos seus princípios. Enquanto esse tema tem sido debatido na literatura dos ESCT em termos de culturas visuais da ciência (Lynch \& Woolgar, 1990; Pauwels, 2006), é só recentemente que uma discussão sobre a matéria corporal como representação se torna mais relevante.

Esse é o objetivo maior deste trabalho: oferecer a ideia de representações moleculares como um esboço teórico dessa virada ontológica envolvendo corpos, tecnologias e "representações". A necessidade de pensar para além do visual, ou da separação entre significados e matéria, não advém de razões teóricas apenas, mas emerge do fato de que "híbridos" (Latour, 1994) e "ciborgues" (Silva, 2000) são crescentemente parte de como interagimos com nosso mundo e entre nós.

O microarray é, portanto, mais do que um "móvel imutável" ou uma "inscrição" (Latour, 1990), termos de Bruno Latour para descrever representações científicas: ele de fato faz uma ponte entre os âmbitos da descrição científica e a manipulação da matéria (Keller, 2000), uma ponte que tende a se tornar mais ampla e mais facilmente trafegável no futuro próximo. Para além dos desafios intelectuais e epistemológicos inerentes a essa discussão, o que importa é definir com maior precisão os processos através dos quais nossos mundos e corpos, no presente e no futuro, estão sendo ativamente (re)construídos. Tais práticas não são neutras, como quaisquer outras práticas sociais também não o são. Por conta disso, uma maior compreensão das maneiras pelas quais elas ocorrem possibilitará um debate público mais produtivo sobre os mundos e os corpos que queremos habitar, agora e no futuro. 


\section{Referências}

AHMED, S. \& STACEY, J. Thinking through the skin. London: Routledge, 2001. ASSMAN, Y. W. et al. Identification of differentially expressed genes in normal and malignant prostate by electronic profiling of expressed sequence tags. Cancer Research, 62: 3.308-3.314, 2002.

BACON, F. The new organon. Cambridge: Cambridge University Press, 2000. BRAUN, B. Biopolitics and the molecularization of life. Cultural Geographies, 14: 6-28, 2007.

BROWN, P. \& BOTSTEIN, D. Exploring the new world of the genome with DNA microarrays. Nature Genetics, 21: 33-37, 1999.

BROWN, R.; ALEKSANDER, I. \& MACKENZIE, J. Biotica: art, emergence and artificial life. London: Royal College of Art, CRD Research, 2001.

CASSIRER, E. The individual and the cosmos in renaissance philosophy. Mineola: Dover, 2000.

CATTS, O. \& ZURR, I. Growing semi-living sculptures: the tissue culture and art project. Leonardo, 35: 365-370, 2002.

CHANNEL, D. The vital machine: a study of technology and organic life. New York: Oxford University Press, 1991.

CHENE, D. D. Spirits and clocks: machine and organism in Descartes. Ithaca: Cornell University Press, 2001.

DASTON, L. \& GALISON, P. The image of objectivity. Representations, 40: 81-128, 1990.

DESCARTES, R. Meditações sobre filosofia primeira [1641]. Campinas: Unicamp, 1999.

DONATELLI, M. Da máquina corpórea ao corpo sensível: a medicina de Descartes, 2000. Tese de Doutorado, São Paulo: Departamento de Filosofia, Universidade de São Paulo.

DOYLE, R. On beyond living: rhetorical transformations of the life sciences. Stanford: Stanford University Press, 1997.

DUGGAN, D. et al. Expression profiling using cDNA microarrays. Nature Genetics, 21: 10-14, 1999.

DYENS, O. Metal and flesh: the evolution of man, technology takes over. Cambridge: MIT Press, 2001. 
FOUCAULT, M. The order of things: an archeology of the human sciences. New York: Vintage Books, 1994.

FOUCAULT, M. História da Sexualidade 1: a vontade de saber. Rio de Janeiro: Graal, 2007a.

FOUCAULT, M. Vigiar e punir: história da violência nas prisões. São Paulo: Vozes, $2007 \mathrm{~b}$.

FULLWILEY, D. The molecularization of race: institutionalizing human difference in pharmacogenetics practice. Science as Culture, 16: 1-30, 2007.

GLEASON, D. Classification of prostatic carcinomas. Cancer Chemotherapy Reports, 50: 125-128, 1966.

GLEASON, D. The veteran's administration cooperative urologic research group: histologic grading and clinical staging of prostatic carcinoma. In: TANNENBAUM, M. (ed.). Urologic pathology: the prostate. Philadelphia: Lea and Febiger, 1977.

GOPALKRISHNAN, R.; KANG, D. \& FISHER, P. Molecular markers and determinants of prostate cancer metastasis. Journal of Cellular Physiology, 189(3): 245-256, 2001.

HAYLES, K. How We became posthuman: virtual bodies in cybernetics, literature, and informatics. Chicago: University of Chicago Press, 1999.

HEDGECOE, A. Reinventing diabetes: classification, division and the geneticization of disease. New Genetics and Society, 21: 7-27, 2002.

HEDGECOE, A. \& MARTIN, P. The drugs don't work: expectations and the shaping of pharmacogenetics. Social Studies of Science, 33: 327-364, 2003. HOOD, L. et al. Systems biology at the Institute for systems biology. Briefings in Functional Genomics and Proteomics, 7: 239-248, 2008.

KAC, E. GFP bunny. Leonardo, 36: 97-102, 2003.

KAC, E. (Ed.). Signs of life: bio art and beyond. Cambridge: MIT Press, 2007. KAY, L. Who wrote the book of life? A history of the genetic code. Stanford: Stanford University Press, 2000.

KEATING, P. \& CAMBROSIO, A. Signs, markers, profiles and signatures: clinical hematology meets the new genetics (1980-2000). New Genetics and Society, 23: 15-45, 2004.

KELLER, E. F. Reconfiguring life: metaphors of twentieth-century biology. 
New York: Columbia University Press, 1995.

. Models of and models for: theory and practice in contemporary biology. Philosophy of Science, 67: S72-S86, 2000.

KEMP, M. \& WALLACE, M. Spectacular bodies: the art and science of the human body from Leonardo to now. Berkeley: University of California Press, 2000. KITTLER, F. Computer graphics: a semi-technical introduction. Grey Room, 2: 30-45, 2001.

LACROIX, M. et al. A low-density DNA microarray for analysis of markers in breast cancers. The International Journal of Biological Markers, 17: 5-23, 2002. LASH, S. Genealogy and the body: Foucault/Deleuze/Nietzsche. In: FEATHERSTONE, M.; HEPWORTH, M. \& TURNER, B. (eds.). The body: social process and cultural theory. London: Sage, 1991.

LATOUR, B. Drawing things together. In: LYNCH, M. \& WOOLGAR, S. (eds.). Representation in scientific practice. Cambridge: MIT Press, 1990.

. Jamais fomos modernos. Rio de Janeiro: Editora 34, 1994.

. The 'pedofil' of Boa Vista: a photo-philosophical montage. Common Knowledge, 4: 144-187, 1995.

. Reassembling the social: an introduction to actor-network theory.

Oxford: Oxford University Press, 2005.

\& WOOLGAR, S. A vida de laboratório: a produção dos fatos científicos. Rio de Janeiro: Relume-Dumará, 1997.

LYNCH, M. Representation is overrated: some critical remarks about the use of the concept of representation in science studies. Configurations, 2: 137-149, 1994.

. Contested identities: science, law and forensic practice. Social Studies of Science, 28: 675-686, 1998.

. God's signature: DNA profiling, the new gold standard in forensic science. Endeavor, 27: 93-97, 2003.

. The production of scientific images: vision and re-vision in the history, philosophy and sociology of science. In: PAUWELS, L. (ed.). Visual cultures of science: rethinking representational practices in knowledge building and science communication. Hanover: Dartmouth College Press, 2006.

.\& WOOLGAR, S. Representation in scientific practice. Cambridge: 
MIT Press, 1990.

MOHR, S. et al. Microarrays as cancer keys: an array of possibilities. Journal of Clinical Oncology, 20: 3.165-3.175, 2002.

MONTEIRO, M. A arte como reinvenção do corpo: explorando práticas reflexivas da matéria. História \& Perspectivas, 35: 175-209, 2006.

PALLADINO, P. Life... On biology, biography, and bio-power in the age of genetic engineering. Configurations, 11: 81-109, 2003.

PARRY, B. \& GERE, C. The flesh made word: banking the body in the age of information. BioSocieties, 1: 41-54, 2006.

PAUWELS, L. (ed.). Visual cultures of science: rethinking representational practices in knowledge building and science communication. Hanover: Dartmouth College Press, 2006.

PINKEL, D. \& ALBERTSON, D. Array comparative genomic hybridization and its applications in cancer. Nature Genetics, 37: S11-S17, 2005.

PORKKA, K. et al. MicroRNA expression profiling in prostate cancer. Cancer Research, 67: 6.130-6.135, 2007.

RABINOW, P. Essays on the anthropology of reason. Princeton: Princeton University Press, 1996.

. French DNA: trouble in purgatory. Chicago: University of Chicago Press, 1999.

. Epochs, presents, events. In: LOCK, M.; YOUNG, A. \& CAMBROSIO, A. (eds.). Living and working with the new medical technologies: intersections of inquiry. Cambridge: Cambridge University Press, 2000.

RAJAN, K. S. Biocapital: the constitution of postgenomic life. Durham: Duke University Press, 2006.

RHEINBERGER, H.-J. Beyond nature and culture: modes of reasoning in the age of molecular biology and medicine. In: LOCK, M.; YOUNG, A. \& CAMBROSIO, A. (eds.). Living and working with the new medical technologies: intersections of inquiry. Cambridge: Cambridge University Press, 2000. ROSE, N. Molecular biopolitics, somatic ethics and the spirit of biocapital. Social Theory and Health, 5: 3-29, 2007a.

. The politics of life itself: biomedicine, power, and subjectivity in the twenty-first century. Princeton: Princeton University Press, $2007 \mathrm{~b}$. 
SANTOS, R. V. \& MAIO, M. C. Race, genomics, identities and politics in contemporary Brazil. Critique of Anthropology, 24: 347-378, 2004.

SCHEPER-HUGHES, N. \& LOCK, M. The mindful body: a prolegomenon to future work in medical anthropology. Medical Anthropology Quarterly, 1: 6-39, 1987.

SEGAL, E. et al. From signatures to models: understanding cancer using microarrays. Nature Genetics, 37: S38-S45, 2005.

SHAW, A. et al. Surveying "slides": clinical perception and clinical judgment in the construction of a genetic diagnosis. New Genetics and Society, 22: 3-19, 2003. SHOSTAK, S. Environmental justice and genomics: acting on the futures of environmental health. Science as Culture, 13: 539-562, 2004.

. The emergence of toxic genomics: a case study in molecularization. Social Studies of Science, 35: 367-403, 2005.

SILVA, T. T. D. (ed.). Antropologia do ciborgue: as vertigens do pós-humano. Belo Horizonte: Autêntica, 2000.

SINGH, D. et al. Gene expression correlates of clinical prostate cancer behaviors. Cancer Cell, 1: 203-209, 2002.

SOMMERLUND, J. Classifying microorganisms: the multiplicity of classification and research practices in molecular microbial ecology. Social Studies of Science, 36: 909-928, 2006.

STEINBERG, D. L. Bodies in glass: genetics, eugenics, embryo ethics. Manchester: Manchester University Press, 1997.

THACKER, E. Data made flesh: biotechnology and the discourse of the posthuman. Cultural Critique, 53: 72-97, 2003a.

.What is biomedia? Configurations, 11: 47-79, $2003 \mathrm{~b}$.

TOMASULA, S. Genetic art and the aesthetics of biology. Leonardo, 35: $137-$ 144, 2002.

VILAR, J.; GUET, C. \& LEIBLER, S. Modeling network dynamics: the lac operon, a case study. The Journal of Cell Biology, 161: 471-476, 2003.

WALDBY, C. The visible human project: informatic bodies and posthuman medicine. New York: Routledge, 2000.

WARR, T. \& JONES, A. The artist's body. London: Phaidon, 2000.

WEGENSTEIN, B. If you won't shoot me, at least delete me! Performance art from 1960 s wounds to 1990 s extensions. In: MITCHELL, R. \& THURTLE, P. 
(eds.). Data made flesh: embodying information. New York: Routledge, 2004. WILMUT, I.; CAMPBELL, K. \& TUDGE, C. The second creation: dolly and the age of biological control. Cambridge: Harvard University Press, 2000. YOXEN, E. Giving life a new meaning: the rise of the molecular biology establishment. In: ELIAS, N.; MARTINS, H. \& WHITLEY, R. (eds.). Scientific establishments and hierarchies. London: D. Reidel, 1982.
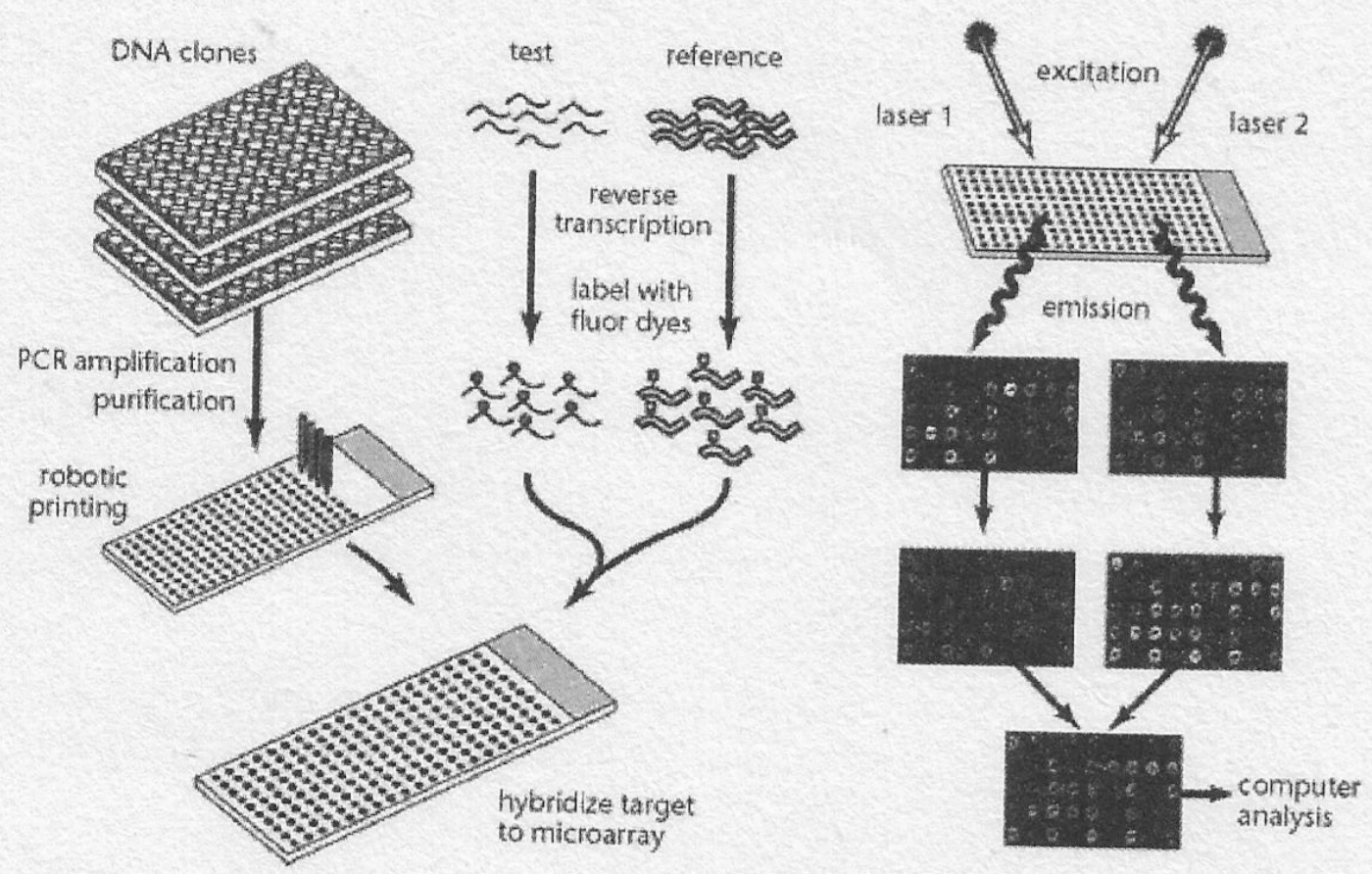

Figura 1: Esquema da construção do microarray (retirado de Duggan et al., 1999).

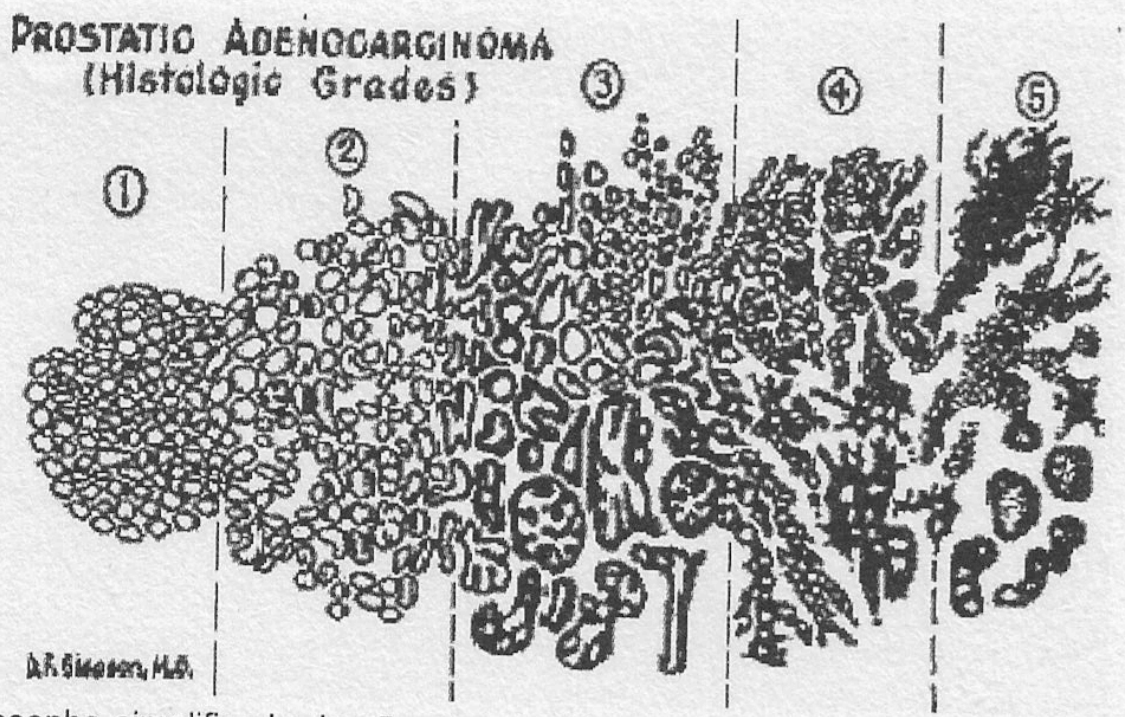

Figura 2: Desenho simplificado das 5 notas de Gleason [retirado de http://www.phoenix5.org/ Infolink/GleasonGrading.htm\#intro]. 


\section{PARTE III TECNOLOGIAS GENÉTICAS E IDENTIDADES ÉTNICO-RACIAIS EMERGENTES}




\section{USOS POLÍTICOS DA LEUCOPENIA E DIFERENÇA RACIAL NO BRASIL CONTEMPORÂNEO}

Elena Calvo-Gonzáles

\section{Introdução}

A associação entre raça, biologia e tecnologia remonta ao nascimento dos modelos científicos de classificação hierárquica da diversidade humana. Das medições de crânios do racismo científico do século XIX às análises genéticas contemporâneas sobre grupos populacionais que empregam como base de classificação das amostras tomadas diferentes grupos denominados abertamente de raças ou implicitamente coincidentes com grupos anteriormente tidos como raciais (estudos que, por sua vez, podem tanto refutar como confirmar a existência de raças enquanto realidades biológicas), há um elo histórico entre a aplicação de tecnologias na medição de certos corpos e a formulação de ideias sobre raça. Neste elo entre aplicação de tecnologias e construção de verdades científicas sobre a natureza racial, é central a contribuição das ciências, e especialmente da Biomedicina, tanto na formulação histórica das ideias sobre diferença racial, quanto na sua manutenção e reformulação contemporânea. Assim, o uso do termo raça tem sido mantido corriqueiramente em um número considerável de estudos da comunidade científica médica. Em muitas ocasiões o termo é empregado nestes estudos sem menção aos acalorados debates, seja dentro das ciências naturais ou das ciências sociais, em torno do seu uso. Já em outros casos, é feito um uso de maneira consciente (Rosenberg et al., 2003; Risch, 2000), com 
um posicionamento explícito de defesa do uso de categorias raciais, definidas num misto de ancestralidade autodeclarada e características físicas, da aparência externa ou de marcadores moleculares, como pertinentes para interpretar e lidar com a diferença biológica entre seres humanos e sua relevância para o desenvolvimento de certas doenças e seus agravos (Burchard et al., 2003; Mountain \& Risch, 2004). Estas posições têm levantado polêmica não somente em torno da validade científica da associação entre raça e doença, mas também em relação às categorias raciais serem ou não uma boa aproximação da ancestralidade biológica (Tishkoff \& Kidd, 2004; Pena, 2005; Ossorio \& Duster, 2005; Sinha et al., 2006; Frank, 2007).

Por outro lado, e apesar das críticas ao uso do conceito raça enquanto realidade biológica para a classificação dos indivíduos, o uso do termo enquanto construto social que impacta tanto em experiências de âmbito individual quanto de certos grupos tem sido mantido como categoria de análise até por autores que discordam da posição que acredita na existência biológica de diferenças raciais $a$ priori. O uso da categoria como construto social que impacta a vida e o cotidiano das pessoas pode ser dividido em duas grandes linhas. Uma primeira, que foca mais na análise de indicadores estatísticos para mostrar que, apesar de não serem realidades biológicas, as raças agem enquanto categorias nativas socialmente construídas em sistemas hierarquizados de racismo que contribuem para a reprodução das desigualdades em geral e das iniquidades em saúde em particular (Guimarães, 1999; Lopes, 2005). Esta abordagem se faz especialmente presente nos argumentos a favor de políticas públicas a serem implementadas para reduzir estas desigualdades, notadamente dentro do campo chamado de Saúde da População Negra (ver Maio \& Monteiro, 2005). A segunda abordagem aprofunda a análise de como estas categorias nativas agem, argumentando que, apesar de raça não constituir uma realidade biológica prévia, no entanto, e pelo fato de afetar o modo como as pessoas vivenciam o mundo, a 
raça é constitutiva dos corpos e dos processos de adoecimento destes (Dressler \& Santos, 2000).

O uso de raça enquanto construto social, e especialmente sua aplicação em políticas públicas, não está isento de críticas. Além de apontar o possível ofuscamento que o foco nas desigualdades raciais pode dar a outro tipo de desigualdade, como por exemplo econômica ou de classe (Souza, 2006), a maioria dessas críticas se refere à não possível separação entre raça como realidade social da sua linhagem enquanto categoria biológica. Para alguns destes autores, a história do conceito, assim como seu uso continuado em meios científicos ou popularmente como categoria de diferenciação biológica entre grupos, faz deste um termo que contribuiria para "fixar" as categorias raciais enquanto realidades biológicas existentes a priori fora de todo contexto social (Gilroy, 2000). No caso do Brasil, a estes argumentos (Azevedo, 2004; Pena, 2005) une-se a discussão sobre a suposta fluidez e multiplicidade das categorias raciais em uso no país, sobre a miscigenação como característica biológica e cultural do país, assim como sobre o uso de indicadores estatísticos de bem-estar como base de análise do impacto que a raça tem na configuração das desigualdades, questionando-se especialmente a junção estatística dentro da categoria "negro" da somatória de autoclassificados "pretos" e "pardos" (Fry, 2000; Carvalho, 2004; Santos \& Maio, 2005; Magnoli, 2005).

No contexto deste debate sobre a possível separação ou não da categoria raça entre realidade social ou biológica, assim como suas possíveis aplicações no campo das políticas públicas, são centrais os argumentos sobre a validez do tipo de verdade que dão legitimidade ao uso do termo. Neste sentido, a concepção moderna de raça, que pode ser traçada ao século XIX, já nasce, usando o termo de Bruno Latour (1991), como um híbrido entre sociedade e natureza (ver Wade, 2010). O termo raça mobiliza, desde a sua origem até os nossos dias, argumentos tanto sobre a natureza (ou biologia), através 
da medição e classificação de certas características físicas e morais dos corpos, quanto sobre a sociedade, no sentido do conceito estar inscrito dentro de relações hierarquizadas entre indivíduos e grupos populacionais ao mesmo tempo que contribui à significação destas relações.

Para analisar de que maneira esses discursos sobre raça enquanto realidade social ou biológica mobilizam verdades que, por sua vez, são mobilizadas politicamente, apresento dois estudos de caso, ambos localizados na Região Metropolitana de Salvador, Bahia. O primeiro lida com os argumentos empregados na década de 80 e 90 do século XX por parte de industriais sobre a natureza racial da contagem baixa de leucócitos (leucopenia) para explicar a existência desta entre operários da indústria química, atribuída por outras fontes, tais como entidades de classe e sindicatos, à existência de contaminação por benzeno entre estes trabalhadores. O segundo estudo de caso centra-se no uso da leucopenia como especificidade racial empregada tanto por ativistas da área política da Saúde da População Negra quanto por alguns cientistas em discussões em torno da necessidade de se estabelecer valores de referência ditos raciais para o leucograma. Pretendo com estes dois casos apontar como a construção das ideias sobre diferença racial estão relacionadas à constituição do modelo de verdades sobre o corpo dentro da Biomedicina. Ao mesmo tempo, sinalizo os usos políticos contemporâneos dessa associação entre leucopenia e negritude, tanto em contextos de esvaziamento de lutas sindicais, através da estigmatização do corpo negro enquanto "diferente", quanto de luta pelo reconhecimento da existência de iniquidades raciais em saúde no Brasil. Aponto assim o modo como as diferenças indicadas pela tecnologia de contagem de leucócitos são ressignificadas no contexto contemporâneo de uso das categorias "negro" e "população negra" dentro de discussões sobre desigualdades sociais pautadas numa releitura da sociedade brasileira. 


\section{Leucopenia: sobre modelos de medicina}

O estabelecimento da leucopenia como condição médica deve muito à mudança de "estrutura profunda" no século XIX apontada por Michel Foucault, que implicaria passar a considerar a doença, de uma entidade que habitava o doente, uma condição processual do corpo. Esta mudança é associada por Foucault à reorganização da profissão e treinamento médico, ao surgimento de técnicas investigativas, assim como à transformação da clínica como lugar onde os corpos dos pacientes são objeto desse novo modo de olhar (Foucault, 1976). Após essa mudança, o diagnóstico não podia ser mais feito simplesmente escutando as queixas e experiências vividas dos pacientes e consultando tabelas nosológicas, precisando-se da aplicação de tecnologias para chegar ao diagnóstico por meio da análise do corpo do paciente. Apesar da importância do estabelecimento da clínica enquanto espaço nessa mudança de paradigma, no final do século XIX a maioria do conhecimento sobre as doenças ainda era produzida pelo médico de família dentro de um modelo de individualismo médico. O deslocamento da produção de verdades médicas para lugares tais como laboratórios de patologia localizados dentro de hospitais se aprofundaria no começo do século XX, quando, segundo Keith Wailoo (1999), podemos traçar a mudança de poder em direção aos centros de pesquisa médicos. Esta mudança viria acompanhada do desenvolvimento e da popularização de técnicas cada vez mais refinadas de diagnóstico médico. Assim, por exemplo, apesar das primeiras técnicas de contagem de leucócitos através de esfregaço sanguíneo com uso de colorações datar do final do século XIX, quando Paul Ehrlich conseguiu identificar três tipos de leucócitos (neutrófilos, basófilos e eosinófilos, nomeados de acordo às colorações usadas para identificá-los) (Weaver, 1954), não seria até o século XX que as técnicas de contagem de células sanguíneas seriam popularizadas, datando de 1910 o primeiro departamento de sangue (as chamadas blood wards), no Hospital Geral de Massachussets nos Estados Unidos (Wailoo 1999: 85). As verdades que as tecnologias mé- 
dicas de exame do sangue aplicadas nos laboratórios poderiam produzir sobre as doenças, identificando e inclusive criando novas condições médicas, influiriam de maneira importante nas concepções sobre a "natureza" do corpo, tal e como Emily Martin mostra no seu estudo sobre a imunologia e o modelo contemporâneo de corpo "flexível" (Martin, 1994). Apesar das tecnologias médicas terem que disputar a primazia em diferentes momentos históricos com outras abordagens médicas, como por exemplo a anatomia post-mortem, o tamanho do seu sucesso só pode ser medido pelo refinamento cada vez maior e pela popularização dessas tecnologias, que passam a ser empregadas corriqueiramente em vários contextos de atenção à saúde. $\mathrm{O}$ uso cada vez mais cotidiano dessas tecnologias impacta as concepções sobre corpo e raça tanto de médicos quanto, como veremos mais adiante, de pacientes.

No entanto, as mudanças nessas concepções da natureza biológica dos corpos passariam pelo estabelecimento de um consenso em torno aos significados dessas técnicas enquanto canais para acessar a verdade dos corpos. Nesse sentido, o estabelecimento de um consenso médico em relação aos valores considerados normais e anormais dos resultados da aplicação de tecnologias de análise de componentes do sangue, e da legitimidade de outras representações do porquê desses valores, como veremos nos estudos de caso a serem analisados, estão inseridos nas lutas de poder sobre a construção de verdades em relação ao âmbito do biológico e do social.

\section{Leucopenia na indústria: sobre exposição ao benzeno e a natureza dos corpos dos trabalhadores}

O reconhecimento da existência de um elo entre a exposição ao benzeno e o surgimento de sintomas de doença está intimamente ligado ao desenvolvimento de técnicas hematológicas. A identificação, na década de 1910, de um histórico de exposição ao benzeno em indústrias dos Estados Unidos como causadora de destruição de 
células sanguíneas (na condição médica chamada à época de anemia aplástica) está relacionada à identificação de lesões medulares em pacientes já falecidos ou à identificação da queda do número de células sanguíneas em pacientes vivos. E, mais ainda, esta identificação precoce - na década de 1910 nos Estados Unidos - nos remete à ideia de diferença de corpos, mesmo antes da exposição ao benzeno estar associada à leucopenia e de esta estar identificada, por sua vez e dentre outras situações que podem provocá-la, à natureza biológica do corpo negro. Assim, Alicia Hamilton, uma ativista da saúde pública que na década de 1910 tinha identificado a anemia aplástica causada pelo benzenismo (ou envenenamento por benzol, como era denominado nessa época) como o trágico final no drama dos trabalhadores fabris explorados nas indústrias, passaria, em meados da década de 20, a considerar a doença como um problema da sensibilidade de certos indivíduos ao benzeno e de práticas não adequadas de manejo da quantidade e tempo de exposição ao produto ao qual estes trabalhadores mais sensíveis poderiam estar submetidos (Wailoo, 1999: 93-95). O foco central no controle do benzenismo, no lugar de se centrar na proibição de qualquer exposição à substância, passaria a ser feito pelo controle periódico da saúde dos trabalhadores, incluindo o monitoramento das jornadas perdidas por motivo de doença e a aplicação periódica de exames de sangue para verificar a presença de anemia aplástica. O problema não era o produto químico, e sim as especificidades biológicas (ou da natureza) de certos corpos.

Esta argumentação sobre a "especificidade" de certos corpos em relação à exposição ao benzeno retornaria nos argumentos da década de 80 sobre benzenismo e leucopenia no Brasil. A identificação da leucopenia como estágio anterior ao desenvolvimento de consequências mais graves do benzenismo, e por conseguinte passível de intervenção na vida do trabalhador afastando-o da exposição ao produto químico supostamente causadora do problema - seja através do remanejamento dentro da indústria para atividades que não têm 
contato com o produto, seja para seu afastamento definitivo - segue a linha do monitoramento aos trabalhadores expostos ao benzeno como solução para o problema da intoxicação por benzeno (Augusto \& Novaes, 1999). Porém, a mesma condição leucopênica considerada como acidente de trabalho, podendo o portador receber direitos da Previdência Socia, como "auxílio-doença" ou "aposentadoria por invalidez", é considerada pela hematologia e pela própria clínica do trabalho como inconclusiva da condição de caso de benzenismo (Correia, 1998). Assim, para a prática da hematologia, a contagem baixa de leucócitos não pode fornecer um dado conclusivo de benzenismo, pois pode não haver uma relação necessária entre exposição ao benzeno e surgimento de leucopenia, nem entre a exposição ao benzeno, o grau de leucopenia e o desenvolvimento de aplasias e leucemias como consequência dessa exposição. ${ }^{1}$ Além da leucopenia, precisa haver outras manifestações do benzenismo, seja por comprovação de lesão de medula (também, por outro lado, considerada pela hematologia como inconclusiva) ou da exposição ao benzeno no ambiente de trabalho, requerendo assim medidas que estão fora do âmbito da hematologia. Ao mesmo tempo, e segundo alguns textos da hematologia, a leucopenia pode ser considerada como condição de normalidade de certos indivíduos, o que faria com que, segundo alguns autores, como o hematologista baiano Celso Guerra, caso o valor de referência tido como normal seja de 5.000 leucócitos por milímetro cúbico de sangue (considerado no começo da década de 80 como valor de referência), $5 \%$ da população do Brasil seria considerada leucopênica. Para este hematologista, que representa a visão da leucopenia enquanto condição do corpo negro, há trabalhos, no Brasil e no exterior, que "aceitam o valor de 4000 glóbulos brancos para a raça branca como limite para definir leucopenia e merecer alguma atenção do médico". Guerra continua argumentando que

1 Sobre a diferença entre as abordagens da Medicina do Trabalho e da Saúde do Trabalhador em relação ao caso de leucopenia e benzenismo, ver Augusto \& Novaes (1999). 
"não podemos esquecer que as pessoas descendentes de raça negra apresentam como regra (ênfase minha) valores mais baixos de glóbulos brancos" (Guerra apud Correia, 1998: 1). A raça branca, assim como sua "oposta", a raça negra, são consideradas como sendo tão evidentes que não precisam de uma definição para delimitar quem seriam, no Brasil, os indivíduos considerados como pertencentes à primeira e aqueles pertencentes à segunda. Note-se, assim mesmo, a ausência, apontada por Costa (2002), de amarelos e indígenas dentro desse esquema de divisão racial bipolar (negro/branco) da população. O argumento da especificidade racial da leucopenia e sua negação como marcador para casos de benzenismo nessas situações é ilustrado no seguinte diálogo entre um médico do trabalho e Mateus, um trabalhador do Polo Petroquímico de Camaçari, que o sociólogo Luiz Correia relata:

Mateus: Doutor, eu estou com um problema que eu nunca tive, eu estou sentindo uns sintomas e eu acho que devo me afastar pra ver se eu ainda tenho recuperação...

Médico: Você não tem nada pra se afastar, você é de onde? Mateus: Eu sou baiano.

Médico: Mas você, raça mestiça, raça negra, tem tudo pra ter os leucócitos baixos...

Mateus: Mas doutor, antigamente, eu vou mostrar aqui pro senhor alguns exames que eu fiz antigamente, tá vendo aqui doutor? Meus resultados [de exames de leucograma] têm 7500, 7200 , nessa época eu era branco? Porque hoje estou com um problema adquirido aqui dentro da empresa eu sou preto?

Médico: Não comente isso com ninguém, não fale com seu chefe não...

Mateus: Eu acho que eu tenho que falar, o senhor me disse que eu era preto porque eu estou doente...

Médico: Ora rapaz, se você quer se complicar, se você quer se afastar, eu vou the encaminhar para o INSS... (Correia, 1998: 174) 
A associação da leucopenia como condição do corpo negro foi fortemente contestada pelos sindicatos tanto na Bahia quanto nacionalmente. Assim, o hematologista Celso Guerra, citado anteriormente, foi identificado por ativistas sindicais, em reuniões e publicações, como um dos atores interessados em manter a associação entre leucopenia e corpo negro com a intenção de proteger os interesses das indústrias envolvidas nos casos de benzenismo. ${ }^{2}$ Para os sindicalistas, $o$ argumento racial para explicar a diferença no valor de referência da contagem de leucócitos torna-se assim parte do processo de luta de classes. Este processo de significação do corpo negro dentro da luta de classe estaria exemplificado no uso do argumento da especificidade racial da leucopenia pelas indústrias em processos trabalhistas envolvendo trabalhadores que apresentavam esta condição.

Por outro lado, se há uma rejeição entre sindicalistas a esta associação entre leucopenia e corpo negro, há ao mesmo tempo um desconforto entre certos setores do sindicalismo e entre muitos trabalhadores devido ao fato que, nos exames pré-admissionais instituídos no processo de lutas em torno ao benzenismo como necessários para conseguir emprego nestas indústrias, inclusive para posteriormente poder comprovar a condição leucopênica como resultante de exposição industrial ao benzeno, alguns indivíduos eram identificados como leucopênicos e não eram contratados. A associação entre leucopenia e "corpos desviantes" levou à estigmatização e a exclusão destes trabalhadores de um dos mercados de trabalho que, dentro do contexto do estado da Bahia e, até pouco tempo atrás, oferecia melhores salários e condições de trabalho para trabalhadores sem formação de nível superior (Agier, Castro \& Guimarães 1995). Sendo que o trabalho na indústria petroquímica era uma das avenidas para a mobilidade social de grupos não brancos na Bahia, a não contratação supunha uma perda de oportunidades econômicas e de ascensão social que, por sua vez,

2 Ver Vanguarda Operária, n. 2, ago./out. 1997. Disponível em: <http://www.internationalist. org/leucopenia.html>. Acesso em 07/12/2009. 
teriam um impacto no processo de desestigmatização do corpo negro através da possibilidade do incremento do consumo e a valorização que este tem na sociedade contemporânea (Sansone, 2002; 2004).

De certa maneira, a condição ambígua da leucopenia dentro da hematologia leva ao seu uso contraditório e, poder-se-ia argumentar, manipulador dentro do âmbito trabalhista. Assim, dentro do contexto do mercado de trabalho, a leucopenia ora era considerada como condição normal do corpo negro nos processos trabalhistas, ora como incapacitante para contratação. A associação entre leucopenia e corpo negro implica, por sua vez, a associação da população da Bahia com uma imagem de população "de cor", "suspeita" de miscigenação mesmo quando o indivíduo não apresenta marcas fenotípicas externas de ancestralidade africana. A condição ambígua das características raciais da população baiana se apresenta como pairando sobre todos os corpos, podendo ser invocada por motivos políticos. No entanto, e como veremos na discussão sobre a necessidade de se estabelecer valores de referência raciais para o leucograma, a ambiguidade do caráter racial da população baiana pode não ser mobilizada em contextos que associam a condição leucopênica à condição do corpo negro, a depender dos atores envolvidos.

\section{Diferença racial implica em diferentes valores?}

A primeira vez que presenciei a menção à diferença de valores de referência para o leucograma de caráter racial foi durante minha pesquisa de campo em um hospital na Bahia que cuida de pacientes com doenças hematológicas, ${ }^{3}$ onde testemunhei o seguinte intercâmbio entre uma médica da instituição e uma paciente. Apresentando resultados de contagem baixa de leucócitos num hemograma

3 Na época em que presenciei este intercâmbio, o motivo de minha presença nesta instituição de saúde era a realização de uma pesquisa (aprovada pelo comitê de ética da Fiocruz-CPqGM, parecer número 93/2006) sobre os processos através dos quais a doença falciforme se apresentava, dentro e fora de contextos médicos, enquanto "doença da população negra" (ver Fry, 2005; Laguardia, 2006). 
realizado a pedido de seu médico, a paciente, uma mulher jovem moradora do interior da Bahia, tinha sido encaminhada à triagem do serviço de referência em hematologia. A médica que naquele dia estava encarregada de realizar a triagem olhou para os exames da paciente e logo argumentou:

"- Pode ficar tranquila com esses seus neutrófilos, ô, eu também tenho eles baixos, é normal na população negra... pode parecer que não, mas eu também tenho um pé na cozinha!".

A paciente, da mesma cor da médica, o que localmente é chamado, dentre outros termos, de "morena clara", olhou de novo para a médica e deu um sorriso tímido para a sua acompanhante, uma mulher de meia-idade, de tonalidade de pele parecida. Quando a médica saiu para ir procurar um documento relacionado ao prontuário da paciente, esta se voltou para a sua acompanhante e, em voz baixa e apontando para um pelo que a acompanhante tinha no braço, que se destacava por ser mais comprido do que os outros, disse "isso aí é por causa da mistura, aí saem essas coisas loucas, não ouviu a doutora, não?".

Essa identificação entre leucopenia e população negra se apresentaria de novo mais tarde quando fui convidada a participar, como pesquisadora associada ao Centro de Estudos Afro-orientais da Universidade Federal da Bahia, de um encontro organizado pelo Laboratório de Imunologia e Biologia Molecular do Instituto de Ciências da Saúde dessa mesma universidade, intitulado "Aspectos étnicos e valores de referência de parâmetros clínicos laboratoriais". Nesse encontro, a leucopenia, de novo, surgiu como exemplo da necessidade de se adequar os dados empregados como valores de referência nos laboratórios de análises clínicas à realidade da diversidade racial da população baiana. Esse evento contou com a participação de uma geneticista, duas biólogas, duas ativistas do campo da Saúde da População Negra, alunos do programa de pós-graduação em imunologia da UFBA e dois antropólogos, um deles, eu. Segundo argumentos de uma das biólogas que tinha organizado o evento, o objetivo da 
reunião era discutir a necessidade de se estabelecer valores de referência ditos étnicos para alguns exames laboratoriais. Dentre esses exames, estava o leucograma. A bioquímica que coordenava o evento explicou que auxiliares de enfermagem que trabalhavam no centro de referência de hematologia do estado tinham que pedir a certos pacientes que, antes de retirar o sangue, dessem uma volta no prédio para que os valores dos exames desses indivíduos "batessem" com os valores de referência tidos como normais. ${ }^{4}$ Após a apresentação de todos os participantes, abriu-se espaço para apresentações de dados e debate. A geneticista participante fez uma apresentação empregando dados sobre marcadores de ancestralidade genômica, sobre a natureza miscigenada da população brasileira. Uma das ativistas da Saúde da População Negra, que trabalhava para a Secretaria Municipal de Saúde da prefeitura de Salvador, argumentou pela necessidade de se adequar os valores que eram usados como referência, pois, segundo ela, estes correspondiam aos valores de branco e não eram adequados à realidade da população baiana. Segundo esta ativista, haveria um descompasso entre os saberes da medicina e a realidade da população baiana, o que levaria à negação das especificidades da população local. Uma das bioquímicas participantes expandiu esse argumento, indicando como os valores de referência atuais faziam com que muitos dos exames de baianos dessem alterados quando, na verdade, tinham valores normais, só que não eram considerados como tais. A discussão centrou-se, então, na necessidade de se estabelecer uns valores que fossem adequados. Questionada pela população entre a qual tinham sido feitos estudos que tinham dado lugar aos valores de referência existentes na atualidade, duas das participantes do departamento de Imunologia da UFBA indicaram que estes tinham sido feitos sob financiamento de companhias farmacêuticas, na Europa e nos Estados Unidos, apontando como estes dados eram "de

\footnotetext{
4 Após esforço físico intenso, há uma condição transitória de aumento da contagem de
leucócitos (Guerra et al., 1987).
} 
branco". Perguntei se havia dados locais sobre os valores médios da população local, tanto branca quanto negra, obtendo uma resposta negativa e apontando uma pesquisa na época em andamento sobre este tema. ${ }^{5} \mathrm{O}$ interessante foi que, durante a discussão, em momento nenhum foi mencionada outra categoria racial que não a de branco, exceto na apresentação, por parte do outro antropólogo participante, de fotografias de um município do interior da Bahia e no comentário feito por ele de como havia um elo entre negritude e pobreza que, segundo ele, poderia ser estendido ao resto da Bahia. Uma aluna da pós-graduação em imunologia questionou esta equação entre pobreza e negritude, argumentando que, no interior do estado, existiam comunidades nas quais as pessoas se autoidentificavam como brancas e no entanto viviam em condições extremas de pobreza. Ao mesmo tempo, questionou a ideia de que todo mundo que não fosse considerado branco se considerasse a si mesmo como negro, argumento que não foi levado adiante, nem obteve resposta por parte de nenhum dos apresentadores ou participantes no encontro.

Inexistia então uma reflexão sobre o lugar dessas futuras categorias étnicas de valores de referência de pessoas que são classificadas localmente como estando racialmente entre a categoria de branco e de negro. Um dos hipotéticos motivos para explicar a ausência do termo moreno ou mestiço nessas discussões, ausência que naquele momento chamou poderosamente a minha atenção, é a aceitação, dentro do ambiente acadêmico, de uma maneira mais fácil do sistema de classificação racial que considera negro qualquer pessoa com fenótipo externo que apresenta alguma marca identificada como de ascendência africana (como por exemplo ter o cabelo crespo). Ao

5 Em 2010 seriam publicados os resultados de uma pesquisa com 289 doadores de sangue na Bahia que não encontrou diferenças significativas relacionadas ao valor "etnia" (no original publicado em inglês, empregou-se o conceito "ethnicity", enquanto conceito [traduzido como "etnia" no resumo em português], "Blacks" enquanto categoria de autoclassificação dos participantes e "African-american" na comparação dos resultados obtidos com os de outros estudos, não apontando a equivalência em português da categoria "Black" usada no texto [Felix et al., 2010]). 
mesmo tempo, é importante levar em conta que a implementação de um sistema de classificação que considere todas as pessoas que têm algum grau de ancestralidade visível (os autoclassificados pardos na coleta de dados estatísticos pelo estado, ou comumente chamados de morenos ou mestiços) é um ponto central nas lutas de movimentos sociais negros. O argumento por trás da justificativa desse sistema é tanto estatística, pois os indicadores estatísticos destas duas categorias são mais próximos do que a de ambos com a categoria branco, quanto a consideração da categoria intermediária como responsável por escamotear a identidade negra, onde o processo ideológico e histórico (por exemplo através do fomento à imigração europeia) de embranquecimento do país é considerado responsável pela valorização ideológica e estética da branquitude, o que levaria muitos indivíduos a se autodescreverem com a categoria identitária pardo no lugar de usar a categoria preto (Guimarães, 1999).

Por outro lado, as falas das ativistas da Saúde da População Negra estavam fortemente permeadas, assim como fora na apresentação do antropólogo sobre a pobreza da comunidade do interior, por um apelo à necessidade de se fazer justiça à população da Bahia, que era considerada predominantemente negra e, enquanto tal, discriminada ou, quando menos, não atendida pelas políticas públicas do Estado. Esta noção de justiça incluía o ajuste à realidade local do uso da tecnologia de contagem de leucócitos e sua leitura através dos valores de referência considerados normais. Foram relembrados os casos de trabalhadores rejeitados pela indústria por não passarem no exame médico admissional, que já tinha comentado na seção anterior. Assim, a questão da justiça social era apresentada por estes atores como a capacidade do estabelecimento médico de aceitar a diferença dessa população, diferença no caso associada à natureza do corpo negro.

O que este estudo de caso nos aponta é como a construção da diferença relacionada ao corpo negro pode estar perpassada tanto por noções associadas ao mundo da biologia quanto por noções sobre a 
sociedade, tais como desigualdade, justiça, e a necessidade de lidar com essas iniquidades.

\section{Conclusão}

Apesar de se apresentar em contextos diferentes, considerei a presença de maneiras próximas de se falar sobre raça nos dois estudos de caso como um ponto interessante para comparar a leitura sobre a diferença dos corpos e como esta é reinterpretada com base em noções de raça ligadas ao campo da biologia ou da sociedade. Em ambos os estudos de caso apresentados no meu argumento, a noção de diferença racial enquanto biológica é feita criando-se um elo entre corpos presentes e ausentes, de diferentes países e momentos históricos, no caso através da consideração de que os dados apresentados em pesquisas dos Estados Unidos e Europa são aplicáveis à população baiana. No entanto, se por um lado a leucopenia é interpretada como condição natural, associada a características biológicas do corpo negro, tanto por empresários quanto por ativistas da Saúde da População Negra ou profissionais que trabalham na área da biomedicina (incluindo cientistas), por outro, a descrição da leucopenia como causada pelo contexto trabalhista (e legal) que permite a exposição dos trabalhadores ao benzeno em algumas indústrias nos remete a noções sobre desigualdade e posição social que não necessariamente concebem a diferença em termos biológicos. Da mesma maneira que as lutas sindicais em relação à contaminação por benzeno dos trabalhadores estão ligadas à concepção da posição destes atores em relações de poder mediadas pela ideia de classe, as lutas dos ativistas da Saúde da População Negra estão ligadas à noção de posição desigual dentro da sociedade brasileira. Porém, ativistas da Saúde da População Negra incorporam à concepção de posição desigual na sociedade o conceito de diferença do corpo negro. As iniquidades em saúde são traduzidas, nos discursos e escritos de militantes desse campo político, tanto pela posição subordinada da população negra e o desinteresse do 
Estado na mudança desta, em argumentos que enfatizam a construção social da desigualdade, quanto na negação por parte de atores do Estado da diferença do corpo negro. Por exemplo, nos relatos sobre ignorância por parte dos médicos que atendem essa população em relação às doenças e especificidades em saúde da população negra, os militantes do campo político da Saúde da População Negra, algum deles inclusive já incorporados em instâncias de poder do Estado, interpretam este tipo de situação ora como preconceito desses profissionais e do Estado, nos conceitos de racismo e racismo institucional respectivamente, ora como inabilidade ou desinteresse por parte do Estado, através dos seus agentes do sistema de saúde, em lidar com essa diferença natural entre corpos. Assim, uma maneira de falar sobre raça enquanto termo social é empregada nesses discursos ao mesmo tempo que são mobilizadas noções sobre raça biológica, sem haver uma diferenciação clara de que conceito é empregado em que momento.

Esta dificuldade em separar raça social de raça biológica pode ser traçada à qualidade de híbrido deste conceito, assim como ao fracasso do processo de separação entre natureza, ou biologia e sociedade. Assim, o uso do termo raça implica necessariamente que ambos os âmbitos vão estar mobilizados, tal como mostram os discursos dos diversos atores envolvidos na discussão sobre a especificidade racial da leucopenia. Esta mobilização pode ser feita tanto de uma maneira consciente, como os estudos de caso apresentados neste trabalho, quanto de um modo não consciente na vida cotidiana, sendo que os corpos no Brasil experienciam o mundo através de categorias raciais fruto de processos históricos que impactam o seu dia a dia.

\section{Referências}

AGIER, M; CASTRO, N. \& GUIMARÃES, A. S. Imagens e identidades do trabalho. São Paulo: Hucitec, 1995.

AUGUSTO, L. G. da S. \& NOVAES, T. C. P. Ação médico-social no caso do 
benzenismo em Cubatão, São Paulo: uma abordagem interdisciplinar. Cadernos de Saúde Pública, 15(4): 729-738, 1999.

AZEVEDO, C. M. M. de. Anti-racismo e seus paradoxos: reflexões sobre cota racial, raça e racismo. São Paulo: Annablume, 2004.

BURCHARD, E. G. et al. The importance of race and ethnic background in biomedical research and clinical practice. New England Journal of Medicine, 348: 1.170, 2003.

CARVALHO, J. M. de. Genocídio racial estatístico. O Globo, Rio de Janeiro, 27 dez. 2004.

CORREIA, L. A Epidemia de um estigma: leucopenia e benzenismo entre trabalhadores do Pólo Petroquímico de Camaçari, 1998. Dissertação de Mestrado, Salvador: Universidade Federal da Bahia.

COSTA, S. A construção sociológica da raça no Brasil. Estudos Afro-Asiáticos, 24(1): 35-61, 2002.

DRESSLER, W. \& SANTOS, J. E. dos. Social and cultural dimensions of hypertension in Brazil: a review. Cadernos de Saúde Pública, 16 (2): 303-315, 2000. FELIX, G. E. S. et al. Ancestry informative markers and complete blood count parameters in Brazilian blood donors. Revista Brasileira de Hematologia e Hemoterapia, 32(4): 282-285, 2010. Disponível em: <http://www.scielo.br/ scielo.php?script=sci_arttext\&pid=S1516-84842010000400003\&lng=en\&nr $\mathrm{m}=\mathrm{iso}>$. Acesso em: 25 dez. 2010.

FOUCAULT, M. The birth of the clinic: and archaeology of medical perception. London: Tavistock, 1976.

FRANK, R. What to make of it? The (re)emergence of a biological conceptualization of race in health disparities research. Social Science \& Medicine, 64(10): 1.977-1983, 2007.

FRY, P. H. Politics, Nationality and the Meaning of 'Race' in Brazil. Daedalus, 129(2): 83-118, 2000.

- O significado da anemia falciforme no contexto da "política racial" do governo brasileiro 1995-2004. História, Ciências, Saúde - Manguinhos, 12: 347-370, 2005.

GILROY, P. Against race: imagining political culture beyond the color line. Cambridge: Harvard University Press, 2000. 
GUERRA, C. C. C. et al. Valores de leucócitos em um grupo de trabalhadores rurais. Boletim da Sociedade Brasileira de Hematologia e Hemoterapia, 9(144): GUIMARÃES, A. S. A. Racismo e anti-racismo no Brasil. São Paulo: Editora
34, 1999.

LAGUARDIA, J. No fio da navalha: anemia falciforme, raça e as implicações no cuidado à saúde. Estudos Feministas, 14(1): 336, 2006.

LATOUR, B. Nous n'avons jamais été modernes. Paris: La Découverte, 1991. LOPES, F. Para além da barreira dos números: desigualdades raciais e saúde. Cadernos de Saúde Pública, 21(5): 1.595-1.601, 2005.

MAGNOLI, D. Pardos. Folha de S. Paulo, São Paulo, 21 abr. 2005.

MAIO, M. C. \& MONTEIRO, S. Tempos de racialização: o caso da "saúde da população negra" no Brasil. História, Ciências, Saúde-Manguinhos, 12(2): 419-446, 2005.

MARTIN, E. Flexible bodies: tracking immunity in American culture from the days of polio to the age of Aids. Boston: Beacon Press, 1994.

MOUNTAIN, J. L. \& RISCH, N. Assessing genetic contributions to phenotypic differences among "racial" and "ethnic" groups. Nature Genetics, 36: S48-S53, 2004.

OSSORIO, P. \& DUSTER, T. Race and genetics: controversies in biomedical, behavioral, and forensic sciences. American Psychologist, 60: 115, 2005.

PENA, S. D. J. Razões para banir o conceito de raça da medicina brasileira. História, Ciências, Saúde - Manguinhos, 12(1): 321-346, 2005.

RISCH, N. J. Searching for genetic determinants in the new millennium. Nature, 405: 847, 2000.

ROSENBERG, N. A. et al. Informativeness of genetic markers for inference of ancestry. American Journal of Human Genetics, 73: 1.402, 2003.

SANSONE, L. Não trabalho, consumo e identidade negra: uma comparação entre Rio e Salvador. In: MAGGIE, Y. \& REZENDE, C. B. (orgs.). Raça como retórica: a construção da diferença. Rio de Janeiro: Civilização Brasileira, 2002. Negritude sem etnicidade: o local e o global nas relações raciais e na produção cultural negra no Brasil. Salvador: Edufba/Pallas, 2004. SANTOS, R. V. \& MAIO, M. C. Política de cotas raciais, os "olhos da socieda- 
de" e os usos da antropologia: o caso do vestibular da Universidade de Brasília (UnB). Horizontes Antropológicos, 11(23): 181-214, 2005.

SINHA, M. M. et al. Self-reported race and genetic admixture. New England Journal of Medicine, 354: 421, 2006.

SOUZA, J. A visibilidade da raça e a invisibilidade da classe. In: SOUZA, J. (ed.). A invisibilidade da desigualdade brasileira. Belo Horizonte: UFMG, 2006. TISHKOFF, S. A. \& KIDD, K. K. Implications of biogeography of human populations for 'race' and medicine. Nature Genetics, 36(11): S21-S27, 2004 VANGUARDA OPERÁRIA, 2, ago.-out. 1997. Disponível em: <http://www. internationalist.org/leucopenia.html>. Acesso em: 07 dez. 2009.

WADE, P. The presence and absence of race. Patterns of Prejudice, 44(1): 43-60, 2010.

WAILOO, K. Drawing blood: technology and disease in twentieth century America. Baltimore: Johns Hopkins University Press, 1999.

WEAVER, A. D. The development of the knowledge of the leukocyte. Bulletin of the New York Academy of Medicine, 30(12): 988-992, 1954. 


\section{A IMPORTÂNCIA DE SER URO: MOVIMENTOS INDÍGENAS, POLÍTICAS DE IDENTIDADE E PESQUISA GENÉTICA NOS ANDES PERUANOS}

Michael Kent

Em novembro de 2008 ocorreu um encontro inusitado na cidade peruana de Puno, à beira do lago Titicaca. ${ }^{1}$ No lobby de um hotel se reuniram o prefeito, os vereadores e outras autoridades dos Uros, um pequeno grupo indígena que mora em ilhas flutuantes artificiais no meio do lago, com uma equipe de geneticistas. Neste último grupo estava presente o professor Fabrício Santos, da Universidade Federal de Minas Gerais - coordenador do projeto Genográfico ${ }^{2}$ para a América do Sul - e o professor Ricardo Fujita, da Universidad de San Martín de Porres, de Lima, o qual já tinha desenvolvido pesquisas genéticas anteriores sobre os Uros em parceria com José Sandoval (Córdova et al., 2008; Delgado Silva, et al. 2002; Sandoval et al., 2004). A reunião com os Uros visava

1 Este trabalho resulta de uma reflexão desenvolvida no âmbito do projeto "Raça, genômica e mestiçagem na América Latina: uma abordagem comparativa", financiada pelo Economic and Social Research Council do Reino Unido. A pesquisa foi financiada pela School of Social Sciences da Universidade de Manchester entre 2004 e 2007, com um total de 15 meses de trabalho de campo na baía de Puno. O Royal Anthropological Institute contribuiu com um Sutasoma Award em 2008. Informações adicionais foram coletadas durante breves visitas ao campo em novembro de 2008 e setembro de 2010. Agradeço particularmente a Thereza Menezes, Peter Wade, Ricardo Ventura Santos, Penny Harvey, John Gledhill, Olivia Harris (falecida) e Karen Sykes por seus comentários e outras valiosas contribuições ao desenvolvimento desta reflexão. O presente capítulo é uma versão revisada de artigo com o mesmo título publicado em Horizontes Antropológicos (volume 17, p. 297-324, 2011). Agradeço a Claudia Fonseca e demais colegas desta revista por suas valiosas revisões.

2 O nome é derivado do patrocinador principal do projeto, a National Geographic Society. 
apresentar-lhes os resultados preliminares de amostras coletadas entre eles no ano anterior.

Diferentemente do mundo indígena amazônico, nos Andes pequenos grupos relativamente isolados não são comuns. Ao contrário, a população indígena - constituída principalmente por Aymaras e Quéchuas - é contada aos milhões, e um contato intenso com o mundo não indígena foi estabelecido há séculos. A população assentada ao redor do lago Titicaca se estima em 1,5 milhão, com a maior cidade sendo a capital regional de Puno, com 120 mil habitantes. Nesse quadro, os Uros representam a única exceção. Com uma população pequena, de aproximadamente duas mil pessoas, seu habitat até há pouco era relativamente isolado no meio dos extensos campos de junco da baía de Puno. Eles se consideram como descendentes dos antigos Urus, ${ }^{3}$ geralmente reconhecidos como o primeiro grande grupo étnico dos Andes (Wachtel, 1990). As autoridades dos Uros têm usado essa identidade diferenciada na luta por maior autonomia territorial frente a uma área protegida pelo Estado - a Reserva Nacional del Titicaca, criada em 1978 - e populações ribeirinhas Aymaras e Quéchuas que reivindicam parte do mesmo território.

No encontro em questão, os geneticistas tinham ótimas notícias para oferecer às autoridades dos Uros: as pesquisas deles demonstraram que os Uros ainda conservam um importante componente genético diferencial no seu DNA, provavelmente derivado dos antigos Urus. Entre outras coisas, as análises revelaram a existência de alelos próprios, ou seja, características genéticas que são únicas e não se encontram em nenhuma outra população. ${ }^{4}$ Os Uros presentes receberem a notícia com grande entusiasmo. O prefeito Julio Vilca, entre os Uros, era um dos principais articuladores de uma identidade étnica diferenciada, ressaltou que esse estudo poderia ajudá-los

3 Reparar a ortografia diferente usada para se referir aos Urus pré-colombianos. Essa ortografia é usada também pelos três grupos bolivianos que reivindicam a mesma descendência.

4 A ocorrência de alelos próprios é pouco frequente em populações andinas. 
muito na luta pelos seus direitos. O clima de efusão tomou conta dos geneticistas também, resultando numa troca de ideias sobre como os estudos deles poderiam ajudar na reivindicação dos direitos indígenas. Depois do encontro, o prefeito Julio deu várias entrevistas a mídias locais e nacionais nas quais afirmou que "os cientistas da National Geographic acabam de confirmar que eu sim sou Uro, e que meu povo é o mais antigo dos Andes". 5

Os Uros encontraram entre os geneticistas raros aliados na luta por sua identidade étnica, que costuma ser fortemente contestada por diversos segmentos sociais em Puno. Geralmente eram considerados como Aymaras, não só por seus oponentes dentro do Estado, mas também por grande parte da elite intelectual, por antropólogos da Universidad Nacional del Altiplano sediada em Puno e até pelos próprios guias turísticos que vivem das visitas às ilhas flutuantes dos Uros. Uma breve anedota serve como ilustração. Rosita Pino, irmã da coordenadora do Centro Cultural Casa del Corregidor, que foi o primeiro espaço em Puno a divulgar as pesquisas de Fujita e Sandoval, narrava da seguinte maneira um passeio que fez às ilhas flutuantes no começo de 2008: "Quando chegamos às ilhas, o guia como sempre começou a dizer que os Uros não são Uros de verdade. Então perguntei por que ele dizia isso. 'Eu estudei as crônicas e então eu sei como eram os Uros antigos', me respondeu. ${ }^{6}$ Então lhe disse: 'Mas você ainda não sabe que a genética demonstrou que os Uros sim são Uros de verdade?' O guia ficou calado e depois de um tempo disse: 'Bem, na verdade é assim que na faculdade ${ }^{7}$ nos ensinam a falar sobre os Uros"”.

Essa anedota ilustra não só a que ponto a contestação da identidade dos Uros tornou-se institucionalizada, mas também o poder

\footnotetext{
5 Comunicação pessoal (setembro de 2010).

6 Essa resposta também recebi frequentemente nas vezes que perguntei aos guias em que baseavam suas afirmações de que os Uros não são Uros.

7 No Peru, guia turístico é uma profissão protegida por lei. Em Puno, só é permitido trabalhar como guia com diplomas dos cursos de turismo da Universidad Nacional del Altiplano e de dois institutos privados de ensino superior.
} 
potencial da genética de interferir nesse debate sobre a identidade deles e de desestabilizar o discurso dominante.

Esse quadro permite explorar algumas perguntas-chave que têm preocupado tanto geneticistas quanto antropólogos. Como o conhecimento genético é recebido pelas populações estudadas? Como este se entrelaça com políticas de identidade e lutas políticas? E como, de maneira mais geral, a genética se articula com registros sociais? (Ver em particular Brodwin, 2002; Goodman, Heath \& Lindee, 2003; Koenig, Lee \& Richardson, 2008; Palsson, 2008; Santos, 2002; Wade, 2007.) Este texto visa contribuir com respostas a tais perguntas através da interpretação e contextualização do evento etnográfico acima descrito. Obviamente, a explicação mais simples da efusão entre geneticistas e autoridades dos Uros é que as definições de ambos os lados coincidiram. Se não tivessem coincidido, a recepção dos resultados por parte dos Uros certamente teria sido muito menos calorosa. Aqui, contudo, gostaria de ir além do óbvio e analisar por que essa coincidência se tornou importante e o que isso revela sobre a relação entre a genética, as populações que ela pesquisa e os processos políticos nos quais estas estão imersas.

É importante ressaltar que o objetivo deste trabalho não é avaliar se os Uros são "Uros de verdade", mas analisar como essa pergunta se tornou relevante nesse contexto específico. Portanto não visa ressuscitar o intenso debate que foi travado dentro da antropologia durante os anos 1990 sobre a "invenção da tradição" e a autenticidade das identidades étnicas (ver, em particular: Hanson, 1989; Hobsbawm \& Ranger, 1983; Sahlins, 1993; 1999; Thomas, 1992). Contudo, se interrogativas do tipo "são os Uros realmente Uros?" hoje em dia são geralmente descartadas como perguntas teóricas e analíticas a serem respondidas através da etnografia, elas continuam relevantes como questões etnográficas dentro de um campo social e político no qual populações indígenas recebem fortes incentivos para a produção de identidades essencializadas. O enfoque aqui será, portanto, sobre as 
políticas conceituais travadas em torno da identidade dos Uros. ${ }^{8}$ Vale também ressaltar que este texto não visa interferir no debate sobre a legitimidade da pesquisa genética com populações humanas, mas contribuir para um entendimento maior das condições sociais que possam levar à aceitação ou rejeição desse tipo de pesquisa por parte das populações que constituem seu objeto.

Em continuação, este texto apresentará os Uros de hoje em dia e discutirá quem foram os Urus pré-colombianos. Depois, analisará os diferentes registros acionados para estabelecer ou negar a continuidade entre uns e outros. Em seguida, abordará a importância para os Uros da afirmação de uma identidade étnica diferenciada, assim como a dialética entre essa afirmação e a negação dessa identidade por parte dos adversários políticos deles. Isso será seguido por uma análise do que o material apresentado aqui revela sobre a genética e a sua relação com processos e registros sociais. Finalmente, o capítulo concluirá com uma discussão preliminar das consequências sociais da incorporação do conhecimento genético dentro do debate sobre a identidade dos Uros.

\section{Os Uros hoje em dia}

Nas suas autorrepresentações étnicas os Uros costumam se definir como o "povo do lago" - ou "Qot Suñis", na denominação que apropriaram da língua original Uru. E nada poderia ser mais apropriado. A vida deles está intimamente ligada ao lago e seus recursos. Cerca de $60 \%$ da população está assentada em ilhas flutuantes nos vastos campos de junco - totorales na denominação local - da baía de Puno, ${ }^{9}$

$8 \mathrm{Na}$ área de pesquisa, políticas conceituais similares estão sendo travadas também em torno do próprio conceito de "indígena". Tendo mudado de classificação de "índio" para "campesino" durante a segunda parte do século XX, as populações do Altiplano Andino voltaram a se apropriar de identificações étnicas como "indígena" a partir dos anos 1990. Contudo, princípios de representação baseados na classe e na etnia continuam a coexistir. Além disso, certos setores abandonaram o conceito "indígena" a favor da categoria "originário". Se neste trabalho se emprega o conceito indígena, é devido ao fato de que na área de pesquisa a grande maioria das pessoas se autodefinia como tal.

9 Esses campos de junco têm uma dimensão de aproximadamente 30 mil hectares. 
o restante morando em terra firme no povoado de Chulluni. Essas ilhas artificiais são feitas de plataformas de juncos e suas raízes que se desprendem do fundo do lago em épocas de chuva quando o nível das águas sobe. No lugar de maior concentração de ilhas flutuantes o rio Huili, um rio natural que percorre os campos de junco, a meia hora de barco de Puno - há hoje em torno de 60 ilhas de tamanho variável, com uma ilha típica contando entre três e oito famílias, e medindo uns 20 por 30 metros.

A economia dos Uros está fortemente ligada ao uso dos recursos aquáticos, em particular através da pesca, da caça de aves e da coleta de ovos. Os juncos servem como material de base para a construção e manutenção das ilhas, das casas e de suas balsas, para a produção de artesanato para o turismo, e às vezes até como alimento. Hoje em dia um número cada vez maior dos Uros encontra seu sustento numa vasta indústria turística centrada nas ilhas flutuantes. Esse habitat fora do comum tornou os Uros um ícone nacional e segundo destino turístico mais importante do Peru depois de Machu Picchu. Devido à sua proximidade geográfica e sua ampla inserção no mercado turístico, a população dos Uros tem uma considerável articulação econômica e política com a cidade de Puno. A maioria dos Uros mais jovens tem cursado o segundo grau em escolas de Puno e Chulluni, e uma parcela deles inclusive nível superior, sobretudo na área de turismo. Contudo, práticas matrimoniais continuam predominantemente endógamas.

O habitat das ilhas flutuantes também tem produzido uma sociabilidade muito particular entre os Uros. A mobilidade territorial é uma característica central de sua vida social. Como as ilhas são flutuantes, elas são relativamente fáceis de mover. O nível do lago Titicaca é sujeito a flutuações importantes, não só entre a época de chuva e a estação seca, mas também entre ciclos mais longos de secas e inundações. Às vezes os campos de junco secam e se tornam terra firme, em outros momentos ficam inteiramente submersos. Portanto, dependendo do nível do lago, partes diferentes dos campos de junco 
são mais adequada

Em consequência, historicamente surgimento do turismo terentes partes dos campos de junco. O cesso: desde os anos 1970 contribuído fortemente com esse proflutuantes dependen 1970 houve um movimento constante de ilhas

Outra característica- mudanças nas principais rotas turísticas. dade social. A estrutura chave da vida nas ilhas flutuantes é a flexibilides em termos de moldar a vouco sólida das ilhas abre possibilidaquem mora em terra far a vida social de formas inimagináveis para que passa além das possibido numa ilha explode um conflito comum é a separação: pedaços, e cada parte toma uma serra se corta a ilha em diferentes ilhas também são usa próprio rumo. A fissão e a fusão de 48 horas na escola um guarda-florestal da reserva refém durante inquérito contra várias autha Tribuna, o Ministério Público abriu um vidos no processo, os autoridades dos Uros. Para evitar serem envola ilha deles, dar o outro lado do novos às duas partes e remeridiram separ à ilha Tribs dissolvido para inspecionar o lugar do cue uma delegação veio sibilidades para projetos centuantes também abre importantes pos1990, vem ocorrendo um prongenharia social. Desde o final dos anos como parte de estratégias comerciais gradual fragmentação das ilhas de ingressos turísticos. Grupos de fisando a maior concentração a guias turísticos, juntos com de famílias com acesso privilegiado comissões pelo dinheiro gám próprios guias que recebem delas ração de ilhas em unidades casto pelos turistas, têm promovido a sepados ingressos. Pressionadas pela vez menores para evitar a dispersão Uros tentaram em várias ocasiões impor a unificação das ilhas em
ildos 
unidades maiores, para assim garantir uma distribuição maior dos ingressos. Inicialmente exitosas, essas iniciativas sempre acabaram sendo revertidas quando diminuía a pressão politica. Portanto, devido a esses processos a vida social fissão e fusão constante de ilhas.

\section{Os Urus pré-colombianos}

Na época da Conquista, os Urus constituíam aproximadamente $25 \%$ da população do sistema aquático Titicaca, que abrange desde os rios afluentes ao noroeste do lago até o sat centro-oeste da atual Bolívia. Essa percentagem se tornava significativamente mais alta na baía de Puno (36\%), com algumas áreas que
tinham uma população inteiramente Uru (Waachtel, Urus - de provável origem amazônica - são geralmente reconhecidos pelos historiadores como o primeiro grupo étnico a ter povoado os Andes (Wachtel, 1990). Inclusive, na cosmologia Aymara eles são considerados remanescentes de uma época pre-humana que precede ao nascimento do sol (Bouysse-Cassagne, 1992; Bouysse-Cassagne
\& Harris, 1987).

Originalmente, a população Uru tinha uma existência híbrida entre os espaços aquáticos e a terra firme, com uma economia que combinava a agricultura com o uso dos recursos aquáticos. Em decorrência das invasões sucessivas por grupos Aymaras e pelos Incas, uma proporção cada vez maior ficou confinada a uma vida em ilhas flutuantes no meio dos campos de junco, sem acesso a terras próprias. O caráter labiríntico dos campos de junco lhes permitia escapar ao controle dos novos grupos dominan relativa. Os Urus que permantes e manter uma autonomia de mão de obra aos caciques véspera da Conquista, os Uues Aymaras. No mundo social andino, na inclusive pagando os tributos eram uma população de status inferior, inca. Na maioria, mantinhos mais baixos à administração do império 
idiomas próprios, geralmente denominados como uruquilla e pukina pelos cronistas. Portanto, na época pré-colombiana a categoria Uru não era unicamente étnica, mas evidenciava um entrelaçamento entre pertencimento étnico, especialização econômica e estratificação social (Salazar, Callisaya \& Ortiz, 2003; Wachtel, 1990).

Hoje em dia, além dos Uros da baía de Puno, só permanecem três outros grupos que se identificam como Urus, todos na Bolívia: os Chipayas do salar de Coipasa (com uma população de aproximadamente 2000 pessoas), os Moratos do lago Poopó (500 pessoas) e os Iruhitos da laguna Desaguadero (150 pessoas). Contrariamente aos Uros de Puno, eles são amplamente reconhecidos como Urus "de verdade" e foram objeto de um número considerável de estudos antropológicos, linguísticos e etno-históricos. ${ }^{10}$ Os Chipayas e parte da população dos Iruhitos ainda mantêm a língua própria. ${ }^{11}$ Nas três comunidades o uso dos recursos aquáticos permanece central na vida cotidiana. Contudo, nenhum desses Urus bolivianos vive atualmente em ilhas flutuantes; os últimos a serem sedentarizados foram os Moratos nos anos 1940 (Wachtel, 1990).

\section{Registros de continuidade e ruptura}

Ao centro do debate sobre a identidade dos Uros da baía de Puno está a pergunta se existe ou não uma continuidade entre eles e os Urus pré-colombianos. Nesse debate, diferentes registros - socioculturais, linguísticos, etno-históricos e genéticos - são acionados por uma variedade de atores para estabelecer ou negar essa continuidade.

Um primeiro registro sociocultural de continuidade é usado pelos próprios Uros, para quem a característica definidora do que é ser Uro consiste no estilo de vida nas ilhas flutuantes e a ligação íntima com o

\footnotetext{
10 Um levantamento bibliográfico feito em 2003 pelo Museo de Etnografía y Folclore de
La Paz revelou mais de 170 publicações sobre os Urus da Bolívia (Vladimir Salazar,
comunicação pessoal).

1 Essa língua é hoje referida como uchumataqu.
} 
lago e seus recursos. Nas suas autorrepresentações e no seu discurso político, eles frequentemente estabelecem uma conexão direta com os Urus pré-colombianos que viviam num mesmo habitat e baseavam seu sustento na caça, na pesca e na coleta. Um pronunciamento de 2005, por exemplo, afirma o seguinte:

Somos os primeiros a habitar os Andes e a viver no lago Titicaca [...]. Somos parte do lago e ele é parte de nós, os campos de junco são o nosso lar, o nosso refúgio, as aves são os nossos irmãos e nossos antepassados ainda vivem nele [o lago]. Vivemos dos recursos do lago Titicaca como os nossos antepassados, porque ser Uro [...] para nós significa ser caçador e pescador por excelência. ${ }^{12}$

Em contraste, outro registro - também de natureza sociocultural - estabelece uma enfática descontinuidade entre os Urus antigos e a população atual das ilhas flutuantes. A visão mais difundida na cidade de Puno é que os Urus originais se extinguiram há muito tempo e que a população atual das ilhas descende de Aymaras que se estabeleceram nos campos de junco entre o final do século XIX e a década de 1940. Contudo, histórias orais coletadas pelo antropólogo Henry Flores ${ }^{13}$ e por mim mesmo estabelecem a presença dos Uros nos campos de junco da baía de Puno remontando até pelos menos a Guerra do' Pacífico (1879-1884). ${ }^{14}$

Quando visitei o departamento de antropologia da Universidad Nacional del Altiplano em Puno pela primeira vez em 2004, fiquei surpreso ao descobrir que - além de uma pesquisa sobre a tecnologia das ilhas flutuantes - nenhum estudo tinha sido realizado sobre os Uros. Perguntado sobre a razão dessa ausência, um dos principais

12 Esse pronunciamento foi escrito na ocasião do lançamento de um livro sobre o primeiro encontro oficial com os grupos Urus da Bolívia, e assinado pelo então prefeito Juan Coyla e seu sucessor Júlio Vilca.

13 Comunicação pessoal (abril de 2006).

14 Além disso, um número considerável de habitantes aimarás da península de Chucuito reclama ser descendente da população das ilhas flutuantes, tendo migrado à terra durante a seca dos anos 1940. Isso inverte o quadro. 
antropólogos do departamento respondeu: "Não estamos interessados nos Uros porque perderam a identidade deles". Exemplos frequentes que ouvi em Puno ao longo dos anos para atestar essa "falta de identidade" incluem o fato de os Uros só terem reintroduzido o uso de roupas típicas há aproximadamente dez anos, motivados por interesses turísticos; de eles não terem uma vida cerimonial rica; e, em geral, de serem muito "modernos", com aparelhos de DVD em casa e um poder aquisitivo mais alto que seus pares nas comunidades da ribeira. Em outras palavras, por eles não possuírem os sinais diacríticos aos quais populações indígenas precisam corresponder para serem consideradas "autênticas" (ver Conklin, 1997; Rosaldo, 1988).

Outro registro que é acionado para negar uma continuidade entre Uros presentes e passados é o da linguística. Os Uros da baía de Puno falam hoje em dia Aymara. Esse argumento adquire um peso importante, dada a tendência nos Andes de equiparar identidade étnica com língua. Por exemplo, um indivíduo é identificado como Quéchua ou Aymara segundo a língua que ele ou ela fala. Nesse registro - bem como no registro sociocultural anterior - os grupos Urus da Bolívia frequentemente servem como contraponto ao que seria um Uru autêntico (para maiores informações sobre a língua Uru, ver Cerrón Palomino, 2006; Rivet \& Crequit-Montfort, 1925; Torero, 1992). Contudo, há várias indicações de que na baía de Puno o desaparecimento da língua original Uru ocorreu num passado relativamente recente. Segundo Otilia Valderrama, que ofereceu cursos de alfabetização aos Uros assentados nos campos de junco durante os anos 1940, nessa época eles falavam um Aymara entrelaçado com palavras desconhecidas, que eles atribuíam à língua original deles, sugerindo que essa língua estaria num processo de transição ainda inconcluso para o Aymara. Além disso, um estudo de linguistas alemães de 1929 revela que naquele tempo na comunidade ribeirinha de Chimu - onde hoje em dia se fala Aymara - a língua dominante era o uruquilla (Torero, 1992). 
Uma descontinuidade importante ocorreu também nos sistemas classificatórios. Como revela a pesquisa etno-histórica de Nathan Wachtel (1990), a redução dramática da população Uru de 25\% do total do sistema aquático Titicaca na época da Conquista para uns poucos milhares hoje em dia não se deveu à extinção dos Urus, mas à gradual redefinição deles como Aymaras. O fator crucial nesse processo é o uso pelas autoridades coloniais dos rótulos "Uru" e "Aymara" não como categorias étnicas, mas como categorias tributárias. Devido ao fato de que os Urus tinham menor acesso a recursos econômicos vitais - principalmente terra e gado - do que os Aymaras, eles pagavam menos tributo, geralmente cerca da metade do tributo dos Aymaras. Isso, contudo, significava que eles também gozavam de menos direitos e mantinham seu status inferior da época pré-colonial. Em consequência, no momento em que indivíduos ou grupos Urus tiveram os recursos suficientes, eles optaram por pagar os mesmos tributos que os Aymaras para assim acederem ao status e aos direitos plenos correspondentes. Dessa forma eles passaram para a categoria de Aymara.

Além disso, as políticas de sedentarização dos Urus por parte das autoridades coloniais contribuíram de maneira significativa para esse processo de aymarização. As autoridades incentivaram - e, sobretudo durante as várias revoltas Urus no primeiro século e meio da colônia, frequentemente forçaram a população aquática a se estabelecer em terra firme e a se tornar agricultora, para assim tornar o controle sobre ela mais fácil. Essa política era facilitada pelo aumento da disponibilidade de terras devido à redução drástica da população andina em decorrência da Conquista. O resultado desses processos foi uma gradativa aymarização dos Urus, praticamente concluída no final do século XVII (Wachtel, 1978; 1990). Esse caso não é uma exceção: desde a colônia até ao presente, há nos Andes uma tendência à sobreposição de categorias étnicas, biológicas, sociais e econômicas (De la Cadena, 2000; 2005; Harris, 1995). 
O último registro acionado dentro do debate sobre a identidade dos Uros é o genético. Esse sim afirma uma continuidade entre passado e presente. Se as transições nos sistemas classificatórios dificultam as tentativas de estabelecer continuidades identitárias entre a época pré-colombiana e o presente, elas também abrem a possibilidade de questionar afirmações de descontinuidade desde o ponto de vista genético. A introdução de um artigo publicado por Sandoval, Fujita e colaboradores revela que foi justamente a pesquisa de Nathan Wachtel que os levou à hipótese da continuidade biológica dos Urus. Depois de mencionar o processo de aymarização analisado por Wachtel, eles argumentam que "estes antecedentes levam a pensar que os habitantes das ilhas Los Uros manteriam ainda parte do seu acervo genético proveniente dos Urus originais" (Sandoval et al. 2004: 162, tradução minha). ${ }^{15}$

A pesquisa genética de Fujita e Sandoval restabeleceu essa continuidade entre Urus pré-colombianos e a população atual dos Uros da maneira seguinte: ${ }^{16}$ fora as ilhas dos Uros, foram coletadas amostras em duas comunidades Quéchuas e uma comunidade Aymara assentadas em ilhas do lago Titicaca. A parte do genoma analisado foi o DNA mitocondrial, que se transmite integramente da mãe para os filhos e, portanto, permite identificar o ancestral mais remoto do lado materno. Considera-se que, entre as populações ameríndias, ${ }^{17}$ existem quatro haplogrupos - grupos de pessoas que têm certos marcadores ancestrais em comum - principais: A, B, C e D. Os resultados da pesquisa revelam que as duas comunidades Quéchuas e a Aymara analisadas se encontram quase integralmente dentro do haplogrupo

15 Ricardo Fujita afirma ter trabalhado desde o começo da sua pesquisa no lago Titicaca com a hipótese dos "Uros Aymarizados" (comunicação pessoal).

16 Para essa pesquisa foram usadas 28 amostras coletadas em 1998 por José Sandoval entre alunos escolares, 19 das quais numa escola das ilhas flutuantes e outras nove na escola de Chulluni, em terra firme.

17 Aqui difiro do uso do conceito indígena porque ameríndio é o conceito mais comum usado hoje em dia em publicações genéticas para se referir às populações indígenas das Américas. 
B. Em contraste, os Uros são os únicos com uma significante proporção do haplogrupo A2: 18\% (Sandoval et al. 2004: 166). Portanto, o primeiro passo na análise consistiu em estabelecer uma diferença com as populações ao redor.

O passo seguinte foi traçar essa diferença a uma origem distinta. Enquanto o haplogrupo B está associado principalmente com a área do Pacífico, os haplogrupos A, C e D se encontram de maneira predominante na região amazônica. Aymaras e Quéchuas em grande maioria possuem o haplogrupo B, sugerindo uma subida aos Andes desde a costa do Pacífico (Merriwether et al., 1996; Rodriguez-Delfin, Rubin-de-Celis \& Zago, 2001). Em contraste, para Sandoval, Fujita e colegas a presença do haplogrupo A2 entre os Uros apontaria para uma origem remota amazônica (Sandoval et al., 2004: 165-167). Eles reforçam essa hipótese se referindo a teorias baseadas em estudos linguísticos e de grupos sanguíneos que também sugerem um povoamento diferenciado dos Andes - com a primeira leva populacional subindo desde a Amazônia - e um parentesco dos Urus com os arawaks da região amazônica (ver também Greenberg, 1987; Rivet \& Crequit-Montfort, 1925; Torero, 1992). ${ }^{18}$

Essas considerações levam Sandoval, Fujita e colegas à conclusão que: "os habitantes das ilhas dos Uros conservam ainda um importante componente genético Uru (...) indo de encontro à ideia da sua extinção" (Sandoval et al., 2004, tradução minha). Em outra publicação, os autores sugerem que o resultado da pesquisa "poderia indicar maior antiguidade" dos Uros (Córdova et al., 2008: 28). Como mencionado na introdução, os primeiros resultados das análises com as amostras mais recentes coletadas no âmbito do projeto Genográfico evidenciam a existência de alelos próprios entre os Uros, o que

18 De fato, segundo Fabrício Santos - coordenador do projeto Genográfico para a América Latina -, o próximo passo na pesquisa será comparar o material genético dos Uros com o dos Arawaks e outros povos amazônicos (comunicação pessoal, agosto de 2010). 
reforçaria a ideia de uma continuidade genética. ${ }^{19}$ Segundo Ricardo Fujita, isso indicaria que "geneticamente eles sim são Uros". ${ }^{20}$

\section{A importância de ser Uro}

Uma questão central para entender a recepção que os Uros deram à pesquisa genética é o porquê da afirmação de uma identidade étnica diferenciada ter se tornado tão importante para os Uros da baía de Puno. Um primeiro fator-chave é o turismo. A atração dos Uros no mercado turístico não é só constituída pelo habitat particular deles nas ilhas flutuantes, mas também pela imagem de uma cultura milenária que oferecem. Para competir nesse mercado se tornou também de importância estratégica para os Uros se pautarem como uma cultura original e diferenciada dos vizinhos Aymaras e Quéchuas. Com o crescimento do turismo eles continuaram a reforçar essa imagem, embora - como já mencionado - ela venha sendo contestada por um segmento importante da própria indústria turística.

Desde 2001, o conflito com a reserva vem fornecendo aos Uros outro incentivo importante para a afirmação de uma identidade étnica diferenciada. ${ }^{21}$ A Reserva Nacional del Titicaca foi criada pelo governo peruano em 1978 para regular o uso dos recursos naturais dentro dos campos de junco. Com uma presença relativamente fraca na área durante as primeiras duas décadas devido à limitação de recursos, a administração da reserva se torna mais efetiva a partir de 1996, com doações do governo alemão. Embora as relações com os Uros nunca tenham sido fáceis, o conflito aberto só se instalou no ano 2001, com a tentativa da reserva de se apropriar do controle sobre os fluxos e ingressos turísticos para as ilhas flutuantes, ameaçando dessa

19 Contudo, como se trata de resultados preliminares de uma análise em andamento e como ainda não foram publicados, não podem ser tratados em maiores detalhes aqui.

20 Comunicação pessoal (setembro de 2010).

21 Se este trabalho analisa os discursos identitários e as estratégias políticas que predominam entre as autoridades dos Uros, isso não significa que o consenso entre a população seja total. Contudo, por razões de espaço não será possível discutir divisões internas ou a variedade de posições diante do conflito que existem ao nível individual. 
maneira a principal fonte de ingressos dos Uros. A resposta inicial das autoridades dos Uros foi de exigir a conversão do seu território aquático - na definição deles $11.383,75$ hectares, ou perto de $40 \%$ da área da Reserva Nacional - numa reserva comunal. Esse é um estatuto territorial dentro do sistema peruano de áreas protegidas que foi concebido para a gestão direta por parte de populações indígenas. Depois de expulsar os agentes da Reserva Nacional do seu posto de controle principal dentro dos campos de junco em junho de 2002, os Uros decretaram a criação da reserva comunal e começaram a gerenciar seu território como uma área protegida, espelhado na administração da Reserva Nacional. ${ }^{22}$ Iniciaram um forte lobby para o reconhecimento oficial da reserva comunal pelo Estado, que chegou a incluir como aliados o governo regional de Puno e o próprio presidente do Peru, Alejandro Toledo. Sentindo-se ameaçadas nos seus próprios direitos territoriais pela ofensiva política dos Uros, muitas comunidades Aymaras e Quéchuas da ribeira se aliaram com a Reserva Nacional. Elas constituíram comitês de conservação em cada comunidade e formularam suas próprias reivindicações territoriais baseadas nos usos tradicionais (para análises mais detalhadas sobre o conflito em seus variados aspectos, ver Guevara-Gil, 2007; Kent, 2006; 2008; 2009; Orlove, 1991). ${ }^{23}$

Até então as sete reservas comunais existentes no Peru tinham sido criadas na região amazônica, no território de populações indígenas relativamente pequenas e isoladas. No Peru, a identidade indígena

22 Entre outras medidas, montaram uma estrutura administrativa, que incluía um chefe e dez guardas florestais; elaboraram um zoneamento ambiental e um plano de exploração turística; decretaram a proibição de caça às aves nas proximidades das ilhas flutuantes, implementada através de patrulhas frequentes e um sistema de sanções contra infratores. O cargo de chefe de reserva comunal foi ocupado por Julio Vilca, antes do seu período como prefeito.

23 Apesar do apoio político considerável que mobilizaram dentro do próprio Estado, os Uros não conseguiram o reconhecimento da reserva comunal. Quando as negociações estancaram no final de 2004 , eles mudaram de estratégia e junto com varias populações ribeirinhas exigiram a abolição da Reserva Nacional e a titulação dos campos de junco, em nome das populações locais. 
dos povos amazônicos em geral é cercada de menos ambiguidades do que no caso das populações andinas. Um obstáculo principal para a transposição da categoria reserva comunal para os Andes foi a existência de uma população Aymara e Quéchua que se contava aos milhões, e cuja identidade se encontrava num processo ainda inconcluso de transição de campesino para indígena. ${ }^{24}$ Portanto, para demandar uma reserva comunal foi de importância fundamental para os Uros afirmarem uma identidade que fosse indígena sem ambiguidade, e que se diferenciasse claramente dos Aymaras e Quéchuas ao seu redor. Em um pronunciamento datado de 5 de dezembro 2005 , afirmam: "Somos o povo mais antigo do que qualquer povo dos Andes, antes dos Aymaras, antes dos incas. (...) nós seguimos nos considerando pescadores, caçadores e coletores de ovos".

Reivindicar maior antiguidade do que os Aymaras e Quéchuas também servia para afirmar retoricamente direitos que antecedem os dos seus oponentes nas comunidades da ribeira. Além disso, referências à identidade clássica dos Urus como caçadores, pescadores e coletores também lhes permitiram estabelecer conexões com uma categoria de população - caçadores e coletores - que dentro do imaginário ambiental é concebida como interagindo de maneira mais harmônica com o meio ambiente, assim construindo simbolicamente suas qualificações para o manejo de um território redefinido em termos ambientais (ver Ramos, 1998; Redford, 1990; Wade, 1997). Finalmente, a sua imagem emblemática como ícone nacional e a visibilidade pública que isso lhes conferiu permitiu aos Uros conquistarem apoio político até nos mais altos escalões do governo central.

A resposta por parte de atores ligados à Reserva Nacional e seus aliados foi precisamente a negação dessa identidade diferenciada dos Uros, reforçando de maneira substancial as contestações a essa identidade que já circularam em Puno. Nas suas representações,

24 Ver também a nota 8. 
eles atacaram dois pontos centrais na construção dos Uros de uma continuidade com o passado: a relação íntima deles com o lago Titicaca e a ocupação do território. Um discurso que chegou a se escutar frequentemente em Puno é que "os Uros não moram nas ilhas flutuantes. Eles são Aymaras que vivem em terra firme e toda manhã remam até as ilhas para brincar de Uros e enganar o turista".

A adoção desse discurso pela Reserva Nacional coincidiu com a intensificação do conflito com os Uros na primeira metade de $2002 .{ }^{25}$ Até então, as representações oficiais que a reserva oferecia dos Uros tendiam a enfatizar a sua distinção étnica. O primeiro plano de gestão da Reserva Nacional, por exemplo, afirma que os Uros "conservaram, sem dúvida, parte das tradições e costumes do antigo povo Uros" (Cepid, 1979: 26, tradução minha). E, nos informes anuais que produziu durante os anos 1990, a "cultura milenar dos Uros" figurava regularmente como um dos "atrativos principais" da reserva. A mudança de discurso parece, portanto, ser estreitamente relacionada à dinâmica do conflito. ${ }^{26}$ Essa negação da identidade diferenciada dos Uros não foi só propagada pelos agentes da própria Reserva Nacional, mas também com particular força pelos seus aliados Aymaras e Quéchuas da ribeira no seu questionamento das reivindicações feitas pelos Uros de direitos que precederiam aos deles.

A reação dos Uros foi afirmar com ainda mais força a identidade deles como Uros. Um elemento-chave nessa estratégia foi a articulação com os três grupos da Bolívia - Chipayas, Moratos e Iruhitos - que são amplamente reconhecidos como Urus. Em março

25 Vários colaboradores próximos à reserva afirmam que a iniciativa foi tomada pelo então chefe de reserva Carlos Panduro, cuja gestão entre fevereiro e junho de 2002 foi particularmente marcada por confrontos com os Uros.

26 Essa hipótese é reforçada por outra mudança simultânea de discurso. Antes do conflito, os documentos oficiais da Reserva Nacional costumavam representar os Uros como uma população que vivia em relativa harmonia com o meio ambiente. Em contraste, a partir de 2002 passou a redefini-los como poluidores e predadores ambientais, contrariando assim os esforços dos Uros de construir uma imagem étnica ambientalizada. Inclusive, em 2005 as principais autoridades dos Uros enfrentaram um processo penal por infrações às leis ambientais, iniciado por uma denúncia feita pela Reserva Nacional e só arquivado em 2008. 
de 2004 foi organizado o primeiro encontro com representantes dos quatro grupos da comunidade Iruhito na Bolívia. ${ }^{27}$ Esse evento foi propagado como "o primeiro encontro da Nação Uros em 500 anos". Durante uma semana os participantes compararam suas práticas sociais e culturais como a pesca e a caça, seus mitos e sua língua, assim como refletiram sobre uma identidade coletiva e possíveis estratégias políticas conjuntas. $\mathrm{O}$ encontro culminou na promulgação da nova fundação da "Nación Qhas Qot Suñi Uros". 28

Enquanto os Uros da baía de Puno tiveram pouca participação ativa na organização do primeiro encontro, ${ }^{29}$ eles tomaram a frente na consolidação dessa articulação. O próprio Julio Vilca - prefeito na época da visita dos geneticistas, e eleito "autoridade originária" em 2004 para representá-los na Nação Uros - foi um dos catalisadores principais desse processo. Dentro da própria comunidade foi ele quem mais enfatizou a importância de recuperar elementos identitários Uros. Ele coordenou a organização do segundo encontro da Nação Uros em novembro de 2005 nas ilhas flutuantes. Um terceiro encontro foi organizado em Chipaya em 2007 e um quarto em 2010, com várias reuniões menores de autoridades nos intervalos. O interesse principal dos Uros da baía de Puno nessa articulação foi o de se associar publicamente a grupos amplamente reconhecidos como Urus - com uma longa trajetória de validação identitária através de estudos antropológicos, linguísticos e etno-históricos - e que pudessem conferir legitimidade

27 Os Uros da baía de Puno enviaram 20 representantes.

28 Esse termo resultou de um compromisso entre os vários grupos e suas autodefinições. Enquanto os Iruhitos e Moratos se definiam como "Qot Suñi" - o povo do lago - os Chipayas usavam o termo "Qhas Suñi", o povo das águas. Os Uros da baía de Puno insistiram em manter o termo "Uro", dada a sua importância na luta deles e como marca estabelecida

29 A organização desse encontro foi coordenada pelo antropólogo Boliviano Manuel Rojas, que tinha uma longa trajetória de pesquisa entre os Iruhitos, e financiado por Íbis, uma $\mathrm{Na}$ Bolívia, a articulação forte presença na região andina na temática da política indígena. em vários anos a incorporac̃ão Chipayas, Moratos e Iruhitos numa "Nação Urus" antecede incluídos por iniciativa de dan Uros da baía de Puno ao processo. Estes últimos foram 
às próprias reivindicações étnicas. Como ficou evidente durante o encontro em 2004, o interesse dos Urus da Bolívia na colaboração estava relacionado sobretudo à conservação pelos Uros da baía de Puno de uma vida nas ilhas flutuantes, suas experiências com o turismo e suas experiências exitosas no campo da mobilização política.

O que sobressai nessas negociações em torno da identidade dos Uros é uma dialética constante de negação e reafirmação. Quanto mais ela é contestada pelos seus adversários políticos, quanto mais importante se torna para as lideranças dos Uros reafirmar e encontrar sustento para esta identidade diferenciada. Assim a questão se os Uros são "Uros de verdade" se tornou uma pergunta cada vez mais central no conflito com a Reserva Nacional.

\section{A genética, processos sociais e políticas conceituais}

É nesse contexto de intensas lutas políticas travadas em torno da identidade dos Uros que a pesquisa genética se insere. Como já revelado na introdução pela primeira reação do prefeito Julio Vilca aos resultados da pesquisa, para as autoridades dos Uros, a importância da colaboração com os geneticistas se encontra na possibilidade de uma validação científica de reivindicações de distinção étnica e de antiguidade, que até então não conseguiram ser aceitas pela opinião pública e acadêmica através de outros meios.

Esse interesse na genética como um potencial recurso político ficou evidente desde o primeiro encontro com a equipe do projeto Genográfico em 2007, quando foram coletadas as amostras. A aproximação entre o Ricardo Fujita e as autoridades dos Uros foi mediada através de Henry Flores, um dos raros antropólogos de Puno que apoiavam as reivindicações étnicas dos Uros e o único a ter feito pesquisa nas ilhas flutuantes nos últimos 15 anos, em 2005. ${ }^{30}$ Durante

30 Essa pesquisa enfocou os mitos dos Uros. Em 2004, depois da primeira publicação de Sandoval, Fujita e colaboradores sobre os Uros, Henry convidou Fujita a proferir uma palestra. Esse convite não se concretizou por falta de recursos. 
a apresentação do projeto nas ilhas flutuantes pela equipe do projeto Genográfico, o prefeito Julio teve uma intervenção decisiva na superação da resistência inicial da população das ilhas em participar, com o seguinte discurso: "Sempre nos perguntamos se somos Uros ou não. Então vamos lá, para que nos digam de uma vez por todas se somos Uros ou não! Demonstrar que somos Uros vai nos servir na nossa luta. Eu vou primeiro!".

Depois de ter sua amostra coletada, Julio instou os cinco vereadores do município a seguirem seu exemplo. ${ }^{31}$ Depois deles, em torno de 15 outros participantes da reunião ofereceram suas amostras. $\mathrm{Na}$ visita seguinte, a equipe do projeto Genográfico percorreu as ilhas flutuantes em companhia de vários vereadores para coletar uma amostragem representativa dos diversos troncos familiares dos Uros. Os vereadores que os acompanharam se encarregaram de convencer os indivíduos selecionados a participar. No total, foram coletadas entre 40 e 50 amostras. Por orientação dos geneticistas, os participantes foram selecionados unicamente entre a população das ilhas. Por sugestão de Henry Flores foram escolhidas preferencialmente pessoas mais idosas, segundo ele "porque entre os mais jovens já há maior contribuição Aymara, os idosos são mais Uros". Os critérios de seleção, portanto, revelam uma predisposição por parte de todos os envolvidos na coleta a direcioná-la para um segmento da população assumido como biologicamente mais autêntico.

31 Mesmo com esse terreno fértil para a aceitabilidade social da genética, superar a relutância da população Uro de participar da pesquisa exigiu um trabalho considerável de mediação. Além dos incentivos dados pelas próprias autoridades, este incluiu um discurso de Henry Flores, que enfatizou a importância de reportagens anteriores da National Geographic para o desenvolvimento do turismo nas ilhas. Sugeriu que participar nesse projeto de genética patrocinada pela mesma sociedade poderia contribuir a um incremento no número de visitantes. Também teve uma participação importante o integrante da equipe genética José Sandoval, que tinha coletado as primeiras amostras em 1998. Ele é um aimará oriundo de uma comunidade ribeirinha do lago Titicaca. Discursou para os Uros em Aymara e teve a sua própria amostra coletada para dar o exemplo. Ocorreu, portanto, uma tripla mediação por parte respectivamente de um geneticista da região que era indígena e falava a mesma língua, um antropólogo local que já tinha construído uma relação de relativa confiança com os Uros e, finalmente, as próprias autoridades principais. 
Para entender as condições de aceitabilidade social da genética, o menor interesse por parte dos grupos Urus da Bolívia de participar com o projeto Genográfico se torna revelador. ${ }^{32}$ Os Chipayas, Moratos e Iruhitos já são amplamente reconhecidos na Bolívia como Urus, e todos têm seus direitos a território garantidos: como "Nación Urus-Chipaya" e como município no caso dos Chipayas; e como comunidade no caso dos Moratos e Iruhitos. Apesar de contar também com a participação de um antropólogo próximo aos Urus - Manuel Rojas, principal articulador dos dois primeiros encontros da Nação Uros - durante a viagem às três comunidades em 2009 foi coletado um número de amostras significativamente menor - 15 no total - do que entre os Uros da baía de Puno. Segundo a geneticista boliviana Cinthia Cuellar, que participou da coleta das amostras, uma preocupação principal dos Urus bolivianos em relação à pesquisa genética foi a seguinte: "Eles tinham medo de que se disséssemos que eles não eram Urus, eles iriam perder o direito ao território deles". Portanto, se os Uros da baía de Puno não tinham pouco ou nada a perder a esse respeito, os Urus da Bolívia interpretavam a pesquisa genética como um fator de risco em relação às suas conquistas de direitos políticos e de reconhecimento identitário.

Através das suas pesquisas com populações indígenas, os geneticistas se tornam participantes ativos de políticas conceituais travadas em torno das identidades dessas populações. Os Uros da baía de Puno são atualmente o centro de um debate entre diversos registros disponíveis para definir identidades: sociais, culturais, linguísticos, políticos e biológicos. Alguns destes se contradizem, outros se reforçam. Ricardo Fujita e outros geneticistas se posicionam e concorrem dentro desse debate. Eles têm usado a etno-história para contestar o registro linguístico e revalidar a autoclassificação dos Uros. Nas suas

32 O componente boliviano do projeto Genográfico é coordenado pela professora Susana Revollo, da Universidad Nacional San Andrés de La Paz. Foram coletadas amostras entre os três grupos Urus em dezembro de 2009. Os resultados das análises ainda não estavam disponíveis na hora da escrita deste texto. 
publicações, a genética é construída como sendo mais confiável do que a linguística, por esta última só representar referências culturais (Sandoval et al., 2004: 167). O interessante nesse caso é que a análise genética não avalia uma afirmação positiva de uma identidade diferenciada, mas ela responde a uma contestação desta. Se no primeiro caso uma frequência de $18 \%$ poderia parecer pouco para validar uma identidade, ela se torna altamente significativa para invalidar uma negação. Naturalmente, o que é ser Uros tem sentidos múltiplos e contraditórios em diferentes registros. Embora geneticistas e Uros concordem na afirmação positiva de uma identidade diferenciada, ser "o povo do lago" ainda é algo muito distinto de "ter o haplogrupo A2".

Essas políticas conceituais são entrelaçadas com lutas políticas mais tangíveis em torno do acesso a territórios e a recursos valiosos. A pergunta se os Uros são Uros de verdade se converteu paralelamente em um debate político e um debate acadêmico. Nesse encontro entre os geneticistas do projeto Genográfico e as autoridades dos Uros, os dois debates se cruzaram. As respostas à pergunta central sobre a identidade dos Uros - sendo ambas positivas - se entrelaçaram, abrindo um novo campo de possibilidades, seja na esfera política para os Uros, seja no domínio acadêmico para os geneticistas, já que a rejeição por parte de populações indígenas, seus representantes ou comitês de ética tem sido, em vários países, um dos principais obstáculos à execução do projeto Genográfico.

A inserção da pesquisa genética dentro do campo das políticas conceituais em torno da identidade dos Uros revela uma constante interação entre repertórios biológicos e sociais, criando uma espécie de loop. De um lado, os geneticistas afirmam que os Uros são geneticamente muito mais Uros do que se pensava. Contudo, de outro lado não teria sido possível levantar essa questão sem uma forte afirmação da identidade própria por parte dos Uros, uma contestação política e acadêmica dessa identidade, e finalmente o lugar central dos Uros no imaginário nacional. Portanto, enquanto a genética faz afirmações 
sobre o mundo social, as categorias (biológicas) que emprega são parcialmente pré-estruturadas por ideias provenientes desse mundo social. Os resultados da pesquisa genética são traduzidos em categorias sociais, associando certos haplogrupos com certas populações, por exemplo os antigos Urus com o haplogrupo A2. Já saindo do campo genético, a afirmação de que " $18 \%$ dos Uros têm o haplogrupo A2 no DNA mitocondrial" é traduzida durante a discussão esboçada na introdução em "a genética diz que os Uros são Uros de verdade". Como a reação do guia turístico durante essa discussão demonstra, o conhecimento genético tem o poder de transformar ideias e categorias sociais, fechando assim o loop. Esse processo implica uma multiplicidade de traduções e articulações. Embora muito distintos um do outro, "o povo do lago" e o "haplogrupo A2" começam a se equiparar dentro de um campo conceitual compartilhado. Eles se entrelaçam na figura do Uro, que assim se torna um híbrido com o potencial de articular distintos registros sociais e biológicos.

\section{Consequências sociais}

Embora a incorporação recente da genética dentro do campo político local torne difícil identificar desde já as suas consequências sociais, é possível indicar algumas direções preliminares para a análise, bem como levantar um número de perguntas relevantes para serem exploradas em pesquisa futura. Os primeiros encontros entre a equipe do projeto Genográfico e as autoridades dos Uros revelaram uma clara intenção destes de usar a genética como um recurso no conflito com a Reserva Nacional. Contudo, até setembro de 2010 esse uso ainda não se tinha concretizado na prática. Uma parte importante da explicação é que desde a divulgação dos resultados genéticos houve um período de calma prolongada no conflito, com os dois lados evitando os confrontos. Não houve da parte dos Uros nenhuma mobilização ou pronunciamento político em que reivindicações identitárias precisassem ser acionadas. 
No caso de uma escalada futura do conflito, seria necessário analisar se os Uros optam ou não por usar o argumento genético, quais considerações os levam à sua decisão, e através de quais debates internos essa decisão é tomada. Outras perguntas a serem exploradas são quais efeitos terá a incorporação da genética sobre a dinâmica do conflito? Quem dá voz de autoridade à genética dentro do debate político, e quem tenta mantê-la de fora? E nessa dialética contínua entre afirmação e negação, qual será a resposta por parte da Reserva Nacional e seus aliados?

O que pode se tornar no futuro um fator central na incorporação da genética nesse debate é o resultado das análises do DNA das comunidades Aymara e Quéchua da ribeira da baía de Puno. Além de se reunir com os Uros, em novembro de 2008 a equipe do projeto Genográfico também coletou amostras de participantes de várias comunidades ribeirinhas. Algumas dezenas de amostras adicionais foram coletadas entre as autoridades dos comitês de conservação aliados à Reserva Nacional durante a sua reunião mensal em Puno. Já que na época da Conquista a baía de Puno inteira tinha uma população Uru importante, não será de surpreender se as análises revelarem entre as populações contemporâneas da baía de Puno a existência de uma proporção significativa das mesmas características genéticas que se destacam entre os Uros. Como Ricardo Fujita explica: "sempre trabalhei com a hipótese que as populações do lago Titicaca são Uros Aymarizados. Por causa dos estudos históricos se sabe que muitos Uros foram a viver em terra e assim foram Aymarizados, mas geneticamente continuam Uros". ${ }^{33}$

De fato, os resultados preliminares da análise das amostras coletadas entre as populações ribeirinhas da baía de Puno revelam que algumas delas também possuem os alelos próprios identificados entre os Uros, o que segundo Fujita significaria que elas igualmente seriam de descendência Uru.

33 Comunicação pessoal (setembro de 2010). 
Isso pode ter consequências importantes para as políticas conceituais em torno da identidade dos Uros. Para estes, no conflito com a Reserva Nacional, se tornou de importância fundamental poder afirmar uma identidade que os diferencia das populações ao redor. A estratégia dos seus oponentes foi justamente a de negar e diluir essa diferença. Agora, se a genética fornecesse aos Aymaras e Quéchuas da ribeira argumentos para afirmar que "somos todos Uros", isso desestabilizaria as políticas de identidade dos Uros tanto quanto dizer que "os Uros não são Uros de verdade".

Embora os próprios Uros ainda não tenham feito muito uso de argumentos baseados na genética, em setembro de 2010 já era possível notar um efeito considerável da pesquisa genética sobre a opinião pública em Puno com respeito à identidade dos Uros. Em particular, argumentos genéticos parecem ter silenciado o discurso que os Uros não são Uros. Um pequeno número de intelectuais de Puno que já oferecia apoio público às reivindicações identitárias dos Uros incorporou o resultado das pesquisas genéticas nos argumentos deles. Estes incluem Juan Palao, um antropólogo independente que já desde os anos 1990 usava argumentos biológicos para afirmar uma continuidade entre Uros antigos e contemporâneos; ${ }^{34}$ o antropólogo Henry Flores, que pouco depois de ingressar como professor temporário na Universidad Nacional del Altiplano organizou um seminário para discutir a identidade dos Uros; e Anita Pino, do Centro Cultural Casa del Corregidor.

Eles tiveram um papel significativo na difusão em Puno das pesquisas genéticas sobre os Uros através de sua participação em palestras, seminários, debates ou conversas mais informais. Se eles não haviam conseguido convencer a opinião pública através de outros discursos, o argumento genético a favor dos Uros foi largamente aceito. A maneira em que foi incorporada a pesquisa de Fujita e

34 Em particular, antes de incorporar a pesquisa genética ele se referia à pesquisa com grupos sanguíneos feita por Paul Rivet nos anos 1920 entre os Uros, que indicava uma familiaridade entre eles e os Arawaks. 
Sandoval dentro do debate sobre a identidade dos Uros sugere que os participantes não indígenas concebem a genética como uma verdade quase absoluta, um árbitro em última instância das identidades em jogo. Quando perguntei a Anita Pino por que, segundo ela, a genética tinha conseguido convencer uma opinião pública sensível a nenhum outro argumento, ela respondeu: "Eles não têm outra saída. A genética já é algo que eles não podem refutar com a sua ideologia. Se a genética diz que é assim, então é assim".

O efeito foi particularmente notável no âmbito da indústria turística. Juan Palao é agora convidado pelos cursos de formação de guias turísticos para oferecer capacitações sobre os Uros, durante as quais ele discute a pesquisa de Ricardo Fujita para argumentar que os Uros são geneticamente diferentes dos Aymaras e Quéchuas. Isso reverte a institucionalização do discurso que negava uma identidade diferenciada aos Uros. Enquanto durante minhas estadias nas ilhas flutuantes entre 2003 e 2006 era muito comum ouvir guias turísticos argumentarem que "os Uros não são Uros", durante uma visita de duas semanas em setembro de 2010 não ouvi esse argumento uma só vez. Inclusive, duas das principais agências turísticas de Puno - Titicaca Tour e Titicaca Peru - usam a pesquisa de Fujita e Sandoval para estabelecer uma continuidade direta entre os Urus antigos e a população atual das ilhas flutuantes. Nas informações que brindam sobre os Uros nos seus respectivos websites, elas afirmam que: "Embora muitos autores afirmem que o grupo étnico dos Uros foi extinto, num estudo recente da estrutura genética dos Quéchuas e Aymaras do lago Titicaca foi encontrado que os Uros de hoje preservam ainda uma parte dos genes originais de seus ancestrais (PhD Fujita y Sandoval). Hoje graças aos Uros que ainda vivem nestas ilhas, podemos imaginar e apreciar a forma de vida de um grupo étnico tão antigo". ${ }^{35}$

35 Ver http://www.titicacatour.com/tour-a-los-uros/ e http://titicacaperu.com/es/uros-clasico. html (tradução minha). 
Embora nenhum guia turístico que observei tenha mencionado a pesquisa genética, todos estabeleciam no seu discurso uma continuidade entre a população atual das ilhas e os Urus antigos.

Finalmente, outra área em que a pesquisa genética levanta perguntas importantes se refere às próprias conceptualizações dos Uros. No caso de uma eventual incorporação futura da genética dentro da vida social deles, qual será o efeito sobre a maneira em que eles constroem sua identidade e o significado de serem Uros?

Uma das características principais da vida nas ilhas flutuantes é a flexibilidade social, uma característica que se estende às estratégias identitárias dos Uros. Contudo, a maneira como as autoridades dos Uros, assim como seus simpatizantes em Puno, se envolveram com a pesquisa genética revela um conceito da genética como uma ferramenta para determinar uma identidade coletiva sem ambiguidades, para fixá-la de forma definitiva. Seria necessário explorar como esse ímpeto fixador interage com as estratégias identitárias mais flexíveis dos Uros, seja no âmbito político, seja no cotidiano das relações sociais internas.

Além disso, a identidade dos Uros - como é o caso das identidades étnicas nos Andes em geral - é constituída predominantemente por registros sociais e culturais. A genética, em contraste, oferece uma base biológica para a identidade. Os efeitos da incorporação de registros biológicos dentro de processos de construção de identidades coletivas e individuais entre os Uros é outro campo que precisa ser explorado em pesquisa futura.

\section{Consideração final}

Para mim, talvez o elemento mais surpreendente nesse debate seja que de todos os registros acionados para falar da identidade dos Uros, aquele que menos parece ser tomado em consideração é o registro dos próprios Uros: seu estilo de vida nas ilhas flutuantes e a sua ligação íntima com o lago e seus recursos. Portanto, para concluir gostaria de me permitir uma pequena liberdade retórica para sugerir uma inversão 
da pergunta central que se costuma fazer nesse tipo de debate - uma inversão que poderia levar a respostas significativamente diferentes, e também a um olhar distinto sobre a questão das identidades indígenas em geral. Dado o seu estilo de vida particular nas ilhas flutuantes e a sua sociabilidade muito idiossincrática resultando dessa vida - e que os diferenciam claramente de populações ribeirinhas Aymaras e Quéchuas -, o que podem os Uros ser a não ser Uros?

\section{Referências}

BOUYSSE-CASSAGNE, T. Le Lac Titicaca: histoire perdue d'une mer intérieure. Bulletin Institut francais études andines, 21(1): 89-159, 1992.

.\& HARRIS, O. Pacha: en torno al pensamiento Aymara. In: BOUYSSE-CASSAGNE, T. et al. (ed.). Tres reflexiones sobre el pensamiento andino. La Paz: Hisbol, 1987.

BRODWIN, P. Genetics, identity, and the anthropology of essentialism. Anthropological Quarterly, 75(2): 323-330, 2002.

CEPID. Plan Maestro Reserva Nacional Titicaca. Lima: Universidad Nacional Agraria, La Molina, 1979.

CERRÓN PALOMINO, R. El chipaya o la lengua de los hombres del agua. Lima: Pontífica Universidad Católica, 2006.

CONKLIN, B. A. Body paint, feathers, and VCRs: aesthetics and authenticity in Amazonian activism. American Ethnologist, 24(4): 711-737, 1997.

CÓRDOVA, J. H. et al. Poblamiento del continente americano y del Perú sugerido de un análisis filogeográfico de haplogrupos del mtDNA en etnias nativas. I: inferencias primarias. Archivos de Biologia Andina, 14(1): 23-39, 2008.

DE LA CADENA, M. Indigenous mestizos: the politics of race and culture in Cuzco, Peru, 1919-1991. Durham: Duke University Press, 2000.

. Are mestizos hybrids? The conceptual politics of Andean identities. Journal of Latin American Studies, 37: 259-284, 2005.

DELGADO SILVA, B. et al. Polimorfismos del ADN mitocondrial en los nativos de las islas "Islas los Uros" del Lago Titicaca-Perú. Revista Sciendo, 5(1-2): 21-29, 2002. 
GOODMAN, A. H.; HEATH, D. \& LINDEE, M. S. Genetic nature/culture: anthropology and science beyond the two-culture divide. Berkeley: University of California Press, 2003.

GREENBERG, J. H. Language in the Americas. Stanford: Stanford University Press, 1987.

GUEVARA-GIL, A. Espejismos desarrollistas y autonomia comunal: el impacto de los proyectos de desarrollo en el lago Titicaca (1930-2006). Lima: Pontificia Universidad Católica del Perú, 2007.

HANSON, A. The making of the Maori: cultural invention and its logic. American Anthropologist, 91(4): 890-902, 1989.

HARRIS, O. Ethnic identity and market relations: Indians and mestizos in the Andes. In: LARSON, B.; HARRIS, O. \& TANDETER, E. (Eds.). Ethnicity, markets, and migration in the Andes: at the crossroads of history and anthropology. Durham: Duke University Press, 1995.

HOBSBAWM, E. \& RANGER, T. (eds.). The invention of tradition. Cambridge: Cambridge University Press, 1983.

KENT, M. From reeds to tourism: the transformation of a territorial conflict in the Titicaca National Reserve. Current Issues in Tourism, 9(1): 86-103, 2006. The making of customary territories: social change at the intersection of state and indigenous territorial politics on Lake Titicaca, Peru. Journal of Latin American and Caribbean Anthropology, 14(2): 283-310, 2008.

. How to make the state listen: indigenous violence, state fears and everyday politics in Peru. Etnofoor, 21(2): 11-34, 2009.

KOENIG, B. A.; LEE, S. S.-J. \& RICHARDSON, S. S. Revisiting race in a genomic age. New Brunswick: Rutgers University Press, 2008.

MERRIWETHER, D. A. et al. MtDNA variation indicates Mongolia may have been the source for the founding population for the New World. Journal of Human Genetics, 59: 204-212, 1996.

ORLOVE, B. S. Mapping reeds and reading maps: the politics of representation in Lake Titicaca. American Ethnologist, 18(1): 3-38, 1991.

PALSSON, G. Genomic anthropology: coming in from the cold? Current Anthropology, 49(4): 545-568, 2008. 

RAMOS, A. R. Indigenism: ethnic politics in Brazil. Madison: University of
Wisconsin Press, 1998.

REDFORD, K. The ecologically noble savage. Orion Nature Quarterly, 9(3): 22-37, 1990

RIVET, P. \& CREQUIT-MONTFORT, G. de. La langue uru ou puquina. Journal de la Société des Américanistes, 17: 211-244, 1925.

RODRIGUEZ-DELFIN, L. A.; RUBIN-DE-CELIS, V. E. \& ZAGO, M. A. Genetic diversity in an Andean population from Peru and regional migration patterns of Amerindians in South America: data from Y chromosome and mitochondrial DNA. Human Heredity, 51: 97-106, 2001.

ROSALDO, R. Ideology, place, and people without culture. Cultural Anthropology, 3(1): 77-87, 1988.

SAHLINS, M. Goodbye to tristes tropes: ethnography in the context of modern world history. The Journal of Modern World History, 65(1): 1-25, 1993.

. Two or three things that I know about culture. Journal of the Royal Anthropological Institute, 5(3): 399-416, 1999.

SALAZAR, V.; CALLISAYA, P. \& ORTIZ, J. Entre el crepúsculo y la claridad, el amanecer de los primeros hombres en el mundo Andino, los Urus. La Paz: Taller de Historia Oral Andina, 2003.

SANDOVAL, J. et al. Variantes del ADNmt en isleños del Lago Titicaca: máxima frequencia del haplotipo B1 y evidencia de efecto fundador. Revista Peruana de Biologia, 11(2): 161-168, 2004.

SANTOS, R. V. Indigenous peoples, postcolonial contexts and genomic research in the late 20th century. Critique of Anthropology, 22(1): 81-104, 2002.

THOMAS, N. The inversion of tradition. American Ethnologist, 19(2): 213232, 1992.

TORERO, A. Acerca de la familia linguistica Uruquilla (Uru-Chipaya). Revista Andina, 1: 171-189, 1992.

WACHTEL, N. Hommes d'eau: le problème uru (XVI-XVII siècles). Annales E. S. C., 33(5-6): 1.127-1.159, 1978

. Le Retour des Ancêtres - les Indiens Urus de Bolivie, XXe-XVIe siècle.

essai d'histoire régressive. Paris: Gallimard, 1990. 
WADE, P. The guardians of power: biodiversity and multiculturality in Colombia. In: CHEATER, A. (ed.). The anthropology of power: empowerment and disempowerment in changing structures. London: Routledge, 1997.

Race, ethnicity and nation: perspectives from kinship and genetics. New York: Berghahn Books, 2007. 


\section{BIORREVELAÇÕES: TESTES DE ANCESTRALIDADE GENÉTICA EM PERSPECTIVA ANTROPOLÓGICA COMPARADA ${ }^{1}$}

Verlan Valle Gaspar Neto Ricardo Ventura Santos Michael Kent

\section{Introdução}

Se você não conhece sua herança, você não pode saber plenamente quem você é. Se você não sabe quem você é, outros farão essa definição por você. Se outros definem você, eles tendem a defini-lo em termos que os colocam numa posição de poder e você numa posição de subjugação. Se você não conhece sua história, você não pode traçar a trajetória que Deus planejou para a sua vida e a de sua família. (Depoimento de Kenneth Edward Copeland) $)^{2}$

1 Este texto é produto do projeto de pesquisa "Raça, genômica e mestiçagem na América Latina: Uma abordagem comparativa", coordenado por Peter Wade (University of Manchester) e, no Brasil, por Ricardo Ventura Santos (financiado pelo ESRC - Economic and Social Research Council, n. RES-062-23-1914, Inglaterra). Agradecemos a Emerson Sena, Luiz Fernando Dias Duarte, Peter Fry e Peter Wade pelos comentários acerca de uma versão prévia deste ensaio. O presente capítulo é uma versão expandida e revisada de artigo de autoria de Verlan Valle Gaspar Neto e Ricardo Ventura Santos, de título homônimo, publicado em Horizontes Antropológicos (v. 17: 197-226, 2011). Optamos, para fins deste capítulo, não reproduzir imagens divulgadas no texto original, as quais poderão ser acessadas, pelos leitores interessados, a partir da página eletrônica do periódico na base Scielo.

2 Todos os testemunhos referentes ao African Ancestry estão disponíveis em http://www. africanancestry.com. Foram cessados em 23 abr. 2010 e traduzidos do inglês para o português pelos autores deste capítulo. 
O dia em que Kenneth Edward Copeland, um pastor de igreja norte-americano, recebeu os resultados de seu teste de ancestralidade genética asseverando sua estreita relação biológica com a Nigéria, foi exatamente o mesmo do nascimento de sua filha. Para ele, tratava-se não de uma mera coincidência, mas de um sinal divino que punha ele e sua família em uma espécie de conexão também espiritual com a África. A descoberta de sua ascendência Iorubá e a vinda ao mundo de sua filha significavam, conforme se depreende de seu depoimento na página eletrônica da empresa especializada na realização de testes de ancestralidade genética voltados para afro-americanos, African Ancestry, que a diáspora do povo africano estava garantida, inclusive como um plano de Deus. Essa (bio)revelação operou uma transformação tão profunda em sua vida que a criança recém-nascida foi imediatamente nomeada Abeni, o que, segundo Copeland, significa "nós oramos pela chegada dela" em iorubá. As genealogias tão bem explicitadas na Bíblia, assim como o elo biológico e espiritual com o continente do qual vieram seus antepassados, estavam reafirmadas através da "consagração" de sua filha.

Relatos com teor parelho a este não são incomuns de serem encontrados nas páginas eletrônicas de empresas dedicadas à realização de testes de ancestralidade genética (ou genômica), principalmente nos Estados Unidos e na Europa. ${ }^{3}$ Claro, a exacerbação da dimensão espiritual aqui relatada se deve, em grande parte, ao fato de o autor do testemunho ser um pastor de igreja e, por isso mesmo (mas não só por isso), vivenciar a experiência de ter sua ascendência étnica biologicamente retratada como algo também espiritual.

3 Como boa parte dos relatos reproduzidos neste trabalho advém das páginas eletrônicas das empresas aqui destacadas, cumpre-nos assinalar que, possivelmente, os critérios empregados para a sua divulgação estão relacionados às formas como as empresas gostariam de ser vistas aos olhos dos clientes, ou seja, como peças de marketing. Em nosso entender, contudo, isso não diminui sua importância para fins de análises antropológicas, já que, para além da dimensão econômica, eles também podem ser entendidos como uma amostra de como as empresas gostariam que seus produtos, os testes de ancestralidade, fossem apreendidos no plano sociocultural. Vale adicionar ainda que diversos depoimentos, aparentemente, correspondem a relatos verídicos, já que há nomes e imagens associadas a eles, inclusive de personalidades. 

O relato com o qual abrimos este ensaio é apenas uma amostra
daquilo que vários pesquisadores têm identificado em suas aborda-
gens acerca das implicações ques os gens acerca das implicações que os conhecimentos e as tecnologias geradas no âmbito da Biologia e da Medicina, incluindo-se os testes de ancestralidade genética, podem vir a ter sobre as vidas daqueles que se aventuram a se submeter a eles. De fato, o que alguns destes estudos têm demonstrado é que, em um cômputo geral, cada vez mais, à medida que a área biotecnológica se desenvolve e se alastra por todos os domínios nos quais a vida humana (e não humana) é posta em perspectiva, o movimento de "biologização" do mundo se espraia (Bolnick et al., 2007; Santos et al., 2010). Este tipo de discussão, que já se encontrava presente nas obras de um Michel Foucault (1988) e de um Paul Rabinow (2002), com as noções de biopoder e biossociabilidade, respectivamente, vem ganhando contornos mais etnográficos nos últimos tempos (Pálsson 2007; Gibbon \& Novas 2008; Santos et al., 2009; Koenig et al., 2008; Comaroff \& Comaroff 2009).

Dentro do escopo de possibilidades investigativas nas quais a interface entre a natureza e a cultura parecem se encontrar de forma nítida, com a consequente proliferação daquilo que Bruno Latour (2005) identificou como quase-sujeitos/quase-objetos, os testes de ancestralidade genômica vêm desempenhando um papel de destaque. O panorama com o qual nos defrontamos hoje, cotidianamente, é o de que a Genética é apresentada como possuindo, de modo potencial e/ou efetivo, a resposta para muitas das inquirições, zadas em testes de ancestralidaro colocados. Empresas especialicomo um dos pontos críticos deste cenário podem ser entendidas dos casos, estas empresas apresentam cenário. Na quase totalidade ções que permitirão a um indiví́dam seus produtos como revelacomunidade descobrir o que, "de fato" e, por que não, "de direstia uma eles são (ver Comaroff \& Comaroff 2007; Santos et al., 2010). 
Segundo Bolnick et al. (2007), a despeito de serem chamados de genética recreativa, ou de serem uma nova roupagem para o antigo hobby de se pesquisar árvores genealógicas a partir de critérios como o sobrenome familiar, os testes de ancestralidade genômica possuem poderosas implicações sociais. Quando alguém se submete a algum destes testes, no mais das vezes o faz orientado por questões que vão além da mera curiosidade, mesclando aspectos de ordem pessoal, política e/ou ideológica, além da dimensão de "mística do DNA" referida por Nelkin \& Lindee (1995). É que os clientes de testes de ancestralidade demonstram uma predisposição para alinhar a interpretação dos resultados do teste com suas trajetórias e desejos pessoais (Nelson, 2008). Neste sentido, não seria demais acrescentar que a interpretação dos resultados de um teste de ancestralidade genética pode interferir em dimensões que vão do senso de identidade (seja em que amplitude for) ao sentimento familiar, da aceitação ou negação do conceito de "raça" ao racismo, de perspectivas espirituais a ideários políticos (Bolnick et al., 2007).

Além de "criar" pessoas e personalidades ou núcleos familiares ancorados em uma pretensa ancestralidade comum (Comaroff \& Comaroff, 2009; Nelson, 2008; Pálsson, 2007; Santos et al., 2010), os testes de ancestralidade podem gerar atrabiliárias discussões quando aplicados a contingentes populacionais mais amplos. Como mostra Pálsson (2007), por meio de relatos etnográficos e pesquisas junto à imprensa internacional, iniciativas empresariais de armazenamento, registro e escrutínio de materiais biológicos humanos, inclusive para fins de saúde pública e montagem de genealogias associados a temas como parentesco, nacionalidade e cidadania, sempre observados sob um viés genético, tornaram-se alvo de amplos debates públicos em contextos nacionais como Islândia, Inglaterra, Tonga, Canadá, Taiwan, Estônia e Suécia. Portanto, para além da esfera microscópica das relações interpessoais e de parentesco, o alcance do impacto destes tipos de testes pode ser muito maior na medida em que as 
análises de genealogia genética são vistas enquanto ferramentas capazes, concreta e simbolicamente, de corroborar ou contrapor medidas institucionais voltadas para o beneficiamento político, econômico e social de grupos sociais, quer sejam eles minoritários ou não (Bolnick et al., 2007).

Um aspecto dos testes de ancestralidade genética que tem atraído particular atenção são as suas implicações sobre as ideias de raça e etnicidade. Com efeito, estes testes estão parcialmente baseados na crença difundida, tanto entre leigos quanto entre um significativo número de geneticistas, de que existem grupos ou populações geneticamente distintos passíveis de serem identificados de modo quantitativo e até mesmo qualitativo. Enquanto no princípio do século XXI parecia haver um consenso, dentro do campo global da genética, de que não existem bases biológicas para a ideia de raça, nos anos subsequentes ocorreu uma notável mudança em direção à racialização das pesquisas, particularmente nos Estados Unidos, onde o uso das categorias raciais se tornou uma prática padrão (Fullwiley, 2007; Lee, 2008). ${ }^{4}$ Uma interessante exceção a esta tendência geral é o caso do Brasil, contexto no qual os geneticistas continuam, enfaticamente, a negar a existência de raças biológicas (Santos e Maio, 2004). Como mostrado mais adiante, tais contextos institucionais diferenciados entre países tem efeitos significativos sobre os tipos de testes de ancestralidade oferecidos.

Vale ressaltar, ainda, que a ideia de "raça" permanece lucrativa porque serve de atrativo para consumidores que se sentem pertencentes ou próximos a um dado perfil étnico-racial (Bolnick et al., 2007). Empresas que defendem em suas respectivas páginas eletrônicas a inexistência de "raças" enquanto entidades biológicas são as mesmas a oferecer testes de ancestralidade genética para grupos etnicamente delineados, no mais das vezes de modo sub-reptício.

4 Por exemplo, na área de saúde, vultosas somas são aplicadas no desenvolvimento de serviços, testes e medicamentos voltados para o atendimento de grupos étnicos/ raciais supostamente vulneráveis a tipos específicos de achaques provenientes de mutações genéticas deletérias localizadas com frequência particular entre eles. 
Nas páginas que se seguem nós exploramos, enquanto um estudo de caso e a partir de uma perspectiva antropológica comparativa, os perfis de três empresas, situadas em diferentes países, que comercializam testes de ancestralidade genética: African Ancestry, nos EUA; Oxford Ancestors, na Inglaterra; Laboratório GENE, no Brasil. O intuito é tomar as duas primeiras como contraponto comparativo à última, a fim de avaliar o que as aproxima e distancia no tocante ao trato concedido ao potencial revelador de seus respectivos testes e, também, com que teor questões como pertença étnica/ racial perpassam o merchandising de seus produtos e a sua postura pública. Em um plano mais amplo, será argumentado que contextos sociopolíticos específicos influenciam as formas como os testes de ancestralidade genética são apresentados e justificados para seus respectivos públicos de consumidores. No caso específico da empresa brasileira, situá-la no panorama histórico-antropológico mais amplo sobre "raça" e relações raciais, assim como nos debates correntes, ajuda-nos a compreender como os testes de ancestralidade são justificados e. apresentados à sociedade.

Além disso, este capítulo explorará os modos pelos quais as escolhas metodológicas empregadas em testes de ancestralidade genética, em certa medida, moldam as experiências específicas dos consumidores que se submetem aos testes de ancestralidade, e, em particular, as comunidades com as quais tais testes os conectam. Populações e identidades significativamente diferentes podem emergir a partir de pesquisas genéticas com o mesmo conjunto de amostras, a depender das tecnologias empregadas e das partes do DNA que são focadas, bem como do tipo e número de marcadores utilizados. ${ }^{5}$

5 Há testes envolvendo DNA mitocondrial, material genético do cromossomo Y e DNA autossômico. O DNA mitocondrial é transmitido apenas por mulheres para seus filhos e filhas, e não sofre recombinação, sendo usado para traçar a ascendência materna. Já o material genético do cromossomo Y, que passa de pai para filho, também não sofre Em ambos os casos maior porção, e é empregado para traçar a ascendência paterna. bretudo em curtos intervaçoes podem ocorrer mediante mutações, mas são raras, so- 
Assim, a diversidade genética não se mostra como uma realidade biológica independente, mas, antes, como construída através de práticas científicas específicas (Barnes e Dupré, 2008; M'Ccharek, 2005).

Passemos, pois, aos dados propriamente ditos. Em um primeiro momento apontaremos as informações concernentes às duas empresas internacionais para, por conseguinte, expor aquelas referentes ao caso brasileiro e que ilustram a discussão aqui levantada. ${ }^{6}$

\section{De Adão e Eva a clãs genômicos ancestrais}

Quando um visitante acessa a página eletrônica da empresa norte-americana especializada em testes de ancestralidade genética voltados para afro-americanos, African Ancestry, a primeira coisa com a qual ele se depara é um conjunto de slides com a seguinte mensagem: ${ }^{7}$

Aprenda porque African Ancestry é a resposta. Você sabe de aonde vem? Não a cidade aonde você nasceu, mas o lugar aonde seus ancestrais se originaram há mais de 500 anos. Finalmente, com African Ancestry você pode descobrir as raízes da sua arvore familiar, traçar seu DNA, encontrar suas raízes. Você sabe? African

humanos, encontra-se distribuído em 22 pares de cromossomos - sofre altos níveis de recombinação, e cada um dos pais contribui com metade do material herdado. Sendo assim, as características particulares de cada forma de DNA revelam diferentes aspectos da ancestralidade genética de um indivíduo ou grupo, e referem os sujeitos de análise genética à comunidades diferenciadamente moldadas. Enquanto o DNA mitocondrial e o cromossomo Y são técnicas que permitem o estabelecimento de conexões diretas com o passado distante e origens geográficas específicas, o DNA autossômico é particularmente adequado para revelar a miscigenação em um nível individual no interior de uma população miscigenada contemporânea.

6 Os dados foram obtidos a partir de uma ampla coleta realizada em âmbito virtual, conduzida no período de 23 de abril a 2 de julho de 2010 . Foram consideradas praticamente todas as informações disponibilizadas nas páginas eletrônicas das referidas empresas, as quais, entre outras coisas, contam com links para matérias publicadas na imprensa sobre os seus trabalhos (principalmente o Laboratório GENE) e também espaços nos quais seus usuários dão seus testemunhos sobre as percepções e as experiências a partir dos resultados dos testes (apenas African Ancestry e Oxford Ancestors).

7 Sugerimos consultar Bolnick (2008) e Bolnick et al. (2007) para uma discussão sobre os pressupostos e os problemas metodológicos envolvidos nos testes de ancestralidade genética comercializados pelas principais empresas norte-americanas e europeias. 
Ancestry é a única empresa que pode traçar sua ancestralidade de volta a um país africano de origem. (Disponível em: http:www. africanancestry.com)

Com um banco de dados derivado de milhares de amostras de DNA coletadas junto a nativos africanos, correspondentes a 30 países e a mais de 200 grupos étnicos, a empresa, liderada pela economista Gina Paige (presidente) e pelo geneticista Rick Kittles (diretor científico), atesta ser a única do gênero capaz de traçar a ancestralidade genética de um indivíduo de modo a descobrir de que país e grupo étnico, especificamente, ele descende. No marketing da companhia, a ênfase na África e na negritude é predominante. De acordo com Kittles, "African Ancestry é a única companhia (de genealogia genética) que se foca nos afro-descendentes; ela é gerenciada por gente negra e irá permanecer deste modo" (in Nelson 2008: 256). O intuito é, conforme aparece em vários momentos na página eletrônica, proporcionar aos clientes uma vasta gama de experiências que lhes permitirão descobrir quem eles realmente são, incitando-lhes a uma reorientação das perspectivas culturais, psicológicas, físicas e emocionais que eles têm sobre si mesmos e sobre o continente de onde vieram seus antepassados.

Mas ao querer comungar destas benesses, é importante que o cliente note que um teste de ancestralidade genética é, na verdade, um projeto de família, pois, na medida em que os resultados de uma pessoa podem ser estendidos aos de outrem que partilhem um mesmo grupo ancestral, uma rede de conexões é estabelecida entre os que se submetem aos testes e entre estes e seus respectivos países e grupos originários. É o que se vê, por exemplo, na identificação daqueles clientes que optaram por se manter no anonimato, chamados de "membro da família African Ancestry". Esta viagem de volta ao lar primordial através da (bio) revelação dos segredos escondidos no DNA mitocondrial e no cromossomo Y serviria também a um propósito histórico, cultural e identitário - ajudar a preencher as lacunas 
deixadas pelo sistema escravocrata norte-americano. De acordo com Kittles, os testes de ancestralidade permitem a seus clientes superar as limitações de identificar a si mesmos somente através das categorias genéricas "negro" e "afro-americano", ao mesmo tempo restabelecer uma conexão com partes e grupos étnicos específicos do continente africano, assim como o fazem os demais cidadãos norte-americanos com relação à Europa (Winston \& Kittles 2005). Conforme sugerem as palavras de Kenneth Copeland citadas anteriormente, traçar a ancestralidade através da análise genética não é apenas uma questão de curiosidade pessoal. É por extensão um ato político: definir quem você é possui um efeito de empoderamento dentro de uma arena social conceitualizada em termos competitivos. $\mathrm{O}$ estabelecimento de tais conexões diretas com o continente africano é facilitado pelas concepções de raça e descendência presentes nos Estados Unidos: como o DNA mitocondrial e o cromossomo Y revelam apenas um dentre os muito possíveis ancestrais ${ }^{8}$ de um indivíduo, esta técnica genética está bem alinhada com a "regra de uma gota", princípio central de organização da identidade racial naquele país (Lee et al., 2001: 50).

A dádiva, naturalmente, envolve um conjunto de objetos que, sem dúvida, poderiam vir a formar um relicário. Eles simbolizam material e externamente aquilo que se encontra inscrito nos pontos mais recônditos dos corpos. O pacote de resultados enviado por correspondência pela African Ancestry engloba uma carta na qual consta a revelação da ancestralidade; a sequência de DNA analisada de forma impressa; um certificado (ou diploma) de ancestralidade; um mapa da África, colorido; um guia de referência sobre os países africanos; e o acesso à comunidade on-line da empresa.

Ao menos nos relatos aos quais se tem acesso, o apelo parece funcionar. Testemunhos de anônimos e celebridades demonstram que o

8 Voltando 400 anos - aproximadamente 16 gerações -, o número máximo de ancestrais
diretos poderia ser 65.536 . 
mundo daqueles para os quais os segredos genéticos foram revelados, passa a se caracterizar por um apanhado de transformações repletas de logro e alegria. Esta promessa de redenção parece se materializar na experiência de James Bullock: "Sinto-me mais pleno. Agora eu possuo uma profunda conexão pessoal com meus ancestrais, suas vidas e seu mundo". Para um cliente anônimo, o estabelecimento de tal conexão com uma parte específica do continente africano engendrou um senso de volta ao lar: "Agora eu tenho um vínculo com um lugar que eu posso chamar de lar". O possível efeito de empoderamento - já sugerido pelo pastor Copeland - torna-se evidente no testemunho da atriz Kimberly Elise, que passou a se sentir mais fortalecida porque descobriu ser descendente dos Songhai, uma tribo africana de artesãos e guerreiros reais:

Eu venho do povo Songhai e através da minha pesquisa eu aprendi que meus ancestrais são conhecidos por serem grandes artesãos, por sua realeza e por serem guerreiros de grande força e habilidade. Saber que esses traços são a composição nuclear do meu DNA coloca todas as peças de quem eu sou instintivamente no lugar, e me dá fortaleza para continuar vivendo como eu tenho vivido.

Além disso, o testemunho de Kimberly também mostra os modos pelos quais os consumidores associam os resultados de seus testes de ancestralidade com suas trajetórias pessoais e aspirações pessoais, ou seja, ela se sente feliz por saber que, sendo uma songhai, poderá transmitir (geneticamente, provavelmente) aos filhos os dons artísticos e a realeza que ela mesma herdou de sua tribo. Por seu turno, uma professora optou por um teste de ancestralidade após retornar de uma viagem à Africa: "Até então, eu tinha reivindicado o continente inteiro porque era claro para mim que eu era africana. Quando voltei para os Estados Unidos, decidi que precisava saber de aonde eu vinha". Ela coloca que sua vida foi modificada radicalmente. Tanto que ela mandou fazer cópias de seu diploma genético para distribuir entre os parentes e amigos e passou a andar com cópias dos mesmos em sua 
bolsa todos os dias. É que, para ela, a verdade inscrita em seu DNA, revelada pelos testes de ancestralidade genética, é inquestionável: "Eu os compartilho com meus alunos que costumam se chamar pela palavra 'n'. Digo-lhes: 'Vejam, não tem nenhum 'n' no meu DNA... e posso garantir que também não tem no de vocês!!".

O que o testemunho acima sugere é que os testes de ancestralidade genética não somente operam uma redefinição da identidade em termos positivos, mas, ainda, a troca de rótulos de identidade genéricos conectados ao continente americano - tais como o pejorativo "nigger" aqui referido - por identidades étnicas específicas localizadas no continente africano. Esta transição se torna particularmente evidente no seguinte testemunho, de Cedrick White:

Minha ancestralidade maternal combinou 98,9\% com os Yorubá, da Nigéria... e minha ancestralidade paterna combinou $100 \%$ com os Akan, de Gana... Eu ainda tenho que celebrar, é confirmação em cima de confirmação!!!!!!!!!!!!!!!! Oooooooobbbbaaaaaaaa!!!!! Da infầncia à maturidade, meu destino tinha apenas sussurrado verdade sobre verdade, e, de fato, eu tenho a prova científica para atestá-la!!!! (Americano Nigeriano-Ganês, já não apenas um Afro-americano genérico!!!)

Assim, as transformações identitárias operadas pelos testes de ancestralidade genética da African Ancestry não só se inserem em um duplo movimento de desterritorialização e reterritorialização (Deleuze \& Guattari, 1996), indo do continente americano para o continente africano, mas também operam uma transição do genérico para o específico.

Ressalte-se ainda que uma característica central da diáspora africana é que, enquanto resultado do sistema escravocrata, as conexões com os locais de origem foram cortadas e identidades étnicas específicas foram substituídas por rótulos mais genéricos, tais como afro-americanos (Gomez, 1998). As experiências proporcionadas pelos testes genéticos da African Ancestry parecem inverter este 
processo. A ênfase concedida à existência de grupos étnico-raciais identificáveis geneticamente permite aos clientes romper com a categoria de afro-americano. O projeto familiar da empresa não é apenas o de uma família, mas antes, o de um conglomerado de mais de 200 pequenas famílias tribais que devem ser assumidas enquanto tais de modo a permitir que seus filhos pródigos de além-mar retornem, espiritual e, muitas vezes, fisicamente, a elas. Uma parte substancial do incentivo a isto está no "Muro do retorno", parte do site na qual aparecem inscritos os nomes de clientes famosos como Oprah Winfrey e Morgan Freeman, cujas ancestralidades genéticas remontam, respectivamente, à Libéria e à Nigéria.

Este deslumbramento diante das revelações obtidas mediante a consulta a um teste de ancestralidade genética também é encontrado na outra empresa aqui considerada, Oxford Ancestors, bem como em algumas outras já analisadas em estudos antropológicos e da área dos estudos sociais da ciência. ${ }^{9}$

A Oxford Ancestors, situada na Inglaterra, foi uma das primeiras empresas a oferecer testes de ancestralidade genética no mundo. Segundo relato disponível em sua página eletrônica, o empreendimento surgiu após a crescente visibilidade pública e acadêmica dos trabalhos de seu fundador e responsável, na Universidade de Oxford, o geneticista Bryan Sykes, o qual se tornou uma referência mundial em análises de DNA mitocondrial, cromossomo Y e, principalmente, na extração de material genético proveniente de fósseis. Quando, em 2001, ele lançou seu mais famoso livro, resultado de seus estudos genéticos, The Seven Daughters of Eve, a demanda por testes de ancestralidade genética referentes a grupos ancestrais europeus cresceu exponencialmente..$^{10}$

9 Ver, entre outros, Pálsson (2007), Santos et al. (2010) e estudos de caso em Koenig et al. (2008).

10 Como mostrado na página eletrônica da Oxford Ancestors, as credenciais acadêmicas de Sykes são um importante elemento no marketing da empresa. 
Embora menos contundente do que a African Ancestry, inclusive iconograficamente, a Oxford Ancestors apresenta igualmente como "missão" permitir que seus usuários possam (re)descobrir suas origens a partir de seu próprio material genético. Versando para potenciais clientes, Bryan Sykes, na mensagem inicial da página eletrônica, convida as pessoas a darem um voto de confiança às credenciais do grupo liderado por ele, haja vista que os produtos oferecidos pela empresa têm sua origem em pesquisas desenvolvidas em um âmbito acadêmico (universitário) de grande prestígio internacional, qual seja, o da Universidade de Oxford.

Segundo a empresa, na parte dedicada às perguntas e respostas mais frequentes, os testes de ancestralidade genética oferecidos em sua cartela de produtos não podem identificar o fundo étnico-racial de uma pessoa porque não há qualquer base genética que corrobore a existência de "raças". Esta é uma colocação interessante porque a "raça", ou o caráter étnico, explicitamente negados, parecem ser fazer presentes, ainda que implicitamente, sob a alcunha de clãs ancestrais geneticamente diferenciados e identificáveis. Sob este prisma, a Oxford Ancestors atesta a existência de 36 clãs maternos e 18 clãs paternos ancestrais ao redor do mundo. Deste contingente, seus testes seriam capazes de identificar para o continente europeu um total de 12 clãs ancestrais e nativos, sete matrilineares e cinco patrilineares.

Estes clãs, por sua vez, estão relacionados a um "casal" primordial alegoricamente identificado como "Eva Mitocondrial" e "Adão do Cromossomo $Y^{\prime}$, , respectivamente. ${ }^{11}$ Mas não é em direção a eles que os clientes da Oxford Ancestors trilharão seu caminho de volta "ao lar". A especialidade da empresa é oferecer aos seus clientes a oportunidade de chegar a pontos espaçotemporais menos distantes, porque, tal qual no

11 A palavra casal aparece aqui assinalada entre aspas porque, na verdade, conforme as informações disponibilizadas na página eletrônica da referida empresa, há um considerável hiato temporal entre as suas partes constituintes. A Eva Mitocondrial teria vivido na África entre 150 e 200 mil anos, ao passo que o Adão do Cromossomo Y teria habitado o mesmo 
caso da African Ancestry, o que temos aqui não é apenas "um lar", mas antes, um conjunto de "lares específicos" que permite possibilidades de identificação particularizadas no seio de uma categoria maior-europeu.

A página eletrônica oferece informações e identificações apenas para os clãs de linha materna, denominados "As Sete Filhas de Eva" ${ }^{12}$ Apresentados em uma perspectiva temporal que parte do mais antigo para o mais recente, para cada um deles são encontradas informações que mesclam localização geográfica presente e pretérita (origem e dispersão) e índices percentuais de representatividade genética dentro da população europeia atual. O clã de Xênia, por exemplo, o segundo mais antigo, remete há 25.000 anos e computa $7 \%$ dos nativos europeus em três ramos assim distribuídos: Europa Oriental, Europa Ocidental e Centro do continente europeu. Desse modo, um cliente com descendência materna europeia da Oxford Ancestors pode descobrir ser proveniente de Úrsula ("pequena ursa", em latim), Velda (governante, em escandinavo) ou Tara (montanha pedregosa, em gaélico), entre outras. As (bio)revelações proporcionadas pela Oxford Ancestors também causam impactos e permitem a criação de redes de biossociabilidade (Rabinow 2002) acompanhadas de movimentos de desterritorialização e reterritorialização (Deleuze \& Guattari, 1996) reais e virtuais pautadas no sentimento de pertença a uma determinada tribo ancestral. ${ }^{13}$ Vejamos alguns testemunhos ilustrativos, cujos autores só estão originalmente identificados por iniciais e país de origem:

Obrigado por me enviarem os resultados do meu teste de ancestralidade das tribos britânicas. Eu devo dizer que agora eu estou me sentindo realmente "nórdico" e tenho comido mais peixe e ansiado por mares abertos. Este é realmente um fascinante projeto,

12 A empresa não disponibiliza, ao menos publicamente, informações e nem identificações específicas para os supostos cinco clãs masculinos provenientes do Adão do Cromossomo Y.

13 A empresa oferece aos seus clientes a oportunidade de, uma vez cientes de sua ascendência, partilhar informações e experiências entre si através de uma página de relacionamentos acessível apenas àqueles cadastrados. 
e muitos dos meus amigos e parentes estão pretendendo descobrir se eles também são Vikings. - $G G$, Inglaterra ${ }^{14}$

De modo similar àquele dos clientes da African Ancestry, este testemunho mostra tanto um senso de pertença a uma comunidade enraizada em um passado distante quanto o alinhamento de histórias pessoais às características projetadas sobre esta comunidade. Este sentimento de conexão à uma comunidade mais limitada, baseado no estabelecimento de liames a ancestrais específicos, torna-se evidente, também, nos seguintes exemplos, testemunhos provenientes de clientes que habitam a Oceania:

No último capítulo do livro, As Sete Filhas de Eva, você fala do sentimento de um senso de conexão entre os membros do mesmo clã. Eu compreendo perfeitamente e agora eu aprecio me comunicar com essas pessoas através da sua página eletrônica. - $B S$, Sydney, Austrália

Eu sinto que eu pertenço a algo maior do que eu mesmo e que não estou meramente à toa aqui, e que meus ancestrais venceram os problemas, as doenças e os perigos de vida para eu poder existir. Obrigado. - TP, New Zeland

Na próxima seção nós veremos como, para o caso brasileiro, ainda que os testes sejam concebidos, mesmo indiretamente, como revelações, o foco não está na busca por grupos ancestrais específicos, geneticamente distinguíveis e localizados, ou mais especificamente, tipos puros, mas antes, na mistura.

\section{Inclassificáveis: o brasileiro e a miscigenação}

A imagem pública do Laboratório GENE - Núcleo de Genética Médica, é estreitamente vinculada à figura de seu fundador e presidente, o médico geneticista Sérgio Danilo Pena, também professor titular de 14 Todos os testemunhos relacionados à Oxford Ancestors estão disponíveis em http://www.
oxfordancestors.com, e foram acessados em 02 mai. 2010 . 
bioquímica da Universidade Federal de Minas Gerais - UFMG. Entre outros procedimentos, o laboratório realiza testes diagnósticos de doenças de fundo genético, consultas de genética clínica, exames laboratoriais de citogenética e testes de paternidade. Oferece também testes de ancestralidade, incluindo ancestralidade materna (DNA mitocondrial), paterna (cromossomo Y) e autossômica (intitulado, pela empresa, como teste de ancestralidade genômica). É a única companhia no Brasil que oferece essa última modalidade de teste para o público geral.

De modo diferente ao que ocorre com as duas empresas descritas anteriormente, voltadas exclusivamente para os testes de ancestralidade, a página eletrônica do GENE, de um modo explícito, trabalha apenas com um pequeno marketing voltado para os testes dessa natureza. Há uma ênfase na dimensão qualitativa e pioneira de sua atuação como uma empresa dotada de produtos cientificamente certificados e confiáveis para fins de análises no campo da genética clínica, análises laboratoriais e testes de paternidade.

Essa quase ausência de referências diretas aos testes de ancestralidade genética na página do Laboratório GENE, com exceção das informações técnicas, não significa que haja pouca ênfase no tema. Nas porções denominadas TV GENE e GENE na Imprensa, o visitante se depara com um conjunto de links associados a matérias jornalísticas dedicadas à cobertura das pesquisas e serviços realizados pelo laboratório. Nelas, há entrevistas e colunas assinadas por Sérgio Pena (sobretudo em Ciência Hoje Online, da Sociedade Brasileira Para o Progresso da Ciência - SBPC), nas quais o geneticista expõe seus pontos de vista sobre variados assuntos relacionados não só à Biologia, mas também, à Antropologia, à História e à Filosofia. ${ }^{15}$

15 As matérias audiovisuais chegam a quase 50 , com 15 delas relacionadas ao tema genealogia por DNA. Já as matérias em meio impresso e eletrônico ultrapassam a marca de 300 publicações, entre notas, entrevistas, reportagens completas ou mesmo diminutas menções ao nome de Pena. Deste contingente, a grande maioria se refere aos testes de ancestralidade genética ou ao tema da composição étnica e racial do Brasil. O período histórico coberto é 2000-2010. 
É importante considerar aqui que Pena é responsável por influentes estudos relacionados à ancestralidade da população brasileira (Alves-Silva et al., 2000; Carvalho-Silva et al., 2001; Parra et al., 2003; Bastos-Rodrigues et al., 2006; Pena et al., 2009, 2011). Dentre eles, destaca-se Retrato molecular do Brasil (2000), cujos resultados e teor propositivo ganharam notoriedade pública justamente no momento em que o Brasil discutia seus últimos 500 anos de história. Neste trabalho, Pena e colaboradores articulam seus achados com as interpretações de alguns autores clássicos da antropologia, sociologia e história no Brasil, como Darcy Ribeiro, Gilberto Freyre e Sérgio Buarque de Holanda, de modo a colocar a pesquisa genética como também potencialmente geradora de uma "interpretação do Brasil" (Santos \& Maio, 2005).

Na última década, Sérgio Pena tornou-se um geneticista de grande visibilidade pública no Brasil, com marcante envolvimento nos debates sobre "raça" e relações raciais. Em artigo publicado no jornal Folha de São Paulo em 2 de agosto de 2006 (Caderno Opinião), escreveu: "Certamente, a humanidade do futuro não acreditará em raças mais do que acreditamos hoje em bruxaria". Para ele, só há uma possibilidade classificatória, em termos biológicos, para a humanidade: a individualidade, já que a espécie humana seria composta por mais de seis bilhões de indivíduos geneticamente diferenciados (Pena, 2008). Sob tal perspectiva, a população brasileira ganha lugar de destaque porque seu perfil genético é visto como um dos mais misturados do mundo, com contribuições de origem europeia, africana e ameríndia pouco vistas em escala semelhante em outras partes do mundo.

Segundo consta na página eletrônica do GENE, os exames oferecidos apresentam alguns diferenciais com relação àqueles disponibilizados por algumas empresas no exterior: são oferecidos testes de ancestralidade genômica autossômica (para a identificação do grau de mistura gênica), além dos de patrilinhagem e matrilinha- 
gem, e o mais importante, eles partem de metodologias científicas desenvolvidas no país: "Assim, o Laboratório GENE usa métodos desenvolvidos no Brasil, por brasileiros, maximizando a eficiência na análise da ancestralidade genética dos brasileiros" (Disponível em: http://www.laboratoriogene.com.br. Acesso em 10 jun. 2010). ${ }^{16}$

E o que significa a disponibilidade de uma bateria de testes voltados para o perfil genético dos brasileiros? Parece-nos que, diferente daquilo que encontramos nas propostas da Oxford Ancestors e da African Ancestry, o foco do Laboratório GENE está mais na mistura genética. E por que isso? Porque a realização de um teste de ancestralidade genética deste laboratório envolve entrar em contato com uma revelação que questiona a crença na ideia de pureza racial baseada tanto em atributos fenotípicos quanto em genealogias, tal qual demonstrado nas pesquisas de média e larga escala junto a indivíduos de diferentes perfis cromáticos e oriundos de diferentes partes do país (Parra et al., 2003).

Há ainda outro ponto a ser destacado. Mesmo que os testes de ancestralidade paterna, materna e genômica possam ser adquiridos separadamente, as instruções presentes na página eletrônica da empresa sugerem aos interessados em descobrir suas origens genéticas que se submetam aos três testes conjuntamente, de modo a obter informações complementares. É que as análises do DNA mitocondrial e do cromossomo Y revelam apenas o ancestral máximo, em cada linhagem, do indivíduo, para um dado grupo continental: europeu, africano ou ameríndio. Elas não revelam o mais importante a ser descoberto, que, segundo se lê, é o índice quantitativo de mistura gênica. Este índice só pode ser obtido mediante a submissão ao teste

16 Há na página do GENE uma crítica aos procedimentos de certas empresas estrangeiras que comercializam testes de ancestralidade, em particular aquelas que prometem predizer a ancestralidade local de um indivíduo dentro do continente africano: "Obviamente então quem alegar que pode apresentar este elevado nível de (pseudo-) precisão estará fazendo inferências sem base científica rigorosa, com intuitos comerciais e enganando o consumidor" (Disponível em: http://www.laboratoriogene.com.br, acesso em 10 de junho de 2010). 
de ancestralidade genômica, porque este envolve material genético recombinante. Logo, os testes de ancestralidade genômica, que não são oferecidos em nenhum dos dois casos anteriormente aqui trabalhados, demonstram o quanto somos misturados aqui no Brasil. Esta mistura, aliás, permitir-nos-ia ser identificados por um epíteto particular, conforme se depreende da entrevista concedida por Pena à jornalista Ana Lúcia Azevedo no jornal $O$ Globo em 11 de agosto de 2002: "O Brasil teve um processo de mistura genética inusitado na História, gerando o brasileiro atual, que decidimos chamar, irreverentemente, de Homo brasilis". ${ }^{17}$ Deste modo, através das prioridades metodológicas estabelecidas pelo Laboratório GENE, a construção que emerge com particular força dos testes de ancestralidade genética do laboratório é o brasileiro, um indivíduo misturado, síntese de diferentes origens, um contraste com relação às origens regionais e continentais que aparecem como o resultado dos testes oferecidos pela African Ancestry e pela Oxford Ancestors.

Essa ênfase no caráter miscigenado da população brasileira se encontra claramente exposta no modelo de certificado que sua empresa disponibiliza para aqueles que compram seus testes de ancestralidade. Além de ter os haplogrupos referentes à sua ancestralidade máterna e paterna identificados, inclusive geograficamente, os clientes do Laboratório GENE ainda podem visualizar seu "posicionamento genômico" no interior de um triângulo cujos vértices simbolizam os três grandes grupos continentais responsáveis pela conformação genética brasileira - ameríndios, africanos e europeus, o que, de certa forma, nos remete à clássica discussão de DaMatta (1984) sobre a realidade social brasileira.

Atentas às repercussões dos trabalhos de Pena, e interessadas em levar para o grande público suas descobertas feitas no âmbito

17 Este epíteto é também o título de uma coletânea de artigos organizada por Pena, lançada em (2002), na qual são discutidas as questões referentes à composição biológica, histórica e cultural dos brasileiros. 
acadêmico, empresas do ramo da notícia e do entretenimento requisitaram, em alguns momentos, os testes desenvolvidos no Laboratório GENE. Uma das iniciativas que ganhou particular visibilidade foi aquela organizada pela BBC Brasil, em 2007. Intitulado "Raízes Afro-Brasileiras", o projeto era uma reprodução, in loco, de uma iniciativa similar levada a cabo nos EUA, e que envolveu personalidades "afro-americanas". ${ }^{18} \mathrm{Na}$ versão brasileira, esperava-se descobrir o percentual de contribuição africana na composição genética de nove personalidades negras, bem como as macrorregiões originárias de seus mais distantes ancestrais por parte de pai e mãe, na África: Milton Nascimento, Djavan, Seu Jorge, Neguinho da Beija-flor, Sandra de Sá, Daiane dos Santos, Obina, Ildi Silva e Frei David. O intuito do projeto, segundo sua coordenadora, Silvia Salek, ${ }^{19}$ era fomentar entre os brasileiros, a partir do exemplo dado pelas celebridades, o desejo de descobrir mais a fundo as contribuições culturais e genéticas recebidas dos africanos. ${ }^{20}$

Se havia alguma expectativa, por parte dos idealizadores do projeto, de que os testes seriam capazes de "comprovar" aquilo que se via nas peles de seus convidados e que estes incorporariam os resultados como uma prova de sua condição afrodescendente mais ou menos puro, esta foi alcançada apenas parcialmente. Isto está relacionado, em significativa medida, às prioridades metodológicas dos testes genéticos empregados. Para cada participante, os resultados da análise do DNA autossômico, do DNA mitocondrial e do cromossomo Y foram apresentados. Contudo, a ênfase na apresentação dos resultados e em sua interpretação pelos participantes

18 As análises da campanha original foram executadas pela African Ancestry.

19 Em entrevista ao Jornal da Ciência, em 19 de maio de 2007.

$20 \mathrm{Na}$ esteira deste projeto a BBC Brasil lançou um concurso no qual uma pessoa, caso vencedora, poderia fazer gratuitamente um teste de ancestralidade genética no Laboratório GENE para conferir os percentuais de DNA ameríndio, europeu e africano em sua composição biológica. Para tal os interessados deveriam enviar um formulário preenchido com seus dados, disponibilizado no sítio eletrônico, e um texto com no máximo 100 palavras explicitando o porquê de seu interesse em se submeter ao teste. 
individuais foi colocada diretamente sobre o DNA recombinante, autossômico, e sobre as proporções de diferentes ancestralidades que ele revelou. Desta forma foi priorizado a revelação do nível de miscigenação dos participantes em vez de sua descendência direta a partir do continente africano. Os resultados do teste autossômico revelaram uma proporção de ancestralidade africana entre 19,5\% (Ildi Silva) e $99,3 \%$ (Milton Nascimento). Se por um lado boa parte dos nove convidados viu nos resultados de seus respectivos testes uma (bio)revelação que confirmava ou não aquilo que eles pensavam ser, por outro as interpretações destas revelações apresentaram algumas dissonâncias.

Insatisfações e tensões geradas pelos resultados não fazem parte do escopo de testemunhos elencados nas páginas eletrônicas das empresas de testes de ancestralidade genética (Bolnick et al., 2007; Comaroff \& Comaroff, 2009; Nelson, 2008; Pálsson, 2007; Santos et al., 2010). Ao contrário, ao expressarem encantamento, surpresa, desconfiança, desdém ou mesmo raiva, os comentários que os participantes do projeto da BBC Brasil fizeram a respeito de seus testes oferecem uma vasta gama de respostas, permitindo, assim, explorar as condições sociais sob as quais um teste de ancestralidade genética se torna um agente produtor, redefinidor ou mesmo desafiador de identidades.

Daiane dos Santos foi a primeira a ter seu resultado divulgado. Por conta dos percentuais obtidos (39,7\% africana, 40,8\% europeia, 19,6\% ameríndia), a ginasta foi assinalada pela jornalista Carolina Glycério, em matéria da própria BBC Brasil, publicada em 28 de maio de 2007, como o protótipo da brasileira, por ser portadora de um perfil genético "bem equilibrado". ${ }^{21}$ Para a própria ginasta, em entrevista na mesma matéria, o teste confirmava algumas de suas suspeitas e também re-

21 Todas as entrevistas com os participantes da campanha aqui citadas foram conduzidas por Carolina Glycério entre os dias 28 e 31 de maio de 2007 e disponibilizadas na página eletrônica da BBC Brasil. 
velava uma novidade - $\mathrm{o}$ alto percentual de genes europeus: "A parte da família da minha mãe é muito estranha. Tem primo loiro, índio, ruivo, negro. É tudo misturado. É igual ao Brasil, ninguém é puro de nenhum lugar, é uma mistura de raças. (...) Essa parte européia foi a maior surpresa para mim". A despeito do resultado, ainda assim ela se encarava como uma afrodescendente, dada a cor de sua pele: "Acho que pela cor da pele. O importante é que todos somos brasileiros". Nota-se que, embora Daiane tenha ressaltado uma continuidade física com o continente africano ao evocar a cor de sua pele, sua interpretação acerca dos resultados do teste, assim como aquela da jornalista, encaixou-a firmemente dentro de uma comunidade contemporânea, brasileira, de indivíduos altamente misturados. Neste caso, mais do que tornar os brasileiros cônscios de suas origens africanas - como antecipado pela coordenadora do projeto -, os resultados do teste genético parecem ter feito uma afrodescendente declarada ter se tornado consciente de sua identidade enquanto brasileira.

Um sentimento similar de indefinição foi expresso pela atriz e modelo Ildi Silva, que viu nos resultados de seu teste $(71,3 \%$ europeia; $19,5 \%$ africana; 9,3\% ameríndia) a confirmação daquilo que ela há muito experimentava em sua vida: uma ambiguidade pronunciada, dada tanta mistura em sua própria família e a própria postura da sociedade brasileira, pautada por inúmeros matizes classificatórios, conforme se depreende de sua entrevista à BBC Brasil:

Até eu não sei como me definir. Me considero negra, mulata. Branca, não. [...] Sabia que tinha um lado holandês, mas é muita mistura. Meu pai é negro, com olho cor de mel. Minha mãe é mais clara. [...] Já tive problema com isso [mistura]. As pessoas nunca conseguiram me considerar negra. Ao mesmo tempo, tem muito trabalho que eu não faço porque sou negra.

Assim, se em alguns casos os resultados do teste genético têm a capacidade de realizar uma relativa transição na identificação a partir do continente africano para a miscigenação do Brasil, há limites 
claros para as transformações que eles são capazes de engendrar: nem mesmo um alto percentual de ancestralidade europeia levou Ildi Silva a se identificar como branca ou europeia.

Outros participantes, em contraste, colocaram uma ênfase muito maior na proporção de sua ascendência africana. Para o músico, compositor e cantor Djavan, por exemplo, os testes revelavam muito mais do que sua constituição mais ou menos misturada. Eles revelavam o que havia de mais profundo em sua alma, tão identificada com o continente africano. No seu caso ( $65 \%$ africano; $30,1 \%$ europeu; $4,9 \%$ ameríndio), destaca-se a forma como ele tomou sua composição genética como razão última de seus atributos particulares, como a musicalidade e a habilidade de falar espanhol sem nunca ter estudado a língua:

Eu sou uma pessoa do mundo, mas me sinto indubitavelmente negro em tudo. A minha música é negra, eu sou um homem negro e adoro as religiões que descendem da África. [...] Na primeira vez que eu fui à África, em 81, tomei o maior susto, quando eu pude identificar ali a raiz da minha música, porque eu tenho uma música que no início da minha carreira era muito contestada por muita gente. Diziam que era uma coisa estranha, que não tinha nem pé nem cabeça, que a minha divisão rítmica era uma coisa estranha e tal. [...] Cheguei em Angola e pude ver nitidamente onde estava a raiz disso tudo. [...] Na primeira vez que eu tive em Sevilha, fiquei chocado com a identificação. O cheiro da cidade me transportou para uma sensação que eu nunca tinha sentido. É como se eu já tivesse vivido naquele lugar por vários e vários anos na minha vida e estivesse voltando. [...] Quando eu viajo, dou entrevista em espanhol.

Tal qual Djavan, a cantora e compositora Sandra de Sá (96,7\% africana; $2,1 \%$ europeia; $1,1 \%$ ameríndia) também interpretou os resultados de seus testes como uma confirmação da sua identidade africana, bem como uma explicação para os seus talentos musicais. Como nos casos dos testemunhos dos clientes da African Ancestry e 
da Oxford Ancestors analisados anteriormente, aqui, Djavan e Sandra de Sá estabelecem uma ligação entre sua história e aspirações pessoais e o resultado de seus respectivos perfis genéticos, interpretando-os em termos positivos.

Entre os desapontados figuram o cantor e compositor Seu Jorge, o sambista Neguinho da Beija-flor e o religioso e ativista da causa negra no país Frei David. ${ }^{22}$ Em todos estes casos, o desapontamento foi relacionado, principalmente, ao fato que os resultados revelaram uma ancestralidade africana abaixo daquela esperada. Seu Jorge (85, $1 \%$ africano; $12,9 \%$ europeu; $2 \%$ ameríndio) atribuiu duas razões para o seu desalento. Gostaria de ser "100\% negro" e, em sua ótica, a presença europeia em seus genes era a prova material da barbárie que os brancos infligiram historicamente sobre os negros:

Tinha muita esperança de ser $100 \%$ negro. Se fosse, eu ia pedir uma indenização muito pesada nesse país, mas sou filho dos culpados também. [...] Miscigenação era barbárie. Não tinha isso de história de amor, era barbárie. Fico feliz em saber que parte da minha galera resistiu e compõe $85 \%$ dos meus genes. [...] Tem que ser negro para saber o que é você entrar em um ônibus, como uma pessoa normal, e ver os passageiros saltando antes do ponto, escondendo relógio, ligando para a viatura. É uma agressão muito forte. É violento.

Portanto, mais do que uma característica positiva associada a ser brasileiro, Seu Jorge interpretou a evidência genética de sua miscigenação como um testemunho duradouro da violência que marcou o encontro colonial. Sua resposta também revela a importância das idiossincrasias pessoais, em particular com relação a Djavan, para o qual mesmo uma proporção menor de ancestralidade africana permitiu-lhe estabelecer uma conexão simbólica mais forte com sua essência africana.

22 Dos nove convidados, apenas o cantor Milton Nascimento não se pronunciou publicamente sobre os resultados de seu teste ( $99,3 \%$ africano, $0,4 \%$ europeu, $0,3 \%$ ameríndio). 
Uma franca rejeição dos resultados do teste veio de Neguinho da Beija-flor. Embora seu cromossomo Y e seu DNA mitocondrial indicassem uma ancestralidade africana em suas linhagens materna e paterna, seu DNA autossômico revelou uma ancestralidade predominantemente europeia: $67,1 \%$ europeu; $31,5 \%$ africano e 1,4\% ameríndio. Neguinho da Beija-flor, um dos maiores símbolos da comunidade negra e de sua cultura no país, havia afirmado anteriormente ao teste não ter herdado qualquer coisa da Europa: "não tenho olho azul, não tenho cabelo escorrido, não tenho nada de branco aqui. Da Europa, nada!". Ele se mostrou extremamente surpreso com o resultado: "Europeu, eu?! Um negão desse! Eu vou é pela cor da pele. Se eu disser que sou $67 \%$ europeu, nego vai achar que estou de gozação". É que os resultados não somente contradiziam sua própria autoidentificação, mas também o colocavam em uma posição social incômoda dentro de uma comunidade negra politicamente sensível, onde as aspirações à brancura ou descendência europeia são, em geral, negativamente valorizadas.

Embora no caso de Frei Davi a ancestralidade Africana estivesse predominantemente em seu DNA autossômico (68,2\% africano; 30,8\% europeu; $1,0 \%$ ameríndio), tanto seu DNA mitocondrial quanto seu cromossomo $\mathrm{Y}$ indicavam uma ancestralidade máxima ameríndia. Frei David não só rejeitou os resultados eles mesmos, mas, ainda, a relevância da Genética, em geral, enquanto definidora de identidades no Brasil. Além disso, ele questionou as motivações políticas por trás delas, sugerindo que Sérgio Pena havia manipulado os resultados de modo a enfraquecer a bandeira levantada pelo movimento negro no país:

Eu me sinto muito frustrado com o trabalho, uma vez que o cerne do projeto era aprofundar a origem africana. [...] Não aceito que a ciência não tenha instrumental técnico para aprofundar a herança africana considerando que ali foi e é o berço da civilização. Ele [Sérgio Pena] simplesmente boicotou de maneira consciente o 
resultado. [...] Nunca vi nenhuma batida policial em ônibus, por exemplo, que antes de discriminar perguntasse à pessoa quantos por cento de genes afro ela teria. A discriminação e o discriminador, que tantos estragos trazem ao tecido social brasileiro, não vêem na genética os argumentos para parar de discriminar. No entanto querem que o discriminado pare de lutar por seus direitos porque "todos temos genes afro".

Os desapontamentos de Frei David e Neguinho da Beija-flor com os resultados dos testes parecem estar principalmente relacionados ao fato de eles terem sido referidos a comunidades diferentes, inesperadas e indesejadas - europeia, ameríndia, brasileira, miscigenada - mais do que à comunidade de povos com origem africana que eles haviam antecipado. Seus casos mostram a possível disjunção entre a ancestralidade genética e a identidade social, bem como entre a autoclassificação e a heteroclassificação genética e as tensões que podem emergir deste encontro.

Sérgio Pena negou ter conferido um tratamento diferenciado aos testes de Frei David, e se colocou à disposição do líder religioso para esclarecer quaisquer dúvidas sobre os resultados. Além disso, a despeito de os participantes se sentirem mais ou menos negros, e de verem revelados em seus testes características inatas provenientes dos grupos ancestrais continentais, ou mesmo de não terem apreciado sua condição miscigenada, para Pena o mais importante a ser ressaltado a partir da iniciativa era que havia um aspecto de particular abrangência a ser levado em conta. Talvez com exceção de Milton Nascimento, os perfis genômicos dos participantes refletiam o que seus estudos acadêmicos vinham apontando ao longo dos anos, inclusive os mais recentes, para a realidade brasileira: a cor da pele é um pobre indicador de ancestralidade biológica. ${ }^{23}$ Como assevera

23 Para um estudo de caso envolvendo testes de ancestralidade genômica e perspectivas identitárias no Brasil no qual são analisadas as tensões referentes a este tipo de intersecção, ver Santos et al. (2009). 
Pena, "É incrível, mas os resultados que obtivemos nas nove pessoas estudadas são um microcosmo dos resultados de nosso estudo com indivíduos autoclassificados como pretos em São Paulo". ${ }^{24}$ Assim, os testes de ancestralidade genética permitiram a Pena redefinir os indivíduos autoclassificados como negros e afrodescendentes como brasileiros típicos, misturados; uma redefinição que foi aceita por alguns (Daiane), mas enfaticamente rejeitada por outros (Neguinho da Beija Flor, Frei David). Em um deslocamento diametralmente oposto àquele proporcionado pelos testes da African Ancestry, as transformações identitárias pretendidas revelaram uma transição do específico para o genérico. ${ }^{25}$

Como a reação de Frei David sugere, contudo, sua frustração em relação ao teste não foi apenas pessoal, mas também politicamente motivada. Isto porque a mesma ênfase na miscigenação tem levado Sérgio Pena a se colocar publicamente de forma contrária ao regime de cotas raciais implantado no Brasil, principalmente no caso das Universidades públicas. Como um dos mais proeminentes advogados das políticas de ação afirmativa, Frei David se encontrava do lado oposto no debate político sobre as cotas raciais. Ao percorrermos as matérias jornalísticas disponibilizadas na página eletrônica do Laboratório GENE, vemos que não são poucas às vezes nas quais Pena critica, de algum modo, este modelo de política afirmativa, vista por ele como um mecanismo de perpetuação da crença na ideia de "raça" e, por conseguinte, do racismo.

Por exemplo, ele criticou a implantação do sistema de cotas da Universidade de Brasília da maneira seguinte: ${ }^{26}$

24 Em entrevista a Reinaldo Lopes, na página eletrônica G1, em 29 de maio de 2007.

$25 \mathrm{O}$ argumento de Pena também se aplica aos indivíduos autoclassificados brancos, cuja reivindicação de uma ancestralidade europeia exclusiva ele nega: "tirando os imigrantes de primeira e de segunda geração, é praticamente impossível que um brasileiro não carregue um pouco de ancestralidade africana ou ameríndia" (Entrevista a Carolina Glycério, em 28 de maio de 2997).

26 Em matéria de Betina Bernardes, publicada na edição de maio de 2004 da revista Primeira Leitura. Sobre o caso UnB, ver Steil (2006) e Maio \& Santos (2010). 
O mais ridículo dessa história é que lembra aqueles filmes das décadas de 30 e 40, em que nazistas mediam pessoas para saber se era judeu ou não. Há um ranço daquela eugenia, daquela antropologia muito racial, que havia no começo do século passado. [...] Raças não existem cientificamente. Raças são uma construção social, cultural. Quem tem que arcar com essa decisão [sobre cotas raciais] não é a ciência, é a sociedade e a cultura. O meu ideal, pessoalmente, seria uma sociedade não racializada. Obviamente, numa sociedade não racializada, não se pode ter cotas raciais. [...] Nosso artigo descreve a população brasileira. Qualquer decisão deve levar isso em conta.

Da mesma forma, inquirido pelo jornalista Marcelo Leite ${ }^{27}$ sobre a possibilidade de aplicação dos testes de ancestralidade genômica oferecidos por seu laboratório em políticas afirmativas, Pena foi enfático em sua negativa: "Não temos nenhuma intenção de que esse índice seja usado para avaliação individual. Seria um novo racismo".

Além disso, os resultados das pesquisas científicas de Sérgio Pena figuram, com destaque, no manifesto anticotas lançado, em 2008, por vários acadêmicos, políticos, artistas e outras figuras públicas. ${ }^{28}$ Ele mesmo foi um dos ouvidos na recente audiência pública do Supremo Tribunal Federal, sobre o tema, oportunidade na qual ele reafirmou suas proposições contrárias à ideia de "raças" e ao sistema de cotas no país. Como tal, as visões políticas de Pena e sua pesquisa científica, bem como os testes de ancestralidade oferecidos pelo Laboratório GENE, estão inseridos em uma corrente mais ampla dentro da sociedade brasileira que enfatiza e valoriza a miscigenação, contra uma tendência em direção à produção de identificações raciais e étnicas diferenciadas, expressadas com particular claridade dentro do movimento negro e do projeto das políticas de ação afirmativa. Desta feita, os testes de Frei David não somente contradizem sua

\footnotetext{
27 Em reportagem da Folha de São Paulo de 17 de dezembro de 2002.

28 http://www1.folha.uol.com.br/folha/educacao/ult305u401519.shtml.
} 
compreensão de sua própria identidade, mas também minam as construções identitárias - como negros e descendentes diretos do continente africano - sobre as quais as estratégias do movimento negro foram baseadas.

Em termos gerais, e em contraste a esta (auto) classificação identitária particularizada, o conjunto de colocações e proposições de Sérgio Pena sobre a população brasileira poderia ser mais bem caracterizada pelo título de uma canção do músico Arnaldo Antunes. Inclassificáveis, de 1996, concebe os brasileiros como inclassificáveis, exceto senão pela alcunha de miscigenados. ${ }^{29}$

\section{Conclusão - O DNA, esse deus fe(i)tiche}

Sugerimos neste ensaio que, nos três casos considerados, os testes de ancestralidade genética são vistos e apresentados como veículos de (bio)revelação através dos quais, potencialmente, transformações de si podem vir a ser operadas. O que a genética procura mostrar através destes testes é que, se por um lado, cada exemplar do Homo sapiens sobre a Terra é possuidor de um genoma só seu, por outro, este mesmo genoma também apresenta relações com os de outras pessoas, no passado e no presente. As similitudes e diferenças genéticas, no que toca à ancestralidade, funcionam como indicadores de aproximação e distanciamento, inserindo as pessoas em uma cartografia que ao mesmo tempo desafia e redefine os limites do tempo e do espaço.

Vimos como todas as três companhias oferecem a seus usuários uma experiência íntima e conceitualizada em termos sociais e de parentesco: elas estabelecem uma "comunidade genética imaginária" (Simpson 2000) da qual o cliente se torna parte. A diferença primária entre as companhias concerne aos tipos de conexões espaçotemporais que são estabelecidas e, portanto, à natureza desta comunidade a qual elas remetem seus clientes. Através de seus testes genéticos,

29 Trechos da canção, por exemplo, dizem: "Que preto, que branco, que índio o quê? // Aqui somos mestiços mulatos // Somos o que somos /Inclassificáveis". 
African Ancestry e Oxford Ancestors estabelecem ligações diretas com o passado e com partes específicas dos continentes de origem dos mais distantes ancestrais de seus clientes. A ênfase recai sobre a existência de grupos étnicos específicos que, de alguma sorte, se atualizam ao longo do tempo e do espaço, marcados muito mais pela permanência do que pela dissolução de suas características biológicas (e até mesmo não biológicas) essenciais. Em contraste, os testes do laboratório GENE engolfam seus clientes em uma comunidade contemporânea de brasileiros genéricos e misturados. Embora o ponto de partida sejam três grandes grupos populacionais claramente definidos - africanos, europeus e ameríndios -, o que é enfatizado é a diluição das características de cada um deles em uma composição biológica que é algo além da soma das partes constituintes.

Essas diferenças estão proximamente relacionadas aos tipos de metodologia que as respectivas empresas empregam. Por um lado, o DNA mitocondrial e o cromossomo $\mathrm{Y}$, não recombinantes, com os quais African Ancestry e a Oxford Ancestors trabalham, estabelecem uma descendência direta a partir do mais distante ancestral de um indivíduo através de seu pai e de sua mãe, respectivamente. Por outro lado, o DNA autossômico recombinante priorizado pelo Laboratório GENE está particularmente suscetível a revelar a miscigenação, a nível individual, dentro de uma população mestiça.

Ao menos nos casos da African Ancestry e do Laboratório GENE, as diferenças em comunidades estabelecidas também parecem estar intimamente relacionadas a contextos nacionais e históricos específicos nos quais as companhias estão inseridas, bem como aos compromissos políticos de seus proprietários. Enquanto Rick Kittles concebe os testes de ancestralidade genética com um significado de empoderamento capaz de permitir aos afro-americanos restabelecer uma ligação com seus grupos étnicos de origem e, assim, sobrepor-se aos danos ocasionados pela escravidão, Sérgio Pena enxerga como sua tarefa desracializar a sociedade brasileira revelando o 
caráter altamente misturado de sua população. Logo, as empresas não oferecem apenas transformações a nível individual, elas também objetivam realizar transformações mais abrangentes, ao nível da sociedade. Enquanto o DNA de um usuário oferece matéria prima para a experiência na qual ele ou ela embarca, a forma dessa experiência é, em parte, construída tanto pela metodologia escolhida pela empresa como por suas orientações sociopolíticas.

Em adição, as experiências individuais específicas construídas em torno dos testes de ancestralidade genética são também, parcialmente, moldadas pelas expectativas e desejos preexistentes do usuário. Clientes da African Ancestry e Oxford Ancestors explicitamente procuram por conexões diretas com o passado que ambas as companhias oferecem. Muitos brasileiros que optam por um teste de ancestralidade - incluindo alguns dos participantes dos testes patrocinados pela BBC Brasil - o fazem, precisamente, de modo a encontrar as proporções relativas de suas diferentes origens, e interpretam seus resultados a partir de uma perspectiva do que significa ser brasileiro e miscigenado. Este não era, evidentemente, o caso daquelas personalidades negras mais politicamente engajadas que participaram dos testes da BBC Brasil, porque nos planos pessoal e público de suas vidas, eles estabeleciam ligações diretas com o continente africano, e encontraram nisto sua motivação primária para participar da pesquisa. Portanto, as trajetórias pessoais dos usuários e seus posicionamentos políticos influenciam de maneira significativa sua aceitação ou rejeição de um teste de ancestralidade genética.

Nos casos aqui considerados, há de se estar preparado para enfrentar as (bio)revelações oriundas do DNA, esse deus fe(i)tiche (Latour 2002) que guarda segredos inimagináveis. Afinal, conforme nos mostram as palavras do pastor Copeland, reproduzidas no início deste trabalho, aceitar o resultado de um teste de ancestralidade genética como uma verdade sobre si mesmo parece ser, antes de qualquer coisa, um ato de fé. 


\section{Referências}

ALVES-SILVA, J. et al., 2000. The ancestry of Brazilian mtDNA lineages. American Journal of Human Genetics, 67:281-286.

ANTUNES, A., 2006. Inclassificáveis. In: O silêncio. $1 \mathrm{~cd}$. Sony/BMG Ariola. AZEVEDO, A.L. 2002. Livro conta história do brasileiro pela lente da genética. O Globo, Rio de Janeiro, 11 ago. 2002. Disponível em: http://www.laboratoriogene.com.br. Acesso em: 15 jun. 2010.

BARNES, B. \& DUPRÉ, J. Genomes and what to make of them. Chicago: University of Chicago Press, 2009.

BASTOS-RODRIGUES, L. et al. The genetic structure of human population studied through short insertion-deletion polymorphisms. Annals of Human Genetics, 70:658-665, 2006.

BBC Brasil busca ancestrais africanos dos brasileiros. Jornal da Ciência, Rio de Janeiro, 19 de maio de 2007. Disponível em: http://www.laboratoriogene. com.br. Acesso em: 25 jun. 2010.

BERNARDES, B. E se formos todos negros? Primeira Leitura, São Paulo, mai. 2004. Disponível em: http://www.laboratoriogene.com.br. Acesso em: 20 jun. 2010

BOLNICK, D.A. et al. The science and business of genetic ancestry testing. Science, 318:399-400, 2007.

. Individual ancestry inference and the reification of race as a biological phenomenon. In: KOENIG, B.A.; LEE, S.S.-J. \& RICHARDSON, S. (orgs.). Revisiting race in a genomic age. Piscataway: Rutgers University Press, 2008: 70-85.

BRANCO também pode ser afrodescendente. O Estado de São Paulo, São Paulo, 13 jan. 2002. Geral. Disponível em: http://www.laboratoriogene.com. br. Acesso em: 15 jun. 2010.

CARVALHO-SILVA, D. R. et al. The phylogeography of Brazilian Y-chromosome lineages. American Journal of Human Genetics, 68:281-286, 2001. COMAROFF, J. \& COMAROFF, J. Ethnicity, Inc. Chicago: Chicago University Press, 2009.

DAMATTA, R. Relativizando: uma introdução à antropologia social. Petrópolis: Vozes, 1984. 
DELEUZE, G. \& GUATTARI, F. Mil platôs: capitalismo e esquizofrenia. Rio de Janeiro: Editora 34, v. 3, 1996 [1980].

FOUCAULT, M. História da sexualidade I: a vontade de saber. Rio de Janeiro: Graal, 1988 [1976].

FREYRE, G. Casa grande \& senzala: formação da família brasileira sob o regime de economia patriarcal. $30^{a}$ ed. Rio de Janeiro: Record, 1995 [1933]. FULLWILEY, D. The molecularization of race: institutionalizing human difference in pharmacogenetics practice. Science as Culture, 16:1-30, 2007.

GIBBON, S. \& NOVAS, C. Introduction: biosocialities, genetics and the social sciences. In: GIBBON, S. \& NOVAS, C. (orgs.). Biosocialities, genetics and the social sciences. London: Routledge, 2008: 1-18.

GLYCÉRIO, C. 2007. "Brasil tem a cara do futuro", diz professor. BBC Brasil, São Paulo, 28 mai. 2007. Disponível em: http://www.laboratoriogene.com.br. Acesso em: 25 jun. 2010.

. Daiane dos Santos é "protótipo da brasileira". BBB Brasil, São Paulo, 28 mai. 2007. Disponível em: http://www.laboratoriogene.com.br. Acesso em: 25 jun. 2010.

"Ninguém sabe como me definir", diz atriz negra e 70\% européia. BBC Brasil, São Paulo, 29 mai. 2007. Disponível em: http://www.laboratoriogene. com.br. Acesso em: 25 jun. 2010.

. "Resultado 'bate' com o que eu sinto", diz Djavan. BBC Brasil, São Paulo, 30 mai. 2007. Disponível em: http://www.laboratoriogene.com.br. Acesso em: 25 jun. 2010.

. Seu Jorge: "se eu fosse $100 \%$ negro, lutaria por indenização". BBC Brasil, São Paulo, 30 mai. 2007. Disponível em: http://www.laboratoriogene. com.br. Acesso em: 25 jun. 2010.

$.68 \%$ africano, ativista queria mais informações sobre sua origem. $B B C$ Brasil, São Paulo, 31 mai. 2007. Disponível em: http://www.laboratoriogene. com.br. Acesso em: 25 jun. 2010.

GOMEZ, M.A. Exchanging our country marks: the transformation of African identities in the colonial and antebellum South. Chapel Hill: University of North Carolina Press, 1998.

KOENIG, B.A.; LEE, S.S.-J. \& RICHARDSON, S. Revisiting race in a genomic age. New Jersey: Rutgers University Press, 2008. 
LATOUR, B. Reflexões sobre o culto moderno dos deuses fe(i)tiches. Bauru: Edusc, 2002 [1996].

Jamais fomos modernos: ensaios de antropologia simétrica. Rio de Janeiro: Editora 34, 2005 [1994].

LEE, S.S.-J. Racial realism and the discourse of responsibility for health disparities in a genomic age. In: KOENIG, B.A.; LEE, S.S.-J. \& RICHARDSON, S. (orgs.). Revisiting race in a genomic age. Piscataway: Rutgers University Press, 2008: 342-358.

; MOUNTAIN, J. \& KOENIG, B. The meanings of race in the new genomics: implications for health disparities research. Yale Journal of Health Policy, Law and Ethics 1:33-75, 2001.

LEITE, M. Raça é só conceito social, diz DNA brasileiro. Folha de São Paulo, São Paulo, 17 dez. 2002. Folha Ciência. Disponível em: http://www.laboratoriogene.com.br. Acesso em: 15 jun. 2010.

LOPES, R. J. DNA de negros famosos retrata Brasil mestiço. G1, 29 mai. 2007. Disponível em: http://www.laboratoriogene.com.br. Acesso em: 25 jun. 2010. MAIO, M.C. \& SANTOS, R.V. Políticas de cotas raciais, os "olhos da sociedade" e os usos da antropologia: o caso do vestibular da Universidade de Brasília (UnB). In: MAIO, M.C. \& SANTOS, R.V. (orgs.). Raça como questão: história, ciência e identidades no Brasil. Rio de Janeiro: Fiocruz, 2010: 252-284.

M'CHAREK, A. The human genome diversity project: ethnography of scientific practice. Cambridge: Cambridge University Press, 2005.

NELKIN, D. \& LINDEE, M. S. The DNA mystique: the gene as cultural icon. - New York: Freeman, 1995.

NELSON, A. The factness of diaspora: the social sources of genetic genealogy. In: KOENIG, B.A.; LEE, S.S.-J. \& RICHARDSON, S. (orgs.). Revisiting race in a genomic age. Piscataway: Rutgers University Press, 2008: 253-268. O GENOMA enfim desvendado. 2009. Valor Econômico, São Paulo 29 out. 2004. Disponível em: http://www.laboratoriogene.com.br. Acesso em: 20 jun. 2010.

PÁLSSON, G. Anthropology and the new genetics. Cambridge: Cambridge University Press, 2007.

PARRA, F.C. et al. Color and genomic ancestry in Brazilians. PNAS, 100:177182, 2003. 
PENA, S. D. J. et al. Retrato molecular do Brasil. Ciência Hoje, 59:16-25, 2000. . (org.). Homo brasilis: aspectos genéticos, lingüísticos, históricos e sócio-culturais da formação do povo brasileiro. Ribeirão Preto: Funpec, 2002. O febeapá que assola o país. Jornal da FUNDEP, Belo Horizonte, jun. 2005. Primeira Pessoa. Disponível em: http://www.laboratoriogene.com. br. Acesso em: 22 jun. 2010.

Ciência, bruxas e raça. Folha de São Paulo, São Paulo, 2 ago. 2006. Opinião. Disponível em: http://www.laboratóriogene.com.br. Acesso em: 23 jun. 2010.

. Humanidade sem raças? São Paulo: Publifolha, 2008.

. et al. DNA tests probe the genomic ancestry of Brazilians. Brazilian Journal of Medical and Biological Research, 42:870-876, 2009.

. et al. The genomic ancestry of individuals from different geographical regions of Brazil is more uniform than expected. PLoS One, 6:1-9, 2011. RABINOW, P. Antropologia da razão. Rio de Janeiro: Relume-Dumará, 2002. SANTOS, R.V. \& MAIO, M.C. Race, genomics, identities and politics in Contemporary Brazil. Critique of Anthropology, 24: 347-378, 2004.

SANTOS, R.V. \& MAIO, M.C. Antropologia, raça e os dilemas das identidades na era da genômica. História, Ciências, Saúde-Manguinhos, 12:447-68, 2005. . et al. Color, race and genomic ancestry in Brazil: dialogues between Anthropology and Genetics. Current Anthropology, 50:787-819, 2009.

; BORTOLINI, M. C. \& MAIO, M. C. No fio da navalha: raça, genética e identidades. In: MAIO, M. C. \& SANTOS, R. V. (orgs.). Raça como questão: história, ciencia e identidades no Brasil. Rio de Janeiro: Editora Fiocruz, 2010: 197-217.

SIMPSON, B., 2000. Imagined genetic communities: Ethnicity and essentialism in the twenty-first century. Anthropology Today, 16: 3-6.

STEIL, C.A. (org.). Cotas raciais na universidade: um debate. Porto Alegre: UFRGS, 2006.

WINSTON, C. \& KITTLES, R. A. Psychological and ethical issues related to identity and inferring ancestry of African Americans. In: TURNER, T. R. (org.). Biological anthropology and ethics: from repatriation to genetic identity. New York: State University of New York Press, 2005: 209-229. 


\section{SOBRE OS AUTORES}

Elena Calvo-Gonzáles - Doutora em Antropologia Social pela Universidade de Manchester, Inglaterra, com pós-doutorado no Centro de Estudos Afro-Orientais e no Programa de Pós-Graduação em Ciências Sociais, ambos da Universidade Federal da Bahia (UFBA). Professora adjunta do Departamento de Sociologia da UFBA. [elenasemaga@gmail.com]

Gláucia Silva - Doutora em Antropologia Social pela Universidade de São Paulo (USP), com pós-doutorado na École de Hautes Études en Sciences Sociales (2003) e na Université Paris 1 Panthéon La Sorbonne) (bolsista CETCOPRA). Professora associada do Departamento de Antropologia e do Programa de Pós-Graduação em Antropologia da Universidade Federal Fluminense (UFF). [glaucia.o.silva@gmail.com]

Jane Felipe Beltrão - Doutora em História pela Universidade Estadual de Campinas (UNICAMP). Professora associada do Instituto de Filosofia e Ciências Humanas e do Programa de Pós-Graduação de Antropologia da Universidade Federal do Pará (UFPA). Bolsista de produtividade em pesquisa do CNPq. [jane@ufpa.br]

Luis David Castiel - Doutor em Saúde Pública pela Escola Nacional de Saúde Pública da Fundação Oswaldo Cruz (ENSP/FIOCRUZ), com pós-doutorado na Universidade de Alicante, Espanha. Pesquisador titular do Departamento de Epidemiologia e Métodos Quantitativos da ENSP/FIOCRUZ. Bolsista de produtividade em pesquisa do CNPq. [luis.castiel@ensp.fiocruz.br]

Michael Kent - Doutor em Antropologia Social pela Universidade de Manchester, Inglaterra. Pós-doutorando no Departamento de Antropologia Social da Universidade de Manchester. [michael.kent@manchester.ac.uk] 
Marko Monteiro - Doutor em Ciências Sociais pela Universidade Estadual de Campinas (UNICAMP), com pós-doutorado em Antropologia da Ciência e da Tecnologia na University of Texas em Austin (EUA). Professor associado do Departamento de Política Científica e Tecnológica do Instituto de Geociências da UNICAMP. [markosy@uol.com.br]

Naara Luna - Doutora em Antropologia pelo Programa de Pós-Graduação em Antropologia Social do Museu Nacional, Universidade Federal do Rio de Janeiro (PPGAS/UFRJ), com pós-doutorado no PPGAS/UFRJ. Professora adjunta do Instituto de Ciências Humanas e Sociais e do Programa de Pós-Graduação em Ciências Sociais da Universidade Federal Rural do Rio de Janeiro (UFRRJ). [naara_luna@ig.com.br]

Ricardo Z.N. Vêncio - Doutor em Bioinformática pela Universidade de São Paulo (USP). Professor doutor do Departamento de Computação e Matemática, Faculdade de Filosofia Ciências e Letras de Ribeirão Preto, USP. [rvencio@, usp.br]

Ricardo Ventura Santos - Doutor em Antropologia Biológica pela Indiana University (EUA), com pós-doutorado no MIT e na University of Massachusetts. Pesquisador titular na Escola Nacional de Saúde Pública da Fundação Oswaldo Cruz (ENSP/FIOCRUZ) e professor associado no Departamento de Antropologia do Museu Nacional da Universidade Federal do Rio de Janeiro (UFRJ). Bolsista de produtividade em pesquisa do CNPq. [santos@ensp.fiocruz.br]

Rosely Gomes Costa - Doutora em Ciências Sociais pelo Departamento de Antropologia Social da Universidade Estadual de Campinas (UNICAMP), com pós-doutorado na UNICAMP. Professora visitante na Universidade Estadual Julio de Mesquita (UNESP).

Sahra Gibbon - Doutora em Antropologia Social pelo Departamento de Antropologia da University College (UCL), Londres. Professora assistente do Departamento da University College, Londres. Bolsista da Wellcome Trust University Award na UCL. [s.gibbon@ucl.ac.uk] 
Sandra Caponi - Doutora em Filosofia pela Universidade Estadual de Campinas (UNICAMP), com pós-doutorado na Universidade de Paris VII e na École de Hautes Études en Sciences Sociales, Paris. Professora Associada da Universidade Federal de Santa Catarina (UFSC) e bolsista de produtividade em pesquisa de CNPq. [sandracaponi@gmail.com]

Verlan Vale Gaspar Neto - Doutorando em Antropologia Social pela Universidade Federal Fluminense (UFF). Pesquisador colaborador do Museu de Arqueologia e Etnologia Americana da Universidade Federal de Juiz de Fora (UFJF). [verlan02@yahoo.com.br] 
Este livro foi composto em Times New Roman 11/15 e impresso em papel pólen bold $70 \mathrm{~g}$ pela Imos Gráfica e Editora Ltda., no Rio de Janeiro, para as editoras Garamond e Fiocruz, no mês de junho de 2012. 